\title{
\#USGS
}

science for a changing world

Prepared in Cooperation with the South Carolina Department of Transportation

\section{Clear-Water Abutment and Contraction Scour in the Coastal Plain and Piedmont Provinces of South Carolina, 1996-99}

Water-Resources Investigations Report 03-4064 Version 1.1, August 2016 


\section{Clear-Water Abutment and Contraction Scour in the Coastal Plain and Piedmont Provinces of South Carolina, 1996-99}

By Stephen T. Benedict

U.S. Geological Survey

Water-Resources Investigations Report 03-4064

Version 1.1, August 2016

Prepared in cooperation with the

SOUTH CAROLINA DEPARTMENT OF TRANSPORTATION

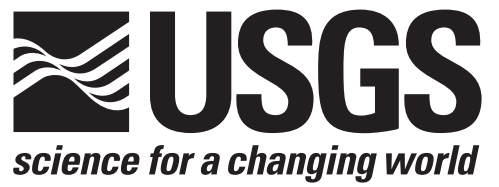




\title{
U.S. DEPARTMENT OF THE INTERIOR \\ GALE A. NORTON, Secretary
}

\author{
U.S. GEOLOGICAL SURVEY \\ Charles G. Groat, Director
}

Use of trade, product, or firm names in this publication is for descriptive purposes only and does not imply endorsement by the U.S. Geological Survey

For additional information write to:

District Chief

U.S. Geological Survey

Suite 129

720 Gracern Road

Columbia, SC 29210-7651
Copies of this report can be purchased from:

U.S. Geological Survey Branch of Information Services Box 25286

Denver, CO 80225-0286 888-ASK-USGS

Additional information about water resources in South Carolina is available on the internet at http://sc.water.usgs.gov 


\section{CONTENTS}

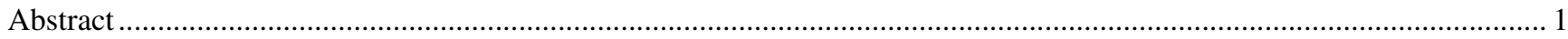

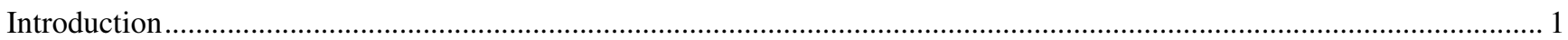

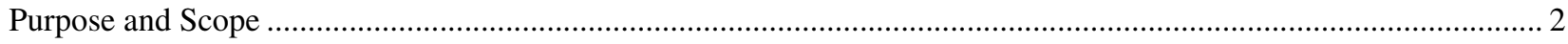

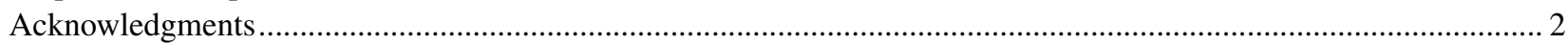

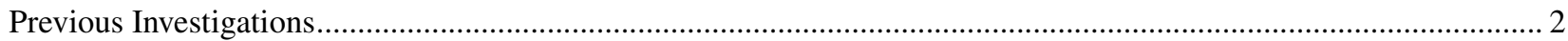

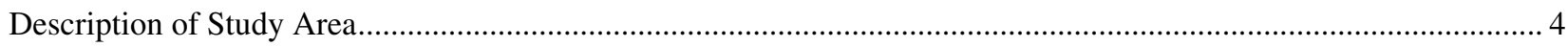

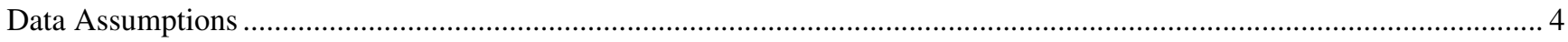

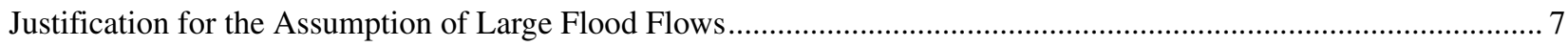

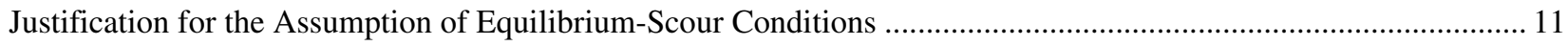

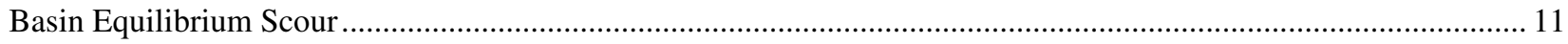

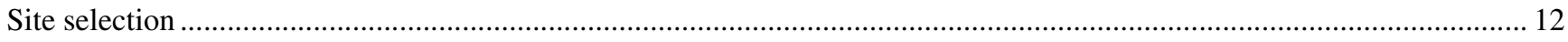

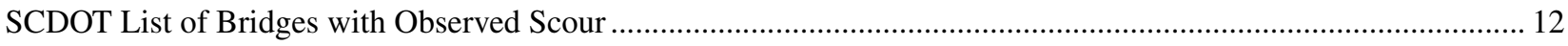

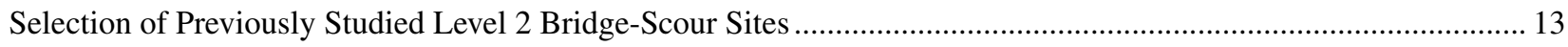

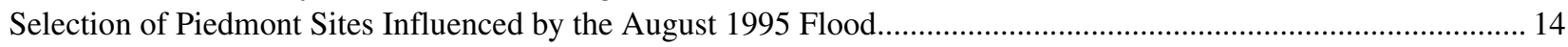

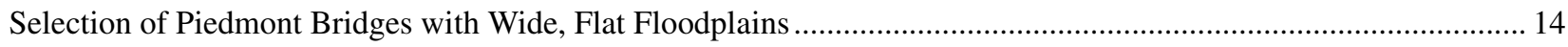

Selection of Coastal Plain Sites Influenced by the September 1999 Flood ................................................................ 14

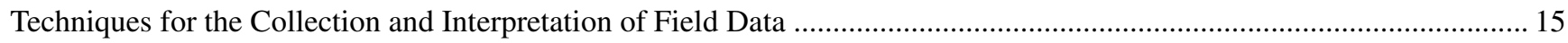

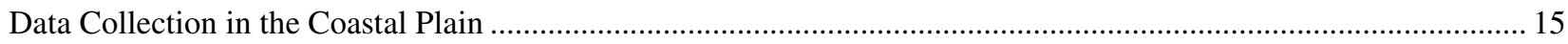

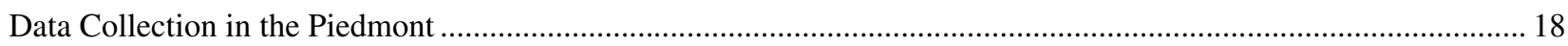

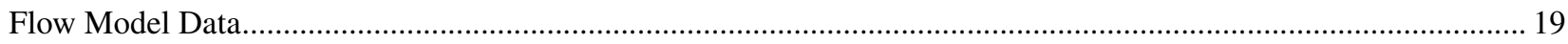

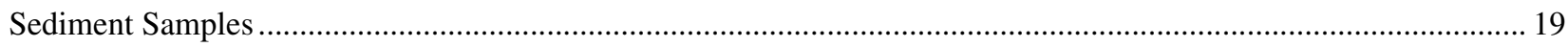

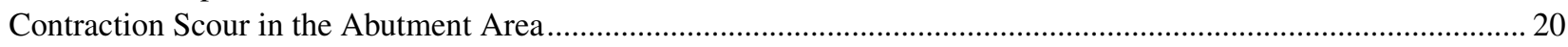

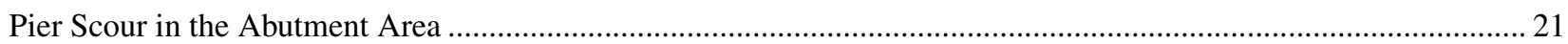

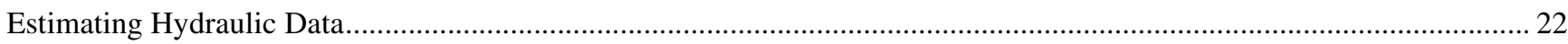

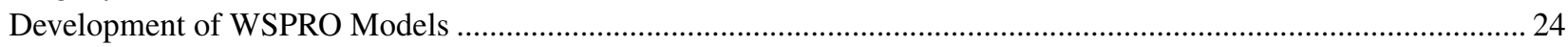

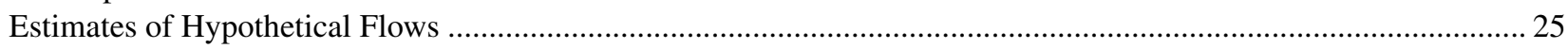

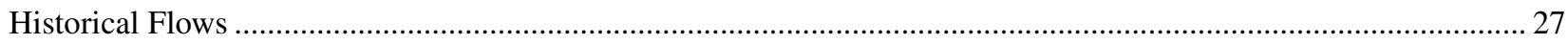

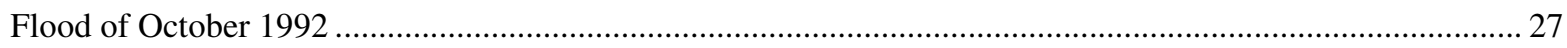

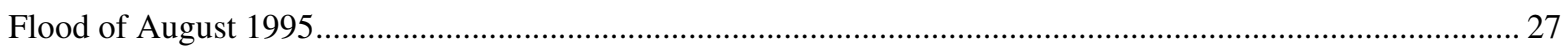

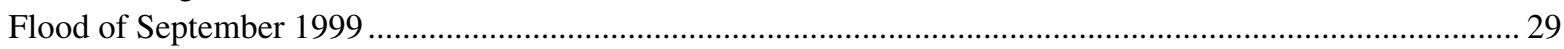

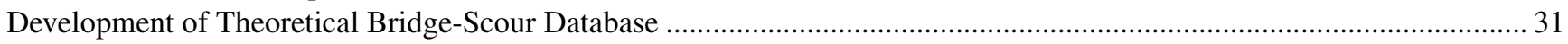

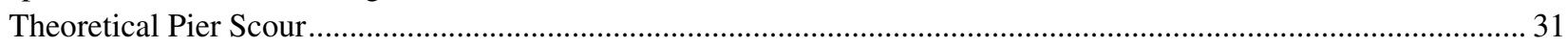

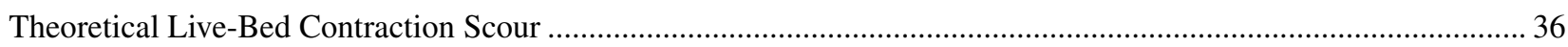

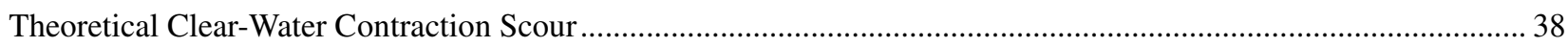

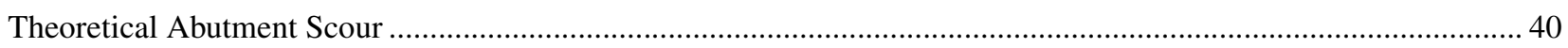

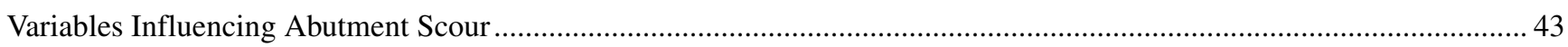

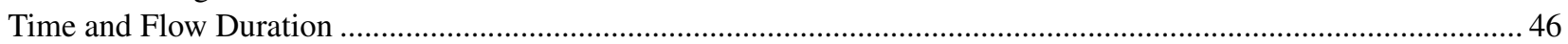

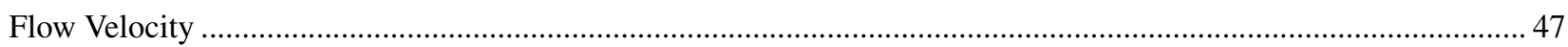

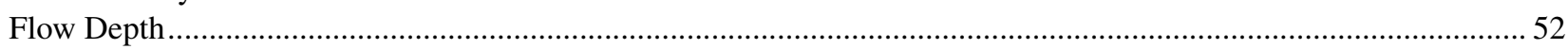

Sediment Size

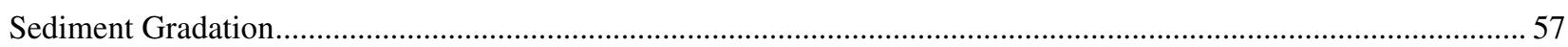

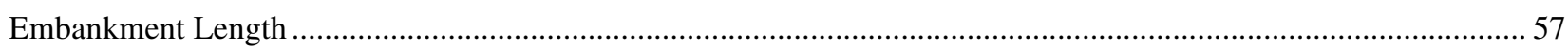

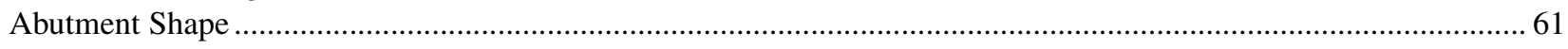

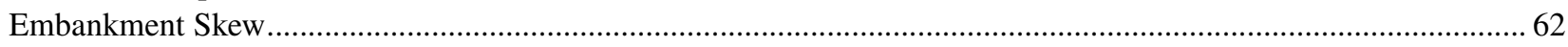

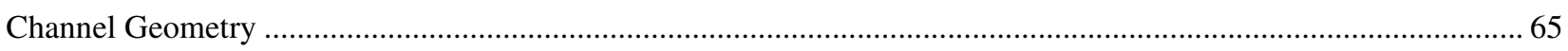

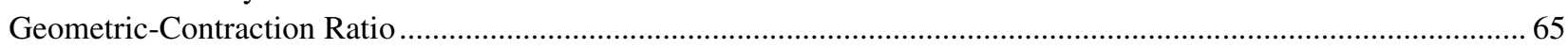

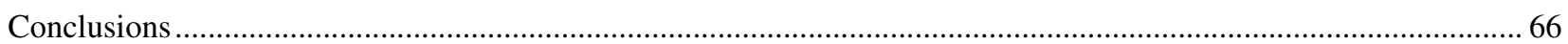




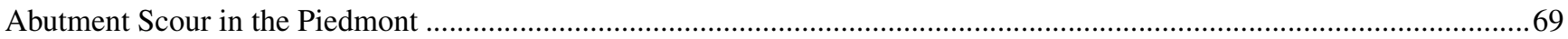

Comparison of Observed and Theoretical Abutment-Scour Depths ................................................................70

Piedmont Floodplain Geometry as an Indicator of Potential Scour ................................................................... 71

Embankment Length as an Indicator of Potential Scour ........................................................................... 71

Geometric-Contraction Ratio as an Indicator of Potential Scour .................................................................75

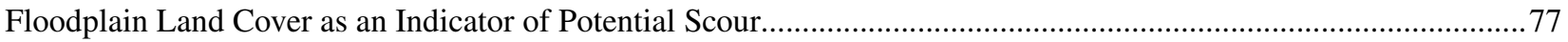

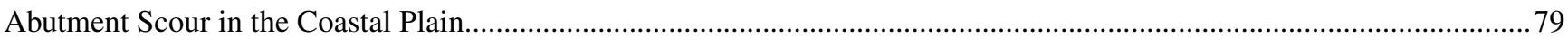

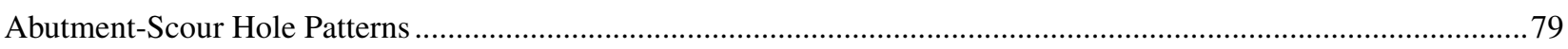

Comparison of Observed and Theoretical Abutment-Scour Depths ...................................................................8 81

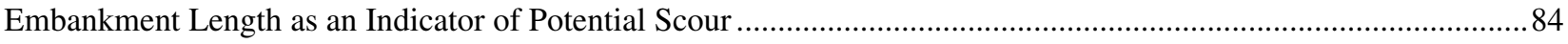

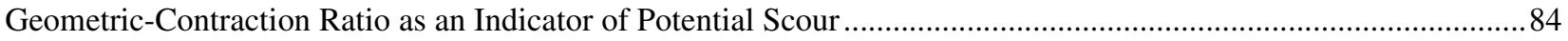

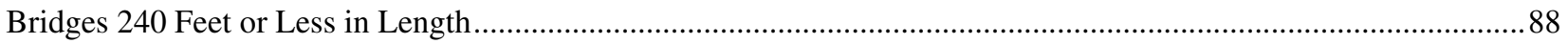

Floodplain Land Cover as an Indicator of Potential Scour............................................................................ 90

Effect of Upstream Channel Alignment on Abutment Scour..................................................................................90

Guidance for Assessing Abutment-Scour Depth Using the Envelope Curves ...........................................................91

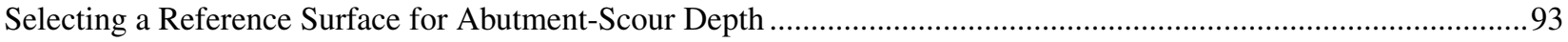

Estimating the Embankment Length and the Geometric-Contraction Ratio ....................................................93

Selecting the Appropriate Abutment-Scour Depth Envelope .....................................................................93

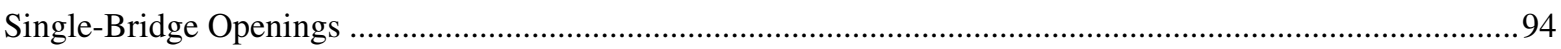

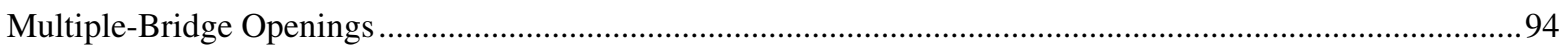

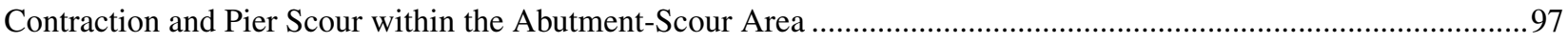

Limitations of the Abutment-Scour Depth Envelope Curves ........................................................................99

Guidance for Assessing Abutment-Scour Hole Location, Width, and Shape ................................................................99

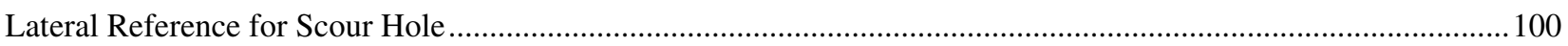

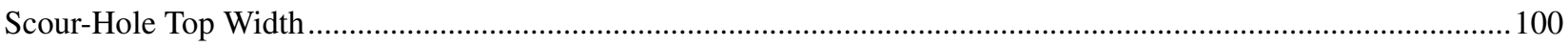

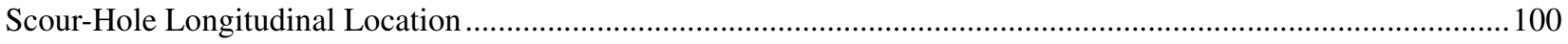

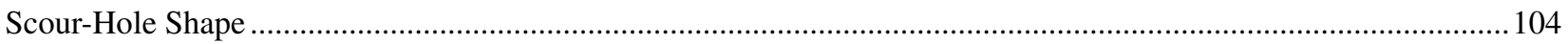

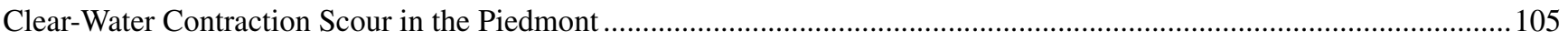

Comparison of Observed and Theoretical Contraction-Scour Depths ............................................................ 110

Geometric-Contraction Ratio as an Indicator of Potential Scour ................................................................. 110

Selecting a Reference Surface for Clear-Water Contraction Scour ................................................................. 112

Pier Scour Within Clear-Water Contraction-Scour Areas .......................................................................... 115

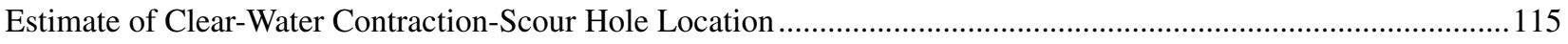

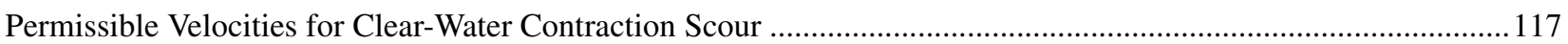

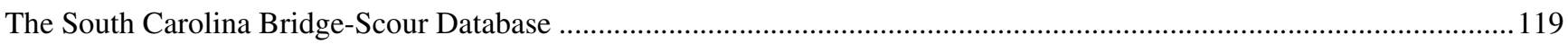

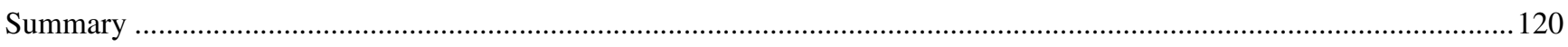

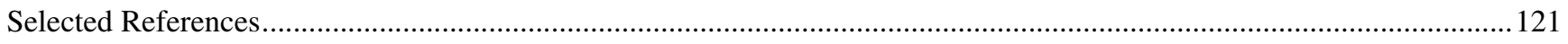

Appendix A: Explanation of Variables in the South Carolina Bridge-Scour Database .............................................123

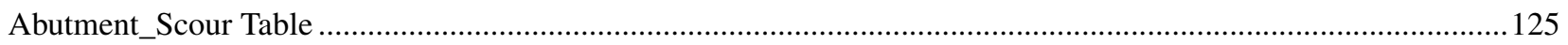

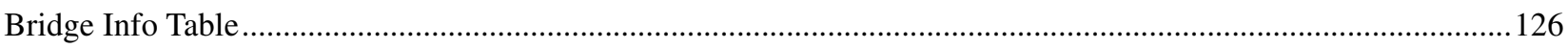

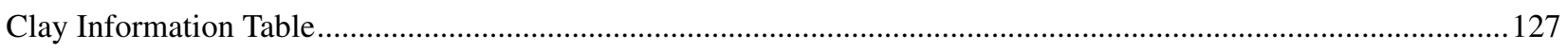

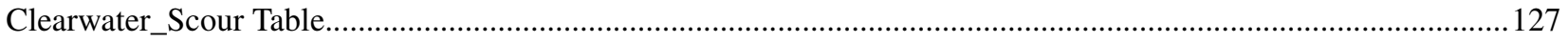

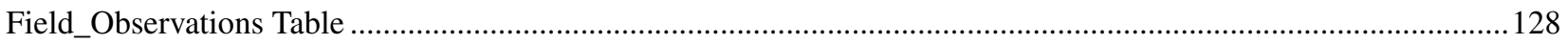

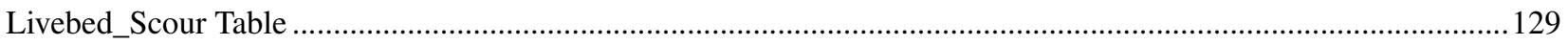

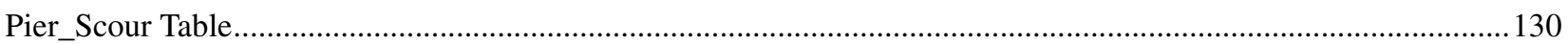

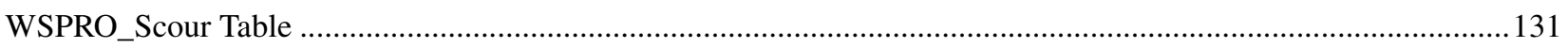

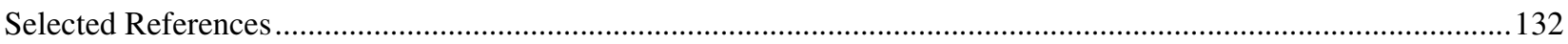

Appendix B: South Carolina Bridge-Scour Study Sites and Reference Numbers for Figures 1, 5, and 6.......................133 


\section{FIGURES}

1. Map showing location of physiographic provinces and bridge-scour study sites in South Carolina ....................... 3

2-4. Graphs showing:

2. Distribution of streambed slopes for bridge-scour study sites in the Coastal Plain and Piedmont of South Carolina

3. Distribution of drainage areas for bridge-scour study sites in the Coastal Plain and Piedmont of South Carolina 5

4. Distribution of bridge age for bridge-scour study sites in the Coastal Plain and Piedmont of South Carolina ........ 8

5. Map showing location of study bridges 40 years or older and streamflow gaging stations experiencing at least one flow equaling or exceeding 70 percent of the 100-year flow during 1956-96.....

6. Map showing location of bridge-scour study sites affected by selected historic floods in South Carolina ............. 10

7. Graph showing distribution of bridge lengths for sites discarded from the South Carolina Department of Transportation list of bridges with observed scour problems

8. Photograph of inflatable boat used to collect field data at swampy sites in the Coastal Plain of South Carolina.... 15

9. Photograph of paper-chart fathometer mounted on inflatable boat used to investigate limits of scour holes in the Coastal Plain of South Carolina

10. Map showing example of scour-hole contour plot developed from topographic-survey data at Structure 211009511400 on Interstate 95, crossing the Pee Dee River floodplain in Florence County, South Carolina, August 19, 1996

11-13. Photographs of:

11. Drive-tube coring device used to obtain sediment samples from the bottom of submerged scour holes

12. Example of sediment core collected from the bottom of a submerged scour hole using the drive-tube coring device

13. Example of minimal scour in the clayey soils of the Piedmont at Structure 47026300100 on Road S-263, crossing the Rocky River in Anderson County, South Carolina.

14. Graph showing comparison of median grain size between the original and second sediment samples.................. 20

15. Graph showing percentile plot for the maximum pier or pile width for bridge-scour study sites in the Piedmont and Coastal Plain of South Carolina.

16-18. Sketches showing:

16. Example of pile bent located at the low point of a scour hole at Structure 367008100200 on Road S-81, crossing the Enoree River in Newberry County, South Carolina, April 7, 1997.

17. Example of pile bent located on the side of a scour hole at Structure 152002100300 on U.S. Route 21, crossing Sandy Run Creek in Colleton County, South Carolina, December 18, 1996

18. Profile of pile bent.

19-21. Photographs showing:

19. Timber pile bent at Structure 194023000500 on S.C. Route 230, crossing Horne Creek in Edgefield County, South Carolina...

20. Steel H-pile bent at Structure 467072100100 on Road S-721, crossing Taylors Creek in York County, South Carolina

21. Concrete pile bent at Structure 182007800200 on U.S. Route 78, crossing Polk Swamp in Dorchester County, South Carolina.

22. Sketch showing profile of pier on spread footing and pile group

23. Photograph showing pier at Structure 262050103100 on U.S. Route 501, crossing the Waccamaw River in

Horry County, South Carolina

24. Sketch showing profile of composite bent.

25. Photograph showing composite bent at Structure 262050103200 on U.S. Route 501, crossing the Waccamaw

River in Horry County, South Carolina

26-30. Sketches showing:

26. Bridge profile with well-defined low-flow channel, showing subsections and pier identifications for theoretical pier-scour database

27. Bridge with swampy channel, showing subsection and pier identifications for theoretical pier-scour database.

28. Typical bridge with well-defined low-flow channel, showing areas of clear-water scour 
29. Typical bridge cross section for a swampy channel or floodplain relief bridge, showing area of

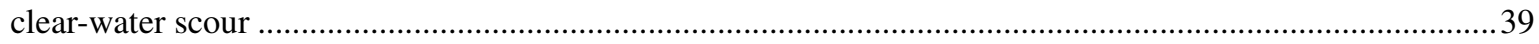

30. Plan view and profile of spill-through abutment ............................................................................4

31. Photograph of spill-through abutment at Structure 307011200100 on Road S-112, crossing the Enoree River

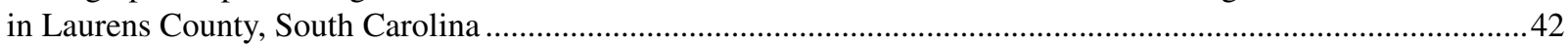

32-34. Sketches showing:

32. Plan view and profile of vertical abutment.

33. Embankment length and obstructed flow area determined by projection of the bridge cross section onto

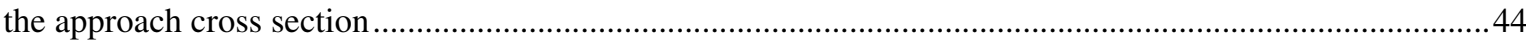

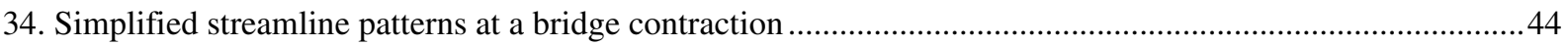

35-51. Graphs showing:

35. Comparison of the simulated 100-year-flow hydrographs for 200-square mile basins in the Piedmont and lower Coastal Plain of South Carolina

36. Comparison of hydrograph durations at 95 percent of the peak flow estimated from simulated 100-year flow hydrographs for various basin sizes in the Piedmont and lower Coastal Plain of South Carolina

37. Relation of observed clear-water abutment-scour depth and the estimated peak-flow duration for the 100-year flow at single-bridge openings in the Coastal Plain and Piedmont of South Carolina.....

38. General relation of flow intensity and abutment-scour depth normalized by embankment length based on laboratory data.

39. Relation of abutment-scour depth, normalized by embankment length, and flow intensity for laboratory data and observed data in the Piedmont and Coastal Plain of South Carolina.

40. Relation of observed clear-water abutment-scour depth and the average 100-year-flow velocity, blocked by the embankment, at single-bridge openings in the Coastal Plain and Piedmont of South Carolina ............51

41. Comparison of envelopes for the relation of observed clear-water abutment-scour depth and the average 100-year-flow velocity, blocked by the embankment, for embankment lengths of 400 feet or less in the Coastal Plain and Piedmont, and embankment lengths of 600 feet and 700 feet or less in the Coastal Plain and Piedmont of South Carolina, respectively.

42. Relation of clear-water abutment-scour depth and flow depth, normalized by embankment length, for selected laboratory data at spill-through abutments and field data collected in the Piedmont and Coastal Plain of South Carolina .....

43. Relation of observed clear-water abutment-scour depth and the 100-year-flow depth near the abutment toe for single-bridge openings in the Coastal Plain and Piedmont of South Carolina.....

44. Relation of observed clear-water abutment-scour depth and the median grain size of the original sediment sample for surface soils at single-bridge openings in the Coastal Plain and Piedmont of South Carolina.......56

45. Relation of abutment-scour depth and embankment length, normalized by flow depth, for laboratory data collected at flow intensities of 1

46. Relation of observed clear-water abutment-scour depth and the 100-year-flow embankment length, normalized by the 100-year-flow depth near the abutment toe, for the Piedmont and Coastal Plain of South Carolina with a complete horizontal axis, and a truncated horizontal axis

47. Relation of observed clear-water abutment-scour depth and the 100-year-flow embankment length for the Coastal Plain and Piedmont of South Carolina

48. Comparisons of envelopes for observed clear-water abutment-scour depth and the 100-year-flow embankment length for the Piedmont and Coastal Plain of South Carolina.....

49. Relation of abutment-scour depth correction factor and embankment skew based on data obtained from laboratory investigations where experimental tests ran for 300 minutes or less

50. Relation of observed clear-water abutment-scour depth and embankment skew for selected sites with left and (or) right abutment scour in the Piedmont and Coastal Plain of South Carolina

51. Relation of observed clear-water abutment-scour depth, for positive and negative skews, at sites with left and right abutment scour in the Piedmont and Coastal Plain of South Carolina

52. Sketch showing profile of abutment projecting into main channel ..............................................................66

53. Sketch showing profile of setback abutment commonly found in the Piedmont of South Carolina. 66 
54-58. Graphs showing:

54. Example of Coastal Plain natural cross section at Structure 212037801000 on U.S. Route 378, crossing Big Swamp in Florence County, South Carolina

55. Example of Piedmont natural cross section at Structure 444005600100 on S.C. Route 56, crossing the

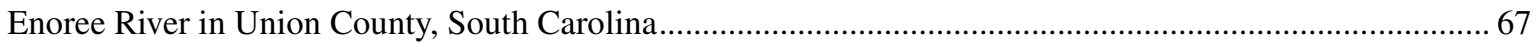

56. Relation of abutment-scour depth and geometric-contraction ratio for laboratory data.................................. 68

57. Relation of observed clear-water abutment-scour depth and the 100-year-flow geometric-contraction ratio in the Coastal Plain and Piedmont of South Carolina .....

58. Relation of observed clear-water abutment-scour depth and theoretical abutment-scour depth for the 100-year flow, and the August 1995 flood at selected sites in the Piedmont of South Carolina

59. Map showing example of wide, flat floodplain at Structure 124000901100 on S.C. Route 9, crossing

Turkey Creek in Chester County, South Carolina, and Structure 362017600400 on U.S. Route 176, crossing

Indian Creek in Newberry County, South Carolina.

60-68. Graphs showing:

60. Relation of observed clear-water abutment-scour depth and the 100-year-flow embankment length in the Piedmont of South Carolina.

61. Relation of observed clear-water abutment-scour depth and the 100-year-flow embankment length with identification of the 1995 flood sites in the Piedmont of South Carolina.

62. Relation of theoretical 100-year-flow abutment-scour depth and embankment length compared with the envelope of observed abutment scour for selected sites in the Piedmont of South Carolina...

63. Relation of observed clear-water abutment-scour depth and the 100-year-flow geometric-contraction

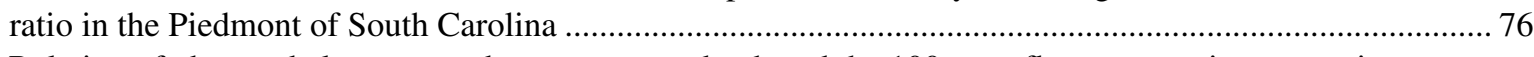

64. Relation of observed clear-water abutment-scour depth and the 100-year-flow geometric-contraction ratio with identification of the 1995 flood sites in the Piedmont of South Carolina

65. Relation of theoretical 100-year-flow abutment-scour depth and the 100-year-flow geometric-contraction ratio compared with the envelope of observed data in the Piedmont of South Carolina

66. Relation of observed clear-water abutment-scour depth and the 100-year-flow embankment length with the identification of sites with lowered floodplain flow resistance for the Piedmont of South Carolina........ 78

67. Percentile of observed clear-water abutment-scour depth in the Piedmont and Coastal Plain of South Carolina

68. Percentile of the 100-year-flow floodplain width for study sites in the Piedmont and Coastal Plain of South Carolina

69. Sketch showing example of single scour hole at shorter bridges in the Coastal Plain, as shown at Structure

212030100100 on U.S. Route 301, crossing Douglas Swamp in Florence County, South Carolina, July 31, 1996...... 81

70. Sketch showing example of separate left and right abutment-scour holes at longer bridges in the Coastal Plain, as shown at Structure 277008700100 on Road S-87, crossing the Coosawhatchie River in Jasper County,

South Carolina, November 12, 1997

71-78. Graphs showing:

71. Relation of observed clear-water abutment-scour depth with theoretical abutment-scour depth for the 100-year flow, and the maximum historic flow at selected sites in the Coastal Plain of South Carolina......... 83

72. Relation of observed clear-water abutment-scour depth and the 100-year-flow embankment length for the Coastal Plain of South Carolina with a complete horizontal axis and a truncated horizontal axis.

73. Relation of observed clear-water abutment-scour depth and the 100-year-flow embankment length identifying the 1992 and 1999 flood sites in the Coastal Plain of South Carolina.....

74. Relation of theoretical 100-year-flow abutment-scour depth and the 100-year-flow embankment length compared with the envelope of observed abutment scour for selected sites in the Coastal Plain of South Carolina

75. Relation of observed clear-water abutment-scour depth and the 100-year-flow geometric-contraction ratio for the Coastal Plain of South Carolina

76. Relation of observed clear-water abutment-scour depth and the 100-year-flow geometric-contraction ratio identifying sites with known maximum historic flows in the Coastal Plain of South Carolina

77. Relation of theoretical 100-year-flow abutment-scour depth and the 100-year-flow geometric-contraction ratio compared with the envelope of observed abutment scour in the Coastal Plain of South Carolina 88 
78. Relation of observed clear-water abutment-scour depth and the 100-year-flow embankment length identifying sites with bridge lengths of 240 feet or less and single scour holes in the Coastal Plain of South Carolina with a complete horizontal axis and a truncated horizontal axis

79. Sketch showing plan view of channel bends and resulting scour hole at Structure 304007200500

on S.C. Route 72, crossing the Little River in Laurens County, South Carolina

80. Aerial photograph of severe meander on the Waccamaw River at Structure 264000920500 on S.C. Route 9 in Horry County, South Carolina .....

81. Photograph of scour hole at left abutment viewed from downstream at Structure 264000920500

on S.C. Route 9, crossing the Waccamaw River in Horry County, South Carolina..

82-86. Graphs showing:

82. Relation of observed clear-water abutment-scour depth and the 100-year-flow embankment length with the identification of multiple-bridge openings for the Piedmont of South Carolina......

83. Relation of observed clear-water abutment-scour depth and 100-year-flow geometric-contraction ratio with the identification of multiple-bridge openings for the Piedmont of South Carolina

84. Relation of observed clear-water abutment-scour depth and the 100-year-flow embankment length with the identification of multiple-bridge openings in the Coastal Plain of South Carolina .....

85. Relation of observed clear-water abutment-scour depth and the 100-year-flow geometric-contraction ratio with the identification of multiple-bridge openings in the Coastal Plain of South Carolina

86. Relation of observed clear-water abutment-scour depth and the 100-year-flow embankment length identifying sites with a pier or pile bent located at the low point of the scour hole for the Coastal Plain, and Piedmont of South Carolina

87. Sketch showing plan view of reference for estimating the width and lateral location of an abutment-scour hole .......101 88-90. Graphs showing:

88. Lateral location of scour-hole bank in reference to the abutment toe for observed abutment scour in the Piedmont and Coastal Plain of South Carolina

89. Relation of abutment-scour-hole top width and abutment-scour depth at bridges greater than 240 feet in length, and swampy and floodplain relief bridges, 240 feet or less in length in the Piedmont and Coastal Plain of South Carolina

90. Relation of longitudinal location for the low point of the abutment-scour hole and the 100-year-flow top width at the bridge for shallow and deep scour holes in the Piedmont of South Carolina, and sites in the Coastal Plain of South Carolina

91. Sketch showing example of scour-hole low point located upstream at Structure 367029900100 on

Road S-299, crossing Cannons Creek in Newberry County, South Carolina, November 24, 1997.

92. Sketch showing example of scour-hole low point located downstream at Structure 344004100800

on S.C. Route 41, crossing Maiden Down Swamp in Marion County, South Carolina, December 3, 1996.

93. Graph showing ground line of existing scour hole compared with the shape of a trapezoid and rectangle .......... 106

94. Sketch showing profile of overbank area for bridges with setback abutments ...................................................106

95. Sketch showing plan view of areas of clear-water abutment and contraction scour ............................................ 107

96. Map showing example of abutment- and clear-water contraction-scour areas at Structure 367008100200

on Road S-81, crossing the Enoree River in Newberry County, South Carolina .................................................. 108

97-100. Photographs showing:

97. Right abutment-scour hole as viewed from downstream at Structure 367008100200 on Road S-81, crossing the Enoree River in Newberry County, South Carolina

98. Clear-water contraction scour on the right overbank as viewed from the left at Structure 367008100200 on Road S-81, crossing the Enoree River in Newberry County, South Carolina...

99. Example of shallow clear-water contraction scour at Structure 464032200300 on S.C. Route 322, crossing Fishing Creek in York County, South Carolina.

100. Example of shallow clear-water contraction scour at Structure 114000500200 on S.C. Route 5, crossing Buffalo Creek in Cherokee County, South Carolina.

101-104. Graphs showing relation of:

101. Observed and theoretical clear-water contraction-scour depth for the 100-year flow, and the August 1995 flood at selected sites in the Piedmont of South Carolina.....

102. Observed clear-water contraction-scour depth and the 100-year-flow geometric-contraction ratio in the Piedmont of South Carolina 
103. Observed clear-water contraction-scour depth and the 100-year-flow geometric-contraction ratio identifying sites for the 1995 flood in the Piedmont of South Carolina

104. Theoretical 100-year-flow clear-water contraction-scour depth and the 100-year-flow geometric-contraction ratio compared with the envelope of observed data in the Piedmont of South Carolina

105. Photograph of the erosion of bed material from around piles caused by bank widening from the August 1995 flood at Structure 307026300100 on Road S-263, crossing the Enoree River in Laurens County, South Carolina

106. Graph showing relation of longitudinal location for the low point of the clear-water contraction-scour hole and observed contraction-scour depth in the Piedmont of South Carolina

107. Graph showing relation of observed clear-water contraction scour depth and the average overbank velocity for the 100-year flow in the Piedmont of South Carolina

Tables

1. Percent risk for the occurrence of the 25-year recurrence-interval flow for selected bridge ages ................................ 7

2. Bridge-scour study sites influenced by the high-flow region in the Piedmont of South Carolina................................. 26

3. Bridge-scour study sites with impervious area exceeding 10 percent of the drainage-basin area .................................27

4. Estimated peak flows from the October 1992 flood at bridge-scour study sites in the lower Coastal Plain of South Carolina

5. Estimated peak flows at selected U.S. Geological Survey gaging stations and ungaged sites for the August 1995 flood along the Reedy, South Tyger, and Enoree Rivers in South Carolina 28

6. Estimated peak flows at bridge-scour study sites for the August 1995 flood in the Piedmont of South Carolina

7. Estimated peak flows at selected U.S. Geological Survey gaging stations for the September 1999 flood along the Waccamaw River in North Carolina and South Carolina.....

8. Estimated maximum historic flows for bridge-scour study sites along the Waccamaw, Pee Dee, and Little Pee Dee Rivers in South Carolina

9. Estimated maximum historic flows at selected U.S. Geological Survey gaging stations along the Pee Dee and Little Pee Dee Rivers in South Carolina 30

10. Range of selected parameters for 100 observations of clear-water abutment scour collected at 65 bridges in the Piedmont of South Carolina

11. Field observations excluded from the development of the embankment-length envelope curve (figure 60) for the Piedmont of South Carolina

12. The effect of changing floodplain flow resistance exemplified by model data at Structure 367029900100 on Road S-299, crossing Cannons Creek in Newberry County, South Carolina.

13. Range of selected parameters for 109 observations of clear-water abutment scour collected at 81 bridges in the Coastal Plain of South Carolina

14. Range of selected parameters for 76 observations of clear-water contraction scour collected at 53 bridges in the Piedmont of South Carolina 112

15. Pre- and post-flood channel top widths for the 1995 flood at selected sites along the Enoree River in the Piedmont of South Carolina 
CONVERSION FACTORS, TEMPERATURE, VERTICAL DATUM, ABBREVIATIONS, AND ACRONYMS

\begin{tabular}{rcl} 
Multiply & By & \multicolumn{1}{c}{ To obtain } \\
& Length & \\
inch (in.) & 25.4 & millimeter \\
foot (ft) & 0.3048 & meter \\
mile (mi) & 1.609 & kilometer \\
& Area & \\
square mile $\left(\mathrm{mi}^{2}\right)$ & 2.590 & square kilometer \\
& Volume & \\
cubic foot $\left(\mathrm{ft}^{3}\right)$ & 0.02832 & cubic meter \\
& Flow Rate & \\
\hline cubic foot per second $\left(\mathrm{ft}^{3} / \mathrm{s}\right)$ & 0.02832 & cubic meter per second \\
foot per second $(\mathrm{ft} / \mathrm{s})$ & 0.3048 & meter per second \\
\hline & &
\end{tabular}

Equations for temperature conversion between degrees Celsius $\left({ }^{\circ} \mathrm{C}\right)$ and degrees Fahrenheit $\left({ }^{\circ} \mathrm{F}\right)$ :

$$
\begin{gathered}
{ }^{\circ} \mathrm{C}=5 / 9\left({ }^{\circ} \mathrm{F}-32\right) \\
{ }^{\circ} \mathrm{F}=\left(1.8 \mathrm{x}{ }^{\circ} \mathrm{C}\right)+32
\end{gathered}
$$

Vertical coordinate information is referenced to the North American Vertical Datum of 1988 (NAVD 88); horizontal coordinate information is referenced to the North American Datum of 1927 (NAD 27).

\section{ACRONYMS AND ABBREVIATIONS}

\begin{tabular}{rll}
\hline FHWA & Federal Highway Administration \\
HEC & Hydraulic Engineering Circular \\
HIRE & Highways in the River Environment \\
PVC & polyvinyl chloride \\
SCBSD & South Carolina Bridge Scour Database \\
SCDOT & South Carolina Department of Transportation \\
USGS & U.S. Geological Survey \\
WSPRO & water-surface profile \\
mm & millimeter \\
$<$ & less than \\
$\leq$ & less than or equal to \\
$>$ & greater than \\
$\geq$ & greater than or equal to
\end{tabular}




\title{
Clear-Water Abutment and Contraction Scour in the Coastal Plain and Piedmont Provinces of South Carolina, 1996-99
}

\author{
By Stephen T. Benedict
}

\section{ABSTRACT}

The U.S. Geological Survey, in cooperation with the South Carolina Department of Transportation, collected observations of clear-water abutment and contraction scour at 146 bridges in the Coastal Plain and Piedmont of South Carolina. Scour depths ranged from 0 to 23.6 feet. Theoretical scour depths were computed at each bridge and compared with observed scour. This comparison showed that theoretical scour depths, in general, exceeded the observed scour depths and often were excessive. A comparison of field data with dimensionless relations for laboratory data showed that the range of dimensionless variables used in laboratory investigations was outside of the range for field data in South Carolina, suggesting laboratory relations may not be applicable to field conditions in South Carolina. Variables determined to be important in developing scour within laboratory studies were investigated to understand their influence within the South Carolina field data, and many of these variables appeared to be insignificant under field conditions found in South Carolina. The strongest explanatory variables were embankment length, geometric-contraction ratio, approach velocity, and soil cohesion. Envelope curves developed with the field data are useful tools for assessing reasonable ranges of scour depth in South Carolina. These tools are simple to apply and are an improvement over the current methods for predicting theoretical scour.
Data from this study have been compiled into a database that includes photographs, figures, observed scour depths, theoretical scour depths, limited basin characteristics, limited soil data, and theoretical hydraulic data. The database can be used to compare studied sites with unstudied sites to assess the potential for scour at the unstudied sites. In addition, the database can be used to assess the performance of various theoretical methods for predicting clear-water abutment and contraction scour.

\section{INTRODUCTION}

In the late 1980's, bridge scour caused the catastrophic failures of the Schoharie Creek Bridge in New York State and the Hatchie River Bridge in Tennessee, resulting in the loss of life. These tragic events brought the issue of bridge scour to the forefront of the highway engineering community. To address the issue, the Federal Highway Administration (FHWA) published Hydraulic Engineering Circulars (HEC) 18 and 20 (Richardson and others, 1991; Lagasse and others, 1991) to provide state-of-the-knowledge guidance on evaluating theoretical scour at bridges. In addition to these publications, the FHWA initiated a national program to evaluate the susceptibility of existing bridges to scour. This program encompassed all bridges under state jurisdiction and delegated the responsibility of the evaluations to each state. 
To comply with this program, the South Carolina Department of Transportation (SCDOT), conducted level 1 assessments at 3,506 bridges and made detailed level 2 bridge-scour studies at approximately 700 bridges, using the methods presented in HEC-18 (Richardson and others, 1991; Richardson and others, 1993). The level 2 studies included estimates of theoretical scour caused by the 100- and 500-year flows using methods presented in HEC-18. These estimates indicated that the theoretical scour depths were often much greater than the scour depths observed in the field. These results, in conjunction with the lack of field verification of the HEC-18 laboratory-derived equations, prompted the SCDOT to question the applicability of the HEC-18 methods to South Carolina streams.

To address the excessive estimates of clear-water contraction and abutment scour in the cohesive soils of the Piedmont, the U.S. Geological Survey (USGS) in cooperation with the SCDOT, initiated a study in May 1996 to investigate clear-water contraction and abutment scour at bridges in South Carolina. The general objectives of the study were to (1) collect field observations of scour, (2) use the data to assess the HEC-18 methods for predicting theoretical scour, and (3) if possible, improve the theoretical scour-prediction methods for streams in South Carolina. The scope of the investigation was limited to clear-water contraction and abutment scour in the sandy soils of Coastal Plain swamps and in the cohesive overbank soils of Piedmont streams. These regions (fig. 1) are characterized by thick floodplain vegetation that promotes conditions for clear-water scour. In addition, large depths of scour are known to frequently occur in the sandy soils of the Coastal Plain in contrast to infrequent occurrences in the cohesive soils of the Piedmont. This contrast of soil types and occurrences of scour between the regions should provide valuable insights into the scour processes for South Carolina streams.

\section{Purpose and Scope}

The purpose of this report is to describe (1) techniques used to collect clear-water contraction and abutment-scour data at 146 bridges in the Coastal Plain and Piedmont Provinces of South Carolina, (2) a comparison of theoretical clear-water contraction and abutment-scour depths with observed scour depths, (3) selected relations within the field data, and (4) envelope curves that may be used to estimate ranges of anticipated clear-water contraction and abutment scour at bridges in the Coastal Plain and Piedmont Provinces of South Carolina. In addition, a compilation of the data developed for each bridge site is provided on a compact disc (CD). This compilation includes, photographs, figures, observed scour depths, theoretical scour depths, limited basin characteristics, limited soil data, and theoretical hydraulic data, which can be viewed using Microsoft Access.

\section{Acknowledgments}

The author gratefully acknowledges the assistance and support of William H. Hulbert, SCDOT (retired), and C. Lamar Sanders, Jr., (USGS). The expertise of both men in the area of stream and bridge hydraulics helped form the concept for this study and provided valuable direction throughout the investigation. The author also gratefully acknowledges the dedicated work of Andy W. Caldwell (USGS), in assisting with the collection and analysis of the field data used in this report.

\section{Previous Investigations}

The USGS, in cooperation with the SCDOT, investigated scour in South Carolina in two previous studies. The first investigation, level 1 bridge-scour assessment, was conducted during 1990-92 when limited structural, hydraulic, geomorphic and vegetative data at 3,506 bridges and culverts were collected (Hurley, 1996). This information was largely qualitative in nature and was used to develop observed- and potential-scour indexes at each site. The observed scour index provides a relative indicator of the amount of scour observed at the site during the site visit. The potential-scour index provides a relative indicator of the potential for scour at the site, based on site-specific data. These indexes, along with other variables, were used by the SCDOT to select sites that required additional investigation. Approximately 700 sites were selected for more detailed level 2 studies, in which theoretical scour was estimated using methods presented in HEC-18 (Richardson and others, 1991).

The second cooperative investigation, conducted during 1992-95, included level 2 studies at 293 bridges selected from the first study. A detailed study was conducted at each bridge site including (1) estimates of the 100- and 500-year recurrence-interval watersurface profiles using the Water-Surface Profile (WSPRO) model (Shearman, 1990), (2) computation of 


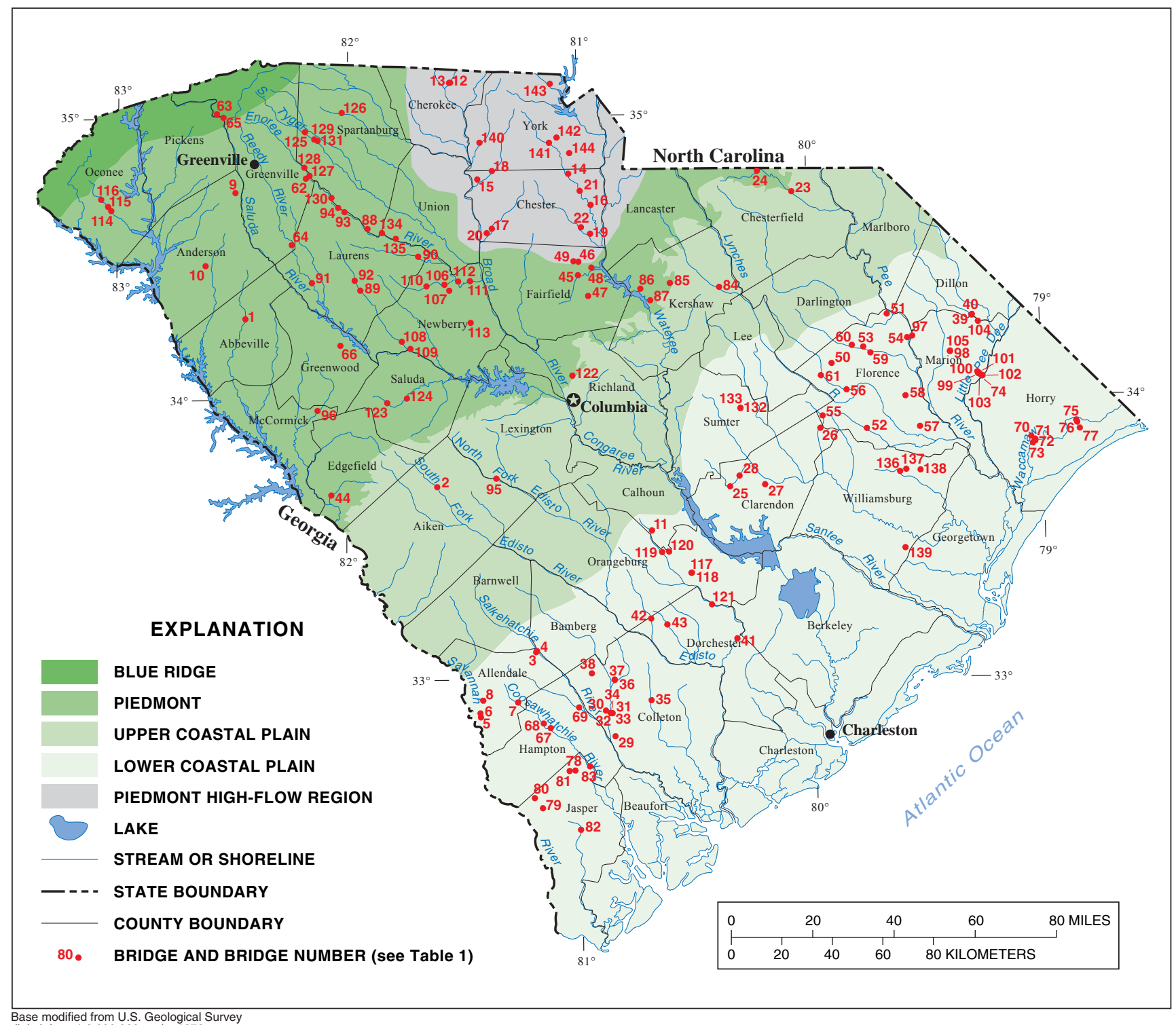

Base modified from U.S. Geological Survey
digital data, $1: 2,000,000$ scale, 1972

Figure 1. Location of physiographic provinces and bridge-scour study sites in South Carolina. (Refer to appendix B at back of report to identify bridge with corresponding number.)

theoretical scour for the 100- and 500-year flows using methods in HEC-18 (Richardson and others, 1991, 1993), and (3) comparison of theoretical scour depths to bridge foundations to provide an indicator of the vulnerability of the bridge to failure. This information is used by the SCDOT to assist in determining if additional studies and (or) remedial action are required to protect a bridge from the threat of scour.

The level 1 and level 2 bridge-scour studies gave a qualitative overview of scour, which helped form general concepts of the type, magnitude, and frequency of scour throughout South Carolina. In addition, the level 2 bridge-scour study provided evidence of the apparent discrepancy between the theoretical and observed scour in the cohesive soils of the Piedmont. This information was helpful in developing the approach for this investigation, to study clear-water scour in the Piedmont, where scour generally is insignificant, and in the Coastal Plain, where larger magnitudes of scour frequently occur. This study used 105 of the level 2 bridge-scour sites, from the previous investigations. These sites, with previously developed WSPRO models (Shearman, 1990), reduced the time and cost associated with developing such models. 


\section{Description of Study Area}

South Carolina has an area of about $31,100 \mathrm{mi}^{2}$ and is divided into three physiographic provinces: the Blue Ridge, Piedmont, and Coastal Plain, with the Coastal Plain being divided into an upper and lower region (fig. 1). The study area includes most of South Carolina, but generally excludes the Blue Ridge Province and the tidally influenced area of the lower Coastal Plain.

The Piedmont physiographic province covers approximately 35 percent of South Carolina and lies between the Blue Ridge and Coastal Plain Provinces (fig. 1). Land-surface elevations range from about $400 \mathrm{ft}$ near the Fall Line (Coastal Plain boundary) to roughly $1,000 \mathrm{ft}$ at the Blue Ridge boundary. The general topography includes rolling hills, elongated ridges, and moderately deep to shallow valleys. The drainage patterns are well developed with well-defined channels and densely vegetated floodplains. Stream slopes in the Piedmont range from approximately 0.00015 to $0.0100 \mathrm{ft} / \mathrm{ft}$. The geology of the Piedmont consists of fractured crystalline rock overlain by moderately to poorly permeable silty clay loams. Alluvial deposits along the valley floors consist of clay, silt, and sand, and form varying degrees of cohesive soils (Guimaraes and Bohman, 1992). The cohesive soils, typically found on Piedmont floodplains, provide some resistance to scour and are believed to be an important factor in minimizing scour depths in this region. The thick floodplain vegetation significantly impedes sediment transport, promoting clear-water scour conditions on the floodplain.

Limited data indicate that peak flows are higher in the northeastern region of the Piedmont than in the western region (Guimaraes and Bohman, 1992). This area is designated as the Piedmont high-flow region (fig. 1). In this study, 65 bridge sites in the Piedmont physiographic province (21 within or influenced by the high-flow region) were surveyed for clear-water contraction and abutment scour. Stream slopes and drainage areas for these sites range from 0.00015 to $0.00290 \mathrm{ft} / \mathrm{ft}$ (fig. 2) and 11.0 to $1,620 \mathrm{mi}^{2}$ (fig. 3), respectively. (Two sites within the Blue Ridge physiographic province (fig. 1) have characteristics similar to Piedmont streams and, therefore, were classified as Piedmont sites.)

The upper Coastal Plain is bounded by the Piedmont and lower Coastal Plain, and covers approximately 20 percent of the State (fig. 1). The general topography in the upper Coastal Plain consists of rounded hills with gradual slopes, and land-surface elevations that range from less than $200 \mathrm{ft}$ to more than $700 \mathrm{ft}$. The geology consists primarily of sedimentary rocks composed of layers of sand, silt, clay, and gravel underlain by igneous rocks (Zalants, 1990). A shallow surface layer of permeable sandy soils is common. Low-flow channels bounded by densely vegetated floodplains characterize upper Coastal Plain streams. Stream slopes are moderate, ranging from approximately 0.0005 to $0.0040 \mathrm{ft} / \mathrm{ft}$ (Guimaraes and Bohman, 1992). In this study, four bridge sites in the upper Coastal Plain were surveyed for clear-water contraction and abutment scour.

The lower Coastal Plain covers about 43 percent of the State (fig. 1). The topographic relief in the lower Coastal Plain is less pronounced than that of the upper Coastal Plain, and land-surface elevations range from sea level at the coast to nearly $200 \mathrm{ft}$ at the boundary with the upper Coastal Plain. The geology of the lower Coastal Plain consists of loosely consolidated sedimentary rocks of sand, silt, clay, and gravel overlain by permeable sandy soils (Zalants, 1991). Stream slopes range from approximately 0.0001 to $0.0040 \mathrm{ft} / \mathrm{ft}$ (fig. 2), and streamflow patterns are tidally influenced near the coast (Guimaraes and Bohman, 1992).

Although large rivers flow within well-defined channels in the lower Coastal Plain, the area is noted for its numerous swamps, which have wide, densely vegetated floodplains that are drained by a network of shallow, poorly defined channels. Because of the thick vegetation, the shallow channels have large root masses at or just below the ground surface. These root masses significantly impede the transport of bed sediments, thereby promoting clear-water scour conditions at bridge contractions. In this study, 77 bridge sites in the lower Coastal Plain were surveyed for clear-water contraction and abutment scour; 68 of these sites are in swamps. Stream slopes and drainage areas for the 81 sites in the upper and lower Coastal Plain range from 0.00007 to $0.002400 \mathrm{ft} / \mathrm{ft}$ (fig. 2) and 6.0 to $8,830 \mathrm{mi}^{2}$ (fig. 3), respectively.

\section{DATA ASSUMPTIONS}

Live-bed scour occurs at a bridge when bed sediments are transported into the area of scour. Under these conditions, sediments will be deposited into the scoured area as flood flows recede, and the scoured area will be totally or partially obscured by the infill. In contrast, clear-water scour occurs at a bridge when 


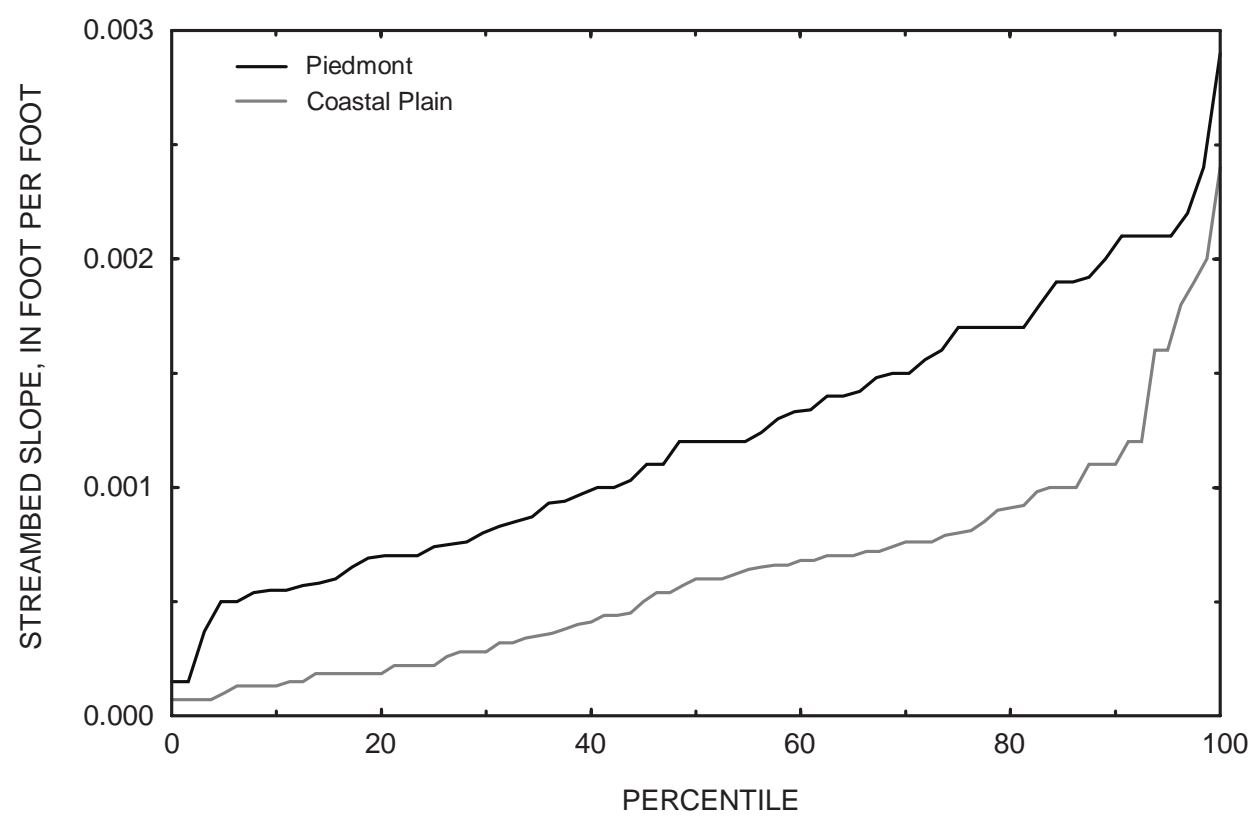

Figure 2. Distribution of streambed slopes for bridge-scour study sites in the Coastal Plain and Piedmont of South Carolina.

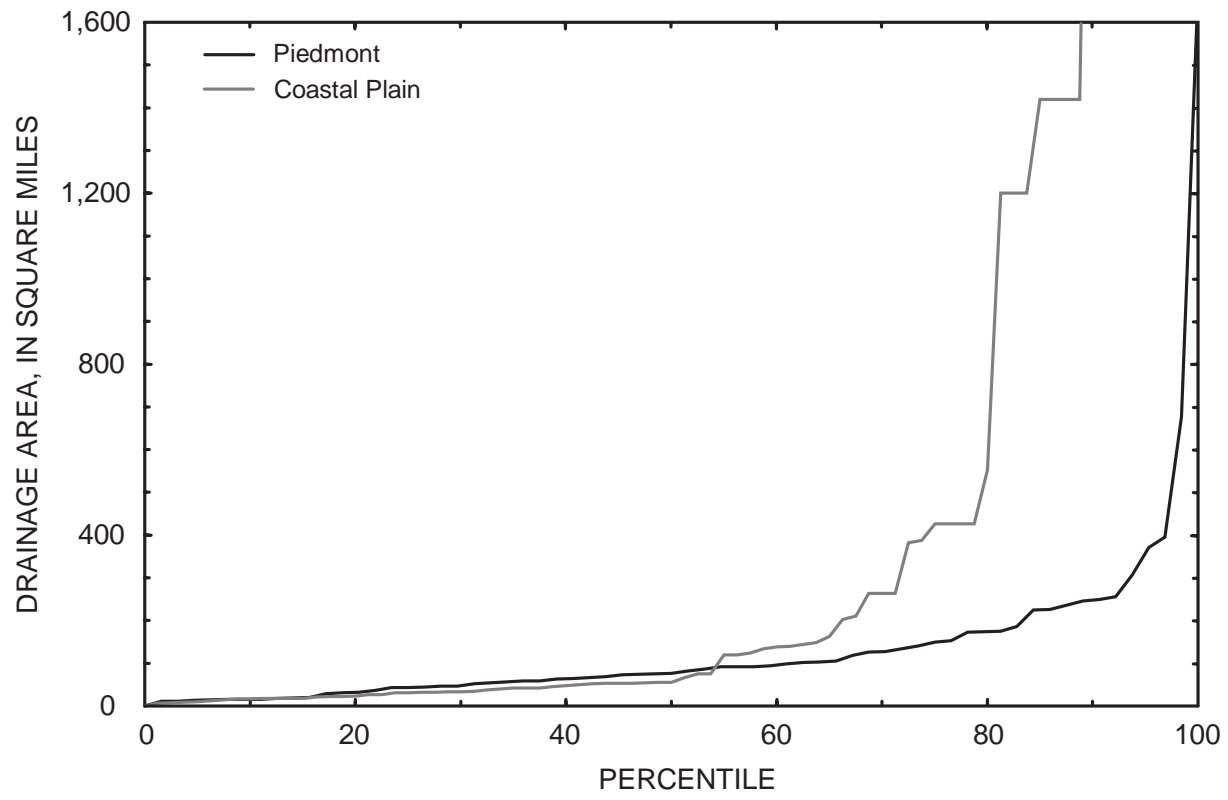

Figure 3. Distribution of drainage areas for bridge-scour study sites in the Coastal Plain and Piedmont of South Carolina. (Note: Vertical scale has been truncated for graph clarity at small drainage areas.) 
upstream approach flows do not transport bed sediments into the area of scour. Under these conditions, sediments do not refill the scoured area and a nonobscured record of the maximum scour is preserved at that location. This record can be readily measured during postflood investigations, and the measured scour represents the maximum clear-water scour that has occurred during the life of the bridge. (This assumes that the scoured area has not been disturbed by repair of previous scour; efforts should be made to validate this assumption through investigation of bridge-maintenance records.) For older bridges, this record of clear-water scour provides some indication of the maximum anticipated scour that may occur during the life of a bridge. Because of the relative ease of measuring clear-water scour, in contrast to live-bed scour, this study focused on the collection of clearwater scour data.

Many bridge-scour data-collection studies have focused on collecting data during floods in order to associate the measured scour with the hydraulic conditions that produced it. The laboratory-derived equations in HEC-18 (Richardson and Davis, 1995) use hydraulic variables, such as velocity and depth, to predict scour. Therefore, an obvious advantage of collecting concurrent scour- and hydraulic-field data is the ability to directly verify the laboratory-derived equations and (or) develop new equations from measured hydraulic properties. An important limitation of such studies is the dependency on the occurrence of floods. If floods of substantial magnitude do not occur during the study duration, no data are collected. The probability of collecting scour data during large-magnitude floods increases as the geographic area and duration of the study increases. However, with the geographic area limited to the boundaries of South Carolina and with a data-collection period of about 2 years, the probability of collecting a significant quantity of field data during large floods was considered low. In fact, no significant floods occurred in South Carolina during the primary data-collection phase (1996-97) of this study.

To overcome this limitation, the scope of this study focused on the collection of maximum historic scour depths at numerous bridge sites, rather than collecting scour depths associated with a particular flood. The maximum historic scour depth is defined as the maximum contraction or abutment-scour depth that has occurred at a given bridge since construction. Although these data do not allow the direct verification of the HEC-18 scour equations, they do provide ranges of maximum historic scour depths that should be anticipated for site-specific conditions. These ranges can be used to assess the reasonableness of the theoretical values obtained from HEC-18 and provide a basis for modifying the theoretical value, if necessary. For example, if the theoretical contraction scour on the clayey overbank at a Piedmont bridge is estimated to be $20 \mathrm{ft}$ for the 100-year flow, yet the range of observed maximum scour depths on the overbanks at bridges with similar site conditions is 0.0 to $4.5 \mathrm{ft}$, one could conclude that the theoretical scour is excessive. Using the field data, along with the comparison of sitespecific conditions, the theoretical scour depth could be adjusted to conform to observed data. In this case, the theoretical-contraction scour depth might be adjusted to $4.5 \mathrm{ft}$ to reflect the upper limit of the maximum observed scour depths.

When using observed scour data in such a manner, it must be assumed that (1) the collected field data reflect scour resulting from floods, such as those approaching the 100-year flow magnitude that have occurred since bridge construction and that (2) the scour depths are near equilibrium conditions for such flows. [The concept of equilibrium-scour conditions has been derived from laboratory investigations, and refers to the state where scour has reached an ultimate depth for a constant flow. To obtain clear-water scour equilibrium conditions, laboratory experiments are often conducted for several days (Dongol, 1993).] If the collected field data reflect scour that has resulted only from minor floods, then the data cannot be used to assess scour resulting from large floods, such as those near the 100-year flow magnitude. Likewise, if the observed scour depths are not near equilibrium conditions for large flows, then the collected field data will tend to underestimate ultimate scour depths for large floods. In reality, assumptions 1 and 2 are interdependent, in that a site cannot achieve equilibrium-scour conditions for large flows unless large flows have occurred at the site. The assumption will be made that, if a large flow has occurred at a given site, then the observed clear-water scour is at equilibrium or is at least representative of scour that could be expected for other bridges with similar characteristics. 


\section{Justification for the Assumption of Large Flood Flows}

Support for assumption 1 can be obtained in several ways. From simple statistics, it is understood that as a bridge increases in age, the probability that the bridge has experienced a large flood also increases. Therefore, if clear-water scour data are collected at older bridges, then it is likely that the scour resulted from a large flood. If it can be shown that scour data in this study were collected at older bridges and that such bridges have a high probability of having experienced large flows, then assumption 1 can be substantiated. For purposes of this study, a large flood will be defined as any flow that equals or exceeds 70 percent of the 100-year flow magnitude. In South Carolina, the rural regression equations for predicting flow magnitudes (Guimaraes and Bohman, 1992) show that the 25-year flow is equal to approximately 70 percent of the 100year flow magnitude. Therefore, a large flood, as defined in this study, is any flood that equals or exceeds the magnitude of the 25-year flow. Using this recurrence interval with a binomial distribution, a risk analysis can be made (Bedient and Huber, 1988) to determine the probability that the 25-year flow will occur at least once at a bridge of given age. The equation is defined as follows:

$$
\text { Risk }=1-(1-1 / T)^{n},
$$

where

$$
\begin{aligned}
& \text { Risk is the probability that the } T \text {-year event will occur } \\
& \text { at least once in } n \text { years; } \\
& T \text { is the recurrence interval, in years; and } \\
& n \text { is the period for assessing risk, in years. }
\end{aligned}
$$

For selected bridge ages, table 1 lists the risk for the occurrence of a 25-year flow. As can be seen, bridges that are 30 years or older have a fairly high probability of having experienced a flood exceeding the 25-year recurrence interval. that equals or exceeds the 25-year flow. For bridges that are 30 years or older, this simple risk analysis provides support for the validity of the assumption that the collected scour data resulted from large floods. A review of historic flood records for the 27 bridges that are less than 30 years of age shows that 11 of these sites are known to have experienced floods that have exceeded the 25-year flow, giving further support for assumption 1 .

Assumption 1 can be further substantiated from streamflow gaging station records. Referring to figure 4, about 70 percent of the bridges (101 out of 146) in this study are 40 years or older. A review of 277 USGS streamflow gaging station records (for stations that were operated for all or part of the 40-year period, 1956-96) shows that flows equaling or exceeding 70 percent of the 100 -year flow magnitude occurred at 50 gages in South Carolina. (Only 32 of the 277 streamflow gaging stations were operational for the full 40-year period from 1956-96.) A plot of the 50 gages on a map of South Carolina (fig. 5) shows a wide spatial distribution, indicating that much of South Carolina has experienced at least one large flood during the 40-year period of interest. When 40-year-old bridges, surveyed in this study, are superimposed on the same map (fig. 5), there is significant overlap between the gaging stations and bridge sites, again indicating that large floods probably occurred at many of the bridges 40 years or older. A review of historic flood records for the 45 bridges that are less than 40 years of age shows that 16 of these sites are known to have experienced floods that exceeded the 25-year flow, giving further support for assumption 1. [An additional gaging station (02110704) influenced by the 1999 flood along the Waccamaw River is included on figure 5. This gaging station did not experience a flow exceeding 70 percent of the 100 -year flow prior to 1999 ; however, the 1999 flood exceeded the 100-year flow and postflood data were collected at selected bridges crossing the Waccamaw River.]

Table 1. Percent risk for the occurrence of the 25-year recurrence-interval flow for selected bridge ages

\begin{tabular}{c|l|l|l|l|l|l|l|}
\hline Bridge age, in years & 10 & 20 & 30 & 40 & 50 & 60 & 70 \\
Risk, in percent & 33 & 56 & 71 & 80 & 87 & 91 & 94 \\
\hline
\end{tabular}

A percentile plot of bridge age (fig. 4), shows that about 80 percent of the bridges in this study are 30 years or older and, therefore, have a 71-percent probability of having experienced a flow magnitude
Finally, assumption 1 can be substantiated by reviewing four historic floods that have occurred since 1990. South Carolina is in a hurricane-susceptible region and frequently experiences heavy rainfalls associated 


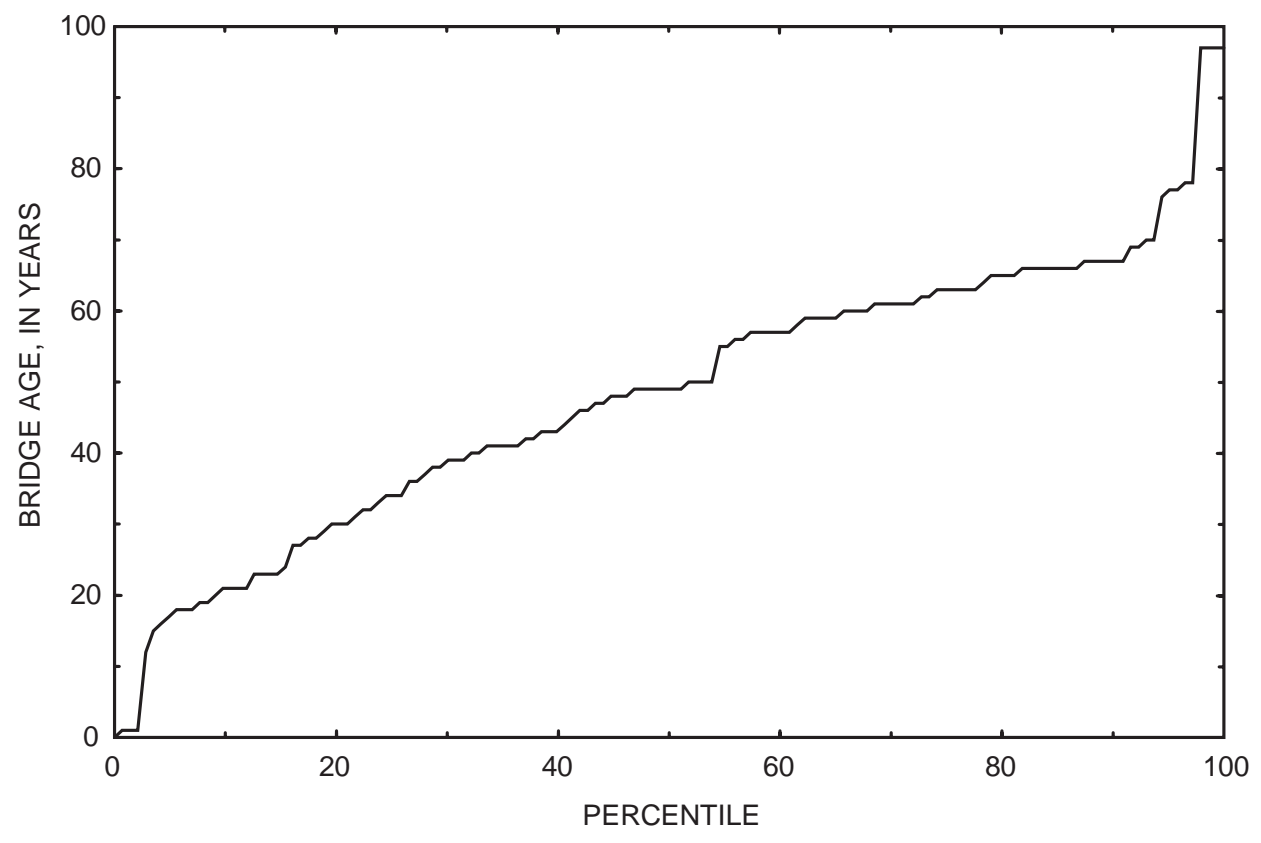

Figure 4. Distribution of bridge age for bridge-scour study sites in the Coastal Plain and Piedmont of South Carolina.

with tropical storms. In addition, thunderstorms occur frequently, creating heavy rainfall for more localized areas. Since 1990, South Carolina has experienced four storms that have caused extensive flooding in various parts of the State. In October 1990, Tropical Storms Klaus and Marcos stalled over South Carolina dropping 8-10 inches (in.) of rainfall in the Coastal Plain over a 24-hour period (R.N. Cherry, U.S. Geological Survey, written commun., January 1991). Flow magnitudes were high, exceeding the 100-year recurrence interval at various locations and causing the failure of 80 bridges (Hurley, 1996). Twenty-five bridges in this study exist in this region (fig. 6). Although documentation of flows from these storms is not available at these bridge sites, it is probable that they experienced flows equaling or exceeding the 25-year flow magnitude.

In October 1992, approximately 9 in. of rain fell in 24 hours over Allendale, Bamberg, Colleton, and Hampton Counties. This storm produced extensive flooding with flow magnitudes exceeding the 100-year flow (T.H. Lanier, U.S. Geological Survey, written commun., December 1993). Eighteen bridges in the current study exist within the region of this storm (fig. 6) and flow magnitudes for 8 of these sites have been estimated from high-water marks, indirect computations, and gaging station data (fig. 5). Recurrence intervals for these sites ranged from 70 years to greater than 100 years with six sites exceeding the 100-year flow magnitude. Although documentation of flow is not available at the remaining 10 bridges, it is probable that they experienced flows that equaled or exceeded the 25-year flow magnitude.

In 1995, extensive flooding occurred in the Piedmont when Tropical Storm Jerry produced 8-20 in. of rainfall over a 4-day period. Flows with recurrence intervals ranging from 10 years to greater than 100 years were recorded in this region and flow magnitudes along the Enoree River ranged from 1.4 to 5.2 times the 100year flow (A.W. Caldwell, U.S. Geological Survey, written commun., January 1996). Twenty-seven bridges in the current study exist within the region affected by this storm (fig. 6), and flow magnitudes for 12 of these sites have been estimated from high-water marks, indirect computations, and gaging station data (fig. 5). Eight of the sites with estimated flows have magnitudes that exceed the 100-year flow magnitude. Although 15 of the 27 sites affected by the 1995 flood do not have flow documentation, it is probable that 8 of these sites have experienced flows that equaled or exceeded the 25-year flow magnitude. Therefore, about 20 sites in this study experienced flows equaling or exceeding the 25 -year flow during the 1995 flood. 


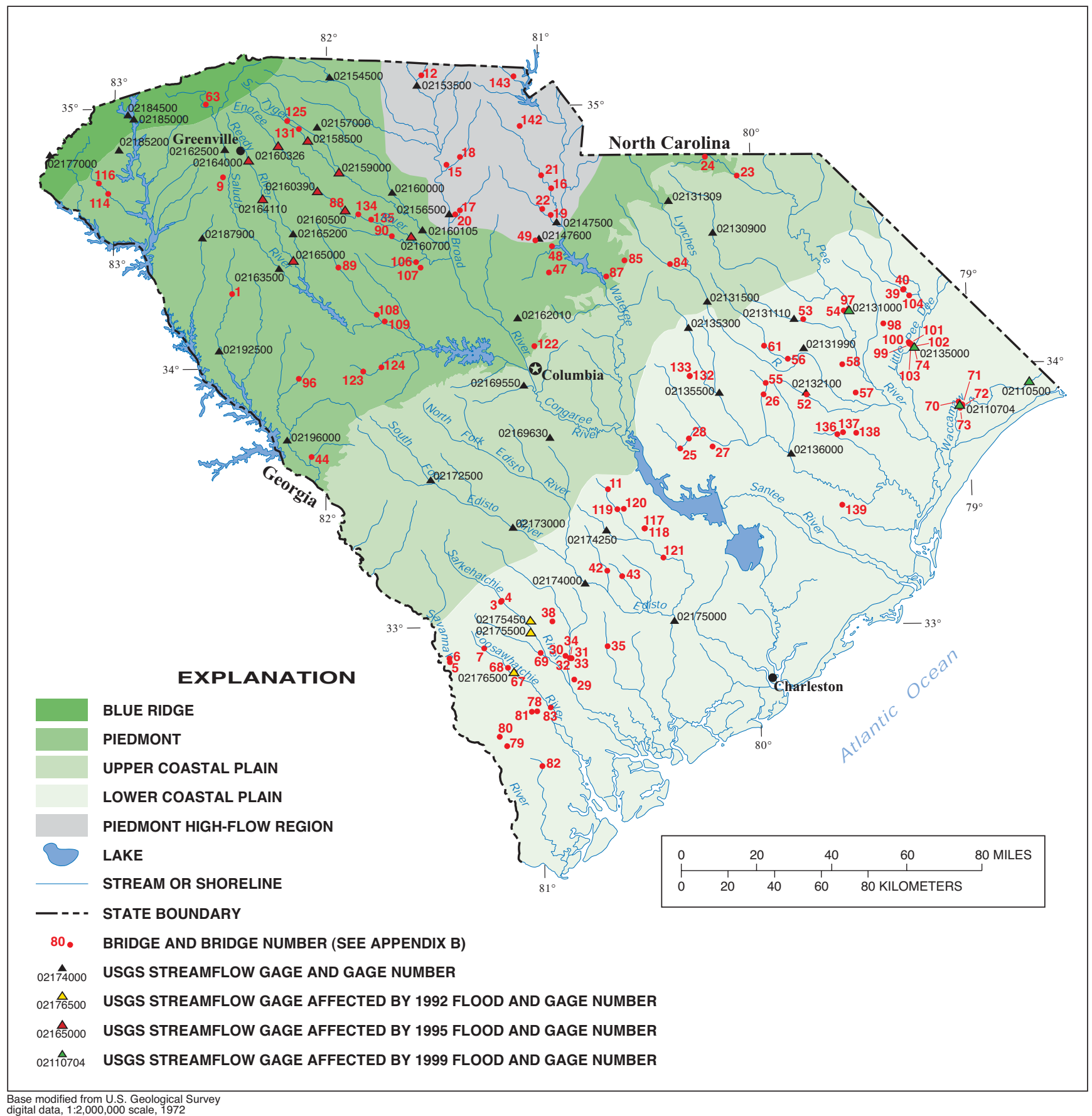

Figure 5. Location of study bridges 40 years or older and streamflow gaging stations experiencing at least one flow equaling or exceeding 70 percent of the 100-year flow during 1956-96. (Refer to appendix B at back of report to identify bridge with corresponding number.)

In September 1999, Hurricane Floyd produced extensive flooding along the Waccamaw River Basin in Horry County, South Carolina, where flow magnitudes exceeded the 100-year flow. Seven sites with estimated flows along the Waccamaw River (fig. 6) were included in this study. In addition, eight bridges along the Pee Dee and Little Pee Dee Rivers (fig. 6) also were influenced by this storm and were included in this study. Although flows on the Little Pee Dee and Pee Dee Rivers did not exceed the 25-year magnitude during the 1999 flood, long-term gaging station data at these bridges indicate maximum historic flows near the 25-year flow magnitude have occurred on both rivers since the construction of the bridges. 


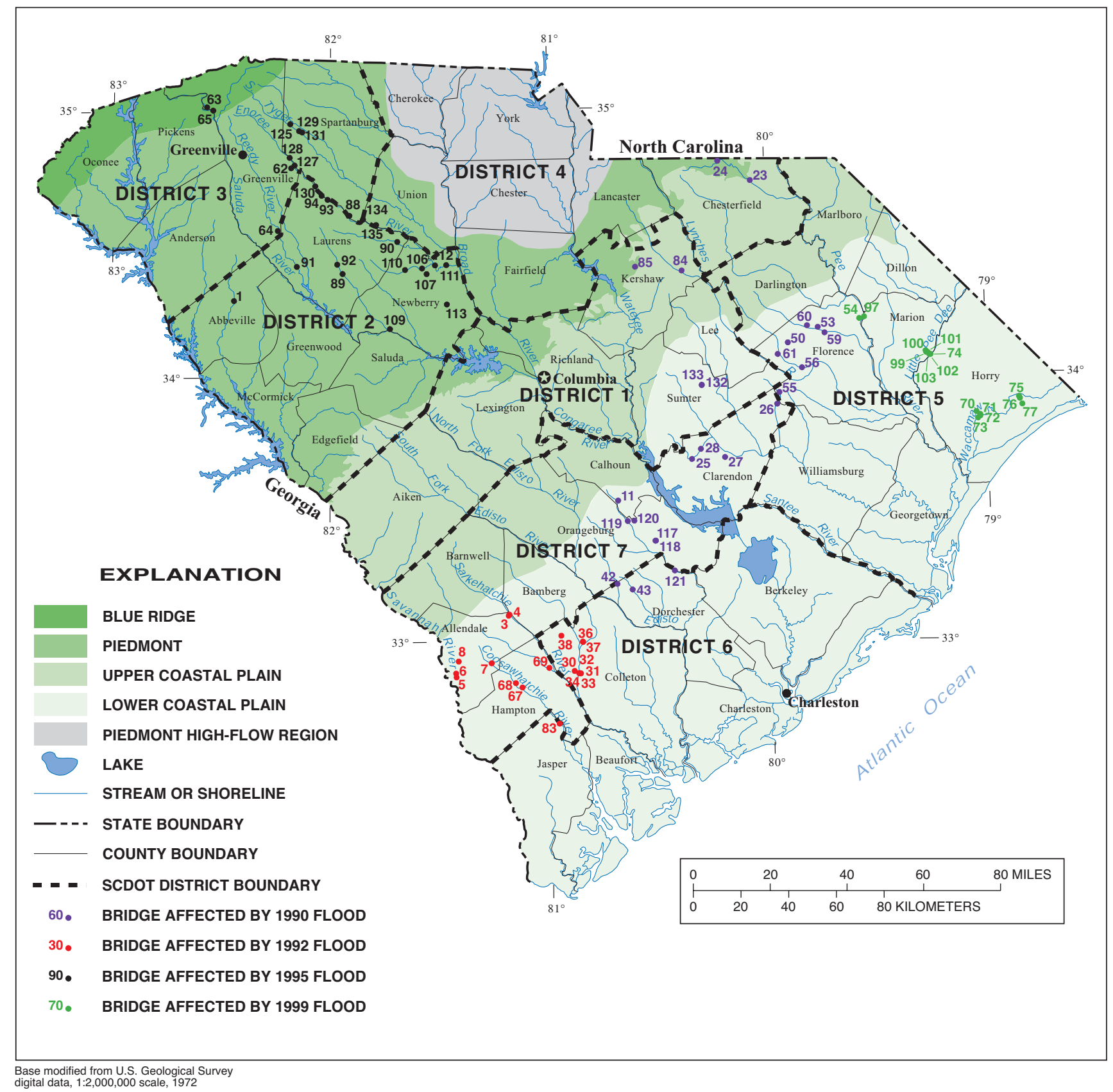

Figure 6. Location of bridge-scour study sites affected by selected historic floods in South Carolina. (Refer to appendix B at the back of report to identify bridge with corresponding number.)

The four reviewed floods occurred over a 9-year period (1990-99) and affected approximately 78 bridges in the current study. It is probable that these bridges experienced flows equaling or exceeding the 25-year flow magnitude. Thirty-five of the 78 bridges have some estimate of peak flood flows and 21 of these had flows that equaled or exceeded the 100-year flow magnitude. It also should be kept in mind that other floods occurred prior to 1990, but were not reviewed for this study because documentation was not readily available. An investigation of floods prior to 1990 would certainly increase the number of bridges known to have actually experienced large flows. The evidence from the four recent floods provides support of the assumption that the scour data collected in this study represent scour that has resulted from large flows. 
Although not all bridges in this study can be guaranteed to have experienced at least one large flood, from a review of statistical inference, gaging station records, and historic flood data, strong evidence has been provided to show that 78 of the 146 bridges have likely been subjected to floods equaling or exceeding the magnitude of the 25-year flow. This supports the assumption that the scour data collected in this study reflect scour resulting from large floods. Therefore, the data will likely provide some estimate of anticipated ranges of scour for high-flow conditions at bridges in South Carolina.

\section{Justification for the Assumption of Equilibrium-Scour Conditions}

The assumption that the observed scour depths collected in this study reflect equilibrium depths is more difficult to support. As mentioned previously, the inference that a large number of the bridges in this investigation have experienced large flows, gives support for the assumption that collected scour data are at or near equilibrium conditions resulting from such flows.

Local scour develops when bed-shear stresses around a pier or abutment exceed the critical shear stress for a given bed material. As the scour hole deepens, the bed shear stresses are reduced. Under steadyflow conditions, the progression of clear-water scour will reach a point where shear stresses are no longer sufficient to remove significant amounts of bed material. This condition is typically defined as the equilibrium-scour depth and represents the maximum scour that will occur for a given constant flow (Richardson and Davis, 1995). Because peak flood flows of prolonged duration are rarely observed in the field, it is questionable if the concept of equilibrium-scour depth for a constant peak flood flow is applicable to field conditions.

Raudkivi and Sutherland (1981) investigated the effects of unsteady flow on clear-water pier scour and compared the results with steady-flow equilibrium scour. Their research shows that the passage of a single flood hydrograph produces a scour depth less than the equilibrium-scour depth associated with the peak flow, under steady-state conditions. The duration of the hydrograph also was found to affect the scour depth, with unsteady-flow scour depths approaching steady- flow equilibrium depths as the hydrograph duration increased. In addition, the research showed that successive flood waves produced a progression of scour that eventually reached an equilibrium state after eight flood waves. However, the equilibrium-scour depth caused by the series of unsteady-flow events was always less than the steady state equilibrium-scour depth. Although this research was conducted for clearwater pier scour, it is reasonable to assume that the progression for clear-water contraction and abutment scour is similar. Based on this research, it is questionable if the concept of equilibrium-scour depth for a constant flood flow is applicable to field conditions.

The scour data collected in this study may not be at equilibrium-scour conditions as defined in laboratory studies. It is important to keep in mind that the data include observations at a large number of older bridges and at a large number of bridges that have likely experienced large floods. Regardless of the mechanism that produced the scour (sustained flows or a series of floods) the observations should give some indication of anticipated scour depths during the life of a bridge. As such, the data can be used in a limited manner to assess theoretical scour and to understand potential scour at similar sites.

\section{Basin Equilibrium Scour}

Although the concept of steady-flow equilibrium scour may not be applicable to field conditions, it is reasonable to assume that scour depths will approach some type of equilibrium condition for a given bridge and drainage-basin system. Some support for the concept of a basin equilibrium-scour depth can be developed by utilizing the principles of fluvial geomorphology. Numerous factors comprise and influence a drainage-basin system. Some of the major components include topography, geology, land cover, and hydrology (Simons and Associates, 1982). Given sufficient time, these components will develop a stable drainage-basin system that is considered to be in a state of equilibrium.

When modifications, such as land-use changes, are superimposed upon a stable basin, the system becomes unstable and adjustments within the system will occur to reestablish equilibrium conditions. In general, the stream networks of South Carolina can be considered relatively stable systems. If the principles of fluvial geomorphology are assumed applicable to 
bridges, a bridge can be viewed as a modification to a stable system that will force adjustments within that system. Flood flows that previously were in equilibrium with the floodplain geometry have now been forced to contract and pass through a bridge. This new flow path will force system adjustments, one of which will be bridge scour. With time, a bridge will experience the general flood patterns of the drainage basin, bridge scour will occur, and these scour depths will approach equilibrium conditions for the given drainage-basin system. If this model is correct, then sites with similar bridge geometry and basin characteristics will show similar trends in basin equilibrium-scour depths. Therefore, basins with common regional characteristics will likely show regional trends in bridgescour depths.

The principles of fluvial geomorphology offer some defense for the concept of a basin equilibriumscour depth, but leave some question about the time required to attain that state. Although a definitive answer to this question may not be available, some practical insights may be drawn. Because large flows are the driving force that will push a site towards basin equilibrium-scour conditions, sites that have experienced large flows are more likely to be at or near this condition. Likewise, by statistical inference, older bridges are more likely to have experienced several large flows and, therefore, are more likely to be at or near equilibrium conditions. As discussed previously, the sites for this study are fairly old (119 of 146 bridges were 30 years or older in 1996) and there is strong evidence to suggest that many of the sites have experienced large flows. Therefore, it is likely that much of the collected scour data for this study are at or near basin equilibrium-scour conditions.

\section{SITE SELECTION}

Five sources were used to find candidate sites for measuring clear-water contraction and abutment scour. These included (1) an SCDOT list of bridges with observed scour problems, (2) sites previously studied by the USGS in the level 2 bridge-scour study, (3) Piedmont sites influenced by the August 1995 flood, (4) Piedmont bridges with wide, flat floodplains as identified on topographic maps, and (5) Coastal Plain sites influenced by the September 1999 flood.

\section{SCDOT List of Bridges with Observed Scour}

The SCDOT makes routine inspections of all bridges within its jurisdiction. Part of the inspection includes observations of scour-related problems. To develop a list of potential study sites, the seven SCDOT Districts (fig. 6) were queried by letter regarding bridges with known scour problems. Scour problems were limited to three categories: (1) contraction scour at swampy sites, (2) pier scour, and (3) abutment scour. Scour at swampy sites was requested because swamps commonly have clear-water contraction and abutment-scour holes. Swamps were a primary focus of this study and such sites would provide good sources of data. Scour at piers was requested because such scour would give some indication that the site had experienced large flows providing potential for contraction or abutment scour. Sites with abutment scour were requested because of their relevance to this study. Additionally, abutment scour would indicate a potential site for clear-water contraction scour.

The list provided by the SCDOT contained 149 bridges for consideration. Seven of the sites were discarded because they were culverts or tidally influenced; 19 bridges were in category one, 104 in category two, and 19 in category three. Although site visits were made to 123 bridges to determine if they would be candidates for collecting field observations of scour, only 9 of these sites were selected as potential candidates for data collection. The primary reason for discarding most of the bridges was that the predominant type of scour occurring at these sites was caused by bank failure. Most of these bridges were short in length and crossed streams having a defined channel with narrow overbank areas under the bridge. The abutments were commonly vertical timber walls with the abutment toes near the channel banks. Contractionscour processes were widening the channel at the bridge by bank failure and bank failure presented potential problems for the timber wall abutments or nearby pile bents. Because the area of scour predominately encompassed the live-bed channel, these sites were considered outside the scope of investigating clear-water scour. In addition, scour at these sites was not primarily bed degradation, but channel widening, which again placed the sites outside the scope of this investigation. Figure 7 shows the distribution of bridge lengths for the 114 discarded sites. Approximately 83 percent of these bridges were less than $100 \mathrm{ft}$ long and 94 percent were less than $200 \mathrm{ft}$ long. 


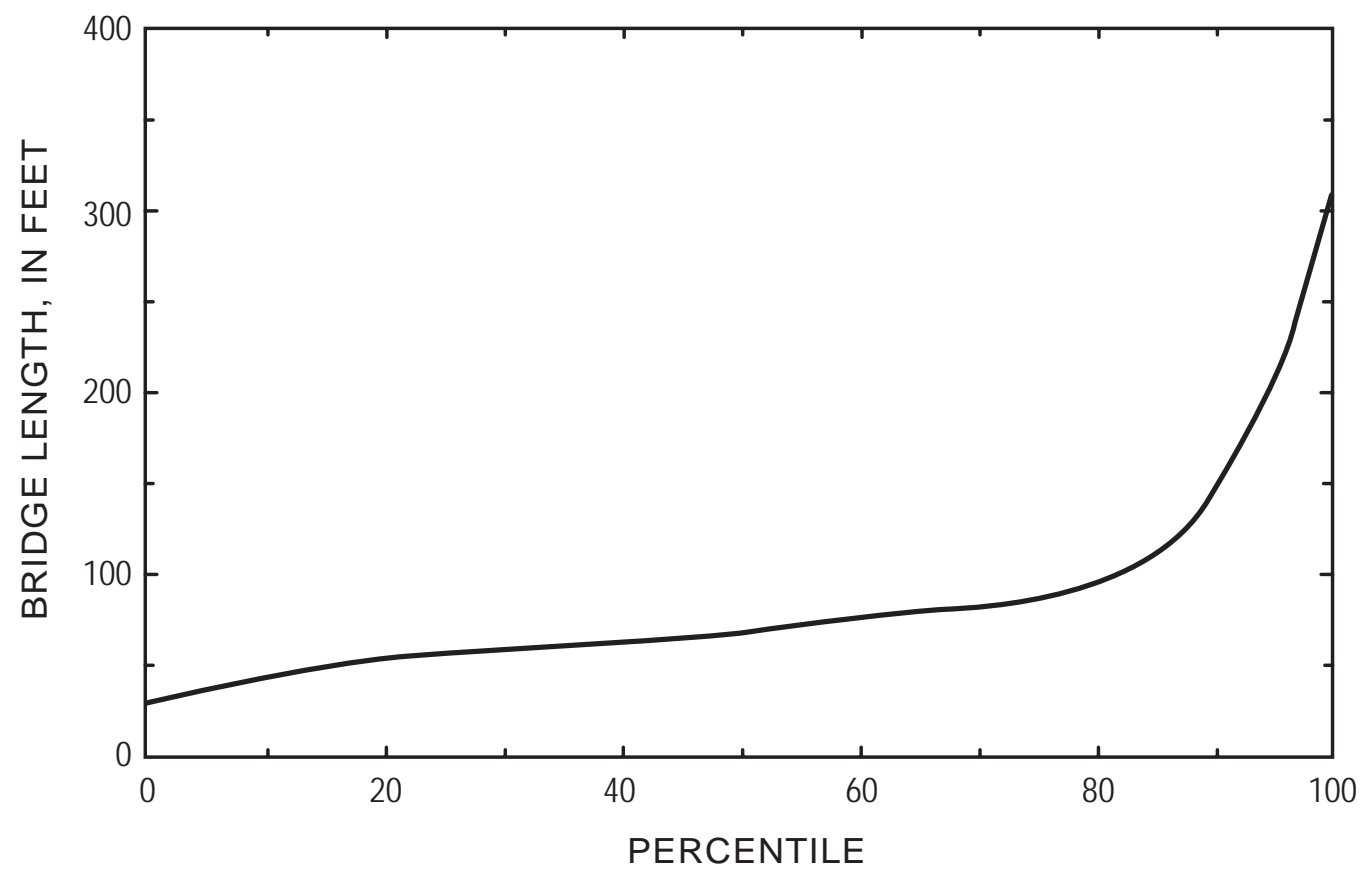

Figure 7. Distribution of bridge lengths for sites discarded from the South Carolina Department of Transportation list of bridges with observed scour problems.

The nine sites selected for possible field measurements had a range of bridge lengths from 75 to $420 \mathrm{ft}$ with abutment scour being the predominant observed scour. Five of these sites were selected for this study, one of which had been studied in the level 2 bridge-scour study.

Although the list of bridges received from the SCDOT did not result in many sites for this study, the list did provide insights about the scour problems that occur at small bridges in South Carolina. These smaller bridges create considerable contraction of flow as evidenced by channel widening at the sites. Additionally, these bridges often experience abutment failure during floods. The nature of the abutment failure is typically not degradation but washout of the road fill at the abutments, leaving the bridge structure intact, but the road approaches destroyed. This is the most common type of bridge failure in South Carolina. For example, floods caused by rainfall from Tropical Storms Klaus and Marco in October 1990, caused 80 bridges to fail in South Carolina, 79 of them by the washout of the road fill at the abutment (Hurley, 1996).

\section{Selection of Previously Studied Level 2 Bridge-Scour Sites}

A primary objective of this investigation was to analyze field measurements of scour with selected explanatory variables to determine if relations exist that help explain scour at bridges in South Carolina. Hydraulic variables were considered an important part of this analysis. Because concurrent flow data were not collected with the scour measurements, hydraulic variables at each site were estimated using the WSPRO model (Shearman, 1990). Developing WSPRO models is a time consuming and expensive process. To minimize these costs, level 2 bridge-scour sites, with previously developed WSPRO models, were used for this study.

In the level 2 bridge-scour study, the USGS analyzed 293 bridges in South Carolina with 133 located in the lower Coastal Plain, 37 in the upper Coastal Plain, and 123 in the Piedmont. An initial subset of bridge sites was taken from these studies using selection criteria that indicated high potential for clear-water contraction and abutment scour. Selection criteria included an assessment of hydraulic conditions and theoretical clear-water scour depths for the 
100-year flow as determined in the level 2 studies. Large values of contraction ratio, bridge-flow velocity, bridge backwater, and theoretical clear-water scour were considered good indicators for high scour potential. An attempt was made to select sites that would provide some variation in drainage-area size, bridge length, and spatial distribution. From this subset of bridge sites, 105 sites were included in the present study with 60 located in the lower Coastal Plain, 4 in the upper Coastal Plain, and 41 in the Piedmont.

\section{Selection of Piedmont Sites Influenced by the August 1995 Flood}

To select additional Piedmont sites, a reconnaissance trip was made to bridges that had experienced the August 25-29, 1995, flood caused by rainfall from Tropical Storm Jerry. Flood flows for this event were documented by the USGS using high-water marks, indirect computations, and gage data. Records show that flows during this event often exceeded the 100year flow magnitude. Bridges that experienced this flood should provide good examples of anticipated scour depths during high flows. Forty-eight sites along the Enoree, Reedy, and South Tyger Rivers were visited and most sites showed only minor signs of abutment and contraction scour. Fourteen representative sites were included in the present study, one of which was also on the SCDOT list of problem sites.

Three of the surveyed flood sites had large abutment-scour holes that ranged from 5.2 to $13.7 \mathrm{ft}$ deep. These depths approached the scour depths seen more commonly in the sandy Coastal Plain swamps, and significantly exceeded depths typically observed in the clayey soils of the Piedmont. The soils at these sites appeared to be more susceptible to scour than the cohesive soils typically associated with the Piedmont and played some role in the development of the larger scour depths. But an additional factor that could be associated with these large abutment-scour depths was the floodplain geometry consisting of wide, flat floodplains. Because streams of the Piedmont tend to have narrow river valleys, the wide, flat floodplains are prominent features on the USGS 7.5-minute series topographic maps, making the topographic map a useful tool for identifying such sites having high scour potential.

\section{Selection of Piedmont Bridges with Wide, Flat Floodplains}

Based on the observation that high scour potential in the Piedmont could be associated with wide, flat floodplains, all (220) topographic maps covering the Piedmont Province were reviewed to identify such sites. The review showed that most bridge crossings in the Piedmont are at the more narrow river valleys. However, 58 sites were noted to have wide, flat floodplains and reconnaissance trips were made to these sites to determine if they might be good candidates for measuring clear-water scour. Of these 58 bridge sites, 11 had short bridges with little or no overbanks; 6 had only minor scour; 1 had scour-remedial action present (riprap on overbanks); 8 had bridges that were being replaced and, therefore, scour could not be assessed; and 32 had moderate to large scour depths ranging from approximately 3 to $18 \mathrm{ft}$. Using the pool of 32 bridges with observed scour, 18 sites were selected for inclusion in this study, 11 of which had been previously selected from the level 2 studies, the 1995 flood sites, or the SCDOT list of problem bridges. The remaining 7 were surveyed for clear-water contraction and abutment scour.

\section{Selection of Coastal Plain Sites Influenced by the September 1999 Flood}

In September 1999, rainfall from Hurricane Floyd produced extensive flooding along the Waccamaw River Basin in Horry County. Flow magnitudes on the Waccamaw River exceeded the 100-year flow. This event also produced flooding along the Pee Dee and Little Pee Dee Rivers. The Waccamaw, Pee Dee, and Little Pee Dee Rivers have wide floodplains ranging from approximately 8,000 to $16,000 \mathrm{ft}$, and bridge crossings often create large contractions of flow providing a high potential for bridge scour. Because sites along these rivers had experienced a significant flood, a survey was conducted to select a number of sites to be included in this study. Eight bridges with estimated flows were selected along the Waccamaw River, as well as eight along the Pee Dee, and Little Pee Dee Rivers. (One of the Waccamaw River bridges was later dropped because the site had been disturbed by construction equipment.) Although flows on the Little Pee Dee and Pee Dee Rivers did not exceed the 25-year magnitude during the 1999 flood, long-term gages at the selected bridges indicated that maximum historic flows near the 25-year flow had occurred since construction of the bridges. 


\section{TECHNIQUES FOR THE COLLECTION AND INTERPRETATION OF FIELD DATA}

Basic field data collected at each clear-water scour site included (1) measurements of scour depths, (2) collection of bed-material samples from the unscoured and scoured areas, (3) estimates of infill depths, and (4) description of the site by photographs, sketches, and written records. Because the magnitude of the scour-hole depths varies between the Coastal Plain and Piedmont, the approach to collecting the field data in these regions was slightly different.

\section{Data Collection in the Coastal Plain}

In the Coastal Plain swamps, standing water typically covers the floodplain throughout the year, making scour holes difficult to locate visually. To determine the location and extent of scour at such sites, it is necessary to rely upon sonar equipment deployed by a small manned craft. A two-man inflatable boat and paper-chart fathometer (figs. 8 and 9, respectively) were used to investigate the lateral and longitudinal limits of scour. After locating the scour-hole limits, more detailed fathometer traces were obtained, including longitudinal and cross-sectional bed profiles. Based on the fathometer traces, appropriate cross-section locations were determined for the collection of detailed topographic-survey data. These data were collected with a total-station survey instrument and were used to develop contour plots of the scour holes (fig. 10). Scour holes in the Coastal Plain were commonly large enough to encompass piers or pile bents, but the effect of pier scour could not be isolated. Therefore, measured scour, in general, represents total scour and not just the component of abutment scour.

In the Coastal Plain, it is possible to have shallow low-flow channels that pass through a large scour hole. In this study, such conditions occurred most commonly at bridges under $240 \mathrm{ft}$ in length where a large, single

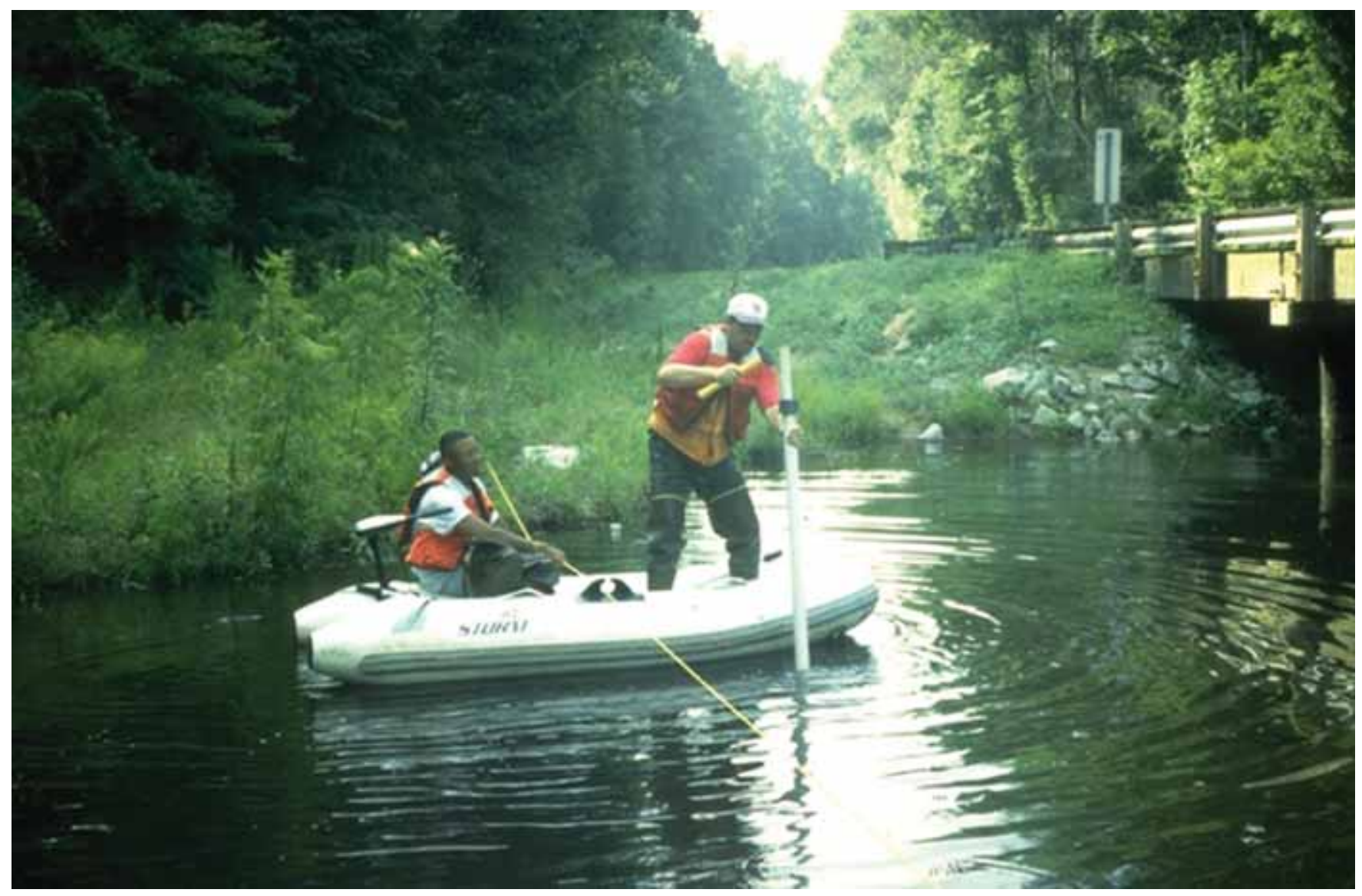

Figure 8. Inflatable boat used to collect field data at swampy sites in the Coastal Plain of South Carolina. (Photograph by the South Carolina District, U.S. Geological Survey, 1996.) 


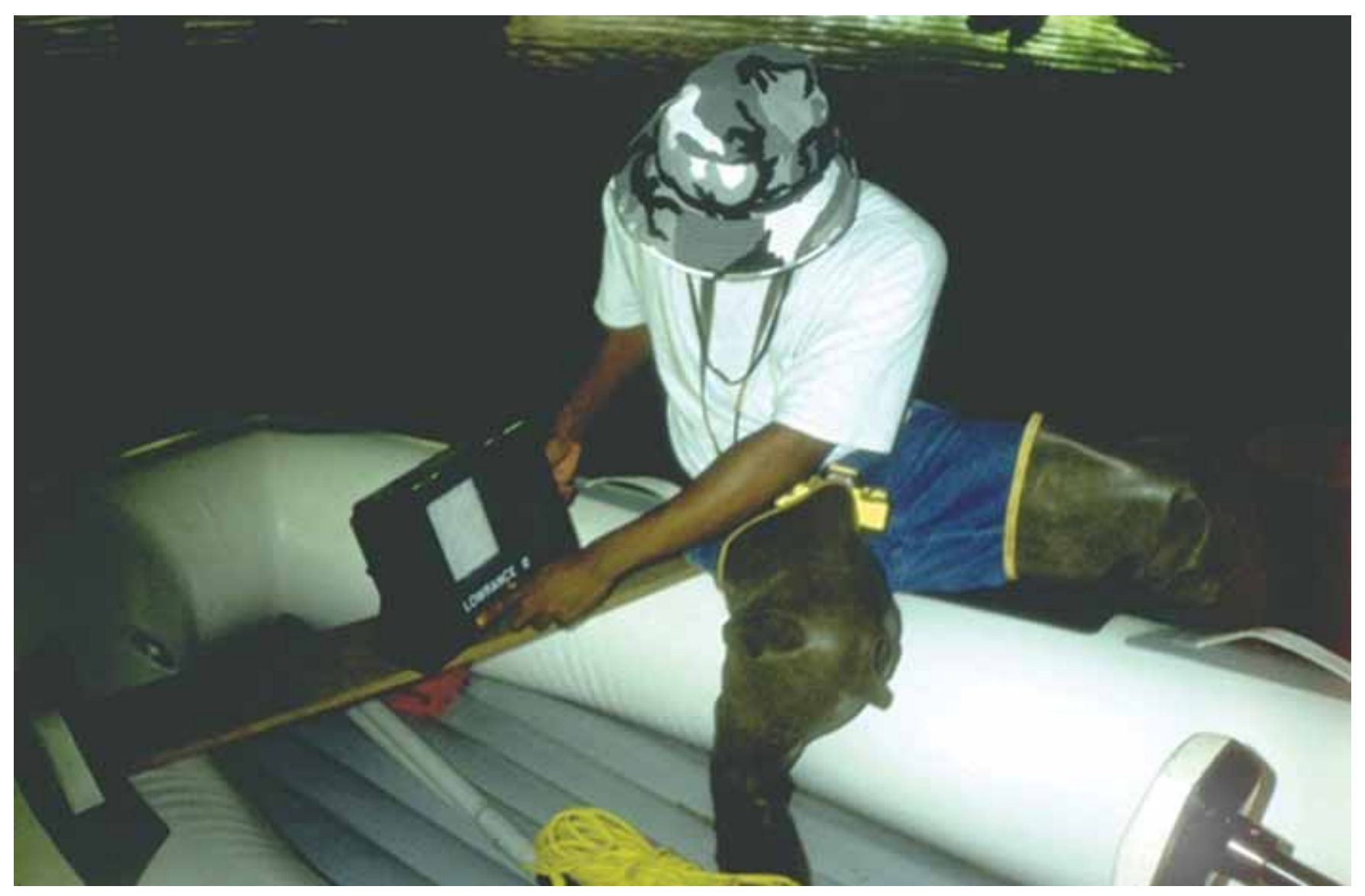

Figure 9. Paper-chart fathometer mounted on inflatable boat used to investigate limits of scour holes in the Coastal Plain of South Carolina. (Photograph by the South Carolina District, U.S. Geological Survey, 1996.)

scour hole developed at the bridge rather than separate left and right abutment-scour holes. Out of the 109 observations of abutment scour in the Coastal Plain, 42 observations had this shallow channel and all but one were bridges $240 \mathrm{ft}$ or less in length. The depth of these shallow channels ranged from 1.0 to $4.6 \mathrm{ft}$ with a median depth of $2.5 \mathrm{ft}$. At such sites, it was possible to use the shallow channel as a reference surface. However, the average, undisturbed floodplain elevation in the area of the observed scour was considered a more stable reference, as well as a reference that could be more consistently assessed. Therefore, scour depths at these sites, as well as all other Coastal Plain sites, were referenced to the average, undisturbed floodplain elevation in the area of the scour hole. In general, the upstream and downstream floodplain elevations, outside the area affected by scour and excluding the influence of any shallow channels, were used to determine this reference surface. In addition, available cross-section and SCDOT road plans data were reviewed to confirm the estimated reference surface. In certain cases, the survey of the upstream and downstream reference surface was not taken at a sufficient distance from the scour hole and the measured surface did not represent the undisturbed floodplain. In these cases, surveyed cross sections and SCDOT plans were relied upon to determine the average, undisturbed floodplain elevation. Although abutment-scour depths referenced to the shallow channels were not used in this report, the data were included for information in the bridge-scour database.

After collecting the survey data, bed-material samples were obtained by driving a 2-in.-diameter polyvinyl chloride (PVC) pipe (figs. 8, 11, and 12) into the sediment, then removing the sediment from the tube. The drive-tube sampler allowed the collection of submerged bed material that was useful for estimating sediment infill. In general, bed samples were collected from the low point of the scour hole and from the 


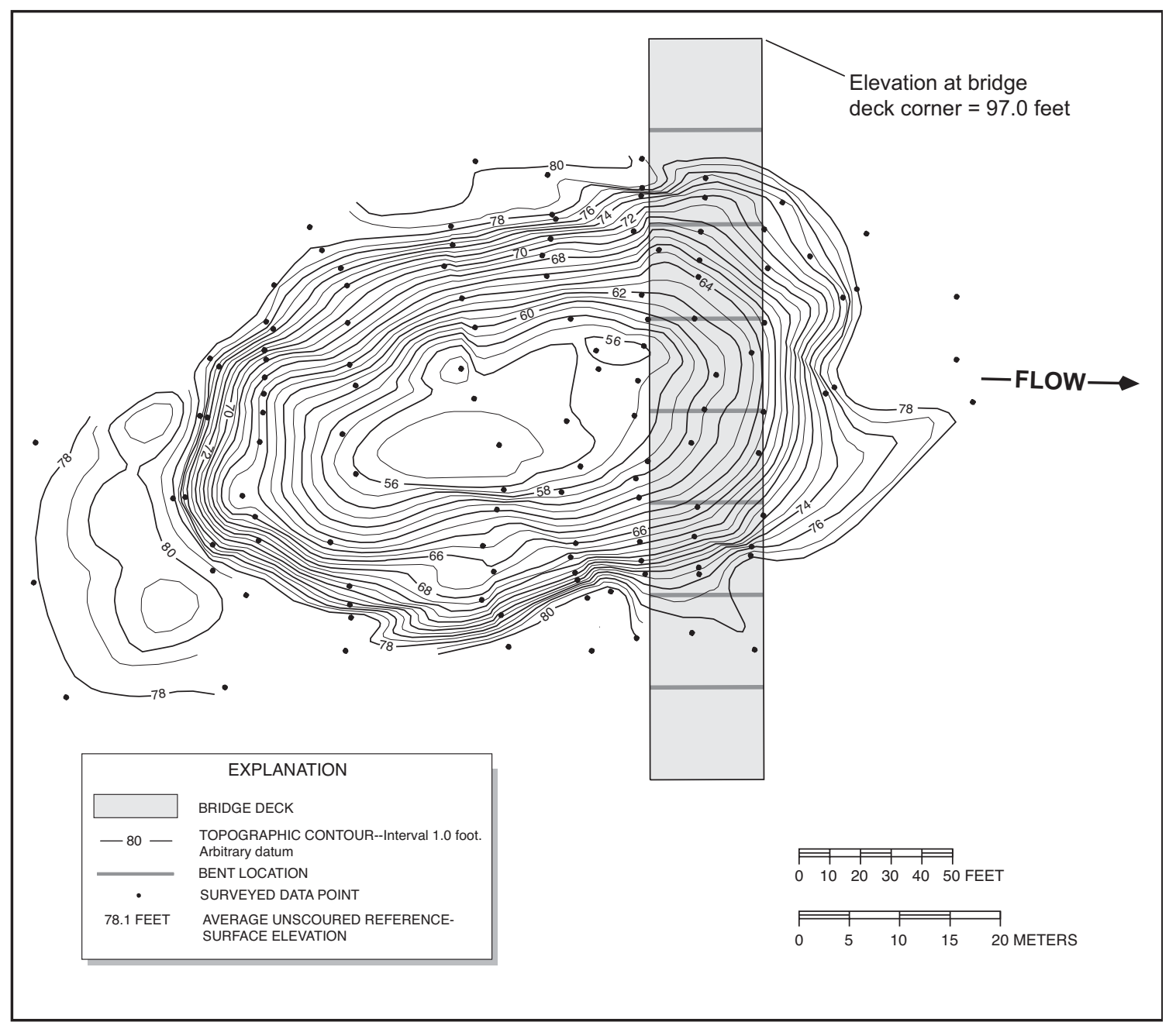

Figure 10. Example of scour-hole contour plot developed from topographic-survey data at Structure 211009511400 on Interstate 95, crossing the Pee Dee River floodplain in Florence County, South Carolina, August 19, 1996.

upstream natural bed. Two cores were collected from each location. One core was preserved for future reference and a grain-size distribution analysis was made on the other sample. The material at the bottom of the scour hole was often different from that of the upstream bed, because the scour had cut through the surface alluvium and into a geologic formation.

Because sediment transport is limited under clear-water scour conditions, infill in clear-water scour holes is typically shallow or even nonexistent. In this study, for the 109 observations of abutment scour in the Coastal Plain, infill ranged from 0.0 to $4.6 \mathrm{ft}$ with a mean of $0.7 \mathrm{ft}$ and median of $0.3 \mathrm{ft}$. Two types of infill were observed for Coastal Plain sites and are defined in this study as pluff infill and sediment infill. Pluff infill is a very soft layer of material that rests on the surface of the scour hole and is comprised of organics and fine sediments. This layer can be easily penetrated and measured by probing with a range pole. Sediment infill is a layer of sandy material below the pluff that is somewhat harder to penetrate. The depth of sediment infill was determined from cores obtained from the low point of the scour hole. A distinct layer commonly observed in these cores clearly distinguished the sediment infill from the unscoured material and was used to estimate the sediment-infill depth. The combination of pluff and sediment infill gives the total infill, which was added to the measured scour-hole depth to determine the maximum scour depth. Pictures, sketches, and general descriptions of sites were made as needed. 


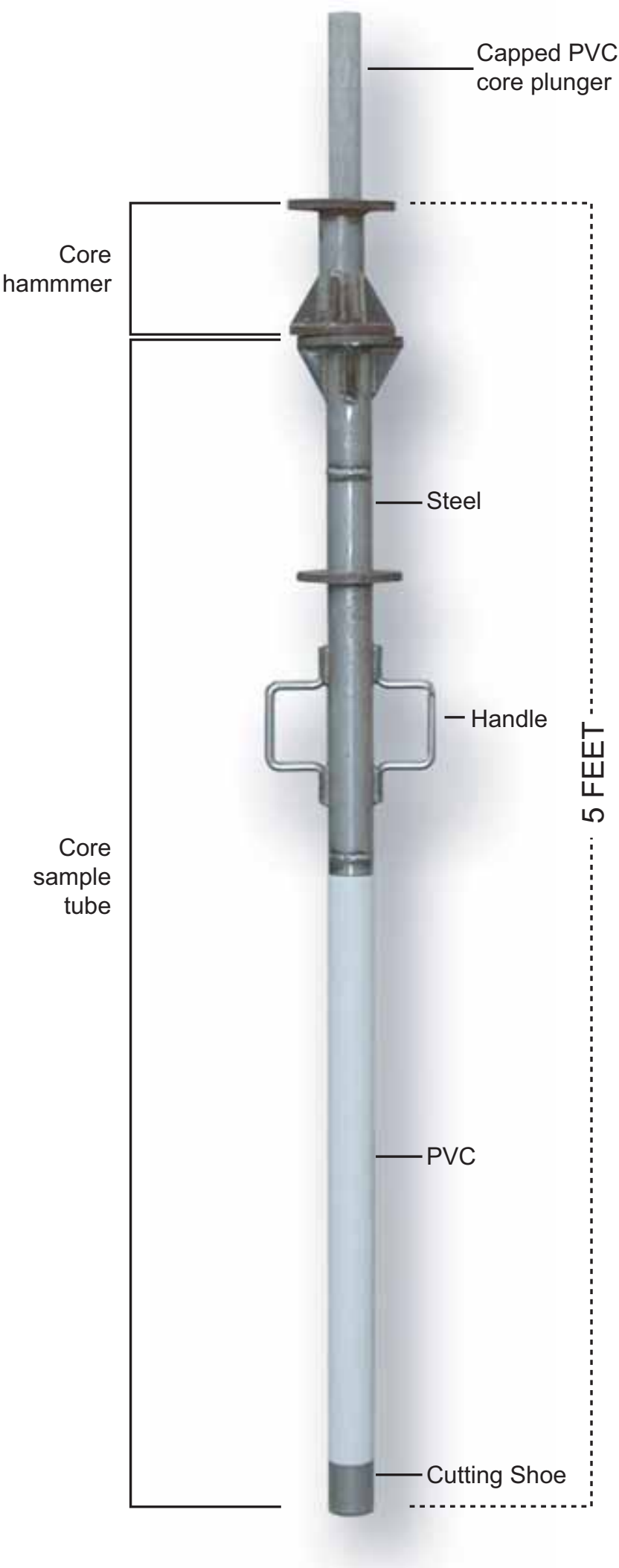

Figure 11. Drive-tube coring device used to obtain sediment samples from the bottom of submerged scour holes. (Photograph by the South Carolina District, U.S. Geological Survey, 2001.)

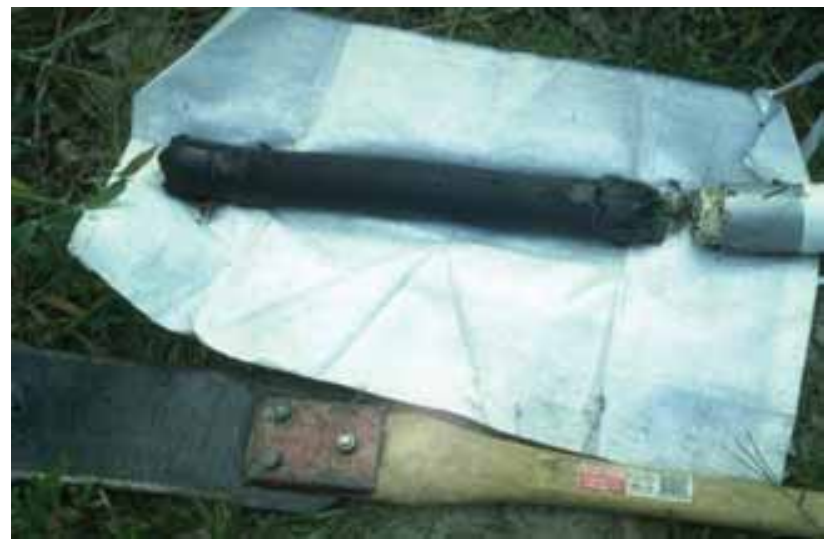

Figure 12. Example of sediment core collected from the bottom of a submerged scour hole using the drive-tube coring device. (Photograph by the South Carolina District, U.S. Geological Survey, 1996.)

\section{Data Collection in the Piedmont}

In contrast to the Coastal Plain, the clear-water scour holes of the Piedmont are located on the overbank area and tend to have shallower scour depths (fig. 13). These scour holes are typically dry and easily observed visually. Because the scour holes are relatively small, less detailed survey data were collected at these sites. Data included elevation measurements of the upstream- and downstream-unscoured surface and the low point of the scour hole. The average unscoured surface was used as a reference to determine the scour depth. This reference surface typically represented the average, undisturbed floodplain elevation in the vicinity of the scour hole. Available cross-section and SCDOT road plans data also were reviewed to confirm the estimated reference surface. In the case of abutment scour, the measured scour depth represented total scour, excluding the effect of pier scour. At some of the deeper abutment-scour holes, however, the measured abutment-scour depth did include scour created from piers or pile bents, which could not be separated from the abutment scour. In the case of clear-water contraction scour in the overbank area of Piedmont bridges, the measured scour depth, in general, represented scour created from the contraction alone and did not include local pier scour.

After collecting survey data, bed-material samples were taken at the low point of the scour hole and from the upstream unscoured area, and a grainsize distribution analysis was made on these samples. 


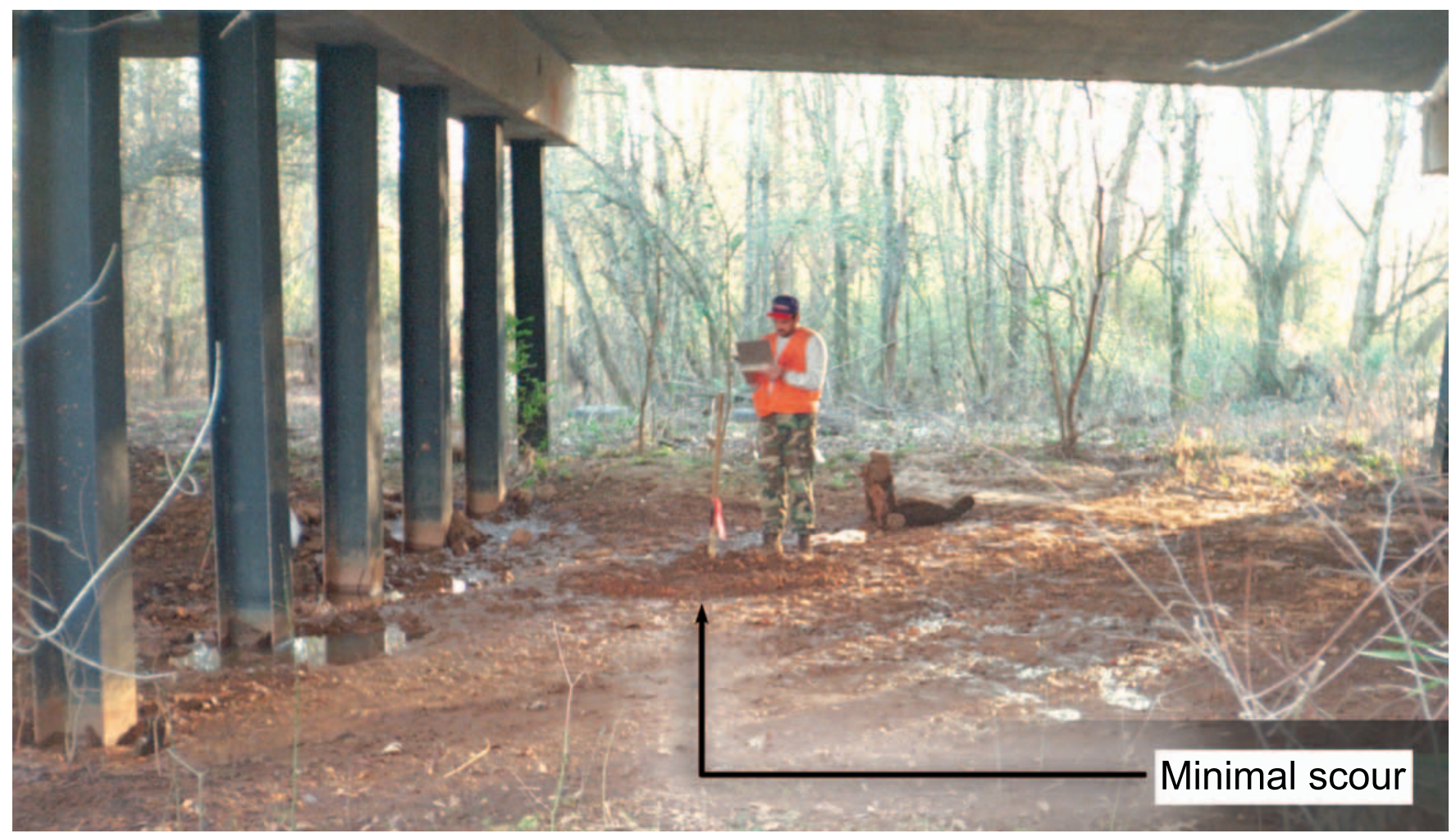

Figure 13. Example of minimal scour in the clayey soils of the Piedmont at Structure 047026300100 on Road S-263, crossing the Rocky River in Anderson County, South Carolina. (Photograph by the South Carolina District, U.S. Geological Survey, 1997.)

Post-hole diggers or the PVC drive-tube sampler were used to collect the sediment samples. In the clayey overbanks of the Piedmont, infill of scour holes by washed deposits is minimal and typically can be considered nonexistent. The amount of infill was determined by visual inspection of the scour hole and the material obtained from the bed samples. Pictures, sketches, and general descriptions of sites were made as needed.

\section{Flow Model Data}

In this study, 105 bridges had previously developed WSPRO (Shearman, 1990) models from the level 2 bridge-scour study. However, 41 bridges had not previously been studied, so appropriate field data were collected to develop the WSPRO model at these sites. Data included cross-section surveys along the bridge faces, road grade, and at appropriate locations upstream and (or) downstream from the bridge; collection of bridge geometry; and estimates of channel and floodplain roughness coefficients.

\section{Sediment Samples}

During the data-collection phase of the study, the analysis of grain-size distributions for sediment samples was limited to grain sizes greater than or equal to $0.062 \mathrm{~mm}$. This is the break point between the sand and silt/clay soils. For most Coastal Plain sites, this analysis was adequate for defining the median grain size $\left(\mathrm{D}_{50}\right)$. However, this size was occasionally inadequate for clayey Piedmont soils where the $\mathrm{D}_{50}$ can be smaller than $0.062 \mathrm{~mm}$. At such sites, the $\mathrm{D}_{50}$ was assumed equal to $0.062 \mathrm{~mm}$ and clear-water contraction scour was computed for this grain size. In an attempt to better understand and define the clay content of Piedmont soils, revisits were made to all Piedmont sites and a second grab sample was obtained and analyzed for the full range of grain size. (In this report, the first sample is referred to as the initial or original sediment sample, and the revisit sample is called the second sample.) 
In figure 14 , the $\mathrm{D}_{50}$ of the original sample is compared with that of the second sample. Although the second set of samples was obtained in close proximity to the original sample, there was often poor agreement in sediment size, and differences sometimes varied by an order of magnitude. This discrepancy in grain size, between multiple samples at the same site, highlights the nonhomogeneity of floodplain soils and indicates that grain-size analyses should be viewed with caution. (Because of this discrepancy, results obtained from scour-predicting equations that use $\mathrm{D}_{50}$ as an explanatory variable, also should be viewed with caution.) Although the results of the grain-size analyses in this study may be useful in obtaining a general understanding of soil conditions, it is questionable whether soil variables, such as the $\mathrm{D}_{50}$ obtained from grab samples are accurate representations of sediment characteristics that will allow for strong distinction of soils between various sites.

\section{Contraction Scour in the Abutment Area}

When assessing total theoretical scour at abutments, HEC-18 (Richardson and Davis, 1995) considers the various components that create scour to be independent and additive. Therefore, to determine the total theoretical scour, the individual components of long-term streambed change, pier scour, contraction scour, and abutment scour, within the abutment area must be estimated and then summed. This approach, in part, stems from the difficulty in isolating the impact of the various scour components when they develop scour concurrently. Therefore, laboratory investigations typically have focused on understanding each scour component in isolation, necessitating the above approach for estimating total scour. Field observations, in conjunction with the theory of flow patterns at short contractions, indicate that this view of scour in the abutment area is inappropriate.

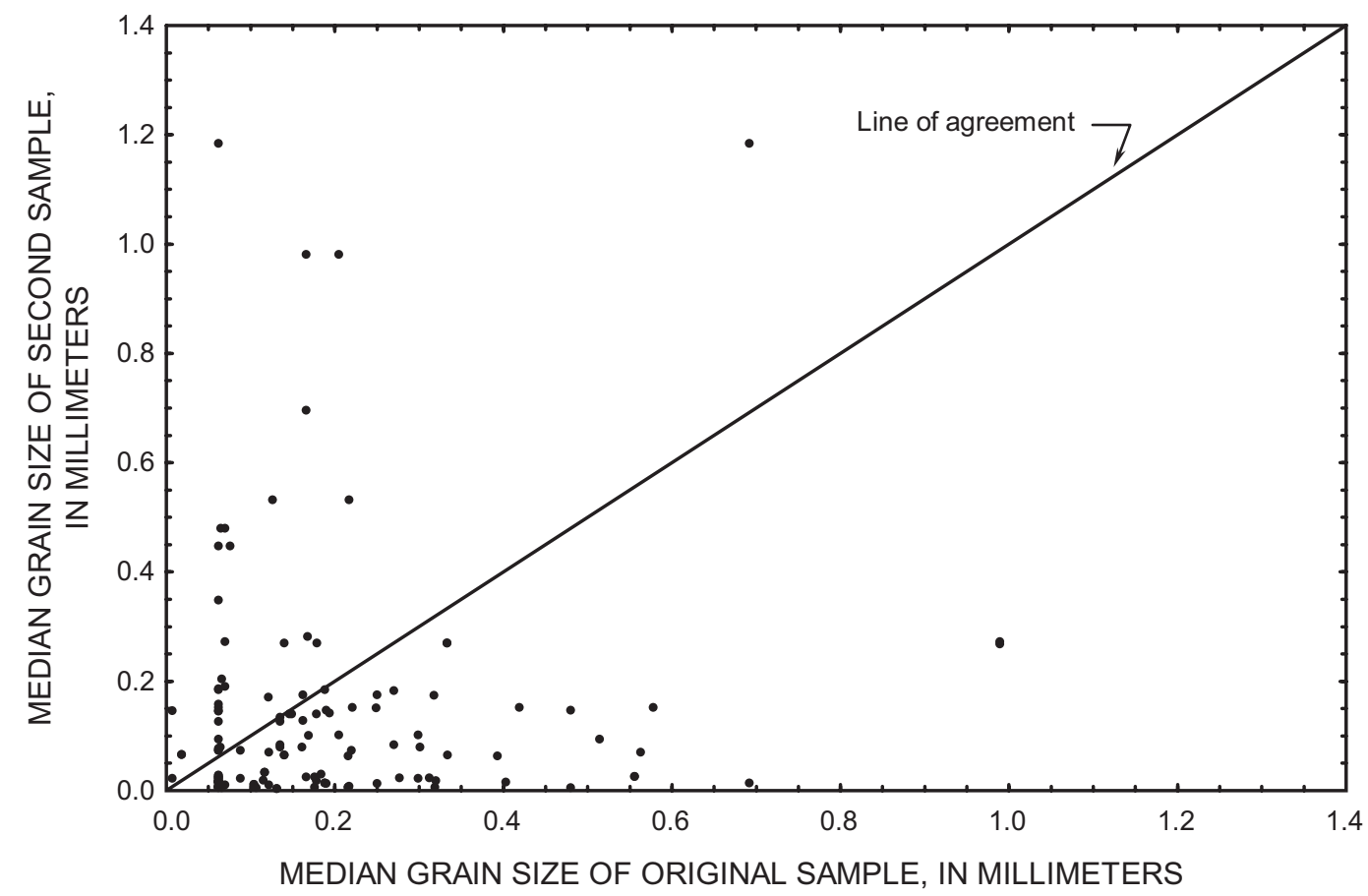

Figure 14. Comparison of median grain size between the original and second sediment samples. 
Consideration of contraction and local abutment scour as independent and separate processes in the abutment area is a particular concern. The assessment of clear-water contraction scour is often based on the simplifying assumption of uniform flow distributions within a long contraction. Therefore, flow patterns within a contraction are assumed to be rectilinear and equations for predicting scour can be derived using the concept of critical bed-shear stress for rectilinear flow. (This was the procedure used to derive the Laursen (1963) clear-water contraction-scour equation.) With lateral distance from the abutment, flow patterns are approximately rectilinear and the assumptions used to develop Laursen's 1963 equation are more appropriate. In the vicinity of the abutment, however, flow patterns typically have severe flow curvature. This curvature promotes vortices, which are the primary mechanism for the development of scour in the abutment area (Dongol, 1993). Because rectilinear flow patterns in the abutment area are absent, it is reasonable to assume that scour produced by this flow pattern is absent as well. Therefore, total scour in an abutment area should consist of long-term streambed change, local abutment scour generated from the severely curved flow field, and local pier scour generated from piers within this same flow field. Contraction scour produced by rectilinear flow should not be considered a component of total scour within this area.

With respect to field observations of abutment scour in this study, contraction scour should not be viewed as a contributing component of scour. This can possibly be a point of confusion when comparing field data with various abutment-scour equations derived from laboratory data. Many laboratory investigations have sought to separate contraction scour from abutment scour by subtracting observed contraction scour that has occurred beyond the abutment area from the total observed scour depth at the modeled abutment. For example, laboratory investigations by Dongol (1993) measured contraction scour at the flume wall opposite from the abutment, and subtracted it from the total scour at the abutment in an attempt to isolate the scour created by the abutment alone. Flow patterns near the flume wall will largely be rectilinear in contrast to the curved flow field at the modeled abutment. Therefore, it is unreasonable to expect contraction scour generated by rectilinear flow near the flume wall to be duplicated near the abutment were flow patterns are distinctly different. The scour at the modeled abutment and the flume wall are created by distinct flow patterns that produce different scouring mechanisms, and the scour generated at the abutment should not be considered a combination of scour generated by these two mechanisms. This convention has been used in many laboratory investigations, however, and abutment-scour equations, such as the Froehlich (1989) equation, have been derived using data developed in this manner. This should be kept in mind when comparing various laboratory relations with the field data in this report. When assessing scour in the abutment area using techniques presented in this report, no adjustment for contraction scour in the abutment area is required.

\section{Pier Scour in the Abutment Area}

When collecting abutment-scour field data, it was often difficult to isolate pier scour from abutment scour. This was particularly true for deeper scour holes approximately $5 \mathrm{ft}$ or greater. (In general, pier scour was isolated and not included in the measurement of scour in the shallow abutment-scour holes.) In this study, there are 85 abutment-scour holes deeper than $5 \mathrm{ft}$ with scour hole widths ranging from 19 to $130 \mathrm{ft}$ (perpendicular to flow) and lengths ranging from 24 to $395 \mathrm{ft}$ (parallel to flow). Piers or pile bents located within these large scour holes generally showed no significant signs of local pier-scour holes distinct from the abutment-scour hole. Although it is reasonable to assume that the presence of the piers or pile bents may have contributed to the scour within the abutment-scour hole, there was no reference surface that would allow the distinction to be made between the local pier and abutment scour. Therefore, abutment-scour depths for the deeper scour holes in this study should be viewed as including scour effects generated from piers or pile bents within the scour hole.

Perhaps part of the reason why local pier scour holes were, in general, not detected in the deeper abutment-scour holes is that multiple-column bents with widths ranging from 0.8 to $2.3 \mathrm{ft}$ were the most common type of bridge support found in this study (fig. 15). These small column widths tend to cause relatively minor amounts of scour that may go undetected within the larger abutment-scour holes. In this study, 85 percent of the bridge sites have multiple-column bents with column widths $\leq 2.3 \mathrm{ft}$ (fig. 15). Although the multiplecolumn bents may only have a minor contribution to the total scour at a given abutment, the field measurements were determined at the lowest point of the scour hole and, therefore, should include their effect. 


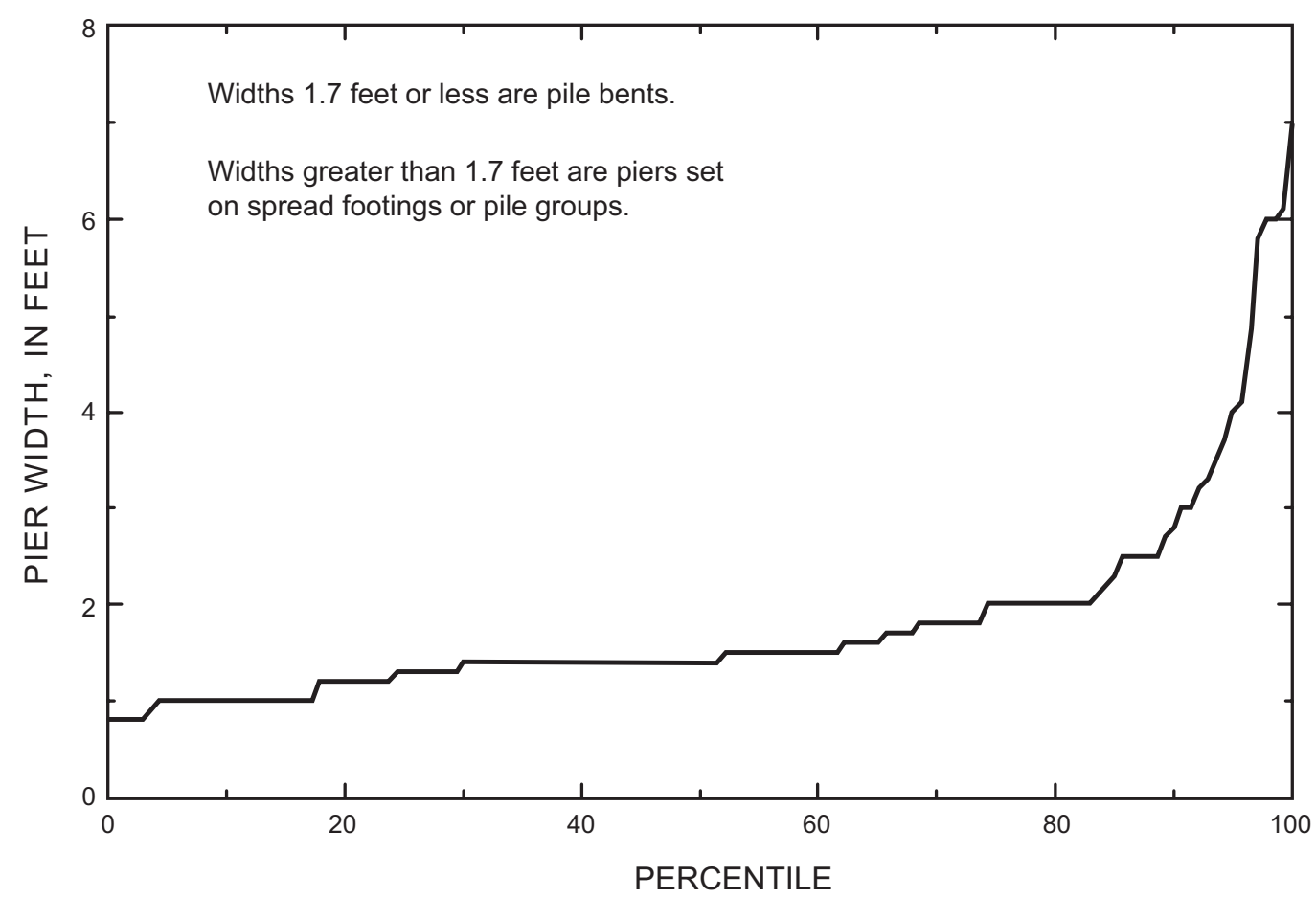

Figure 15. Percentile plot for the maximum pier or pile width for bridge-scour study sites in the Piedmont and Coastal Plain of South Carolina.

The location of a pier or multiple-column bent within a given abutment-scour hole will in some measure indicate the impact the pier has had on the total scour within the abutment area. Because the impact of local pier scour is typically confined to the close proximity of the pier, it seems reasonable to assume that a pier or multiple-column bent located at the low point of an existing abutment-scour hole creates the greatest impact on the total scour. Figure 16 gives an example of a pile bent located at the low point of the scour hole. In contrast, a pier or multiple-column bent located on the slope of an existing scour hole (fig. 17) is likely to have less impact on the total scour. The bridge-scour database included with this report indicates whether a pier or pile bent is located at the low point of the abutment-scour hole. In addition, 80 of the 146 bridge sites have scour-hole contour plots that indicate where piers or pile bents are located in relation to the measured scour. This information can be reviewed to gain understanding of the impact of pier scour on total abutment scour at a given site.

\section{ESTIMATING HYDRAULIC DATA}

As noted previously, data collected for this study reflect maximum clear-water scour depths for the life of a bridge rather than scour produced by a unique flow event. The limitation of such data is that observed scour cannot be associated with the hydraulic conditions that produced the scour. Because many of the theoretical scour equations are driven by hydraulic properties, such as flow depth and flow velocity, direct verification of these equations was limited in this study. In an attempt to minimize this limitation, the one-dimensional step-backwater model, WSPRO (Shearman, 1990) was used for each bridge to gain insights about hydraulic conditions during large flows. Because the magnitude of large floods at most of these sites is unknown, the 100-year flow was modeled as a common flood condition. In addition, known maximum historic flows at 35 sites were modeled. Hydraulic data generated from WSPRO were used in the theoretical scour equations to make a limited comparison of theoretical and observed scour. 


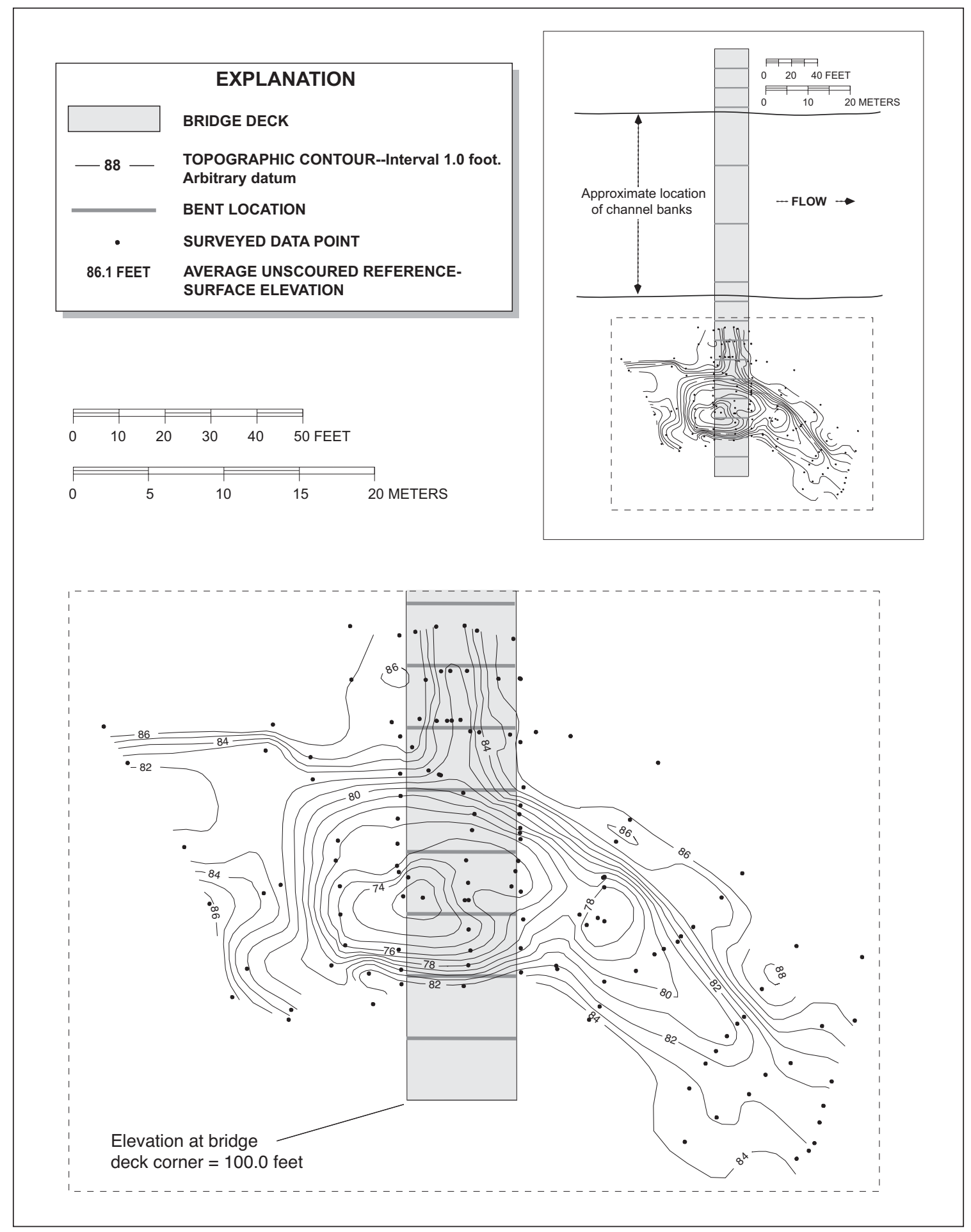

Figure 16. Example of pile bent located at the low point of a scour hole at Structure 367008100200 on Road S-81, crossing the Enoree River in Newberry County, South Carolina, April 7, 1997. 


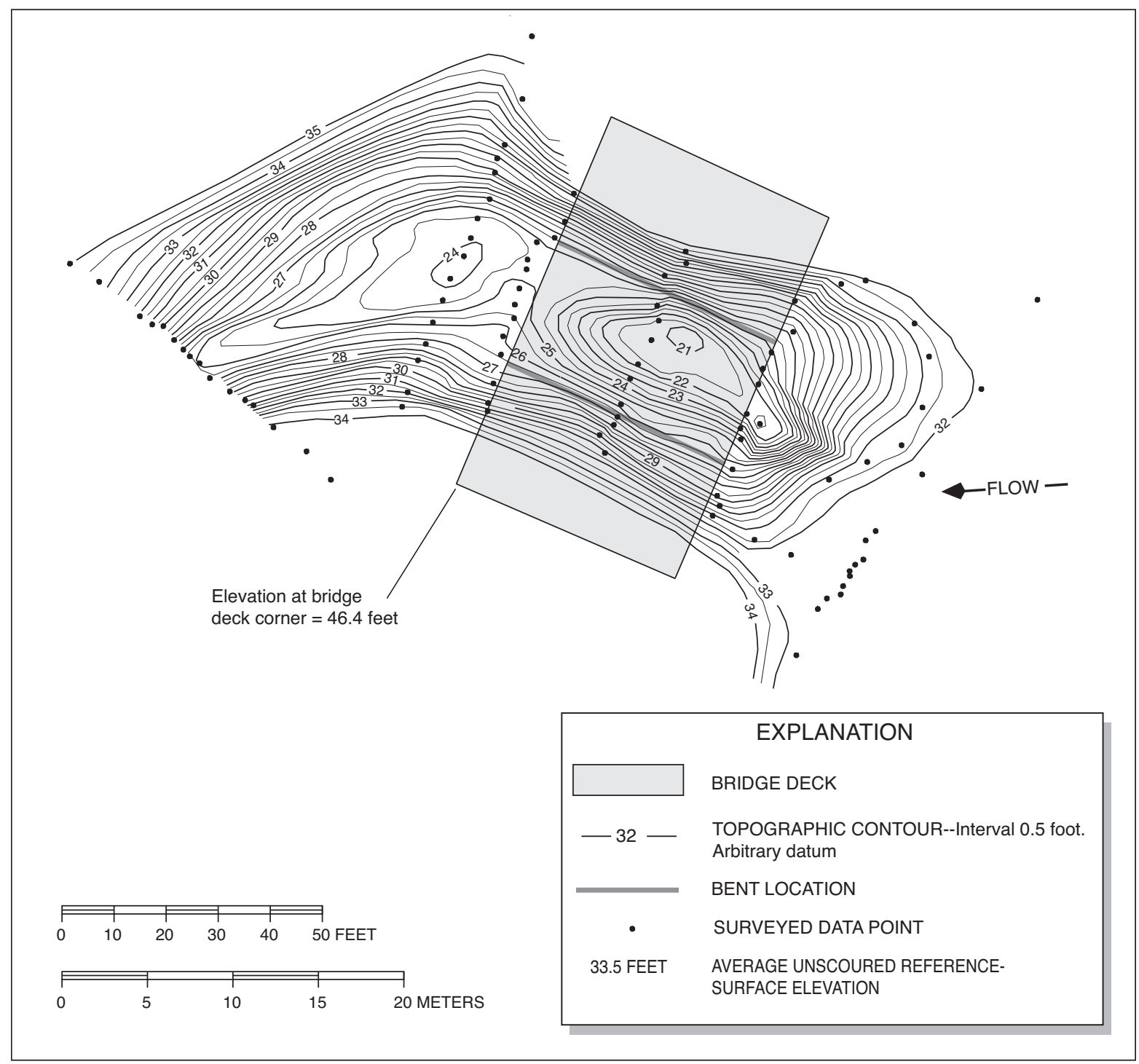

Figure 17. Example of pile bent located on the side of a scour hole at Structure 152002100300 on U.S. Route 21, crossing Sandy Run Creek in Colleton County, South Carolina, December 18, 1996.

Hydraulic properties from WSPRO, along with theoreticalscour properties, were entered in a database and these data, along with field observations, were used to investigate relations that may help explain scour in South Carolina.

\section{Development of WSPRO Models}

WSPRO models (Shearman, 1990) for 105 bridge sites had been developed previously in the level 2 bridge-scour study and were used in this investigation. An additional 41 WSPRO models were developed for sites not included in the level 2 study. These models typically used only the minimal cross sections (exit, full valley, bridge, and approach) required by WSPRO to analyze flow through a bridge. If the floodplain was relatively uniform in width, one surveyed cross section was used as a template to represent the exit, full valley, and approach cross sections. If sharp changes in floodplain widths or channel slopes occurred near a bridge, an attempt usually was made to incorporate these features into the WSPRO model by synthesizing cross sections from topographic maps and surveyed data. Surveyed data at the upstream or downstream bridge face were used to represent the bridge cross section in the WSPRO model. Manning's roughness coefficients 
for conditions at the time of the site visit were estimated from field observations and incorporated into the models. For most sites, no gage or historic flood data were available. Therefore, the starting watersurface elevation for the models was determined by slope conveyance. Where flow data were available, high-water marks or gage data were used to estimate starting water-surface elevations. When necessary, cross sections were synthesized at downstream controls as evident from topographic maps.

The hydraulic models developed for this study used limited field data and simplifying assumptions. Results from the models will likely have some error associated with them and, therefore, the solutions should be viewed as approximate rather than precise. Also, observed field conditions at the time of model development might not reflect the conditions that produced the scour. Of particular concern are forested floodplains that may have been clear-cut in the past and pastures that may have been forested or overgrown. Such changes in land cover can significantly affect Manning's roughness coefficients which, in turn, can affect the estimate of hydraulic variables. These issues should be kept in mind when reviewing hydraulic properties (such as embankment length, flow velocity, and flow depth) generated from the WSPRO models.

When designing a new bridge to withstand scour, the theoretical scour at that bridge typically is estimated using pre-scour hydraulic conditions. To follow this pattern, the theoretical scour computed for each site was based on pre-scour hydraulics. In many cases, the existing scour hole at a bridge significantly changed the hydraulics from the pre-scour conditions. To estimate pre-scour hydraulics at these sites, the WSPRO model (Shearman, 1990) was adjusted to reflect conditions prior to scour. The typical modification required changing the ground elevations at the bridge cross section to represent pre-scour conditions. Bridge plans, field data, and judgment were used to make these adjustments. Where scour depths were small (approximately $3 \mathrm{ft}$ or less) and the areal extent of scour was limited, no adjustments were made to the WSPRO models. Because scour depths were small at most Piedmont sites, no model adjustments were usually required. Models of Coastal Plain sites, however, were usually modified because of the larger scour depths.

To obtain an understanding of the impact of large scour holes on bridge hydraulics, WSPRO models (Shearman, 1990) reflecting the existing scour holes also were developed. To determine bridge hydraulics, the WSPRO model requires a cross section at the downstream bridge face. In many cases, the deepest part of a scour hole did not coincide with this location. Therefore, to estimate the change in hydraulics induced by a scour hole, the scour-hole geometry was superimposed on the bridge cross section. This was typically accomplished by hand projecting the survey data at the deepest part of the scour hole onto the downstream bridge face. Because scour-hole geometry is commonly complex and the primary axis of the hole may be skewed to the bridge face, judgment was often required to accomplish this task. Because scour depths were small at most Piedmont sites, post-scour hydraulics were assumed to be the same as pre-scour hydraulics. Exceptions to this were the Piedmont sites with large abutment-scour holes. Post-scour WSPRO models were developed at most Coastal Plain sites because large scour holes typically exist at these bridges.

\section{Estimates of Hypothetical Flows}

The hypothetical flows that were used in the WSPRO model were the 100-year flow and an index flow having a recurrence interval equal to the age of the bridge. The 100-year flow is recommended in HEC-18 (Richardson and Davis, 1995) as a standard condition for estimating theoretical scour and was used as a common flow at all sites. Because older bridges have a higher probability of having experienced large, scourproducing flows, bridge age might have a significant influence on scour depth. To incorporate the influence of bridge age, an index flow having a recurrence interval equal to the bridge age was determined for each site. For example, a 20-year old bridge was assigned an index flow equal to the 20-year flow. Theoretical scour based on the hypothetical flows was compared with the observed scour to assess the reasonableness of the HEC-18 methods. In addition, the hydraulic- and theoretical-scour data generated with the hypothetical flows were used to investigate relations that might help explain scour in South Carolina. Initial comparison indicated large discrepancies between the index flows based on bridge age and known maximum historic flows at selected sites. The index flows were often much lower than the maximum historic flows. Therefore, investigations of relations within the database focused primarily on data produced with the 100-year flow and the maximum historic flows.

The 100-year flow and index flow for rural basins were computed using the flood-frequency equations and 
methods presented in Guimaraes and Bohman (1992). Where the recurrence interval of the index flow did not directly correspond with the recurrence interval of the flood-frequency equations (2-, 5-, 10-, 25-, 50-, or 100year flow), estimates of the index flows were obtained by interpolating between the flood-frequency equations. Rural flows in the high-flow region of the Piedmont (Guimaraes and Bohman, 1992) (fig. 1) were estimated using the North Carolina Piedmont rural floodfrequency equations (Gunter and others, 1987) as recommended in an unpublished USGS study (C.L. Sanders, U.S. Geological Survey, written commun., November 1993). This study showed that the North Carolina equations tend to better represent the limited stream-gage data in the high-flow region. The North Carolina Piedmont equations give larger peak-flow magnitudes than the South Carolina equations.

For example, the 100-year peak-flow equation for the
Piedmont of South Carolina (Guimaraes and Bohman, 1992) is:

$$
474 \mathrm{~A}^{0.63}
$$

where $\mathrm{A}$ is the drainage area in square miles.

The 100-year peak-flow equation for the North Carolina Piedmont (Gunter and others, 1987) is:

$$
719 \mathrm{~A}^{0.643} \text {. }
$$

The difference between these equations is significant. Because the recommendation to use the North Carolina equations is based on limited field data, the estimated peak flows for the high-flow region may contain some error. This should be kept in mind when reviewing sites in this region. Twenty-one bridge sites in the current study were influenced by the high-flow region (table 2). Flows for urban drainage basins with an impervious area greater than 10 percent of the basin were computed

Table 2. Bridge-scour study sites influenced by the high-flow region in the Piedmont of South Carolina

[SCDOT, South Carolina Department of Transportation; S.C., South Carolina Route;

\begin{tabular}{|c|c|c|c|c|}
\hline County & Road & Stream & $\begin{array}{l}\text { SCDOT } \\
\text { structure } \\
\text { number }\end{array}$ & $\begin{array}{l}\text { Reference } \\
\text { number } \\
\text { (fig. } 1 \\
\text { and } \\
\text { app. B) }\end{array}$ \\
\hline Cherokee & S.C. 5 & Buffalo Creek & 114000500200 & 12 \\
\hline Cherokee & S-348 & Buffalo Creek & 117034800100 & 13 \\
\hline Chester & $\mathrm{I}-77$ & Fishing Creek & 121007710700 & 14 \\
\hline Chester & S.C. 9 & Turkey Creek & 124000900200 & 15 \\
\hline Chester & S.C. 9 & Fishing Creek & 124000901100 & 16 \\
\hline Chester & S.C. 72 & Sandy River & 124007200200 & 17 \\
\hline Chester & S.C. 97 & Turkey Creek & 124009700100 & 18 \\
\hline Chester & S.C. 97 & Rocky Creek & 124009700800 & 19 \\
\hline Chester & S.C. 215 & Sandy River & 124021500200 & 20 \\
\hline Chester & S.C. 223 & Fishing Creek & 124022300100 & 21 \\
\hline Chester & S.C. 901 & Rocky Creek & 124090100200 & 22 \\
\hline Fairfield & I-77 & Little Wateree Creek & 201007710600 & ${ }^{\mathrm{a}} 45$ \\
\hline Fairfield & I-77 & Big Wateree Creek & 201007710700 & 46 \\
\hline Fairfield & U.S. 21 & Dutchmans Creek & 202002100200 & ${ }^{\mathrm{a}} 47$ \\
\hline Fairfield & U.S. 21 & Big Wateree Creek & 202002100400 & 48 \\
\hline Fairfield & S.C. 200 & Wateree Creek & 204020000500 & 49 \\
\hline York & S.C. 97 & Bullocks Branch & 464009700300 & 140 \\
\hline York & S.C. 322 & Fishing Creek & 464032200300 & 141 \\
\hline York & S.C. 322 & Tools Fork Creek & 464032200500 & 142 \\
\hline York & S.C. 557 & Crowders Creek & 464055700200 & 143 \\
\hline York & S-721 & Taylors Creek & 467072100100 & 144 \\
\hline
\end{tabular}
S, Secondary Road; I, Interstate Highway; U.S., United States Route]

${ }^{a}$ Site is not in the high-flow region, but flows at the site are thought to be similar to or influenced by the high-flow region. 
using the urban-runoff equations presented in Bohman (1992). Two sites were found to have impervious areas exceeding 10 percent (table 3 ).
USGS gaging station data (gaging station numbers 02175450, 02175500, and 02176500, fig. 5.) The range of recurrence intervals for the estimated flows was from 60 to greater than 100 years, with eight sites exceeding the 100-year flow magnitude. The three

Table 3. Bridge-scour study sites with impervious area exceeding 10 percent of the drainage-basin area [SCDOT, South Carolina Department of Transportation; $\mathrm{mi}^{2}$, square miles; S.C., South Carolina Route]

\begin{tabular}{lllcccc} 
County & Road & Stream & $\begin{array}{c}\text { SCDOT structure } \\
\text { number }\end{array}$ & $\begin{array}{c}\text { Drainage } \\
\text { area } \\
\left.\mathbf{( m i}^{\mathbf{2}}\right)\end{array}$ & $\begin{array}{c}\text { Impervious } \\
\text { area of } \\
\text { drainage } \\
\text { basin, } \\
\text { in percent }\end{array}$ & $\begin{array}{c}\text { Reference } \\
\text { number } \\
\text { (fig. 1 } \\
\text { and } \\
\text { app. B) }\end{array}$ \\
Spartanburg & S.C. 146 & Enoree River & 424014600100 & 127 & 13 & 127 \\
Spartanburg & S.C. 296 & Enoree River & 424029600100 & 119 & 14 & 128 \\
\hline
\end{tabular}

\section{Historical Flows}

Although most bridge sites in this study had no record of maximum historic flows, these data were available at or near 35 sites and were used to estimate maximum flows during the life of the bridge. The maximum historic flows were estimated using data obtained from USGS gaging stations or from floods documented by the USGS using indirect methods for flow computation. Particular focus was given to several floods documented in the Coastal Plain and the Piedmont. These maximum historic flows were used in the WSPRO model (Shearman, 1990) to estimate hydraulic conditions during those floods. The hydraulic variables were then used to estimate theoretical scour for the maximum flows and compared with the observed scour. In addition, the hydraulic- and theoretical-scour data generated with the maximum historic flows were used to investigate relations that might help explain scour in South Carolina.

\section{Flood of October 1992}

In October 1992, approximately 9 in. of rain fell in 24 hours over Allendale, Bamberg, Colleton, and Hampton Counties (fig. 6). This storm produced extensive flooding with flow magnitudes exceeding the 100-year flow (T.H. Lanier, U.S. Geological Survey, written commun., December 1993). The USGS estimated peak flows at 11 sites within this region, 8 being determined by indirect flow computations and 3 from gaging stations had periods of record in 1992 ranging from 29 to 41 years, and the flows for this event were the peak flows for the period of record. (Stations 02175500 and 02176500 are currently active (2002) and the flows recorded in October 1992 remain the peak flow of record.) Based on these gaging station records, it was assumed that the flows computed by indirect measurements at the ungaged sites would most likely represent the maximum flow during the life of the bridge. Seven of the 11 sites were used in this study and the maximum historic flow at an additional site was estimated by interpolating these data (table 4).

\section{Flood of August 1995}

In August 1995, extensive flooding occurred in the Piedmont of South Carolina when Tropical Storm Jerry produced 8 to $20 \mathrm{in}$. of rainfall over a 4-day period (fig. 6). The USGS estimated peak flows at 26 sites within this region, and the recurrence intervals for the estimated flows ranged from 10 to greater than 100 years (A.W. Caldwell, U.S. Geological Survey, written commun., January 1996). The heaviest flooding occurred on the Reedy, South Tyger, and Enoree Rivers (fig. 6), and focus was given to these rivers for collecting field data. The USGS estimated peak flows at three locations along the Reedy River, at three locations along the South Tyger River and at five locations along the Enoree River (table 5). 
Table 4. Estimated peak flows from the October 1992 flood at bridge-scour study sites in the lower Coastal Plain of South Carolina

$\left[\mathrm{mi}^{2}\right.$, square miles; $\mathrm{ft}^{3} / \mathrm{s}$, cubic feet per second; S-, Secondary Road; >, greater than; S.C., South Carolina Route; U.S., United States Route]

\begin{tabular}{|c|c|c|c|c|c|c|c|}
\hline County & Road & Stream & $\begin{array}{c}\text { Drainage } \\
\text { area } \\
\left(\mathrm{mi}^{2}\right)\end{array}$ & $\begin{array}{l}\text { Method for } \\
\text { estimating } \\
\text { peak flow }\end{array}$ & $\begin{array}{c}\text { Discharge } \\
\left(\mathrm{ft}^{3} / \mathrm{s}\right)\end{array}$ & $\begin{array}{c}\text { Recurrence } \\
\text { interval } \\
\text { (years) }\end{array}$ & $\begin{array}{c}\text { Reference } \\
\text { number } \\
\text { (fig. 6; } \\
\text { app. B) }\end{array}$ \\
\hline Allendale & S-107 & Gaul Branch & 8.5 & Indirect measurement & 2,240 & $>100$ & 8 \\
\hline Allendale & S.C. 3 & King Creek & 17.2 & Indirect measurement & 1,560 & 70 & 5 \\
\hline Allendale & S.C. 3 & Gaul Creek & 17.9 & Indirect measurement & 4,320 & $>100$ & 6 \\
\hline Hampton & S-13 & Whippy Swamp & 134 & Indirect measurement & 10,100 & $>100$ & 69 \\
\hline Allendale & S-21 & Coosawhatchie River & 48.1 & Indirect measurement & 11,900 & $>100$ & 7 \\
\hline Hampton & S.C. 363 & Coosawhatchie River & 124 & Interpolation & 5,380 & 100 & 68 \\
\hline Hampton & U.S. 601 & Coosawhatchie River & 203 & Stage-flow rating & $8,800^{*}$ & $>100$ & 67 \\
\hline Jasper & S-87 & Coosawhatchie River & 382 & Indirect measurement & 14,100 & $>100$ & 83 \\
\hline
\end{tabular}

*A discharge of $8.200 \mathrm{ft}^{3} / \mathrm{s}$ was inadvertently used in this study to represent the peak flow for the October 1992 flood at the U.S. Route 601 crossing of the Coosawatchie River. This is a 7 percent reduction in the correct peak flow of $8,800 \mathrm{ft}^{3} / \mathrm{s}$ and should not produce significant errors in the WSPRO (Shearman, 1990) model and theoretical scour computations of this site.

Table 5. Estimated peak flows at selected U.S. Geological Survey gaging stations and ungaged sites for the August 1995 flood along the Reedy, South Tyger, and Enoree Rivers in South Carolina

[USGS, U.S. Geological Survey; $\mathrm{mi}^{2}$, square miles; $\mathrm{ft}^{3} / \mathrm{s}$, cubic feet per second; S.C., South Carolina; >, greater than]

\begin{tabular}{|c|c|c|c|c|c|c|}
\hline $\begin{array}{l}\text { USGS gaging } \\
\text { station number } \\
\text { (fig. 5) }\end{array}$ & Station name & $\begin{array}{l}\text { Period of } \\
\text { record at } \\
\text { time of } \\
\text { flood }\end{array}$ & $\begin{array}{c}\text { Drainage } \\
\text { area } \\
\left(\mathrm{mi}^{2}\right)\end{array}$ & $\begin{array}{l}\text { Method for } \\
\text { determining } \\
\text { peak flow }\end{array}$ & $\begin{array}{c}\text { Discharge } \\
\left(\mathrm{ft}^{3} / \mathrm{s}\right)\end{array}$ & $\begin{array}{c}\text { Recurrence } \\
\text { interval } \\
\text { (years) }\end{array}$ \\
\hline 02164000 & Reedy River near Greenville, S.C. & $1942-1995$ & 48.6 & Stage-flow rating & ${ }^{a} 5,400$ & ${ }^{\mathrm{b}}$ Urban \\
\hline 02164110 & Reedy River near Fork shoals, S.C. & 1939-1995 & 104 & Stage-flow rating & 8,200 & ${ }^{\mathrm{b}}$ Urban \\
\hline 02165000 & Reedy River near Ware Shoals, S.C. & 1939-1995 & 236 & Stage-flow rating & ${ }^{\mathrm{a}} 9,870$ & 20 \\
\hline Ungaged & South Tyger River near Duncan, S.C. & No record & 91.8 & $\begin{array}{c}\text { Indirect } \\
\text { measurement }\end{array}$ & 13,900 & $>100$ \\
\hline $\begin{array}{c}02158500 \\
\text { (discontinued) }\end{array}$ & South Tyger River near Reidville, S.C. & $1935-1967$ & 106 & Stage-flow rating & ${ }^{c} 9,650$ & $>100$ \\
\hline $\begin{array}{c}02159000 \\
\text { (discontinued) }\end{array}$ & South Tyger River near Woodruff, S.C. & 1934-1971 & 174 & Stage-flow rating & ${ }^{c} 16,500$ & $>100$ \\
\hline 02160326 & Enoree River at Pelham, S.C. & 1993-1995 & 84.2 & $\begin{array}{c}\text { Indirect } \\
\text { measurement }\end{array}$ & a 11,300 & $>100$ \\
\hline Ungaged & Enoree River near Woodruff, S.C. & No record & 177 & $\begin{array}{c}\text { Indirect } \\
\text { measurement }\end{array}$ & 65,000 & $>100$ \\
\hline 02160390 & Enoree River near Woodruff, S.C. & 1993-1995 & 249 & $\begin{array}{c}\text { Indirect } \\
\text { measurement }\end{array}$ & ${ }^{\mathrm{a}} 50,400$ & $>100$ \\
\hline $\begin{array}{c}02160500 \\
\text { (discontinued) }\end{array}$ & Enoree River at Enoree, S.C. & $1930-1993$ & 307 & Stage-flow rating & ${ }^{\mathrm{c}} 43,800$ & $>100$ \\
\hline 02160700 & Enoree River at Whitmire, S.C. & 1974-1995 & 444 & Stage-flow rating & ${ }^{a} 31,200$ & $>100$ \\
\hline
\end{tabular}

${ }^{a}$ Peak flow for period of record.

${ }^{\mathrm{b}}$ Upper part of basin is urbanized, but flows exceeded the magnitude for the 100-year rural flows.

${ }^{\mathrm{c}}$ Flow exceeded peak flow for period of record. 
Based on the gaging station records for the Reedy, South Tyger, and Enoree Rivers, it was assumed that the flows during the 1995 flood would most likely represent the maximum historic flow for most bridges presently located on these rivers. Exceptions were in the lower part of the Reedy River where recurrence intervals dropped to 20 years. After post-flood reconnaissance, two bridges on the Reedy River, three bridges on the South Tyger River and seven on the Enoree River were selected for inclusion in this study (table 6). Sites with unknown peak flows for the 1995 flood were estimated by prorating known peak flows by drainage area. [Peak flows at S.C. Route 146 and S.C. Route 296 crossing the Enoree River (reference numbers 127 and 128, respectively, appendix B) were not estimated.] Most of these estimates appear reasonable; however, Road S-81 crossing the Enoree River is 10 mi downstream from the last flow measurement on the river (USGS gaging station 02160700, Enoree River at Whitmire, S.C., fig. 5), and the extrapolated flood flow might be too low. All flow measurements along the Enoree River from the 1995 flood exceeded the 100-year flow, but flows began to decrease at a drainage area of $177 \mathrm{mi}^{2}$ in the downstream direction (table 5). This decreasing trend was used to extrapolate flows downstream from gaging station 02160700 (fig. 5), causing flows to eventually fall below the 100-year flow magnitude. Based on the fact that measured flows at five sites along the Enoree River exceeded the 100year flow and that the extrapolation is significantly beyond the measured data, flows at Road S-81 might have been higher than the estimated $23,400 \mathrm{ft}^{3} / \mathrm{s}$.

\section{Flood of September 1999}

In September 1999, rainfall from Hurricane Floyd produced extensive flooding along the Waccamaw River in Horry County, South Carolina (fig. 6), where flow magnitudes exceeded the 100-year flow. Peak flows were estimated at three USGS gaging stations along the Waccamaw River (table 7 and fig. 5), and flows at each gage were the peak for the period of record. Based on the gaging station records, it was assumed that flows along the Waccamaw River during the 1999 flood would most likely represent the maximum historic flow for existing structures. After postflood reconnaissance, three multiple-bridge crossings on the Waccamaw River, encompassing eight bridges, were selected for inclusion in the current bridge-scour study (table 8). (One bridge on the Waccamaw River was subsequently removed from the study because of disturbance to the floodplain from construction equipment.) Peak flows along the Waccamaw River were estimated by prorating peak gage flows by drainage area.

This flood also influenced the Pee Dee and Little Pee Dee Rivers. Although flows did not exceed the 25-year magnitude during the 1999 flood, long-term gages indicate that flows near the 25-year flow magnitude have occurred on both rivers (table 9). One multiple-bridge crossing with six bridges on the

Table 6. Estimated peak flows at bridge-scour study sites for the August 1995 flood in the Piedmont of South Carolina $\left[\mathrm{mi}^{2}\right.$, square miles; $\mathrm{ft}^{3} / \mathrm{s}$, cubic feet per second; S-, Secondary Road; U.S., United States Route; >, greater than; S.C., South Carolina Route]

\begin{tabular}{|c|c|c|c|c|c|c|c|}
\hline County & Road & Stream & $\begin{array}{c}\text { Drainage } \\
\text { area } \\
\left(\mathrm{mi}^{2}\right)\end{array}$ & $\begin{array}{l}\text { Method for } \\
\text { estimating } \\
\text { peak flow }\end{array}$ & $\begin{array}{c}\text { Discharge } \\
\left(\mathrm{ft}^{3} / \mathrm{s}\right)\end{array}$ & $\begin{array}{c}\text { Recurrence } \\
\text { interval } \\
\text { (years) }\end{array}$ & $\begin{array}{l}\text { Reference } \\
\text { number } \\
\text { (fig. 6; } \\
\text { app. B) }\end{array}$ \\
\hline Greenville & S-68 & Reedy River & 173 & Extrapolation & 9,530 & 35 & 64 \\
\hline Laurens & S-36 & Reedy River & 236 & Stage-flow rating & 9,870 & 20 & 91 \\
\hline Spartanburg & U.S. 29 & South Tyger River & 76.0 & Extrapolation & 6,500 & 50 & 125 \\
\hline Spartanburg & $S-62$ & South Tyger River & 91.8 & Indirect measurement & 13,900 & $>100$ & 129 \\
\hline Spartanburg & S-242 & South Tyger River & 94.4 & Extrapolation & 8,400 & $>100$ & 131 \\
\hline Spartanburg & S-118 & Enoree River & 186 & Extrapolation & 64,200 & $>100$ & 130 \\
\hline Laurens & S-263 & Enoree River & 249 & Indirect measurement & 50,400 & $>100$ & 94 \\
\hline Laurens & S-112 & Enoree River & 256 & Extrapolation & 50,000 & $>100$ & 93 \\
\hline Laurens & S.C. 49 & Enoree River & 307 & Stage-flow rating & 43,800 & $>100$ & 88 \\
\hline Union & S.C. 56 & Enoree River & 371 & Extrapolation & 37,500 & $>100$ & 134 \\
\hline Union & S-22 & Enoree River & 395 & Extrapolation & 35,700 & $>100$ & 135 \\
\hline Newberry & S-81 & Enoree River & 677 & Extrapolation & ${ }^{a} 23,400$ & 40 & 112 \\
\hline
\end{tabular}

${ }^{\text {a }}$ Extrapolated discharge is significantly beyond limits of measured flow data and may be too low. 
Table 7. Estimated peak flows at selected U.S. Geological Survey gaging stations for the September 1999 flood along the Waccamaw River in North Carolina and South Carolina

[USGS, U.S. Geological Survey; $\mathrm{mi}^{2}$, square miles; $\mathrm{ft}^{3} / \mathrm{s}$, cubic feet per second; N.C., North Carolina; >, greater than; S.C., South Carolina]

\begin{tabular}{|c|c|c|c|c|c|}
\hline $\begin{array}{l}\text { USGS gaging } \\
\text { station } \\
\text { number } \\
\text { (fig. 5) }\end{array}$ & Station name & Period of record & $\begin{array}{c}\text { Drainage } \\
\text { Area } \\
\left(\mathrm{mi}^{2}\right)\end{array}$ & $\begin{array}{l}\text { Discharge } \\
\left(\mathrm{ft}^{3} / \mathrm{s}\right)\end{array}$ & $\begin{array}{c}\text { Recurrence } \\
\text { interval } \\
\text { (years) }\end{array}$ \\
\hline a 02109500 & Waccamaw River at Freeland, N.C. & 1940-1999 & 680 & $\mathrm{~b}_{31,200}$ & $>100$ \\
\hline 02110500 & Waccamaw River at Longs, S.C. & 1950-1999 & 1,110 & ${ }^{b} 28,200$ & $>100$ \\
\hline 02110704 & $\begin{array}{l}\text { Waccamaw River at Conway } \\
\text { Marina at Conway, S.C. }\end{array}$ & 1991-1999 & ${ }^{c} 1,420$ & $\mathrm{~b}_{24,800}$ & undetermined \\
\hline
\end{tabular}

\footnotetext{
${ }^{\text {a }}$ Site is located in North Carolina and is not shown on figure 5.

${ }^{\mathrm{b}}$ Peak flow for period of record.

${ }^{\mathrm{c}}$ Approximate drainage area; site tidally influenced at low stages.
}

Table 8. Estimated maximum historic flows for bridge-scour study sites along the Waccamaw, Pee Dee, and Little Pee Dee Rivers in South Carolina

$\left[\mathrm{mi}^{2}\right.$, square miles; $\mathrm{ft}^{3} / \mathrm{s}$, cubic feet per second; U.S., United States Route; S.C., South Carolina Route]

\begin{tabular}{|c|c|c|c|c|c|c|c|}
\hline County & Road & Stream & $\begin{array}{c}\text { Number of } \\
\text { bridges at } \\
\text { crossing }\end{array}$ & $\begin{array}{c}\text { Drainage } \\
\text { area } \\
\left(\mathrm{mi}^{2}\right)\end{array}$ & $\begin{array}{c}\text { Date of } \\
\text { maximum } \\
\text { historic flow }\end{array}$ & $\begin{array}{c}\text { Discharge } \\
\left(\mathrm{ft}^{3} / \mathrm{s}\right)\end{array}$ & $\begin{array}{c}\text { Recurrence } \\
\text { interval } \\
\text { (years) }\end{array}$ \\
\hline Florence & U.S. 76 & Pee Dee River & 2 & 8,830 & March 1979 & 103,000 & ${ }^{\mathrm{a}}$ Regulated \\
\hline Horry & S.C. 22 & Waccamaw River & 4 & $\mathrm{~b}_{1,200}$ & September 1999 & 27,000 & ${ }^{\mathrm{c}}$ Tidally influenced \\
\hline Horry & U.S. 501 & Waccamaw River & 3 & $\mathrm{~b}_{1,420}$ & September 1999 & 24,000 & ${ }^{\mathrm{c}}$ Tidally influenced \\
\hline Horry & U.S. 501 By Pass & Waccamaw River & 1 & $\mathrm{~b}_{1,420}$ & September 1999 & 24,000 & ${ }^{\mathrm{c}}$ Tidally influenced \\
\hline Horry & U.S. 501 & Little Pee Dee River & 6 & 2,790 & October 1965 & 27,600 & 40 \\
\hline
\end{tabular}

${ }^{\mathrm{a}}$ The Pee Dee River is regulated making it difficult to assign a flood frequency at this location. However, if it is assumed that no regulation exists, the recurrence interval for this flow based on the gaging station record is 25 years.

${ }^{\mathrm{b}}$ Approximate drainage area only.

${ }^{\mathrm{c}}$ These sites are tidally influenced and therefore are not assigned a flood frequency. The historic flows at these bridges are believed to be the maximum historic flow for the life of the bridges. For purposes of this study, the maximum historic flows at these bridges also were assumed to be equal to the magnitude of the 100 -year flow.

Table 9. Estimated maximum historic flows at selected U.S. Geological Survey gaging stations along the Pee Dee and Little Pee Dee Rivers in South Carolina

[USGS, U.S. Geological Survey; $\mathrm{mi}^{2}$, square miles; $\mathrm{ft}^{3} / \mathrm{s}$, cubic feet per second; S.C., South Carolina]

\begin{tabular}{|c|c|c|c|c|c|c|}
\hline $\begin{array}{l}\text { USGS gaging } \\
\text { station number } \\
\text { (fig. 5) }\end{array}$ & Station name & $\begin{array}{l}\text { Period of } \\
\text { record }\end{array}$ & $\begin{array}{c}\text { Drainage } \\
\text { area } \\
\left(\mathrm{mi}^{2}\right)\end{array}$ & $\begin{array}{c}\text { Date of } \\
\text { maximum } \\
\text { historic flow }\end{array}$ & $\begin{array}{l}\text { Discharge } \\
\left(\mathrm{ft}^{3} / \mathrm{s}\right)\end{array}$ & $\begin{array}{c}\text { Recurrence } \\
\text { interval } \\
\text { (years) }\end{array}$ \\
\hline 02135000 & $\begin{array}{l}\text { Little Pee Dee River at Galivants } \\
\text { Ferry, S.C. }\end{array}$ & 1938-1999 & 2,790 & October 1965 & 27,600 & 40 \\
\hline 02131000 & Pee Dee River at Pee Dee, S.C. & $1942-1999$ & 8,830 & March 1979 & 103,000 & ${ }^{\mathrm{a}}$ Regulated \\
\hline
\end{tabular}

a The Pee Dee River is regulated making it difficult to assign a flood frequency at this location. However, if it is assumed that no regulation exists, then the recurrence interval for this flow based on the gage record is 25 years. 
Little Pee Dee River and one multiple-bridge crossing with two bridges on the Pee Dee River also were selected (table 8). The long-term gaging stations in table 9 are located at these crossings and provide data to estimate the maximum historic flow.

\section{DEVELOPMENT OF THEORETICAL BRIDGE-SCOUR DATABASE}

Theoretical scour was computed at each bridge for the 100-year flow, index flow, and, where available, maximum historic flow. Methods and equations described in HEC-18 (Richardson and Davis, 1995) were used to calculate theoretical pier, abutment, and contraction scour. The hydraulic variables required for these equations were obtained from the WSPRO model (Shearman, 1990). Computer programs were written to automate the extraction of hydraulic data from the WSPRO output files and to calculate theoretical scour. Theoretical scour depths and variables required to compute these depths are in a database available at https://pubs.er.usgs.gov/publication/wri034064.

\section{Theoretical Pier Scour}

Pile bents are a common foundation for bridges in South Carolina and were the primary foundation at approximately 70 percent of the bridges studied in this investigation (fig. 15). Pile bents consist of a row of piles driven into the ground and interconnected by a bent cap at the top of the piles (fig. 18) that provides support for the bridge deck. The three types of piles observed in this study were round timber, steel $\mathrm{H}$, and square concrete (figs. 19, 20, and 21, respectively). The widths for these piles varied from 0.8 to $1.7 \mathrm{ft}$.

Another type of bridge foundation was a pier supported on spread footings or pile groups (figs. 22 and 23) that existed at about 30 percent of the bridges in this study (fig. 15). The piers were generally larger than piles and ranged in width from 1.8 to $6.1 \mathrm{ft}$. On bridges that had been widened to accommodate additional traffic lanes, it was common to find a combination of piers and piles forming a composite bent to support the bridge. Composite bents typically have piers supporting the original structure with piles added upstream and downstream from the old piers to support the newly added lanes (figs. 24 and 25).

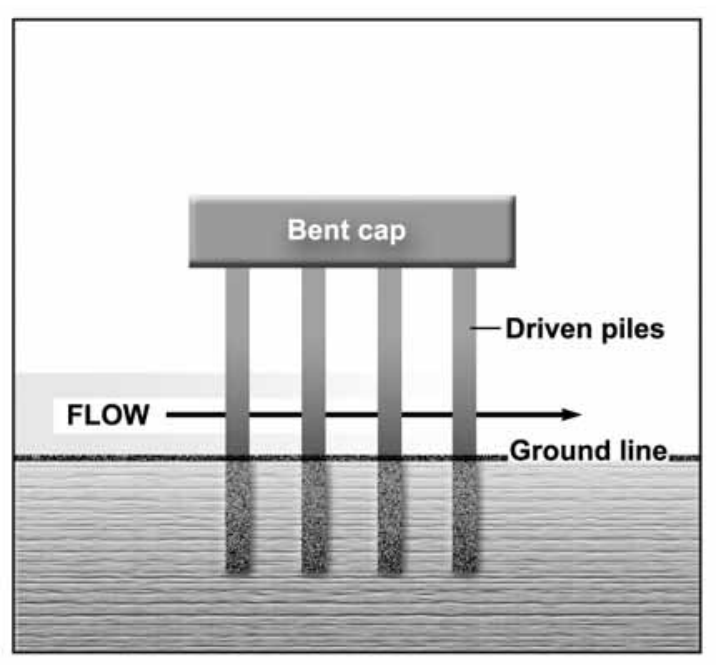

Figure 18. Profile of pile bent.

Although pier scour was not a primary focus for this study, the theoretical pier scour was computed at each bridge to provide some indication of the scour potential of piers when they fall within areas of abutment and contraction scour. HEC-18 (Richardson and Davis, 1995) recommends the following equation for computing theoretical scour at bridges:

$$
\frac{y_{s}}{a}=2.0 K_{1} K_{2} K_{3} K_{4}\left[\frac{y_{1}}{a}\right]^{0.35} F_{1}^{0.43}
$$

where

$y_{\mathrm{s}}$ is the theoretical pier-scour depth, in feet;

$a$ is the pier width, in feet;

$K_{1}$ is the dimensionless correction factor for pier-nose shape;

$K_{2}$ is the dimensionless correction factor for angle of attack;

$K_{3}$ is the dimensionless correction factor for bed conditions;

$K_{4}$ is the dimensionless correction factor for bed armoring;

$y_{1}$ is the approach flow depth, in feet; and

$F r_{1}$ is the approach flow Froude number defined as

$$
F r_{1}=V_{1} /\left(g y_{1}\right)^{0.5}
$$

where

$V_{1}$ is the mean approach velocity, in feet per second; and

$g$ is the acceleration of gravity, in feet per squared second. 


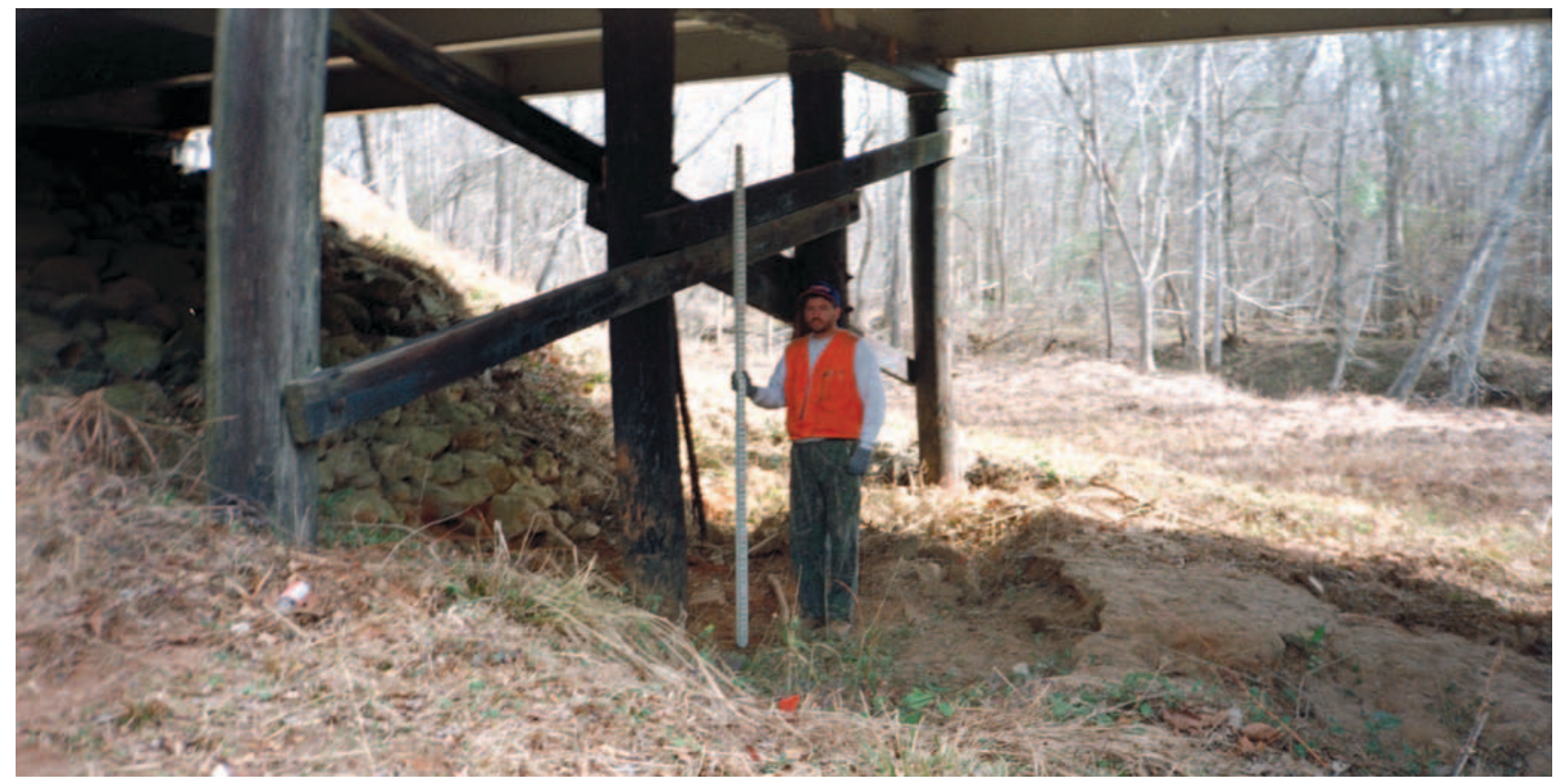

Figure 19. Timber pile bent at Structure 194023000500 on S.C. Route 230, crossing Horne Creek in Edgefield County, South Carolina. (Photograph by the South Carolina District, U.S. Geological Survey, February 6, 1997.)

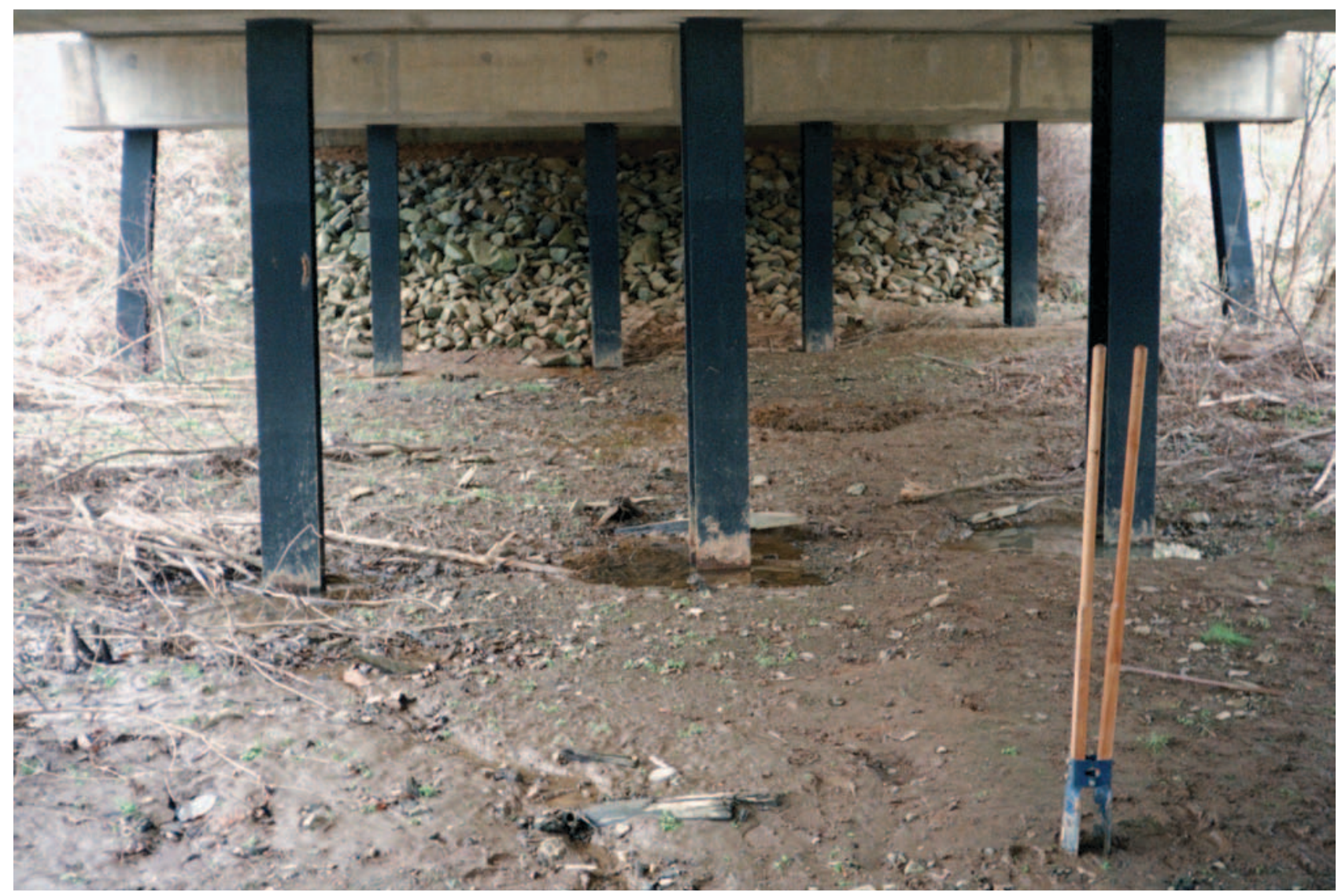

Figure 20. Steel H-pile bent at Structure 467072100100 on Road S-721, crossing Taylors Creek in York County, South Carolina. (Photograph by the South Carolina District, U.S. Geological Survey, January 29, 1997.) 


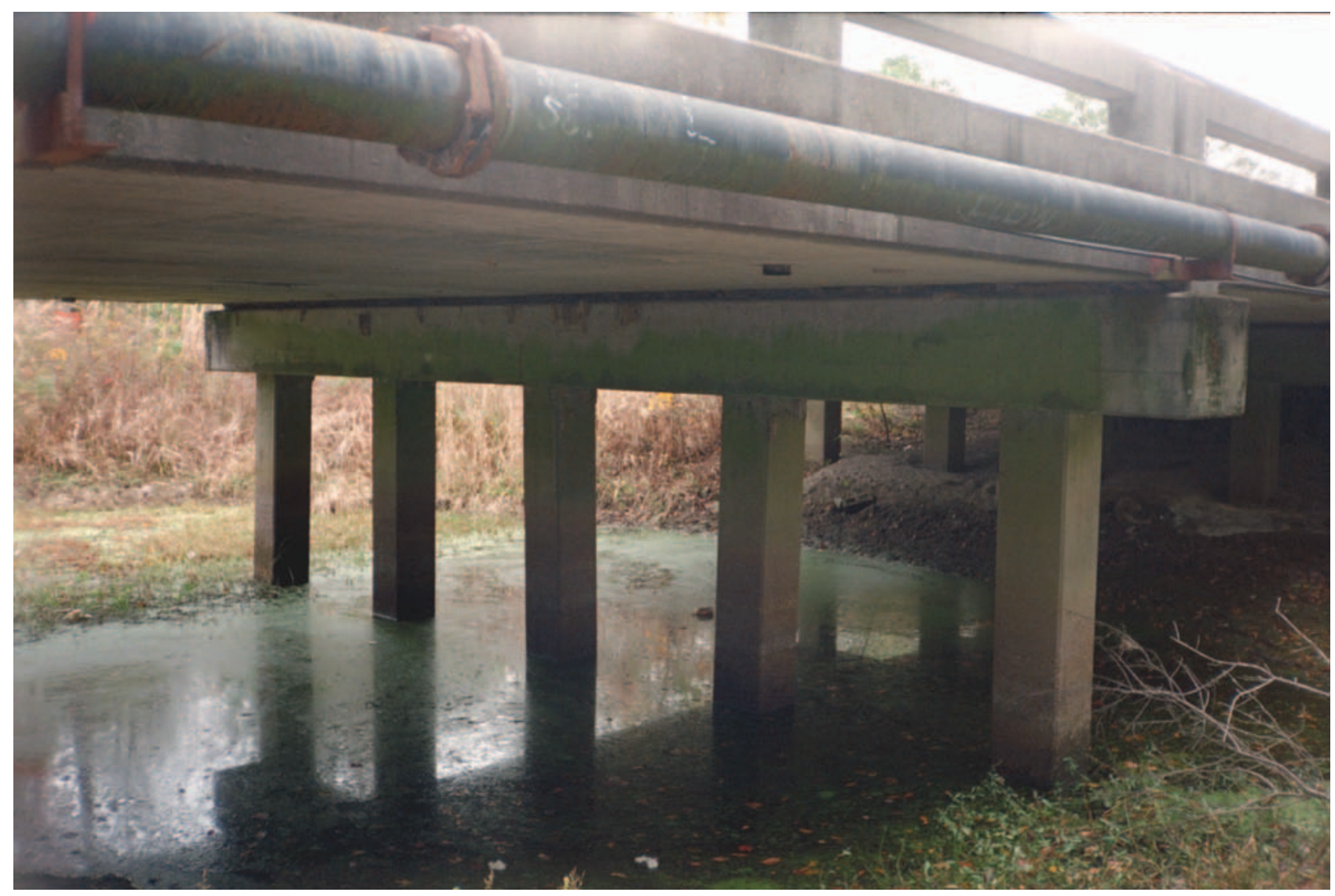

Figure 21. Concrete pile bent at Structure 182007800200 on U.S. Route 78, crossing Polk Swamp in Dorchester County, South Carolina. (Photograph by the South Carolina District, U.S. Geological Survey, November 26,1996.)

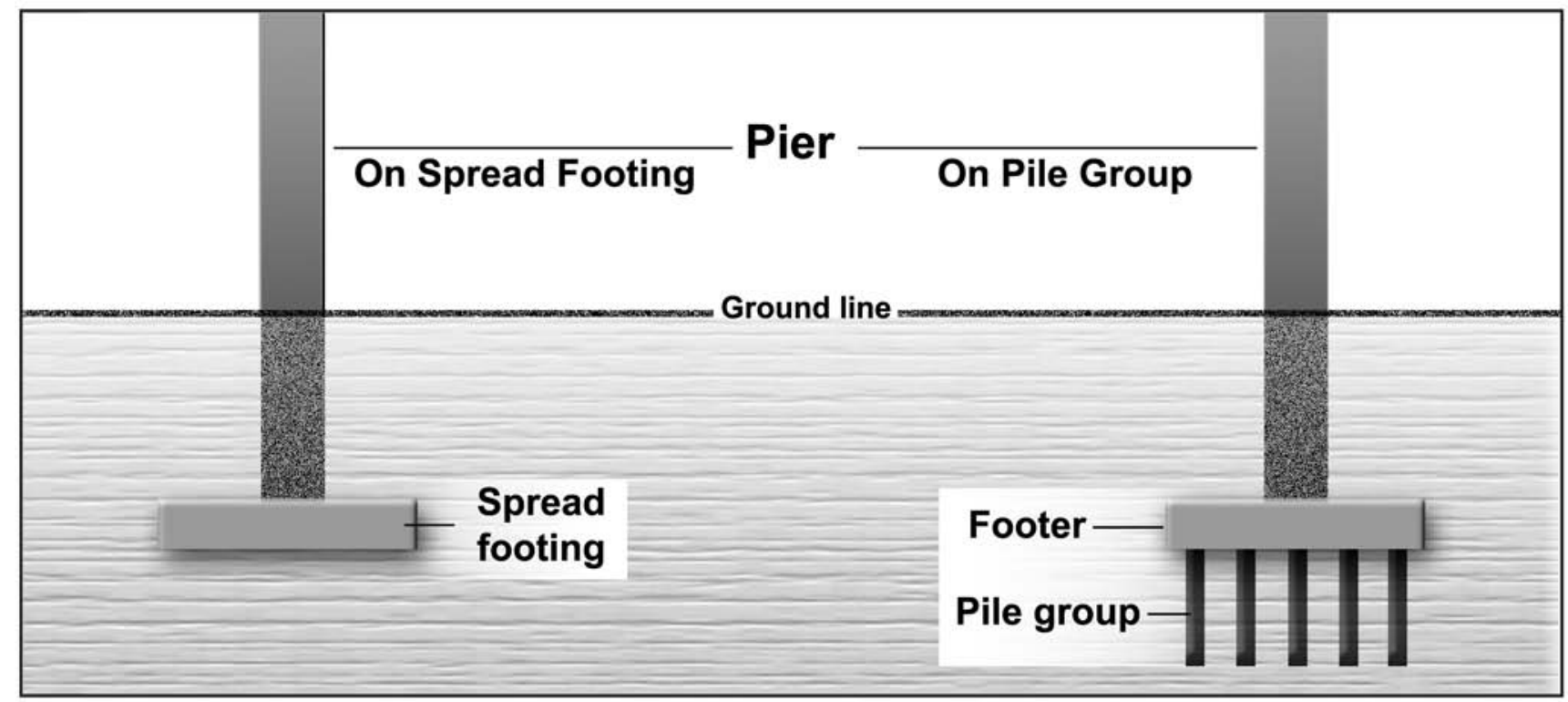

Figure 22. Profile of pier on spread footing and pile group. 


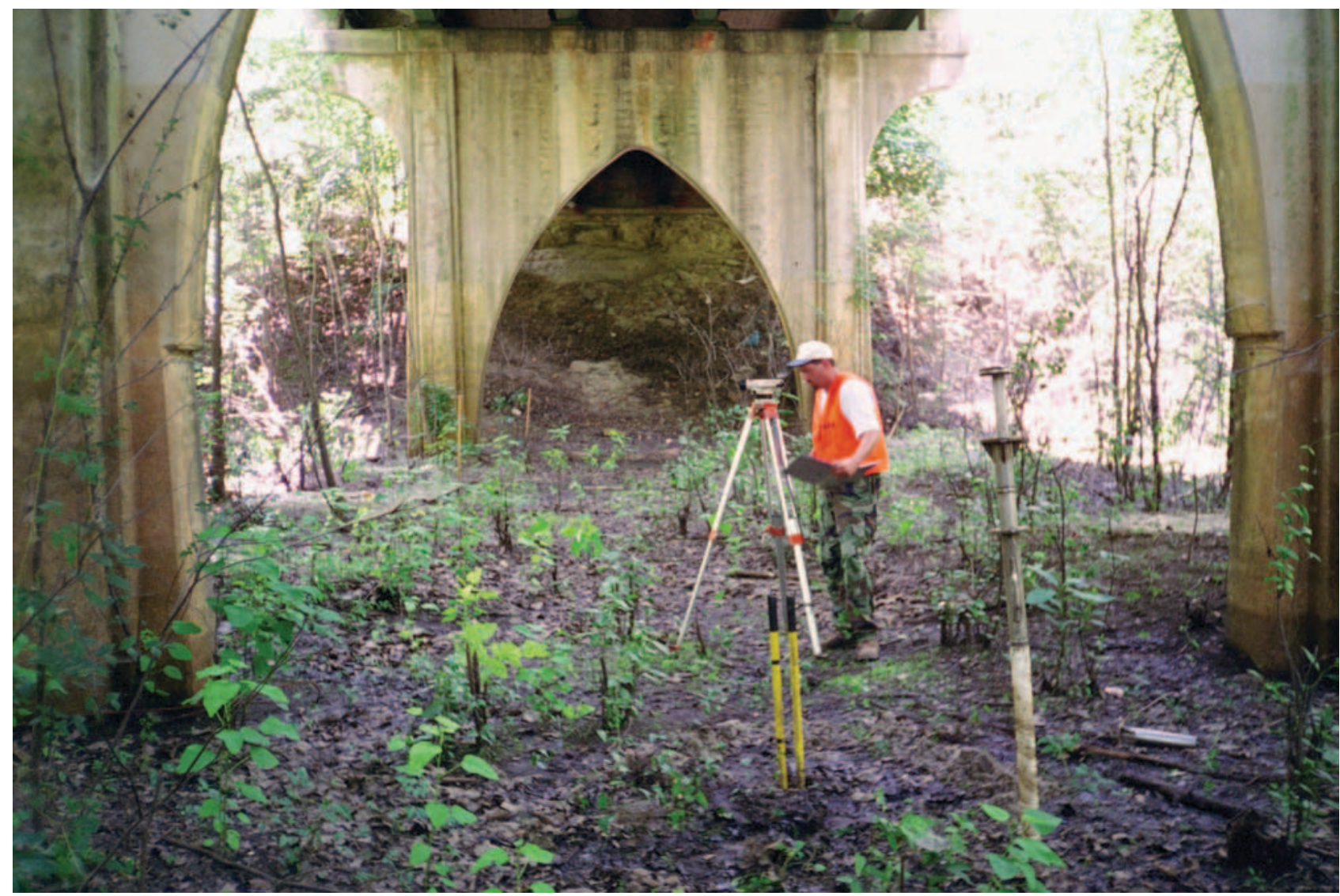

Figure 23. Pier at Structure 262050103100 on U.S. Route 501, crossing the Waccamaw River in Horry County, South Carolina. (Photograph by the South Carolina District, U.S. Geological Survey, June 13, 2000.)

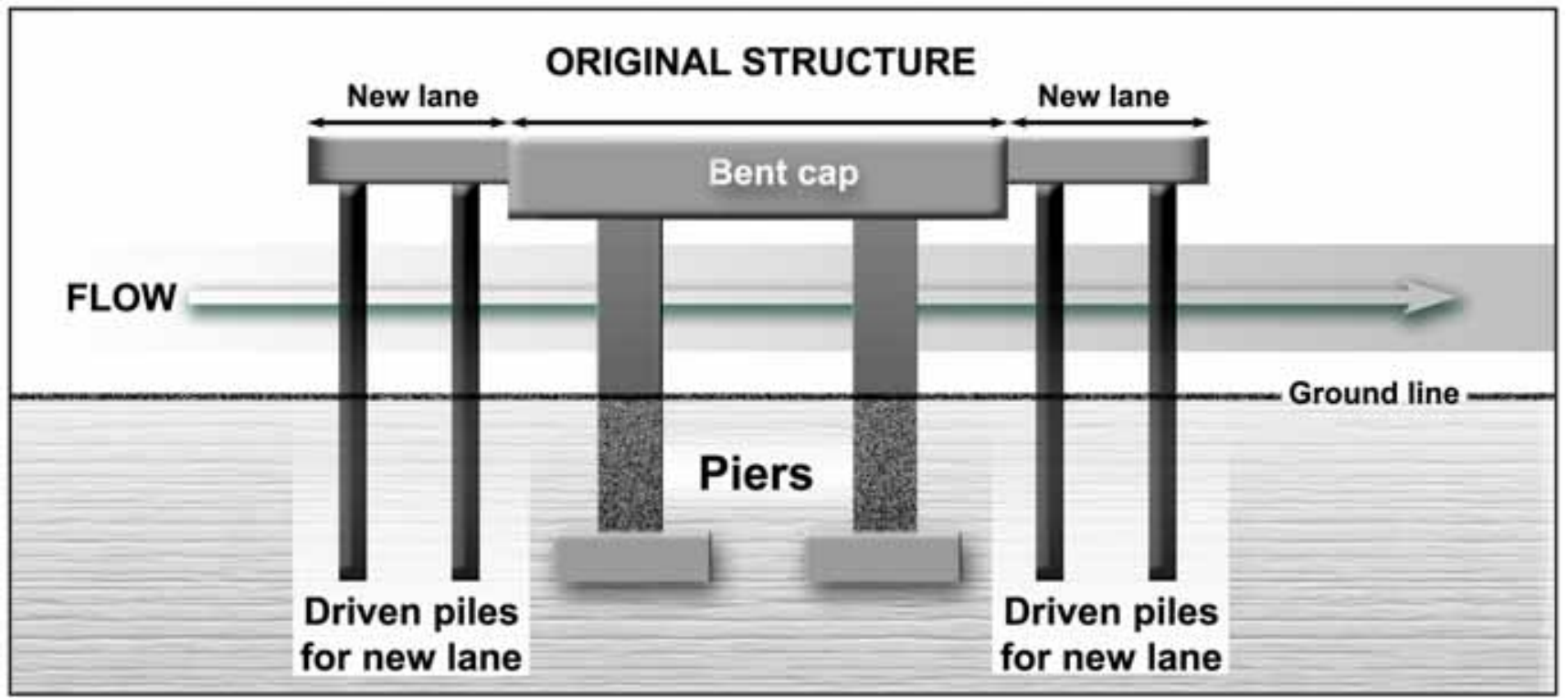

Figure 24. Profile of composite bent. 


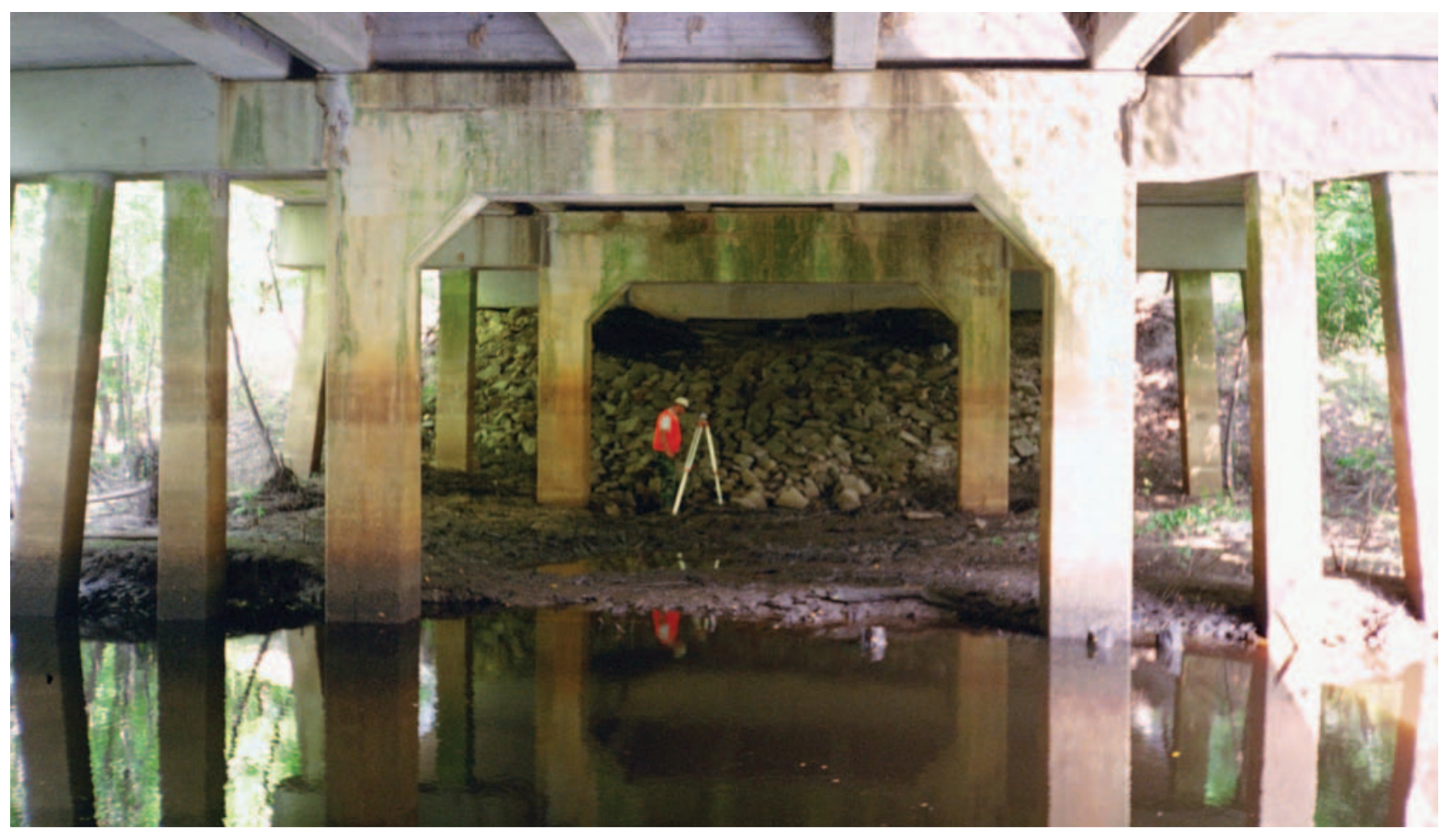

Figure 25. Composite bent at Structure 262050103200 on U.S. Route 501, crossing the Waccamaw River in Horry County, South Carolina. (Photograph by the South Carolina District, U.S. Geological Survey, June 13, 2000.)

When applying this equation to compute local scour around piers and pile bents, the following assumptions and methods were used. In general, the width of the pier or pile was determined by using the pier or pile dimension parallel with the bridge face opening and perpendicular to the direction of flow. For composite bents with columns of varying widths (figs. 24 and 25), the widest column within each bent was used to represent the pier width in the HEC-18 equation. Most bridges in this study had piers or piles that were constant in width along the vertical axis. However, several bridges had piers where width diminished as elevation increased. In such cases, the pier width at the ground line was used in the HEC-18 equation. Although the pier or pile bent length is not used directly in the HEC-18 equation, it is required to determine the correction factor for angle of attack. For pile and composite bents, the pier length was determined by summing the length of each pile or pier parallel with the direction of flow. For solid piers, the pier dimension parallel with the flow was used to represent the pier length.
The correction factor for pier-nose shape, $\mathrm{K}_{1}$, was obtained from HEC-18 (Richardson and Davis, 1995). Pile bents with square piles were assumed to have the shape of a square-nosed pier, whereas pile bents with circular piles were treated as a group of cylinders. The correction factor for angle of attack, $\mathrm{K}_{2}$, also was obtained from HEC-18. To determine this factor, there must be an estimate of the high-flow angle of attack. This angle is typically based on visualizing the flow patterns during high-flow conditions and, as such, has a measure of subjectivity. Field observations and USGS topographic maps were used to estimate the high-flow angle of attack with weight typically given to the topographic map. In general, a single angle of attack was determined for each bridge crossing and applied to all piers at that bridge. For Coastal Plain swamps, backwater upstream from the bridge commonly causes flood flows to pass relatively straight through the bridge opening irrespective of the bridge orientation to the floodplain. In such cases, the angle of attack was considered to be zero. 
Because this study primarily focused on the occurrence of clear-water scour, the bed conditions at piers and pile bents were generally assumed to be clear water. In the case where pier scour was computed in the main channel (live-bed conditions) the plane-bed form was assumed to exist. For both cases, the correction factor for bed conditions, $\mathrm{K}_{3}$ is 1.1 and this was the assigned value for all pier-scour computations. The minimum median grain size $\left(D_{50}\right)$ required for applying the armoring correction factor, $\mathrm{K}_{4}$, is $60 \mathrm{~mm}$. The largest $\mathrm{D}_{50}$ for all bridge sites in the study was 0.99 $\mathrm{mm}$. Therefore, the effects of bed armoring on pier scour were considered negligible, and the correction coefficient, $\mathrm{K}_{4}$, was set to 1.0 for all computations of pier scour.

To calculate the Froude number at a given pier, the stream-tube algorithm within the WSPRO (Shearman, 1990) model was applied to the bridge cross section to obtain estimates of the flow velocity and depth. This algorithm divides the bridge cross section into 20 stream tubes of equal conveyance and computes the flow area and the average velocity within each tube. The stream tube that corresponds with the location of a given pier or pile bent was selected, and the velocity and depth associated with that tube were used to compute the Froude number for the pier or pile bent of interest.

When computing theoretical scour at piers with footings, HEC-18 (Richardson and Davis, 1995) recommends adjusting the bed elevation at a pier to account for the theoretical contraction scour. If a footing is exposed, based on this adjusted bed elevation, then special considerations must be made for computing scour at this pier. In general, field observations showed that piers in this study rarely had exposed footings due to construction constraints or contraction scour. Based on this observation, the special considerations for exposed footings were assumed unnecessary when computing theoretical pier scour.

Because pier scour was not a primary focus of this study, only limited theoretical data were stored in the pier-scour database. At a site with a well-defined low-flow channel, the cross section at the bridge was divided into three subsections defined as the left overbank, right overbank, and main channel (fig. 26). The piers or pile bents within a given subsection were typically identical in geometry and had similar theoretical scour depths. For a given subsection, the pier with the largest theoretical pier-scour depth was selected to represent pier scour for that subsection. The theoretical pier-scour depth and the hydraulic variables used to compute the scour were stored in the theoretical pierscour database. The selected pier-scour depth was identified with the flow of interest (100-year flow, index flow, or maximum historic flow) and the subsection location. The left overbank subsection was identified as 'lfp' for left floodplain. The right overbank subsection was identified as 'rfp' for right floodplain. The mainchannel subsection was identified as 'mcl,' 'mcm,' or 'mcr' for main-channel left, main-channel middle, or main-channel right, respectively (figs. 26 and 27). Piers or pile bents located on the overbanks near the main channel were generally excluded from selection as representative overbank piers. The theoretical scour at these piers was typically influenced by the high velocities within the main channel and did not represent theoretical scour associated with just overbank flows. At swampy sites where a low-flow channel was not well defined, the entire bridge cross section was defined as the main channel and only one pier or pile bent was chosen to represent theoretical pier scour at that bridge (fig. 27). For further details on the variables stored within the theoretical pier-scour database, see appendix A.

\section{Theoretical Live-Bed Contraction Scour}

As with pier scour, live-bed contraction scour was not a primary focus of this study, but was computed, where applicable, to provide some indication of the theoretical contraction scour in live-bed channels. Live-bed contraction scour occurs when bed sediments upstream from a contraction are transported into the contraction scour hole. The low-flow velocities and thick vegetation on the floodplains of most South Carolina streams, limit the transport of bed materials, creating clear water rather than live-bed scour conditions on the floodplain. In contrast, sediments in welldefined low flow channels are available for transport and may experience live-bed contraction scour within the limits of the defined channel. Theoretical live-bed contraction scour was computed at sites containing this live-bed feature, which excluded most Coastal Plain sites and included all Piedmont sites. For computing live-bed contraction scour, HEC-18 (Richardson and Davis, 1995) recommends the use of a modified version of the 1960 Laursen equation for live-bed scour at long contractions, which is defined as: 


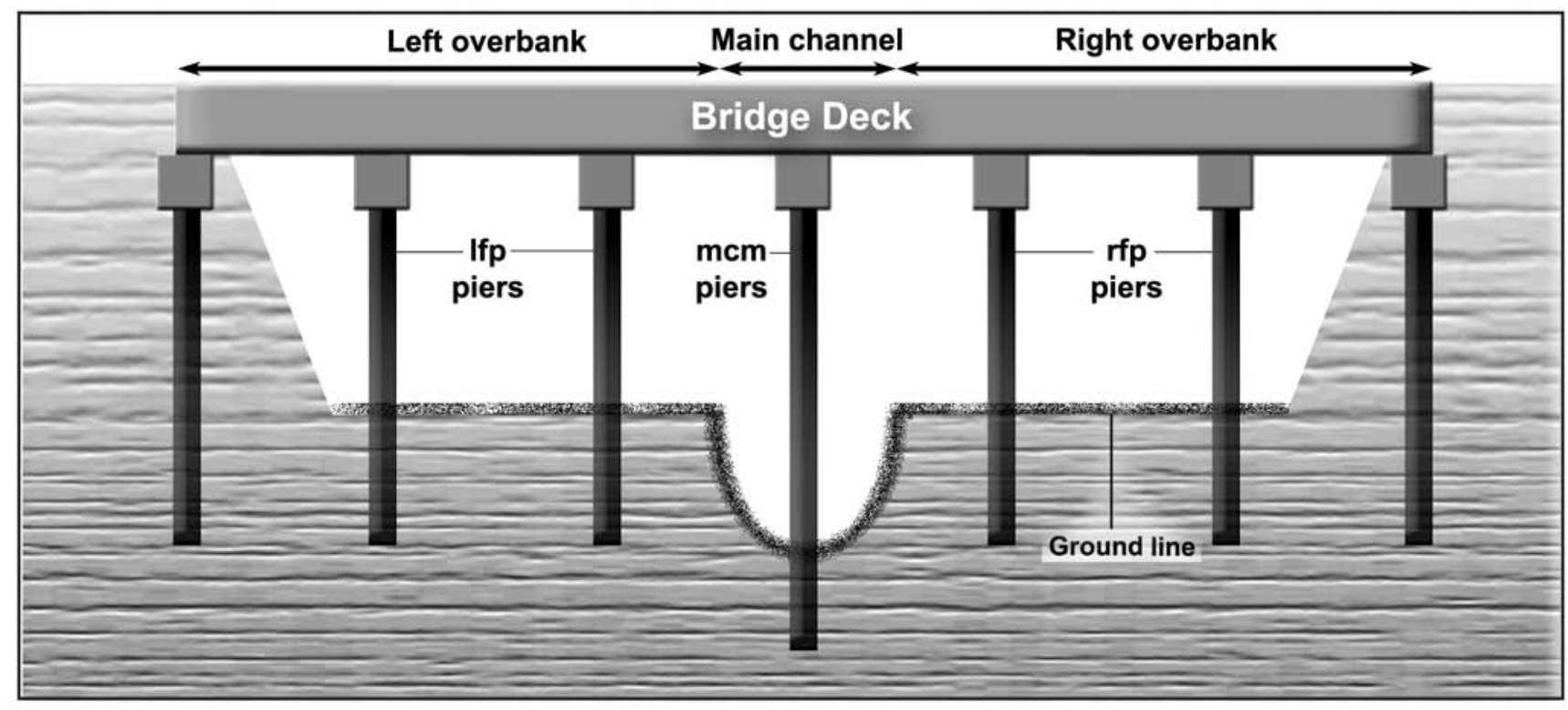

Figure 26. Bridge profile with well-defined low-flow channel, showing subsections and pier identifications for theoretical pier-scour database. [lfp, left flood plain; mcm, main-channel middle; rfp, right flood plain]

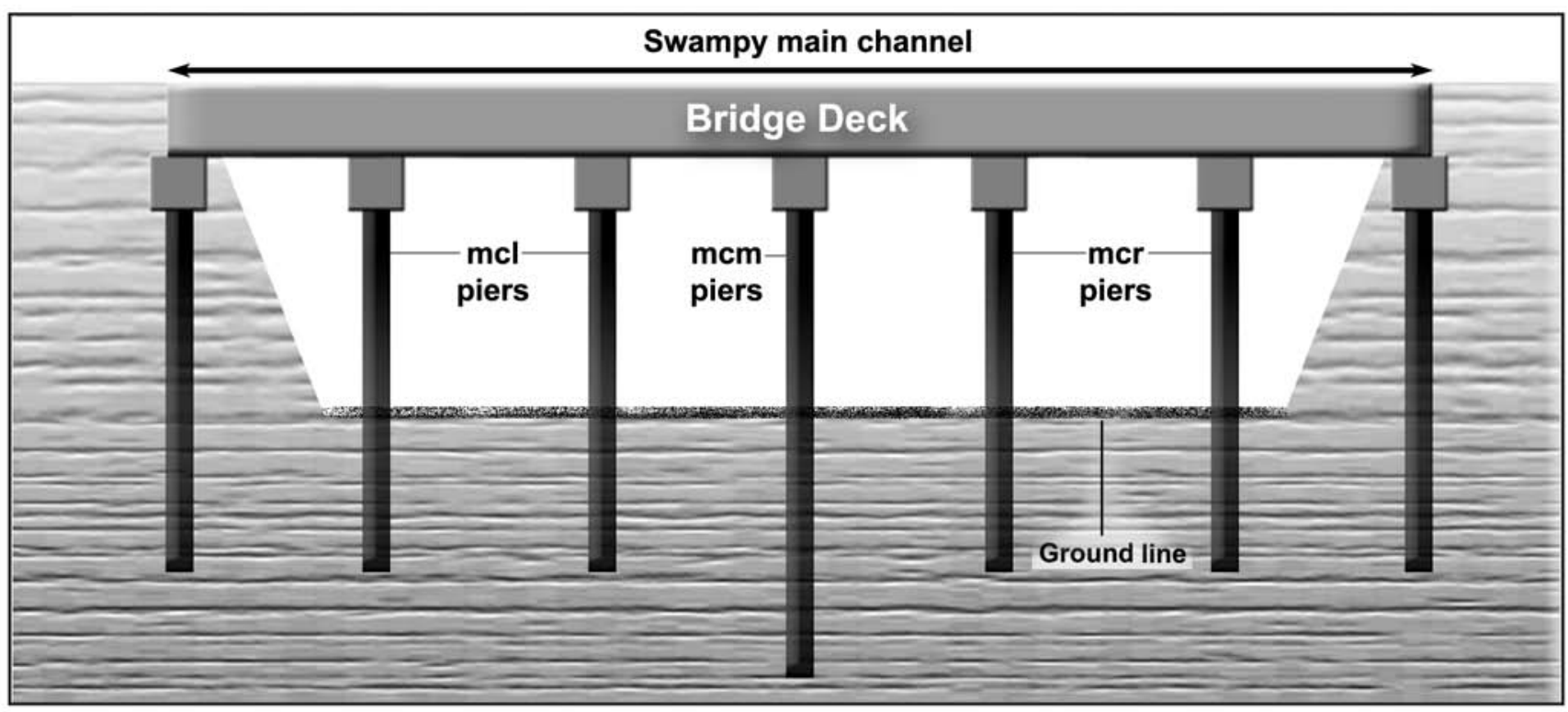

Figure 27. Bridge with swampy channel, showing subsection and pier identifications for theoretical pier-scour database. [mcl, main-channel left; mcm, main-channel middle; mcr, main-channel right] 


$$
\begin{gathered}
\frac{y_{2}}{y_{1}}=\left[\frac{Q_{2}}{Q_{1}}\right]^{\frac{6}{7}}\left[\frac{W_{1}}{W_{2}}\right]^{k_{1}}, \text { and } \\
y_{s}=y_{2}-y_{1},
\end{gathered}
$$

where

$y_{2}$ is the average flow depth in the main channel at the contracted section, in feet;

$y_{1}$ is the average flow depth in the upstream main channel, in feet;

$Q_{1}$ is the flow in the upstream main channel transporting sediment, in cubic feet per second;

$Q_{2}$ is the flow in the main channel at the contracted section, in cubic feet per second;

$W_{1}$ is the bottom width of the upstream main channel, in feet;

$W_{2}$ is the bottom width of the main channel at the contracted section adjusted by subtracting the pier width(s) within the channel, in feet;

$k_{1}$ is an exponent determined from $\mathrm{V}_{*}, \omega$, and the tables in HEC-18;

$y_{S}$ is the average scour depth, in feet;

$\omega$ is the fall velocity of the median bed material $D_{50}$, in feet per second; and

$V_{*}$ is the shear velocity in the upstream main channel, in feet per second, which is defined as $V_{*}=\left(g y_{1} S_{1}\right)^{1 / 2}$,

where

$g$ is the acceleration of gravity, in feet per squared second for $\mathrm{g}$; and

$S_{1}$ is the energy grade line of the main channel, in feet per foot.

The live-bed contraction-scour equation defines $\mathrm{W}_{1}$ and $\mathrm{W}_{2}$ as the bottom widths at the upstream and contracted channel, respectively. In natural channels, the bottom width is often difficult to define. In such cases, HEC-18 (Richardson and Davis, 1995) recommends the use of the channel top widths for defining $\mathrm{W}_{1}$ and $\mathrm{W}_{2}$. This convention was used in all computations of live-bed contraction scour, and the channel top widths were determined as the distance between the channel banks. The flows in the upstream and contracted channels were defined as the flow bounded by the channel banks. This flow was determined by prorating the total flow by the ratio of conveyance within the channel to that of the entire cross section. The average flow depth in the upstream channel was determined by dividing the channel flow area by the channel top width. The energy grade line of the upstream channel was determined from the WSPRO (Shearman, 1990) model. The $\mathrm{D}_{50}$ was determined from a grain-size analysis of a sediment grab sample obtained from the main channel. The fall velocity for the $\mathrm{D}_{50}$ was determined from an algorithm developed by the USGS (Richard J. Huizinga, U.S. Geological Survey, written commun., 1997). The algorithm uses a best-fit equation of the fall-velocity curve presented in HEC-18 (Richardson and Davis, 1995).

Theoretical scour depths and the variables used to compute those depths were stored in the theoretical live-bed contraction-scour database and associated with the flow of interest (100-year flow, index flow, or maximum historic flow). For further details on the stored variables, see appendix A.

\section{Theoretical Clear-Water Contraction Scour}

Clear-water contraction scour occurs where upstream bed sediments are not transported through a contracted section. This condition may occur when velocities upstream from a contraction are insufficient to transport bed materials from the upstream reach into the contraction. Clear-water scour conditions may further be enhanced by dense vegetation that limits sediment transport, regardless of upstream flow velocities. Both conditions typically prevail on the floodplains and swamps of South Carolina making them good candidates for clear-water scour. On streams with well-defined channels, low velocities and dense vegetation on the floodplain create clear-water scour conditions on the bridge overbanks (fig. 28). Likewise, low velocities and thick vegetation in Coastal Plain swamps produce clear-water scour conditions across the entire bridge opening (fig. 29). These types of clear-water contraction scour were the primary focus of this study.

For computing theoretical clear-water contraction scour, HEC-18 (Richardson and Davis, 1995) recommends the use of the Laursen's 1963 equation for clearwater scour at long contractions, and is defined as:

$$
\begin{gathered}
y_{2}=\left[\frac{Q^{2}}{120 D_{m}^{\frac{2}{3}} W^{2}}\right]^{\frac{3}{7}} \text {, and } \\
y_{s}=y_{2}-y_{1},
\end{gathered}
$$




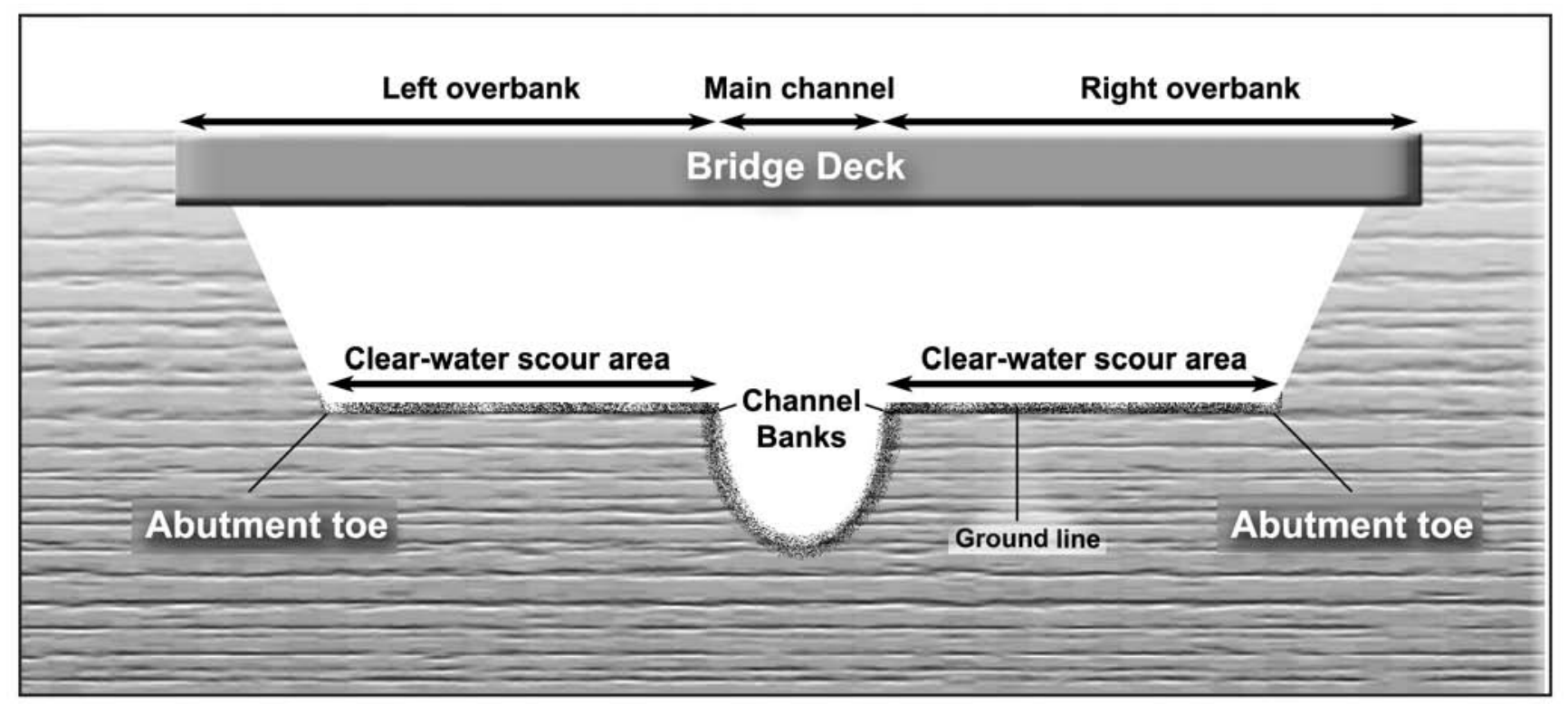

Figure 28. Typical bridge with well-defined low-flow channel, showing areas of clear-water scour.

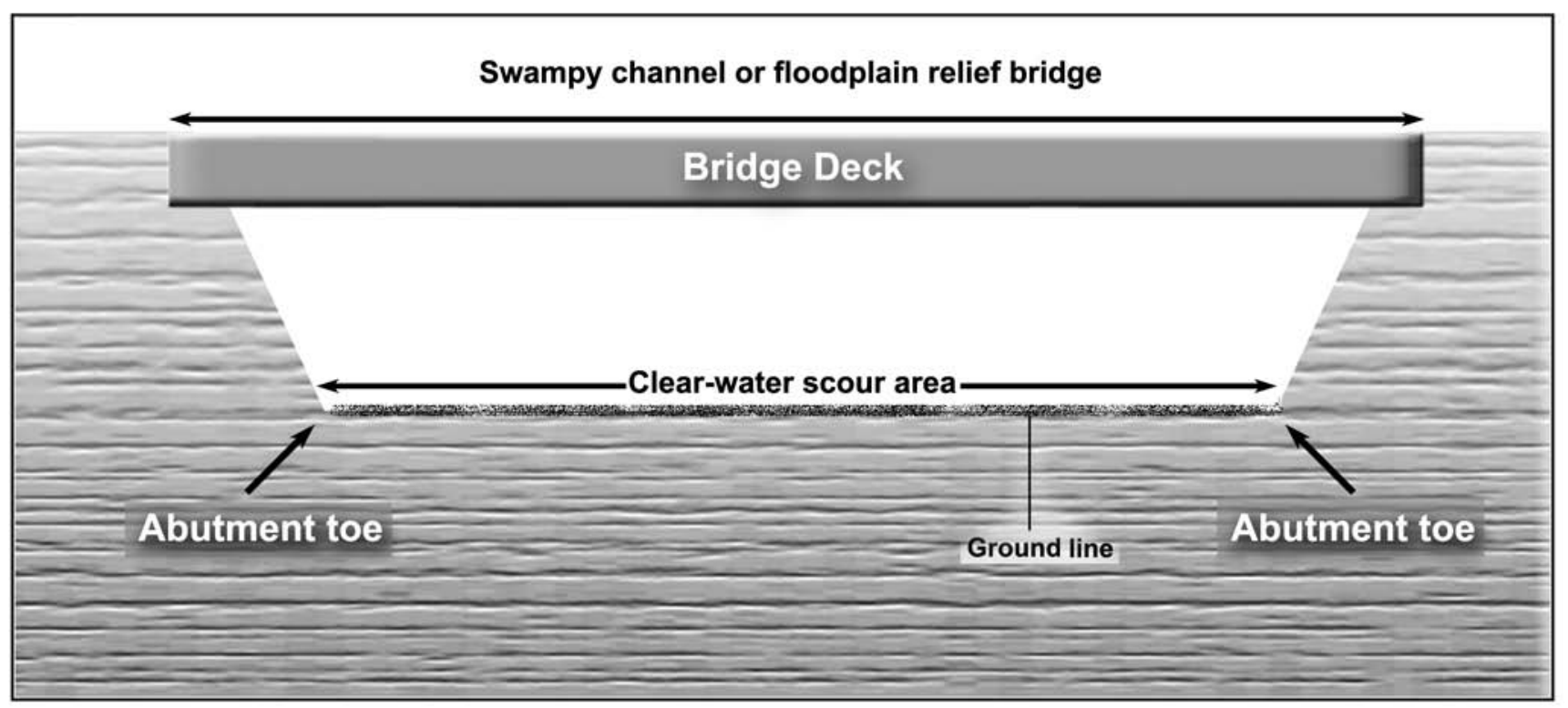

Figure 29. Typical bridge cross section for a swampy channel or floodplain relief bridge, showing area of clear-water scour. 
where

$y_{2}$ is the average depth of flow in the contracted section after the occurrence of contraction scour, in feet;

$Q$ is the flow associated with the contraction width $\mathrm{W}$, in cubic feet per second;

$D_{m}$ is the diameter of the smallest nontransportable particle in the bed material at the contracted section, in feet, and is defined as $D_{m}=1.25 \mathrm{D}_{50}$;

$W$ is the width of the contracted section adjusted by subtracting the pier width(s) within the section, in feet;

$y_{S}$ is the average scour depth in the contracted section, in feet;

$y_{1}$ is the average depth of flow in the contracted section prior to contraction scour, in feet; and

$D_{50}$ is the median grain size of the bed material, in feet.

For sites with well-defined low flow channels, the left and right overbanks were the part of the bridge opening experiencing clear-water contraction scour. Theoretical scour was computed at each overbank. The contracted width for a given overbank was defined as the distance from the abutment toe to the channel bank (fig. 28). The flow across the overbank was determined by prorating the total flow through the bridge by the ratio of conveyance within the overbank to that of the entire bridge cross section. The average depth of flow prior to the occurrence of contraction scour was obtained by dividing the flow area at the overbank by the overbank width. For Coastal Plain sites with swampy channels, the entire channel at the bridge opening experiences clear-water contraction scour (fig. 29). In this case, the contracted width was defined as the distance from the abutment toe to abutment toe and procedures defined above were used to determine the other variables. The $\mathrm{D}_{50}$ was determined from a grain-size analysis of a sediment grab sample. To obtain a representation of the pre-scour sediments, the sample was taken upstream from the contraction, outside the limits of any scour.

Theoretical scour depths and the variables used to compute those depths were stored in the theoretical clear-water contraction-scour database and associated with the flow of interest (100-year flow, index flow, or maximum historic flow). For further details on the stored variables, see appendix A.

\section{Theoretical Abutment Scour}

Abutment scour was a primary focus of this study, and therefore, theoretical abutment-scour depths were computed at all bridge sites. The current study had spill-through abutments at 143 bridges with the remaining 3 bridges having vertical abutments. Spill-through abutments have a sloping, earthen embankment under the bridge deck (figs. 30 and 31) and are often protected by riprap. Vertical abutments have vertical concrete walls that function as a retaining wall for the road embankment fill (fig. 32). Hydraulic Engineering Circular Number 18 (Richardson and Davis, 1995) recommends the use of the Froehlich (1989) live-bed abutment-scour equation or the "Highways in the River Environment" (HIRE) (Richardson and others, 1990) equation for predicting theoretical abutment scour. These equations were used in this study and are defined below.

The Froehlich (1989) live-bed abutment-scour equation is defined as:

where

$$
\frac{y_{s}}{y_{a}}=2.27 K_{1} K_{2}\left[\frac{L}{y_{a}}\right]^{0.43} F^{0.61}+1 \text {, }
$$

$y_{S}$ is the abutment-scour depth, in feet;

$y_{a}$ is the average depth of flow on the floodplain upstream from the abutment, in feet;

$K_{1}$ is the dimensionless correction factor for abutment shape determined from table in HEC-18;

$K_{2}$ is the dimensionless correction factor for the angle of embankment to flow;

$L$ is the length of the embankment projected normal to flow, in feet; (Many laboratory investigations define the road embankment that blocks approaching flows as the abutment length. In this report, the term embankment length is used.); and

$\mathrm{Fr}$ is the Froude number of the flow upstream from the embankment, which is defined as:

where $F r=V_{e} /\left(g y_{a}\right)^{0.5}$,

$V_{e}$ is the average flow velocity upstream from the embankment, in feet per second, and is defined as: $V_{e}=Q_{e} / A_{e}$,

where

$Q_{e}$ is the flow obstructed by the embankment, in cubic feet per second; and

$A_{e}$ is the flow area obstructed by the embankment, in square feet; and

$g$ is previously defined. 


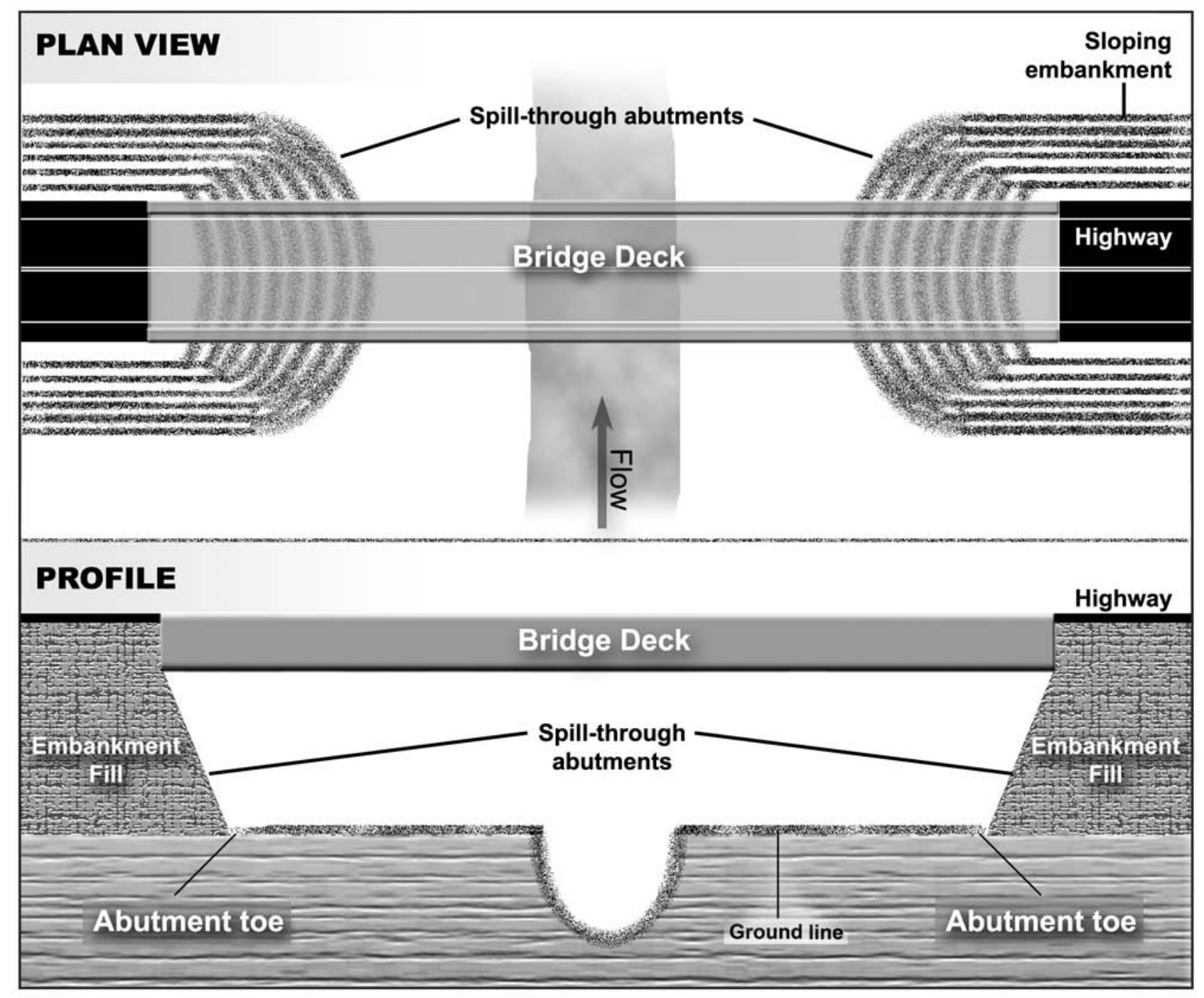

Figure 30. Plan view and profile of spill-through abutment.

The value of 1 at the end of the equation is the safety factor that forces the equation to encompass 98 percent of the laboratory data (Froehlich, 1989).

The HIRE (Richardson and others, 1990) equation defined below is applicable only when the ratio of embankment length and flow depth at the abutment is greater than 25:

$$
\frac{y_{s}}{y_{1}}=4\left[\frac{K_{1}}{0.55}\right] F r^{0.33},
$$

where

$y_{S}$ is the abutment-scour depth, in feet;

$y_{1}$ is the depth of flow upstream and adjacent to the abutment, in feet;

$K_{1}$ is the dimensionless correction factor for abutment shape determined from a table in HEC-18;

$\mathrm{Fr}$ is the Froude number of the flow upstream and adjacent to the abutment, and is defined as: $\operatorname{Fr}=V_{e} /\left(g y_{1}\right)^{0.5}$,

where

$V_{e}$ is the flow velocity upstream and adjacent to the abutment, in feet per second; and

$g$ is previously defined. 


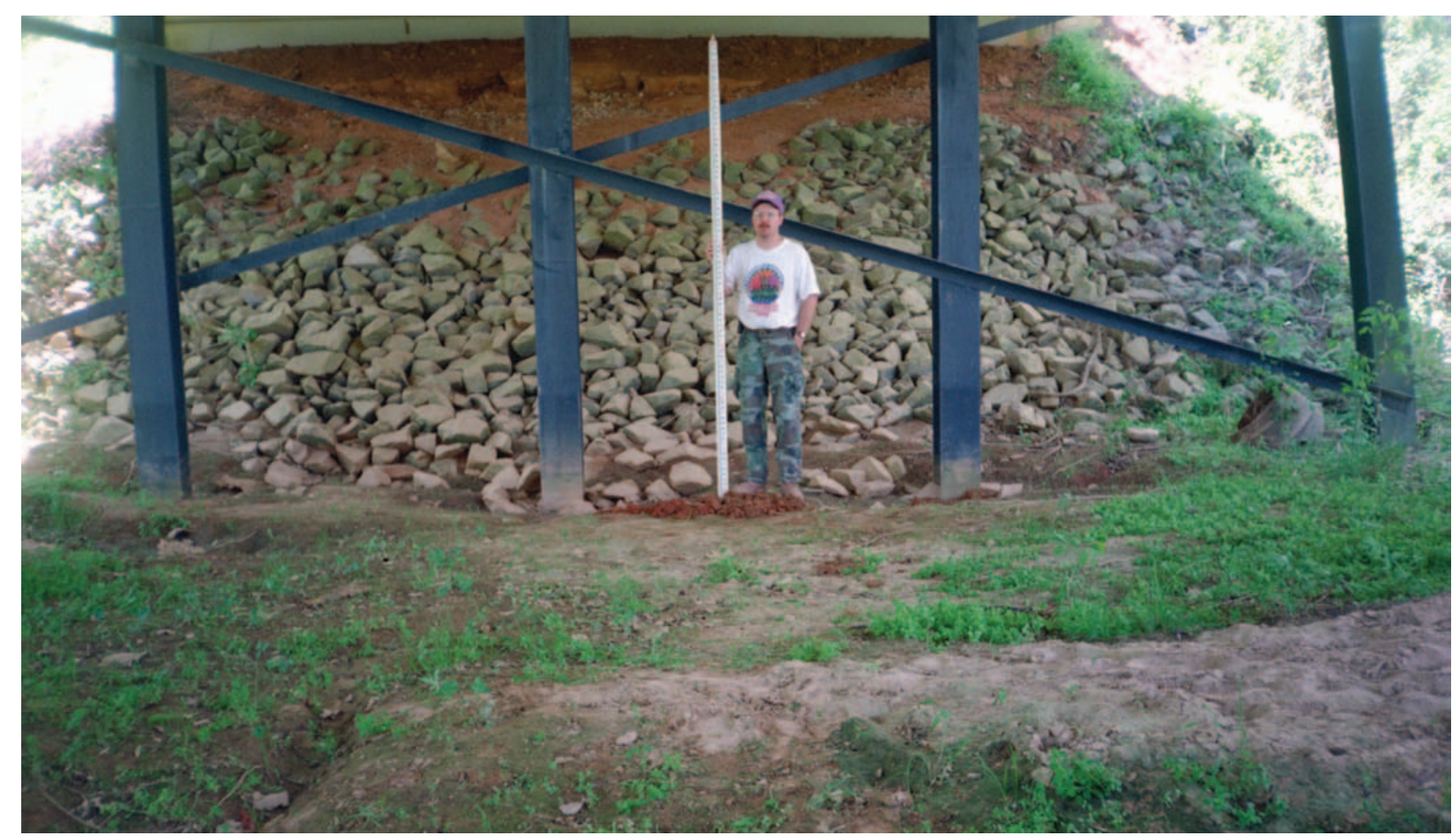

Figure 31. Spill-through abutment at structure 307011200100 on Road S-112, crossing the Enoree River in Laurens County, South Carolina. (Photograph by the South Carolina District, U.S. Geological Survey, April 2,1997.)

The Froehlich (1989) equation was used to compute theoretical scour at all bridges in the study. Although the HIRE (Richardson and others, 1990) equation is limited to sites with embankment length to flow depth ratio greater than 25 , computations were made at all sites regardless of the ratio. The variables used in the Froehlich (1989) equation were determined in the following manner. The length of the embankment was determined by projecting the bridge cross section onto the approach cross section and using the distance from edge of water to the projected abutment toe as the embankment length (fig. 33).

The obstructed flow area was determined by using the approach cross-section geometry and watersurface elevation to calculate the flow area across the embankment length (fig. 33). The obstructed flow was determined by prorating the total flow by the ratio of conveyance across the embankment length to that of the entire approach cross section. The average flow depth on the approach floodplain was determined by dividing the obstructed area by the embankment length. Abutment-scour computations with the Froehlich (1989) equation were made with and without the safety factor.

For the HIRE (Richardson and others, 1990) equation, the velocity adjacent to the abutment was determined by using the WSPRO stream-tube algorithm at the bridge cross section. The average velocity in the tube at the abutment was chosen to represent $\mathrm{V}_{e}$. The depth of flow at the abutment was determined by subtracting the ground elevation at the abutment toe from the water-surface elevation at the bridge.

Theoretical abutment-scour depths and the variables used to compute those depths were stored in the theoretical abutment-scour database and were associated with the flow of interest (100-year flow, index flow, or maximum historic flow). For further details on the stored variables, see appendix A. 


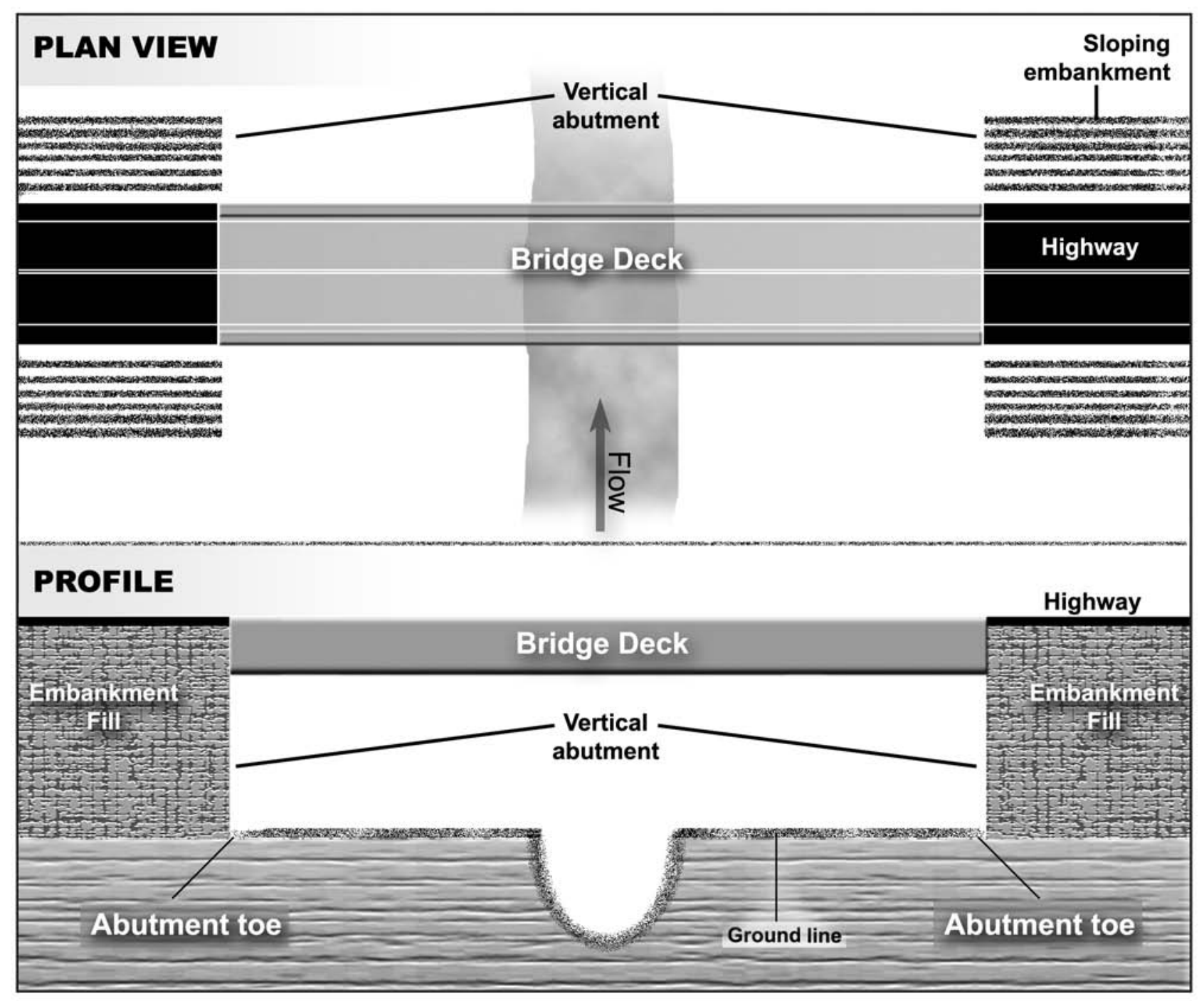

Figure 32. Plan view and profile of vertical abutment.

\section{VARIABLES INFLUENCING ABUTMENT SCOUR}

Local bridge scour is the erosion of bed material from around flow obstructions such as piers and abutments. The mechanism that causes the erosion is the combined effect of flow acceleration and the resulting vortices that are induced by the obstructions (Richardson and Davis, 1995). In the case of a bridge abutment, flood flow is diverted from its natural flow path by a road embankment and contracted into a bridge opening (fig. 34). Under ideal conditions, contraction causes the acceleration of flow along the path of a streamline, and the largest velocity magnitudes exist near the edge of the contracted section (Rouse, 1946). At a bridge, the edge of the contracted section corresponds to the tip of a road embankment and is defined as a bridge abutment. In addition to the accelerated flows near the abutment, the severe flow curvature in this area promotes the development of vortices that have been identified in laboratory studies as the primary mechanism for abutment scour (Dongol, 1993).

The accelerated flows caused by a bridge contraction can be shown schematically by the use of streamlines and stream tubes. A streamline represents the path that a particle of water will follow. A stream tube represents a hypothetical flow tube formed by adjacent streamlines. The volumetric flow within a stream tube is assumed to remain constant. 


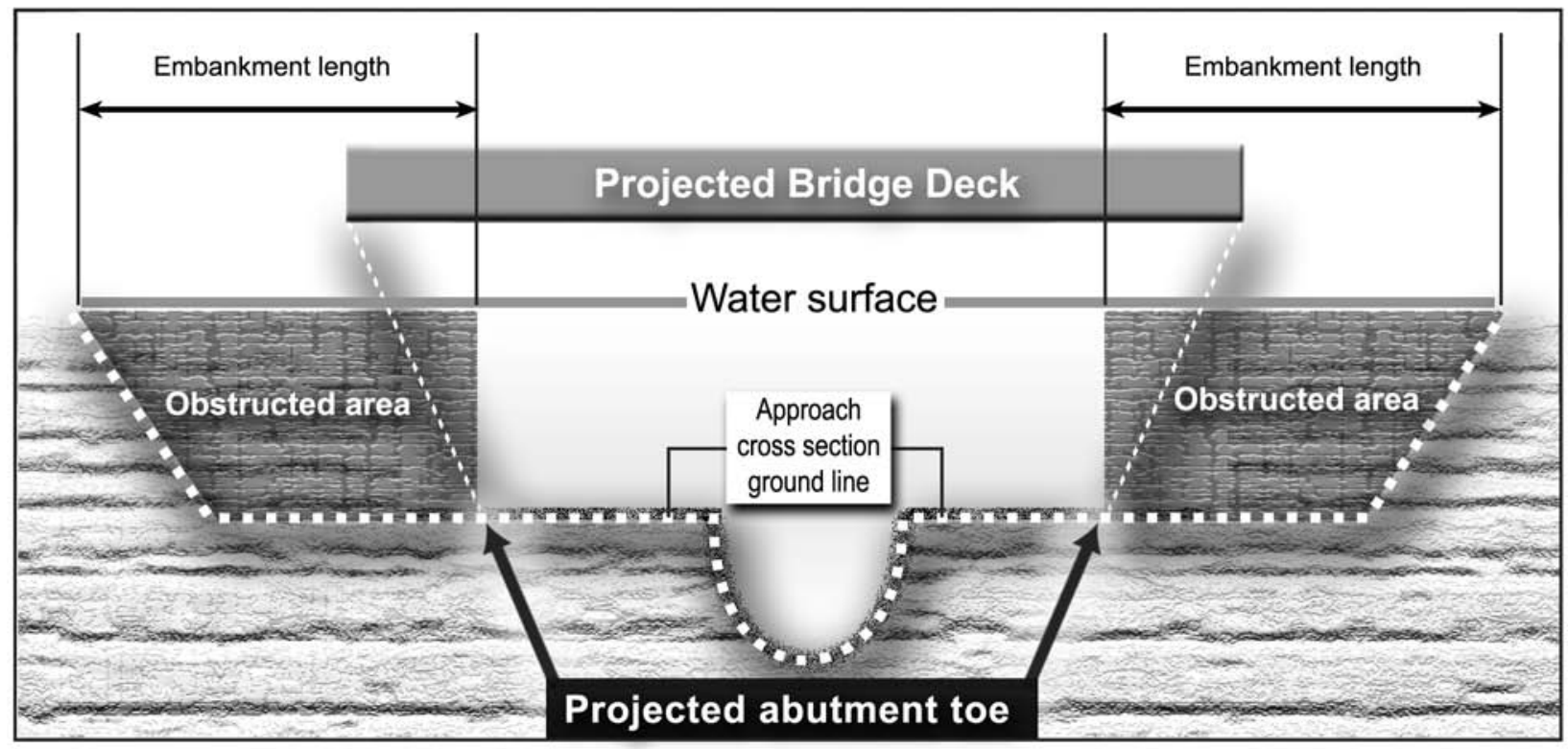

Figure 33. Embankment length and obstructed flow area determined by projection of the bridge cross section onto the approach cross section.

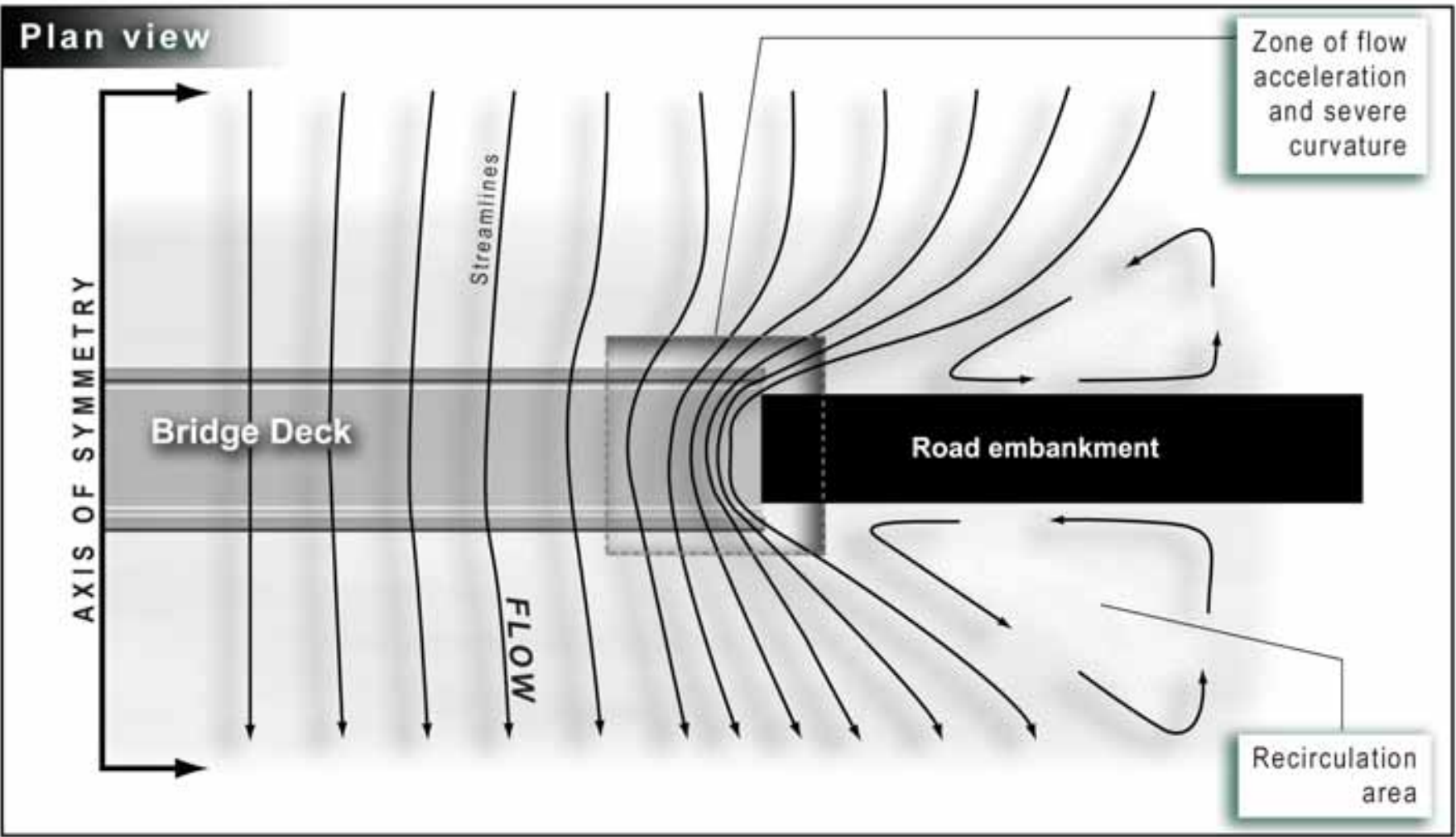

Figure 34. Simplified streamline patterns at a bridge contraction. 
Therefore, as a stream tube is constricted, the flow velocity at the constriction must increase to conserve the constant flow. Figure 34 shows a simplified schematic of steady-flow streamline and stream-tube patterns at a bridge contraction, illustrating the severe stream-tube constriction and curvature of streamlines in the abutment area. The combination of increased velocities and flow curvature, as illustrated by the stream tubes, provides an ideal environment for producing vortices that in turn will promote abutment scour. With lateral distance from the abutment, the stream-tube constriction and streamline curvature significantly diminish, indicating a reduced potential for scour. Field observations indicate that abutment scour in South Carolina commonly occurs where the severe constriction and curvature of the stream tubes would be anticipated. Likewise, where the severity of these flow patterns would be expected to diminish, with distance from the abutment, much smaller depths of scour are typically observed.

Numerous laboratory studies have investigated the variables that influence abutment scour. Dongol (1993), reviewing previous studies of abutment scour, compiled a list of influencing variables and described the effect of each. A detailed discussion of these variables is beyond the scope of this report, and for more details, the reader is referred to Dongol (1993). Dongol classified the variables influencing abutment scour into the seven categories listed below:

(1) Variables describing the channel

- channel width $\quad$ channel slope

- channel geometry

(2) Variables describing the abutment

- embankment length $\quad$ abutment shape

- skew

(3) Variables describing the flow

- flow depth

- energy slope

(4) Variables describing the bed material

- median size - specific gravity

- gradation

- fall velocity

- particle shape factor

- cohesiveness

- angle of repose

- dimensionless critical-shear stress

(5) Variables describing the fluid

- dynamic viscosity $\cdot$ density

(6) Temperature

(7) Time
This list includes 23 variables that have been observed to influence abutment scour in laboratory studies, demonstrating that scour processes can be complex.

To simplify the study of scour processes, laboratory investigations of abutment scour often use noncohesive, granular bed materials of constant specific gravity and water flows of constant temperature. Under these conditions, cohesion, particle shape factor, angle of repose, fall velocity, sediment specific gravity, water density, dynamic viscosity, and temperature can be assumed constant, and the relation of abutment scour to influencing variables can be simplified (Dongol, 1993). Using this simplified relation, along with other simplifying assumptions, Dongol presents a shortened list of the primary influencing variables and describes their effect on abutment scour as observed in various laboratory investigations. This list of influencing variables includes time, flow velocity, flow depth, sediment size, sediment gradation, embankment length, abutment shape, embankment skew, and channel geometry.

The simplifying assumptions presented in Dongol (1993) may not be valid for field conditions. For example, a constant specific gravity of the bed material may be a reasonable assumption; however, to assume a noncohesive bed material is probably unreasonable. Even the sandy soils of the Coastal Plain of South Carolina commonly have some silts, clays, and organic materials mixed with the sands, providing some degree of cohesion. In addition, water temperatures can significantly vary as the seasons change. For example, in water year 1998 (from October 1997-September 1998) the USGS gaging station 02163001 on the Saluda River near Williamston, S.C., recorded a minimum water temperature of $39^{\circ} \mathrm{F}$ on January 3, 1998, and a maximum temperature of $86^{\circ} \mathrm{F}$ on July 1, 1998. A temperature change from 86 to $39^{\circ} \mathrm{F}$ changes the water density by only 0.4 percent. The same temperature change, however, causes a 95-percent increase in the dynamic viscosity (Gerhart and others, 1992). Because fluid shear stresses are directly related to viscosity, an increase of this magnitude could influence the scour process.

Because conditions in the field can be substantially different from the simplified conditions of the laboratory, direct application of laboratory results to the field may not be justified. However, it is reasonable to assume that trends within the laboratory also should be observed in the field and, therefore, laboratory investigations should provide valuable insights for understanding abutment scour under field conditions. With this assumption in mind, a brief description of 
some laboratory findings and how they may relate to abutment scour in South Carolina is presented. Discussion, in general, will be limited to the influencing variables for the simplified abutment-scour relation (Dongol, 1993). In this study, hydraulic variables associated with field observations were estimated using the one-dimensional model, WSPRO (Shearman, 1990). Because most sites do not have historical flow data, the theoretical 100-year flow was used as a common condition to gain insights about the hydraulics that may occur during a large flood. Therefore, when hydraulic variables, such as embankment length, flow velocity, flow depth, and geometric-contraction ratio, are mentioned in this report, they should be viewed as estimated rather than measured data. Because clear-water scour is the focus of the current study, laboratory findings related to clear-water scour is the primary focus in the following review.

\section{Time And Flow Duration}

To reach clear-water equilibrium-scour depths under laboratory conditions, experiments must typically run at constant-flow conditions for several days (Dongol, 1993). Because of scaling effects, events in small laboratory models (such as flumes) in general, should have shorter durations than a similar event under field conditions. Therefore, to reach clear-water equilibrium-scour conditions in the field, peak-flow durations may need to be longer than several days. Because natural hydrographs may peak and recede within hours rather than days, the concept of equilibrium scour, as defined in the laboratory, may not be applicable to the field. In South Carolina, it is unlikely that peak flows for events such as the 100-year flow will be sustained for several days. This can be demonstrated using the regionalized dimensionless hydrographs developed for South Carolina (Bohman, 1990) where regional dimensionless hydrographs were derived from observed data-three dimen- sionless hydrographs for the Coastal Plain and one for the Piedmont.

To provide some perspective on the differing shapes of the hydrographs between the Coastal Plain and Piedmont, a plot of the 100-year hydrograph for two hypothetical 200- $\mathrm{mi}^{2}$ basins are shown in figure 35 . As demonstrated in figure 35, Piedmont hydrographs are much shorter in duration than Coastal Plain hydrographs. Therefore, scour depths in the Coastal Plain will more likely approach equilibrium-scour depths for peak flows than will those in the Piedmont.

Assuming that the hydrograph duration for 95 percent of the 100-year flow (fig. 35) represents the duration of the peak flow, a plot of the relation of the 100-year peak-flow duration and drainage area is shown in figure 36 . This figure demonstrates that South Carolina drainage basins under $2,000 \mathrm{mi}^{2}$ are unlikely to have sustained flow durations of 2 days for flows approaching the 100-year magnitude. Drainage areas for the bridge sites used in this study range from 6 to $8,830 \mathrm{mi}^{2}$ with 94 percent of the drainage areas less than $2,000 \mathrm{mi}^{2}$ (fig. 3). Because of shorter duration flows associated with drainage basins under 2,000 $\mathrm{mi}^{2}$, field measurements of scour depths in this study will likely be less than corresponding equilibrium-scour depths associated with scaled laboratory studies.

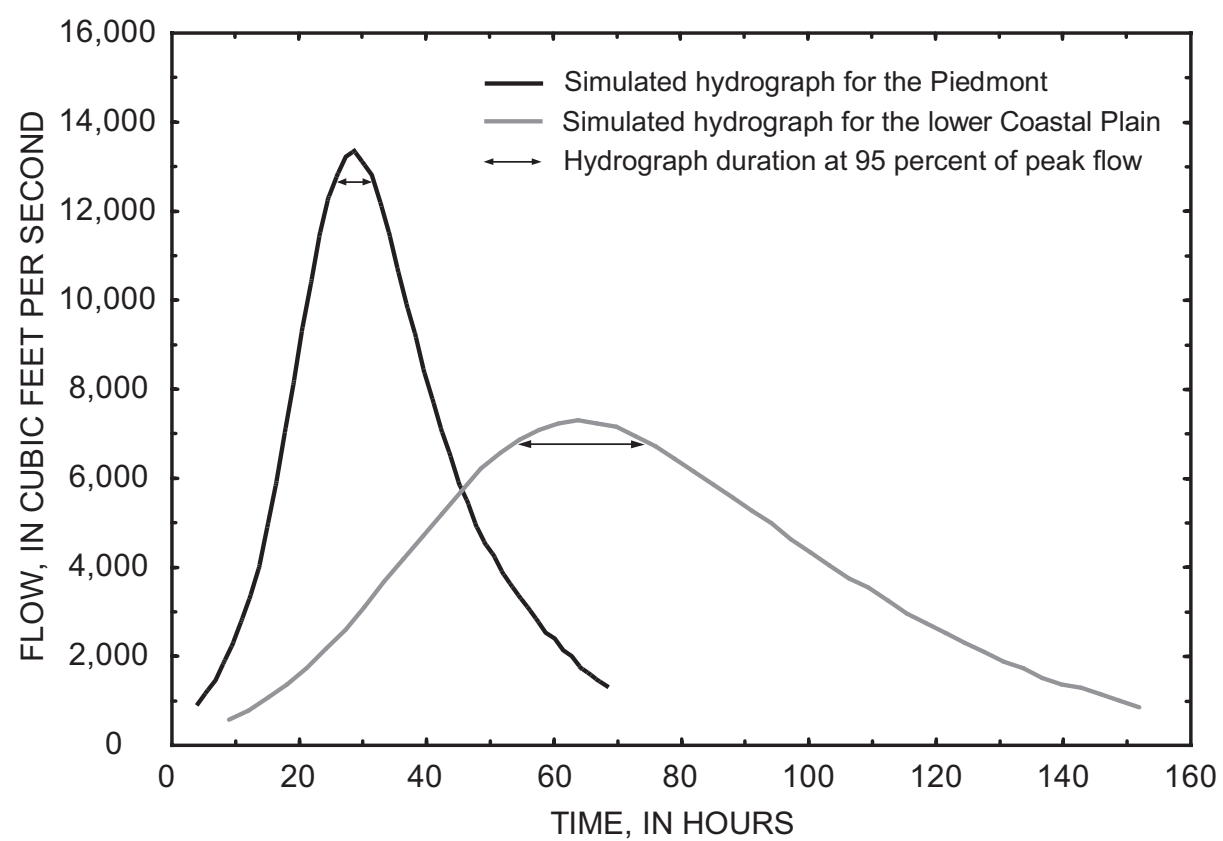

Figure 35. Comparison of the simulated 100-year-flow hydrographs for 200-square mile basins in the Piedmont and lower Coastal Plain of South Carolina. 


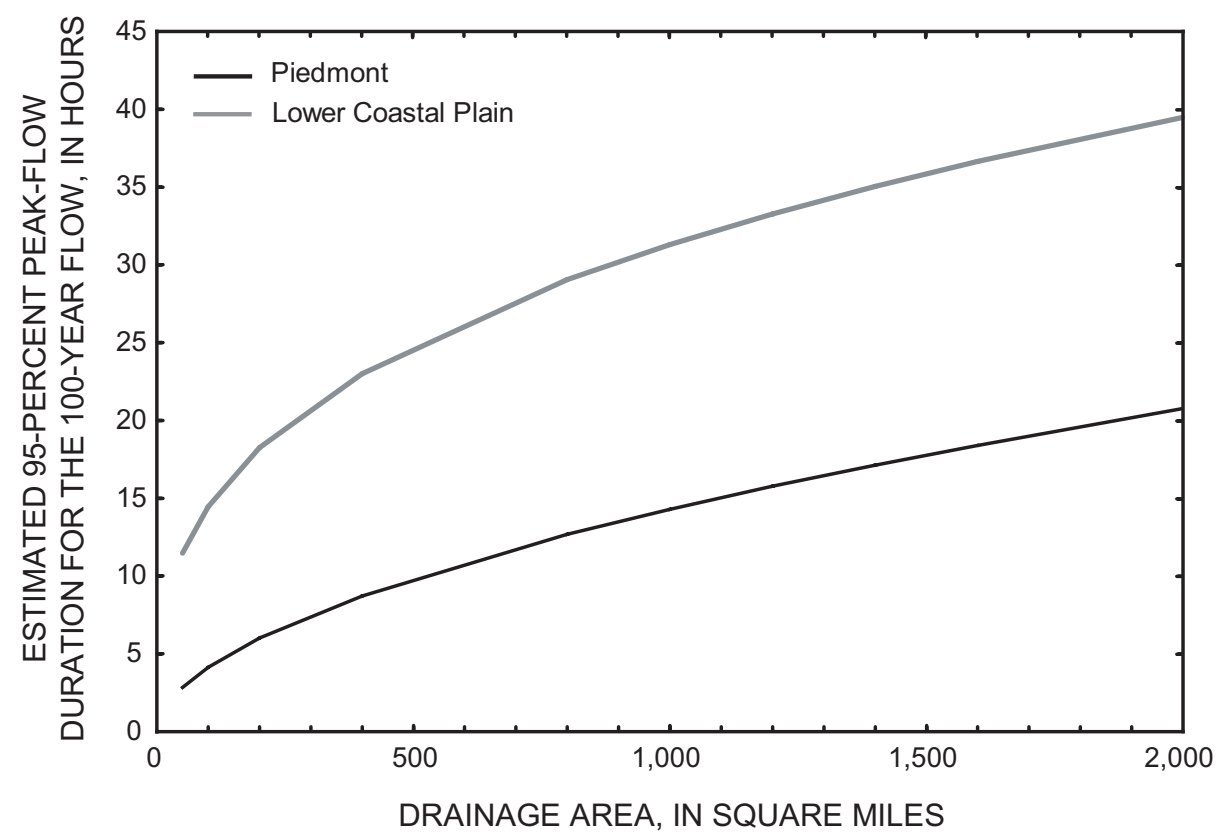

Figure 36. Comparison of hydrograph durations at 95 percent of the peak flow estimated from simulated 100-year-flow hydrographs for various basin sizes in the Piedmont and lower Coastal Plain of South Carolina.

are less than 26 hours, which may be insufficient to produce scour depths comparable to laboratory investigations that run for several days or longer.

The relation of abutmentscour depth and the estimated peak-flow duration for the 100-year flow (Bohman, 1990) for bridges in the Piedmont is shown in figure 37B. [Two outlying data points were excluded from this figure (reference number 89 and 90 , appendix B, fig. 1).] Data were grouped into three categories based on embankment length. The envelope curves of these categories are relatively flat implying that peak-flow duration in the Piedmont may have only minor effects on abutment-scour depths. Comparing the Coastal

To provide some perspective on the relation of abutment-scour depth and peak-flow duration for field data, figure 37A shows the relation of abutment-scour depth and the estimated peak-flow duration for the 100-year flow at single-bridge openings in the Coastal Plain. The peak-flow duration for each site was estimated by using methods presented in Bohman (1990), assuming that the hydrograph duration at 95 percent of the 100-year flow represented the duration for the 100-year peak flow. Multiple-opening bridges were excluded from this figure because two-dimensional flow patterns at such sites can vary from the typical single-bridge opening. Data were grouped into three categories: (1) scour holes with embankment lengths less than or equal to $400 \mathrm{ft}$, (2) scour holes with embankment lengths less than or equal to $600 \mathrm{ft}$, but greater than $400 \mathrm{ft}$, and (3) scour holes with embankment lengths less than or equal to $5,300 \mathrm{ft}$, but greater than $600 \mathrm{ft}$. As can be seen in figure 37A, there is a large scatter of data within these three categories; however, the envelope curves, drawn to encompass the data in each category, are relatively flat implying that the effect of peak-flow duration on abutment-scour depths may only have a minor effect for the range of peak-flow durations in this study. It is noteworthy that all peak-flow durations for the simulated hydrographs
Plain and Piedmont plots highlights the difference in peak-flow duration between these regions. A large part of the Piedmont sites have peak-flow durations less than 5 hours in contrast to those in the Coastal Plain that exceed 5 hours. As with the Coastal Plain, figure 37B shows that Piedmont peak-flow durations may be insufficient to produce scour comparable to laboratory investigations that run for several days or longer.

\section{Flow Velocity}

Laboratory investigations indicate that clear-water abutment-scour depths increase with increasing approach velocity (Dongol, 1993). Figure 38 (Dongol, 1993) presents a typical laboratory relation of flow velocity and equilibrium-scour depth for uniform sediments. The shape of this curve is slightly different for nonuniform sediments because of the effect of armoring, but the trends are similar. The vertical axis in figure 38 represents the equilibrium-scour depth normalized by the embankment length. The horizontal axis represents flow intensity, which is defined as the ratio of the average approach flow velocity $(\mathrm{U})$ to the critical average velocity $\left(\mathrm{U}_{\mathrm{c}}\right)$ required to initiate motion of the given sediment. For clear-water scour conditions, the flow intensity will be less than 1 , with the transition 
A.

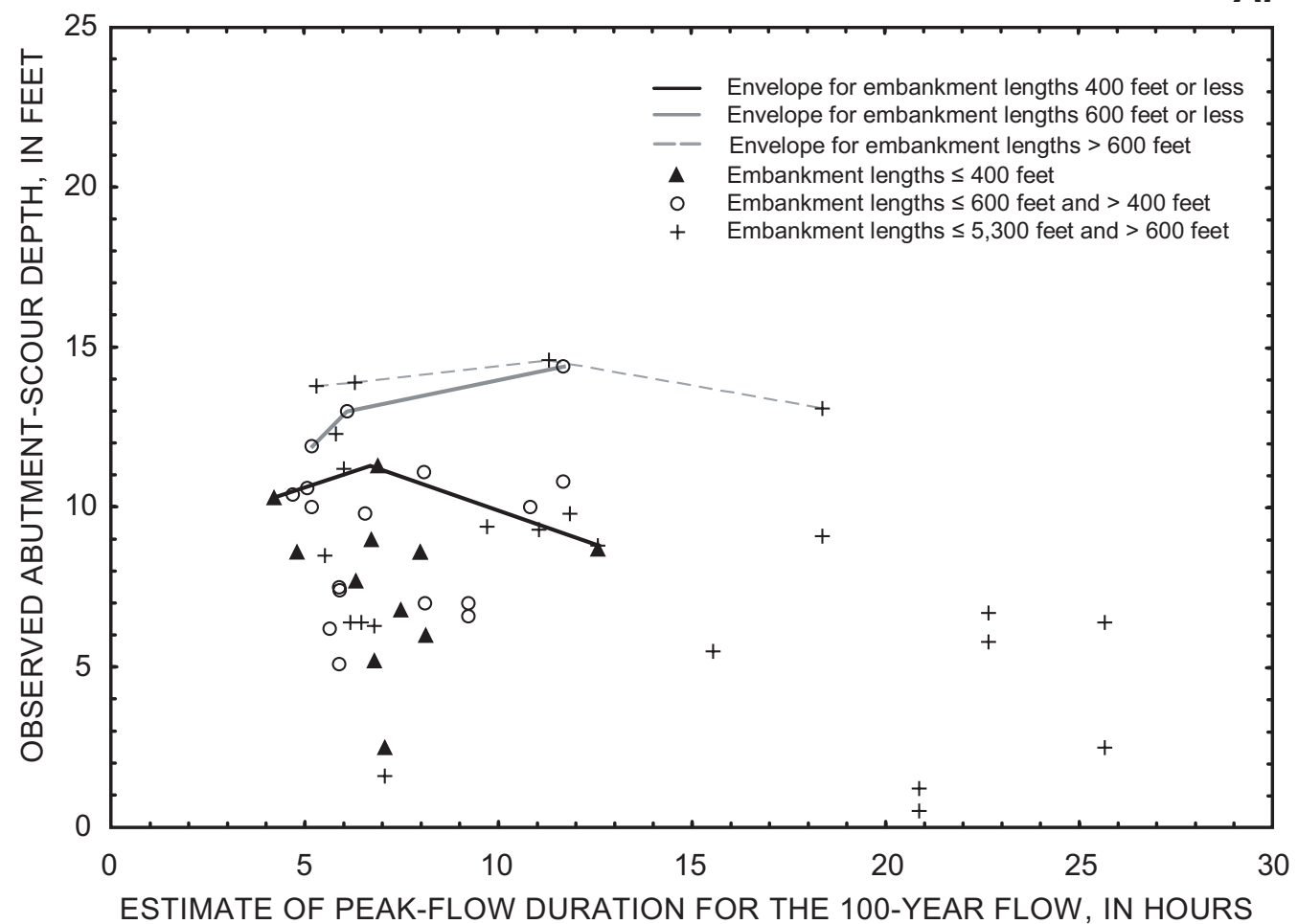

B.

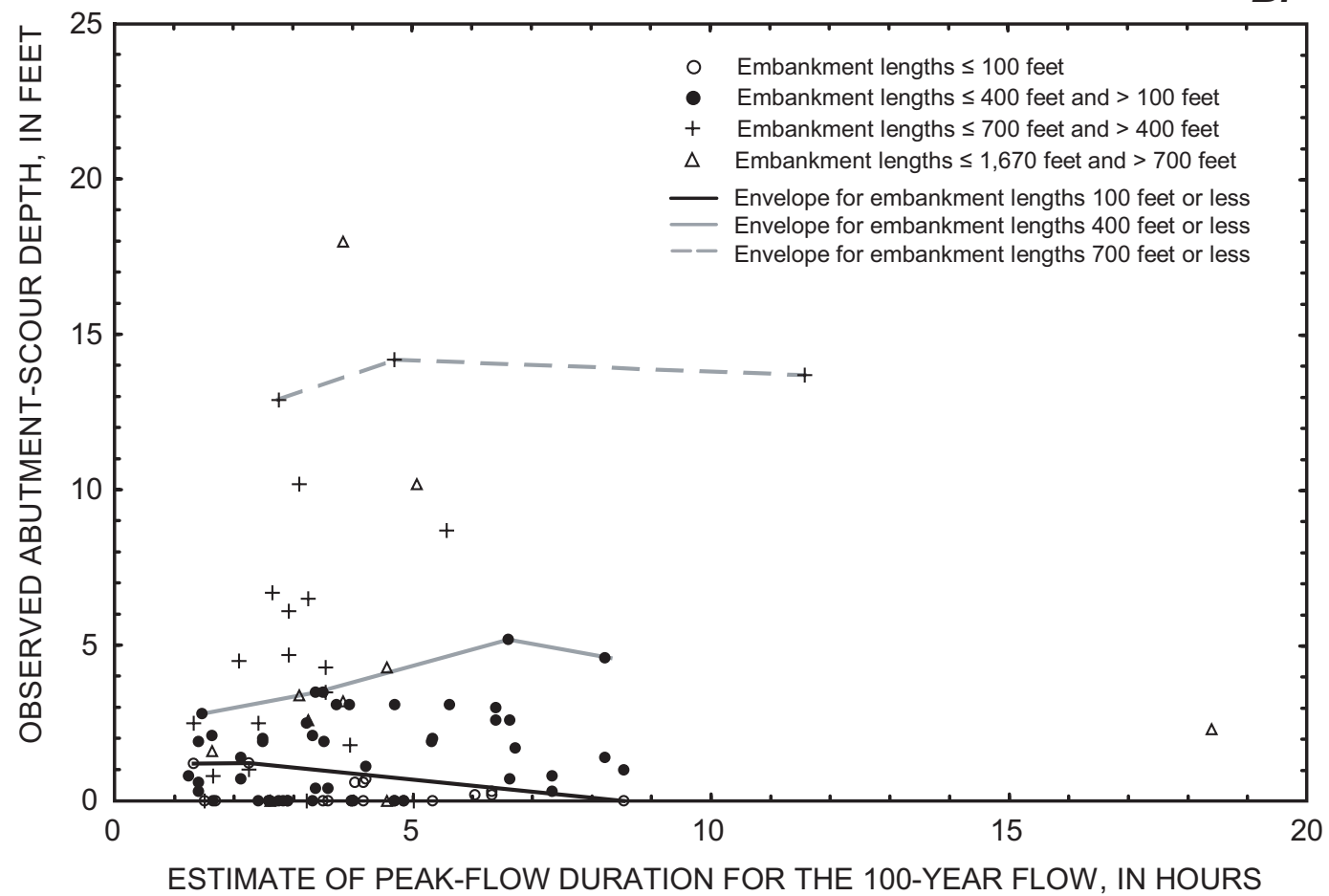

Figure 37. Relation of observed clear-water abutment-scour depth and the estimated peak-flow duration for the 100-year flow at single-bridge openings in the (A) Coastal Plain and (B) Piedmont of South Carolina. 


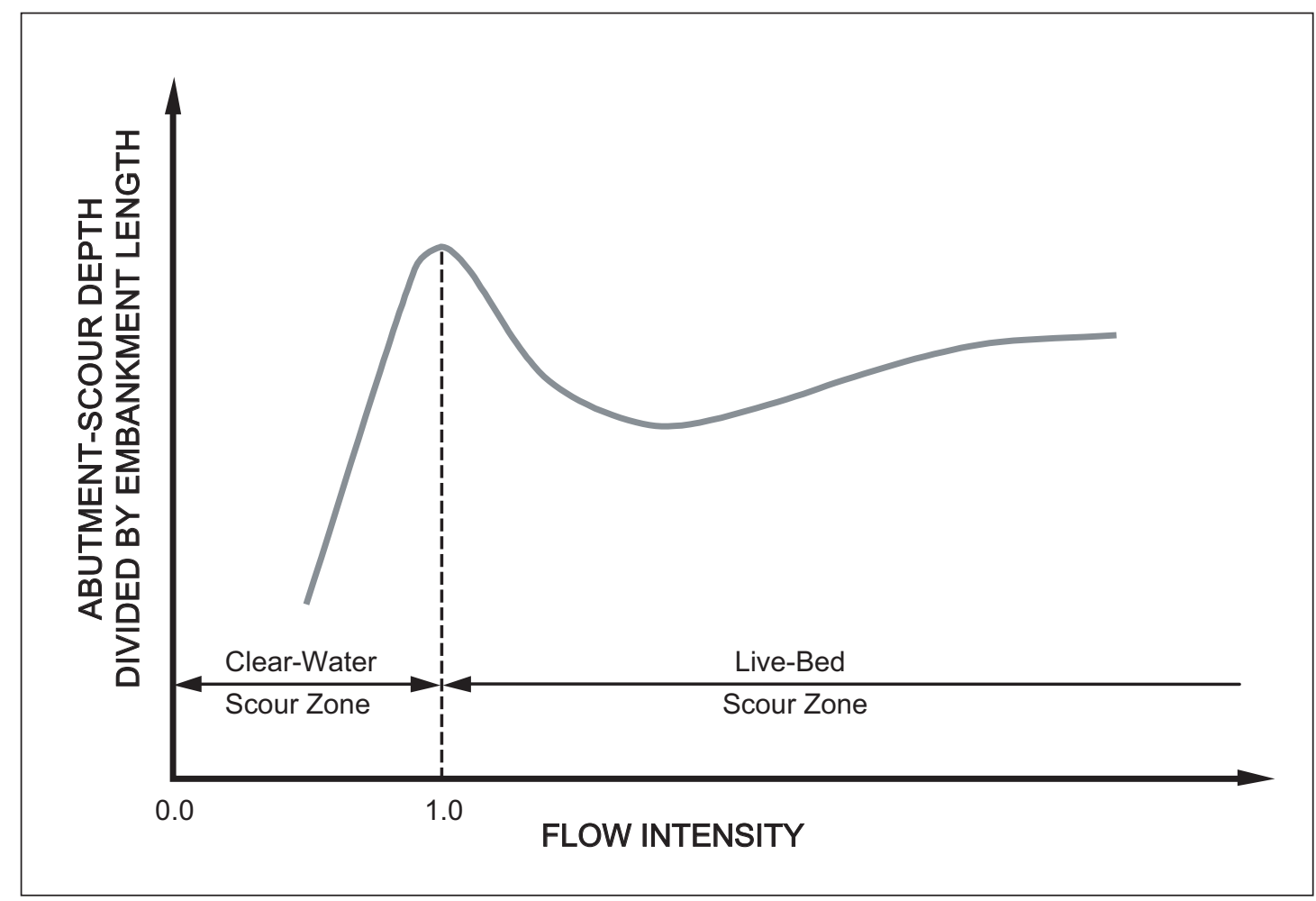

Not to Scale

Figure 38. General relation of flow intensity and abutment-scour depth normalized by embankment length based on laboratory data. (From Dongol, 1993.)

from clear-water to live-bed scour occurring when the flow intensity equals 1 . The curve in the area of clearwater scour has a relatively steep slope, indicating that small changes in approach velocity can produce relatively large changes in scour depth when other variables remain constant.

Figure 39 shows selected laboratory data for spill-through abutments (Dongol, 1993) grouped by the dimensionless variable of flow depth divided by embankment length. The patterns are similar to that depicted in figure 38 . Figure 39 also shows the relation of flow intensity (based on the 100-year obstructed approach velocity) and normalized scour depth for field observations in the current study. [The critical velocity, $\mathrm{U}_{\mathrm{c}}$, was determined from the relation published by Vanoni (1977) using the $\mathrm{D}_{50}$ for the unscoured surface soils at each site. The critical velocities were not adjusted for flow depth.] The field data show no strong relation, and actually indicate that the effect of velocity on abutment-scour depth may be minor. This relation in the field data should be viewed with some caution because of potential errors associated with the $\mathrm{D}_{50}$ and the estimated flow velocities. Soils in this study were heterogeneous, and grab samples used to determine the $\mathrm{D}_{50}$ might not properly represent the average soil characteristics at a given site. Error associated with the grain size will, in turn, introduce error in the estimate of the critical velocity. In addition, the flows that produced the measured scour are unknown, and the estimated flow velocities obtained from the WSPRO (Shearman, 1990) model may have some error. Cohesive soils of the Piedmont might also introduce some discrepancy with the laboratory relations that were developed for loosegrained soils.

Despite these potential errors within the field data, figure 39 provides a good indication for the range of dimensionless variables that should be anticipated for field conditions in South Carolina. As can be seen, the range for the normalized abutment-scour depth for the laboratory data does not encompass the range for the field data, making it difficult to apply the laboratory relations to field conditions. Although the laboratory data shown in figure 39 are only a subset of all the laboratory data, the subset implies that many laboratory investigations of abutment scour do not encompass the range of dimensionless variables typically found in the field. 


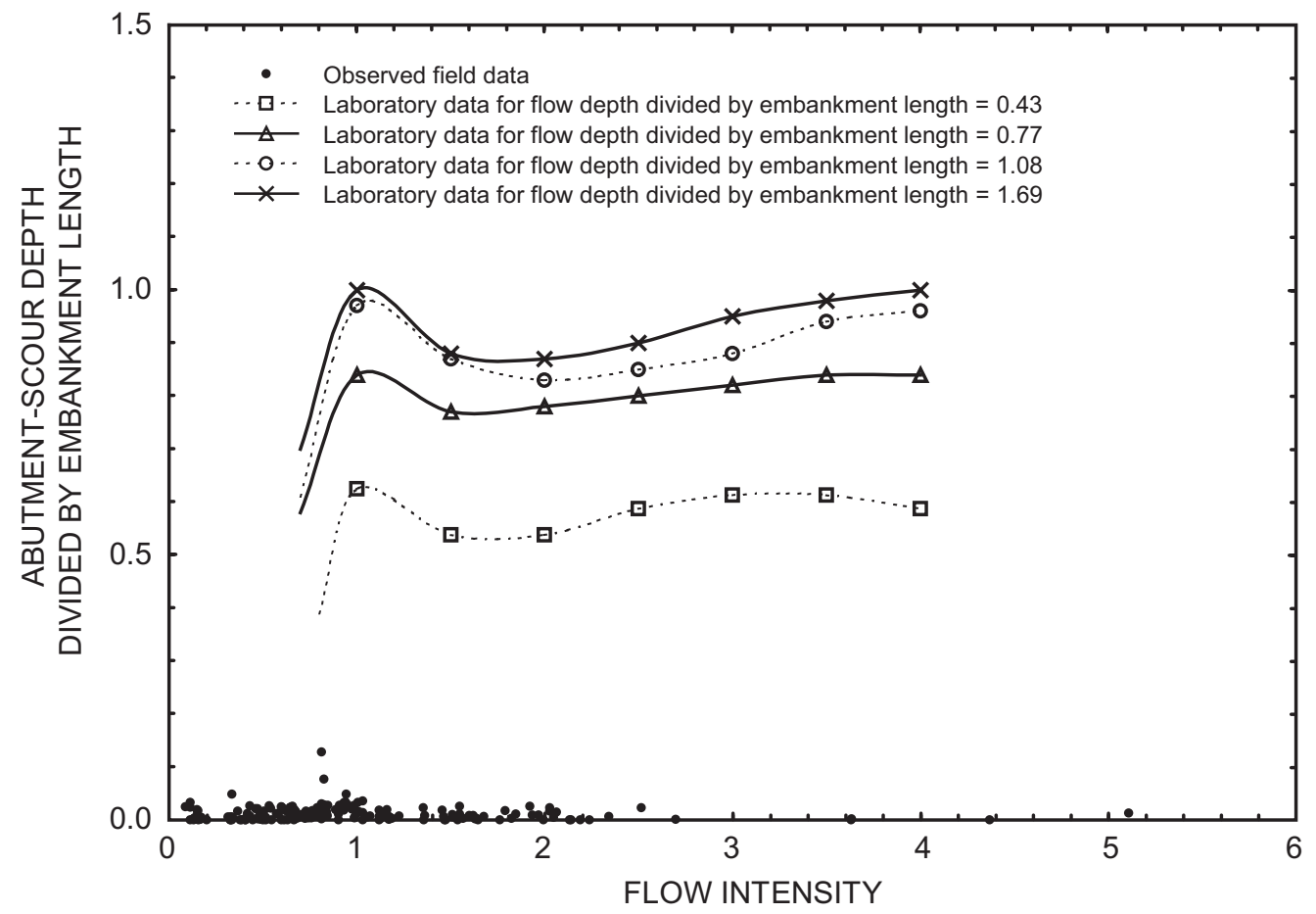

Figure 39. Relation of abutment-scour depth, normalized by embankment length, and flow intensity for laboratory data (Dongol, 1993) and observed data in the Piedmont and Coastal Plain of South Carolina.

Therefore, abutment-scour relations developed from laboratory data may not translate well to field conditions.

To provide some perspective on the relation of abutment-scour depth and approach velocity for nonnormalized field data, figure $40 \mathrm{~A}$ shows the relation of abutment-scour depth and the average 100-year flow velocity obstructed by the embankment for singlebridge openings in the Coastal Plain. Data were grouped into three categories similar to the peak-flow duration relation in figure 37A. Envelope curves were developed for these categories assuming that an approach-flow velocity of $0.0 \mathrm{ft} / \mathrm{s}$ would produce $0.0 \mathrm{ft}$ of scour. As can be seen in figure 40A, there is a large scatter of data within these three categories; however, the envelope curves drawn to encompass the data of these categories display a relation that indicates an increase in abutment-scour depth with increasing approach velocity, which is consistent with laboratory investigations of clear-water abutment scour (figs. 38 and 39). The slopes of the three envelope curves are relatively flat for the range of the 100-year-flow velocities between 0.3 to $0.7 \mathrm{ft} / \mathrm{s}$. This indicates that abutment-scour depth in the Coastal Plain may be relatively insensitive for this range of approach velocity. If the extrapolation of the envelope curves to zero is correct, then abutment-scour depth will be more sensitive for velocities less than $0.3 \mathrm{ft} / \mathrm{s}$, and small changes in approach velocity in this area will produce relatively large changes in abutment-scour depth.

In general, the slopes of the envelope curves increase with increasing embankment length. Because larger scour depths are associated with longer embankment lengths, this trend appears reasonable. This trend is also consistent with the theory of hydrodynamics. For a constant-approach flow velocity, an increase in embankment length will produce an increase in velocity at the tip of the abutment (fig. 34), which then produces an increase in potential for scour. As a result, for a constant-approach flow velocity, larger scour depths at longer embankments are expected.

Figure 40B shows the relation of abutmentscour depth and the average 100-year-flow velocity obstructed by the abutment for bridges in the Piedmont. (Two outlying data points were excluded from this figure.) Data were grouped into three categories similar to the peak-flow duration relation in figure 37B. 
A.

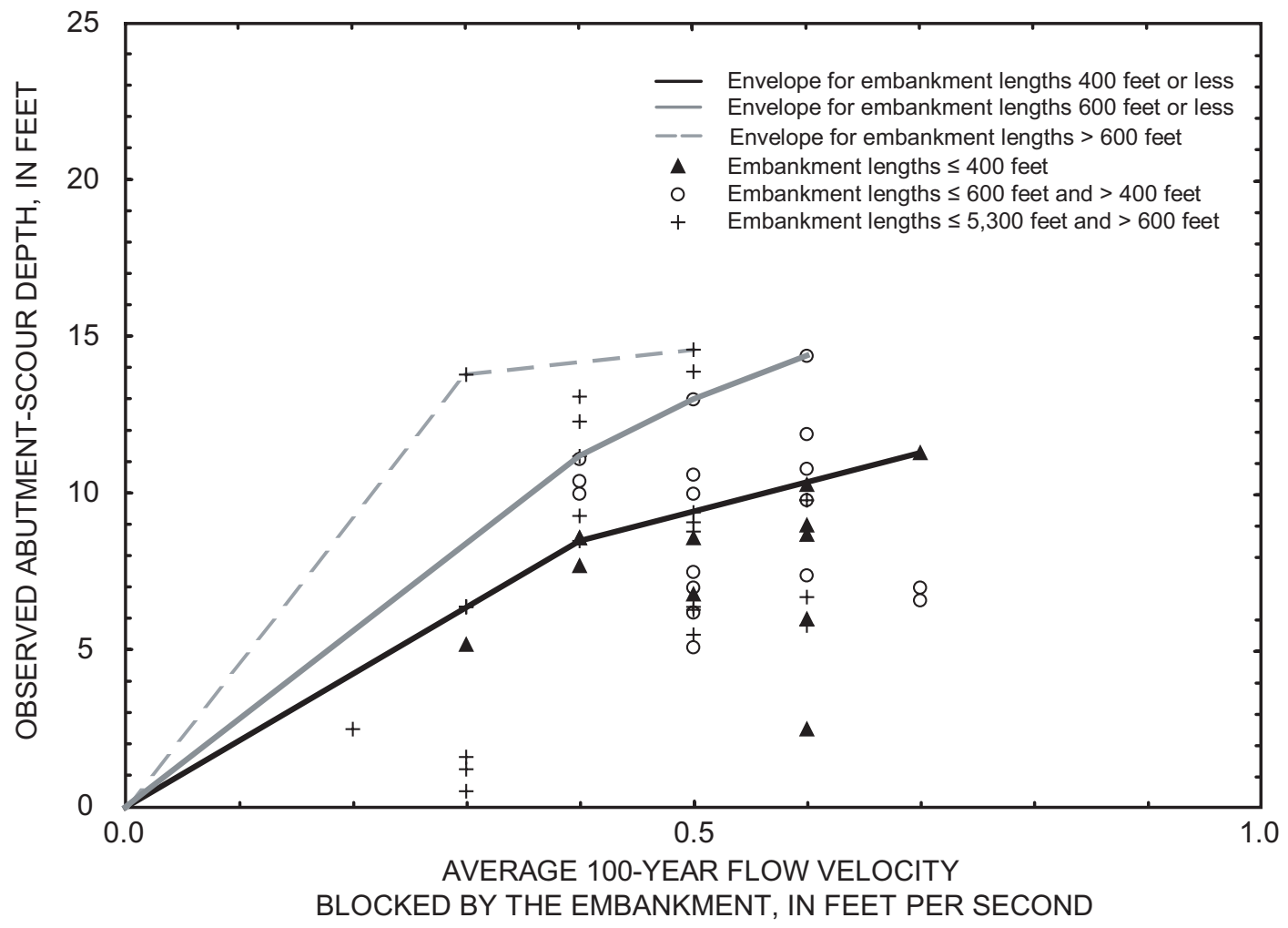

B.

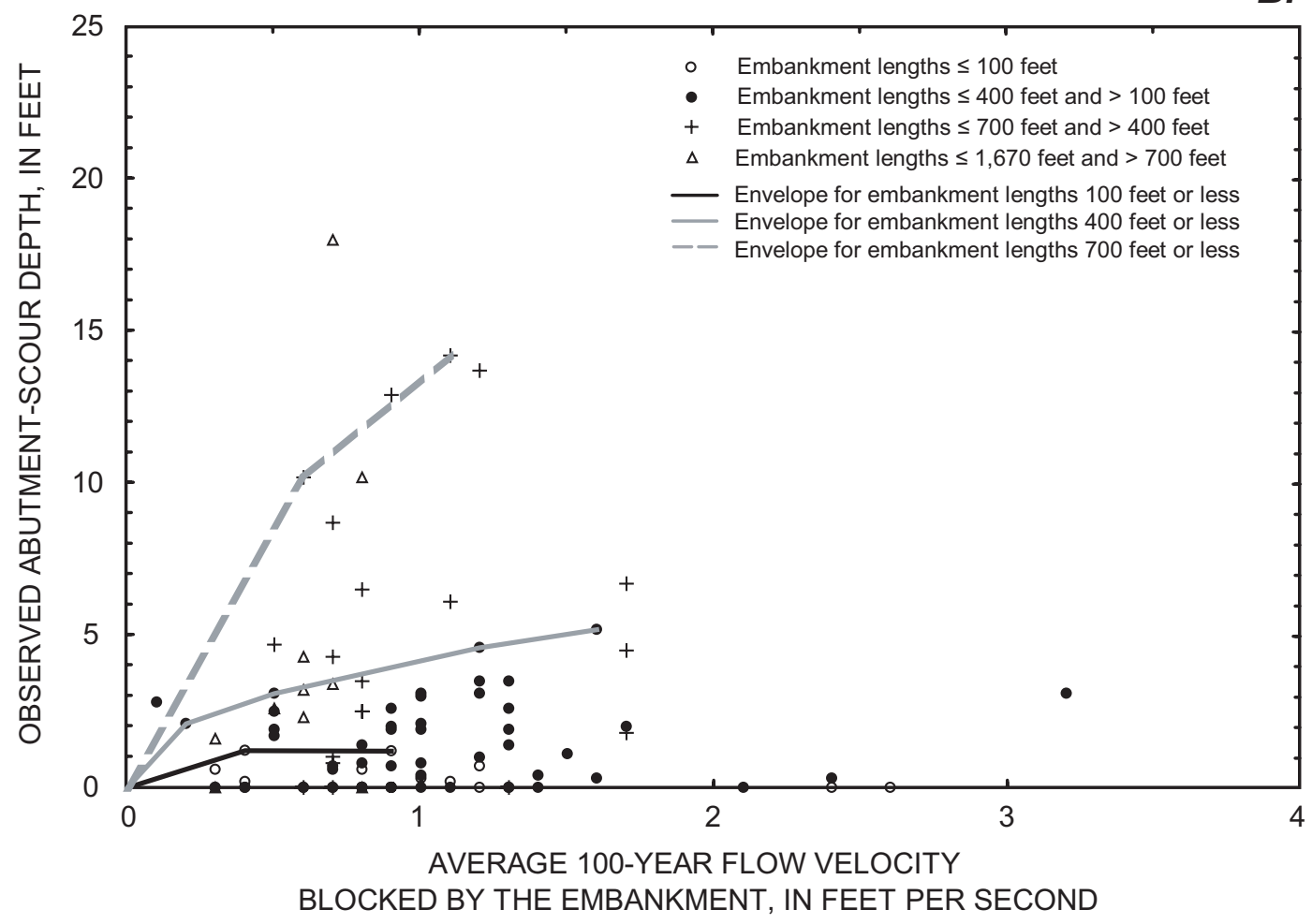

Figure 40. Relation of observed clear-water abutment-scour depth and the average 100-year-flow velocity, blocked by the embankment, at single-bridge openings in the (A) Coastal Plain and (B) Piedmont of South Carolina. 
The trends are similar to those in the Coastal Plain (fig. 40A); however, there are some notable differences. A comparison between figures $40 \mathrm{~A}$ and $40 \mathrm{~B}$ shows that velocities in the Piedmont will, in general, exceed those in the Coastal Plain. This can be attributed to steeper stream slopes associated with Piedmont streams (fig. 2). In addition, envelope curves for comparable embankment lengths indicate that a given approach velocity will produce larger scour depths in the Coastal Plain than the Piedmont. This is particularly obvious for embankment lengths of $400 \mathrm{ft}$ or less (fig. 41A). The difference between the envelope curves can most likely be attributed to the cohesive nature of the Piedmont soils compared to the sandy soils of the Coastal Plain. Figure 41A shows that the cohesive Piedmont soils can sustain higher velocities and will produce smaller scour depths in contrast to the sandy soils of the Coastal Plain. This provides some perspective of the effect of soil cohesion on abutment scour. Comparing the Piedmont envelope for embankment lengths of $700 \mathrm{ft}$ or less with the Coastal Plain envelope for embankment lengths of 600 $\mathrm{ft}$ or less (fig. 41B) shows that the Coastal Plain still has larger scour depths at embankment lengths exceeding $400 \mathrm{ft}$. The difference between these envelope curves, however, is less than the envelope curves for embankment lengths of $400 \mathrm{ft}$ or less. This indicates that the scour patterns in the Piedmont approach those of the Coastal Plain as embankment length increases.

\section{Flow Depth}

Laboratory investigations indicate that clearwater abutment-scour depths increase at a diminishing rate with increasing flow depth (Dongol, 1993). This trend is shown in figure 42 (Dongol, 1993) where a best-fit line through selected laboratory data for spillthrough abutments with uniform sediments is plotted. The scour and flow depth variables have been normalized by the embankment length. Although figure 42 represents a subset of laboratory data from previous investigations, it provides insight regarding the hydraulic conditions under which these investigations were typically made. The ranges for the normalized flow depth and the normalized scour depth for the selected laboratory data are 0.1 to 1.7 and 0.3 to 1.0 , respectively. In contrast, the ranges of these dimensionless variables for 207 of the 209 field observations of abutment scour (204 are spill-through abutments) are 0.0016 to 0.54 and 0.0 to 0.13 , respectively. As can be seen from figure 42 , all of the field data fall outside the limits of the selected laboratory data, indicating that laboratory experiments do not cover the range of field variables typically found in South Carolina. Because the normalizing variable in figure 42 is embankment length, it is likely that the range discrepancy between laboratory and field data can be attributed to the use of relatively short embankments in laboratory studies in contrast to relatively long embankments found in the field. Because the South Carolina field data fall outside the range of laboratory data, it is difficult to draw conclusions on what effect flow depth will have on scour depths under field conditions. However, the concentration of field data in the lower left-hand corner of figure 42 may indicate that flow depth has only a minor effect on abutment-scour depths in South Carolina.

To provide some perspective on the relation of abutment-scour depth and flow depth for non-normalized field data, figure 43A shows the relation of abutment-scour depth and the 100-year flow-depth near the abutment toe, for single-bridge openings in the Coastal Plain. Data were grouped into three categories similar to the peak-flow duration relation presented in figure 37A. As can be seen, there is a large scatter of data within these three categories and the range of the 100year-flow depth for the majority of the data is relatively small (4 to $8 \mathrm{ft}$ ). Envelope curves for embankment lengths of $400 \mathrm{ft}$ or less and $600 \mathrm{ft}$ or less show a small increase in scour depth with increase in flow depth. The increase is relatively small implying that abutment-scour depth in the Coastal Plain is relatively insensitive for this range of 100-year-flow depths.

The relation of abutment-scour depth and the 100-year-flow depth near the abutment toe for bridges in the Piedmont is shown in figure 43B. Data were grouped into categories similar to the peak-flow duration relation presented in figure 37B. The envelope curves in this figure generally show a small increase in abutment-scour depth with increasing flow depth. The exception to this is for embankment lengths of $100 \mathrm{ft}$ or less where observed scour depths drop slightly with increasing flow depth. Regardless, all three envelope curves indicate that abutment-scour depth in the Piedmont is relatively insensitive to flow depth. 
A.

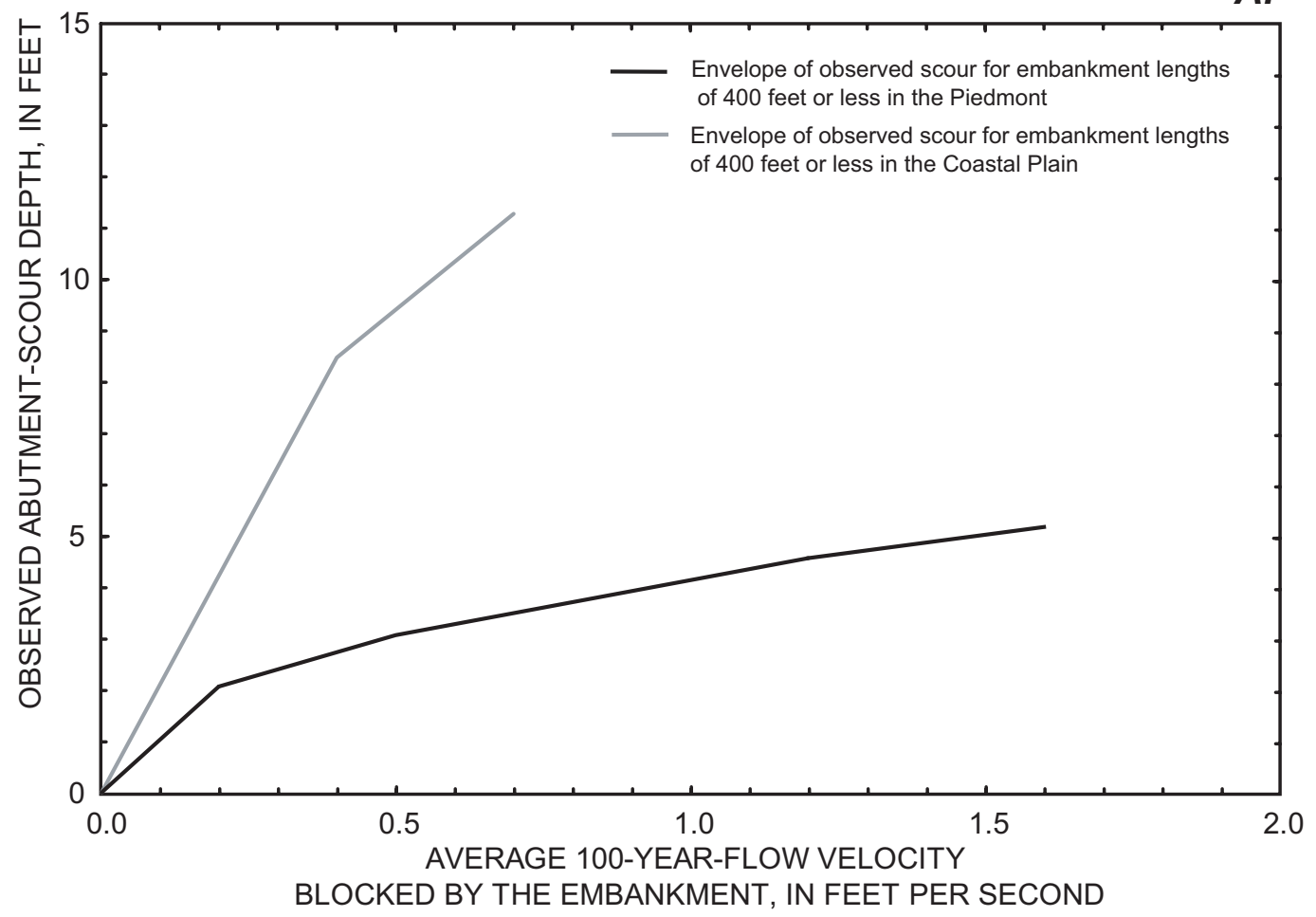

B.

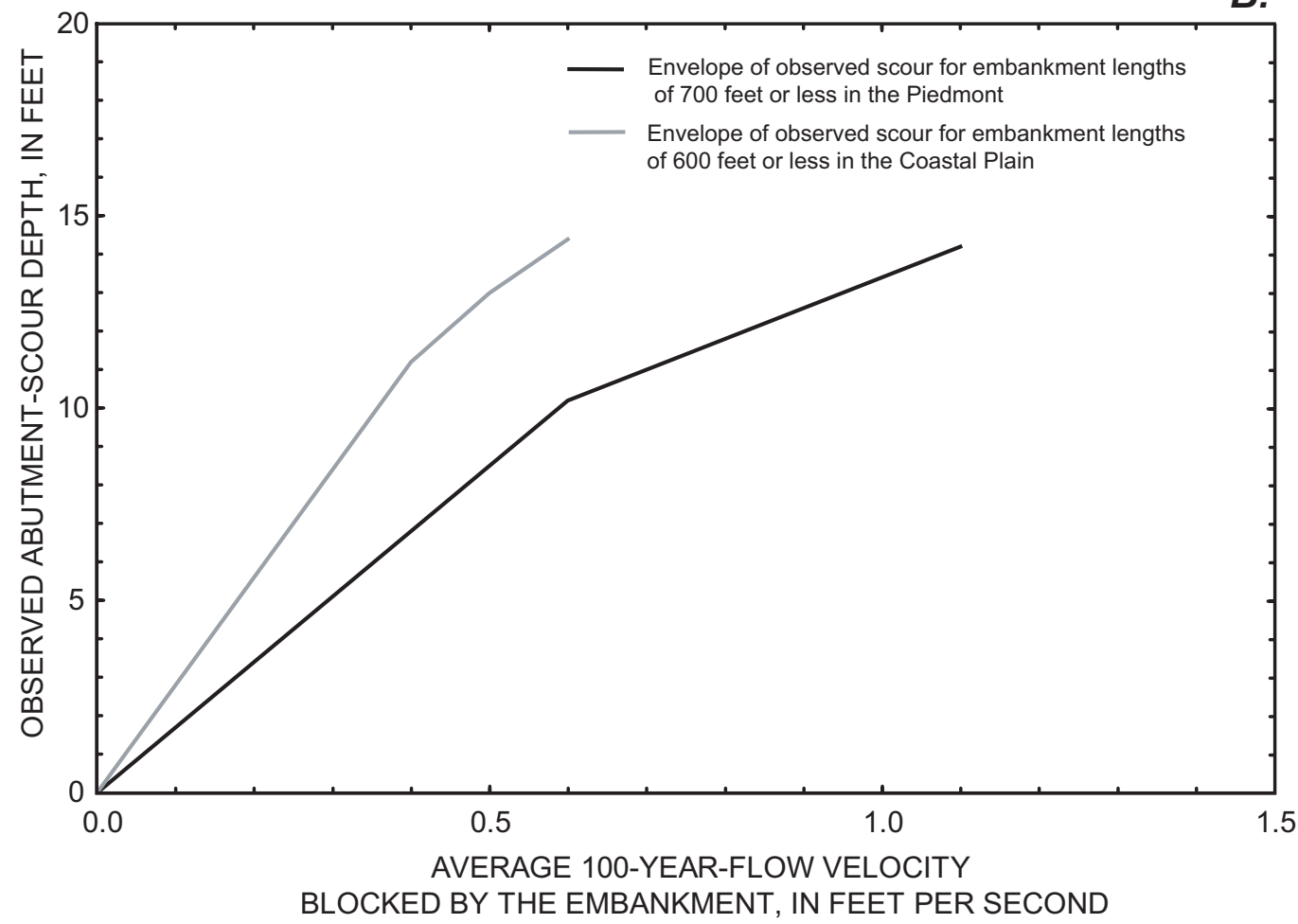

Figure 41. Comparison of envelopes for the relation of observed clear-water abutment-scour depth and the average 100-year-flow velocity, blocked by the embankment, for $(A)$ embankment lengths of 400 feet or less in the Coastal Plain and Piedmont, and (B) embankment lengths of 600 feet and 700 feet or less in the Coastal Plain and Piedmont of South Carolina, respectively. 


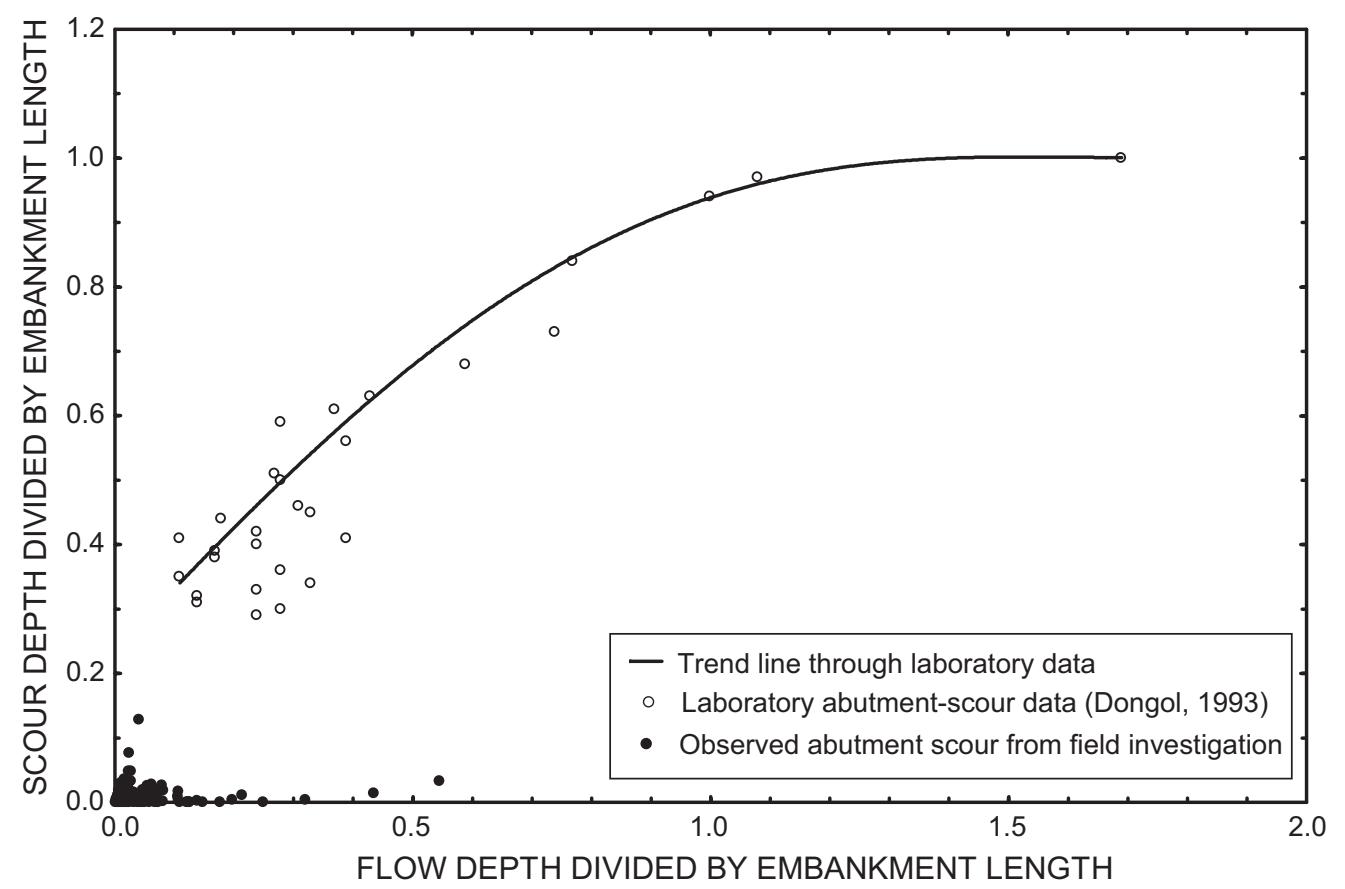

Figure 42. Relation of clear-water abutment-scour depth and flow depth, normalized by embankment length, for selected laboratory data at spill-through abutments (Dongol, 1993) and field data collected in the Piedmont and Coastal Plain of South Carolina.

\section{Sediment Size}

Although numerous properties influence the process of clear-water abutment-scour, laboratory data suggest that, as the embankment length increases, the influence of some properties diminishes and may become negligible (Melville, 1992). Sediment size is one property that functions in such a manner. For uniform noncohesive sediments, laboratory studies show that the influence of sediment size on scour-hole depths diminishes with increasing embankment length. When the dimensionless ratio of embankment length (L) to median grain size $\left(\mathrm{D}_{50}\right)$ is greater than or equal to 50, the effect of sediment size on equilibrium-scour depths becomes negligible (Dongol, 1993). Although soils in South Carolina are not uniform and commonly have some degree of cohesion, a computation of this dimensionless variable provides some insights into the effect of sediment size on abutment scour in South Carolina. For the 209 observations of abutment scour in this study, $\mathrm{D}_{50}$ ranges from 0.007 to $0.990 \mathrm{~mm}$, $\mathrm{L}$ ranges from 18 to $7,440 \mathrm{ft}$, and the dimensionless variable $\mathrm{L} / \mathrm{D}_{50}$ ranges from $4.4 \times 10^{4}$ to $7.3 \times 10^{7}$. The range of $\mathrm{L} / \mathrm{D}_{50}$ greatly exceeds 50 , indicating that the sediment sizes typically found in South Carolina may have negligible influence on equilibrium-scour depths because embankment lengths are relatively long.

To provide some perspective on the relation of abutment-scour depth and median grain size for nonnormalized field data, figure 44A shows the relation of abutment-scour depth and the median grain size for surface soils at single-bridge openings in the Coastal Plain. Data were grouped into three categories similar to the peak-flow duration relation presented in figure $37 \mathrm{~A}$, and the scatter within these categories is fairly large. In general, the envelope curves indicate an increase in scour depth with increasing grain size, which seems counterintuitive. Perhaps one explanation for this trend is that the smaller grain sizes are associated with more cohesive soils, which reduce the potential for scour. An example of this can be seen at Structure 342050100300 on U.S. Route 501, crossing Smith Swamp in Marion County, which is identified on figure 44A. The site has a clayey soil that may reduce the amount of scour. If this site had noncohesive soils, scour depths would be more in line with sites having larger median grain sizes. Excluding Smith Swamp, the general increase in scour depth with increasing 
A.

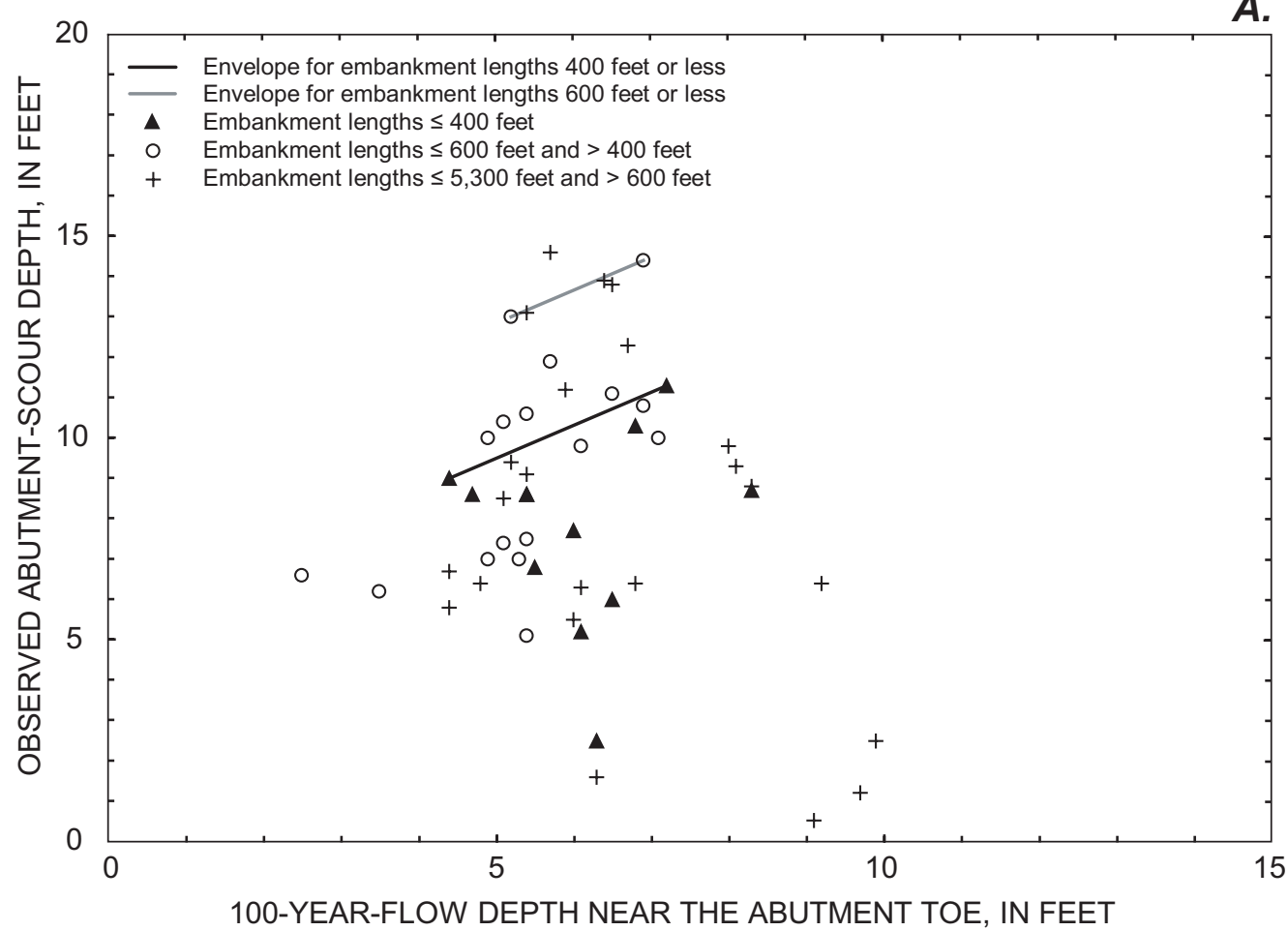

B.

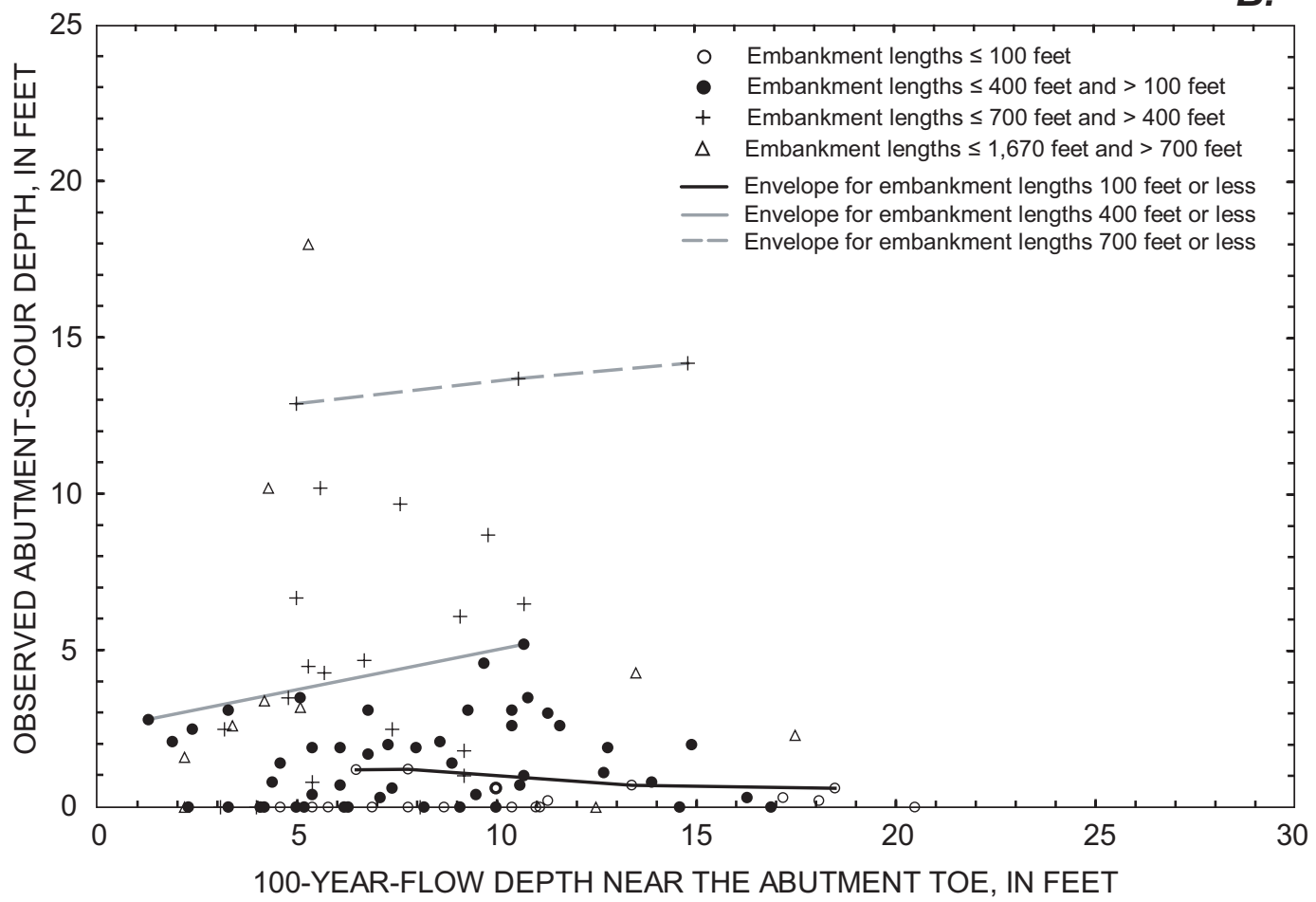

Figure 43. Relation of observed clear-water abutment-scour depth and the 100-year-flow depth near the abutment toe for single-bridge openings (A) in the Coastal Plain and (B) Piedmont of South Carolina. 
A.

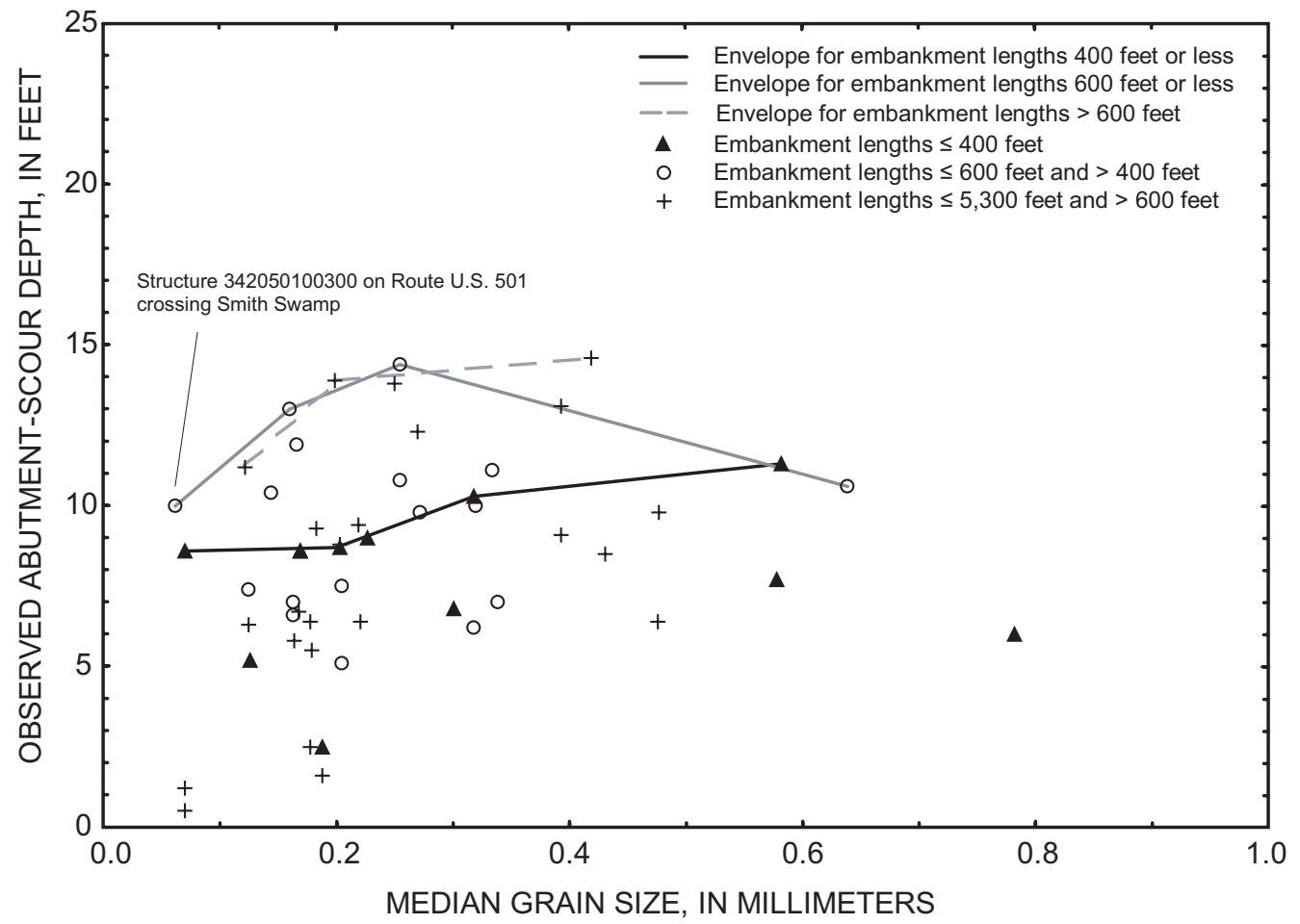

B.

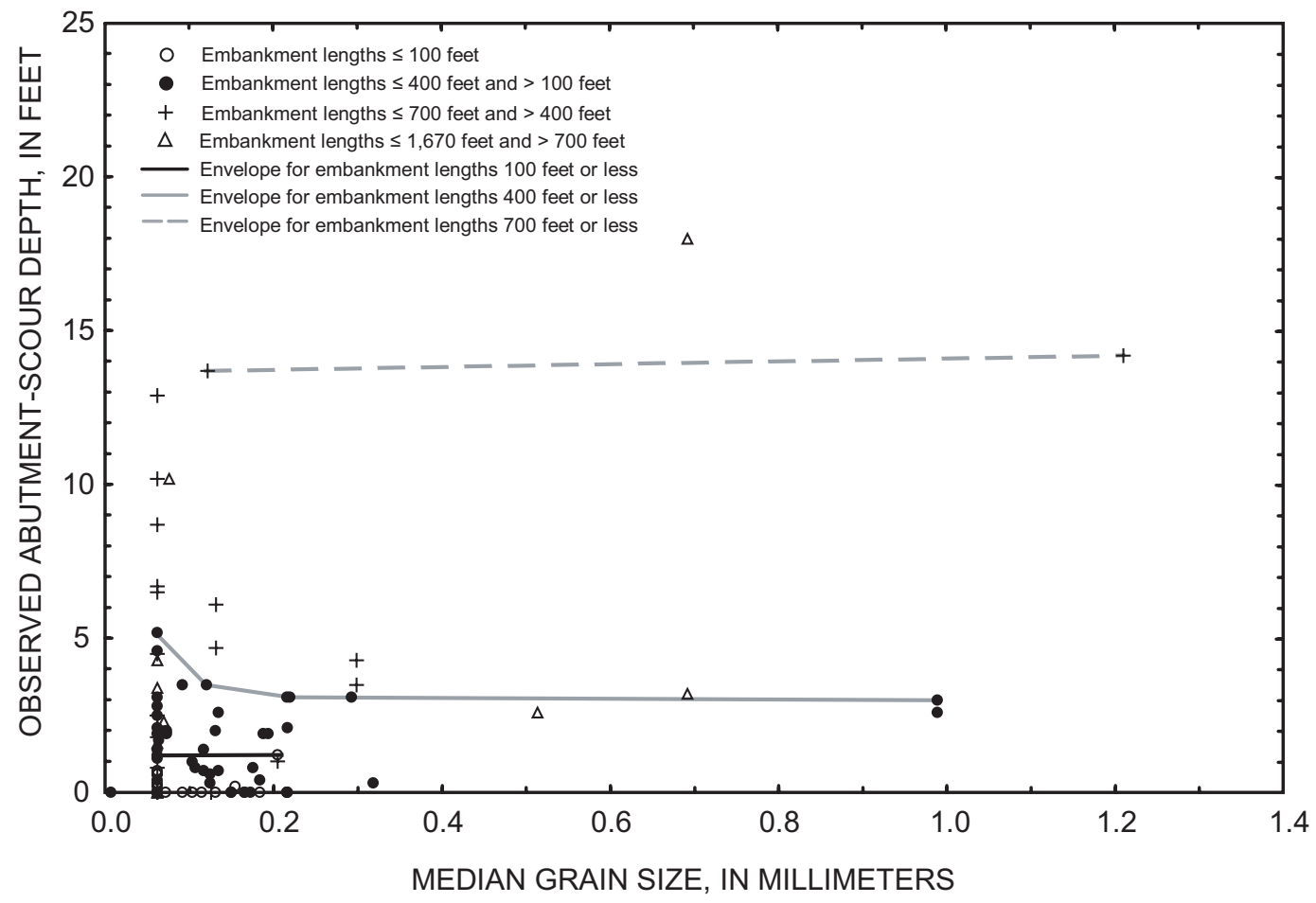

Figure 44. Relation of observed clear-water abutment-scour depth and the median grain size of the original sediment sample for surface soils at single-bridge openings in the (A) Coastal Plain and (B) Piedmont of South Carolina. 
sediment size is relatively small, and it is likely that the effect of sediment size is minimal for the range of $D_{50}$ observed in the Coastal Plain.

The relation of abutment-scour depth and the median grain size for the original sample of the surface soils at bridges in the Piedmont is shown in figure 44B. Data were grouped into categories similar to the peakflow duration relation presented in figure 37B. (S.C. Route 97 crossing Turkey Creek in Chester County had a thin layer of clayey surface soils overlying sand. Because the sandy soil was the dominant soil type, the $D_{50}$ for the sandy soil was used in figure 44B instead of the $\mathrm{D}_{50}$ for the clayey surface soil.) The envelope curves in figure 44B generally show little change in abutment-scour depth with increasing median grain size. For embankment lengths of 100 or $400 \mathrm{ft}$ or less, the soils are clayey and fairly cohesive. Therefore, the flat nature of these envelope curves may likely be attributed to cohesion. Longer embankment lengths associated with wider floodplains also have clayey soils, but are commonly more sandy or have a relatively high moisture content reducing the degree of cohesion. Because of the large scatter within the data for embankment lengths greater than $400 \mathrm{ft}$, it is difficult to draw strong conclusions about the effect of grain size on scour depths. If the envelope for embankment lengths of $700 \mathrm{ft}$ or less is correct, then the effect is minimal.

\section{Sediment Gradation}

The above observation is for uniform sediments and, therefore, the effects of armoring that are often encountered with graded soils may influence scour depths at a given site. However, if the largest grain size of a graded sediment is too small to armor the streambed, then the effect of gradation is insignificant. If the dimensionless ratio $\mathrm{L} / \mathrm{D}_{\max }$ equals or exceeds 50 , then it would seem reasonable to assume that grain sizes $\leq \mathrm{D}_{\max }$ (and thus gradation) will have negligible influence on equilibrium-scour depths. Because the sediment size associated with the 84th percentile by weight $\left(D_{84}\right)$ was available in the bridge-scour database, the $\mathrm{D}_{84}$ was assumed to represent the largest grain size for a given soil. Although the $\mathrm{D}_{84}$ will be smaller than the $\mathrm{D}_{\max }$, it is near the upper limits of the grain size range and should give insights into the effects of gradation. For the 209 observations of abutment scour in South Carolina, the $\mathrm{D}_{84}$ ranges from 0.040 to $3.80 \mathrm{~mm}$ and the dimensionless ratio, $\mathrm{L} / \mathrm{D}_{84}$, ranges from $1.6 \times 10^{4}$ to $1.2 \times 10^{7}$. Because the dimensionless ratio $\mathrm{L} / \mathrm{D}_{84}$ greatly exceeds 50 , it is perhaps reasonable to assume that the effect of sediment gradation on equilibrium abutment-scour depths for South Carolina sites is negligible.

\section{Embankment Length}

Dongol (1993) states that, "Abutment length is one of the most important parameters influencing the process of local abutment scour." (Many laboratory investigations, including Dongol, define the road embankment that blocks approaching flows as the abutment length; however, in this report, the term embankment length is used.) Laboratory data show that scour depth increases logarithmically with embankment length and will approach a value beyond which embankment length has minimal influence on scour depth (Dongol, 1993). Figure 45 shows the relation of embankment length and scour depth, normalized by flow depth, for laboratory data collected at a flow intensity $\left(\mathrm{U} / \mathrm{U}_{\mathrm{c}}\right)$ of 1 (Melville, 1992). The plot shows an increase of scour depth with increasing embankment length with an asymptotic limit of about 10 . Melville notes that the limit of 10 for the scour depth to flow depth ratio is likely too high for field conditions, and states that a maximum ratio of 4 was observed for limited field data along the Mississippi River (Richardson and others, 1990).

Figure 46A shows the South Carolina field data plotted in a similar manner to Melville (1992). The observed abutment-scour depth and the 100-year-flow embankment length have been normalized by the 100-year-flow depth near the abutment toe. To provide a better comparison of the smaller normalized embankment lengths, figure 46B shows the same data with a truncated horizontal axis. The field data show a similar trend to the laboratory relation, but there is more scatter within the field data and the limit of 3.4 is significantly lower. The scatter within the field data may, in part, be attributed to flow intensities not equaling 1 , and to varying degrees of soil cohesion. Note that the maximum ratio of scour depth to flow depth for the South Carolina field data (3.4) is relatively close to the maximum ratio of 4 observed along the Mississippi River (Richardson and others, 1990). These observed scour depth to flow depth ratios in South Carolina and along the Mississippi River need additional verification; however, they provide some perspective on the range of maximum abutment-scour depths observed in the field in contrast to laboratory data. 


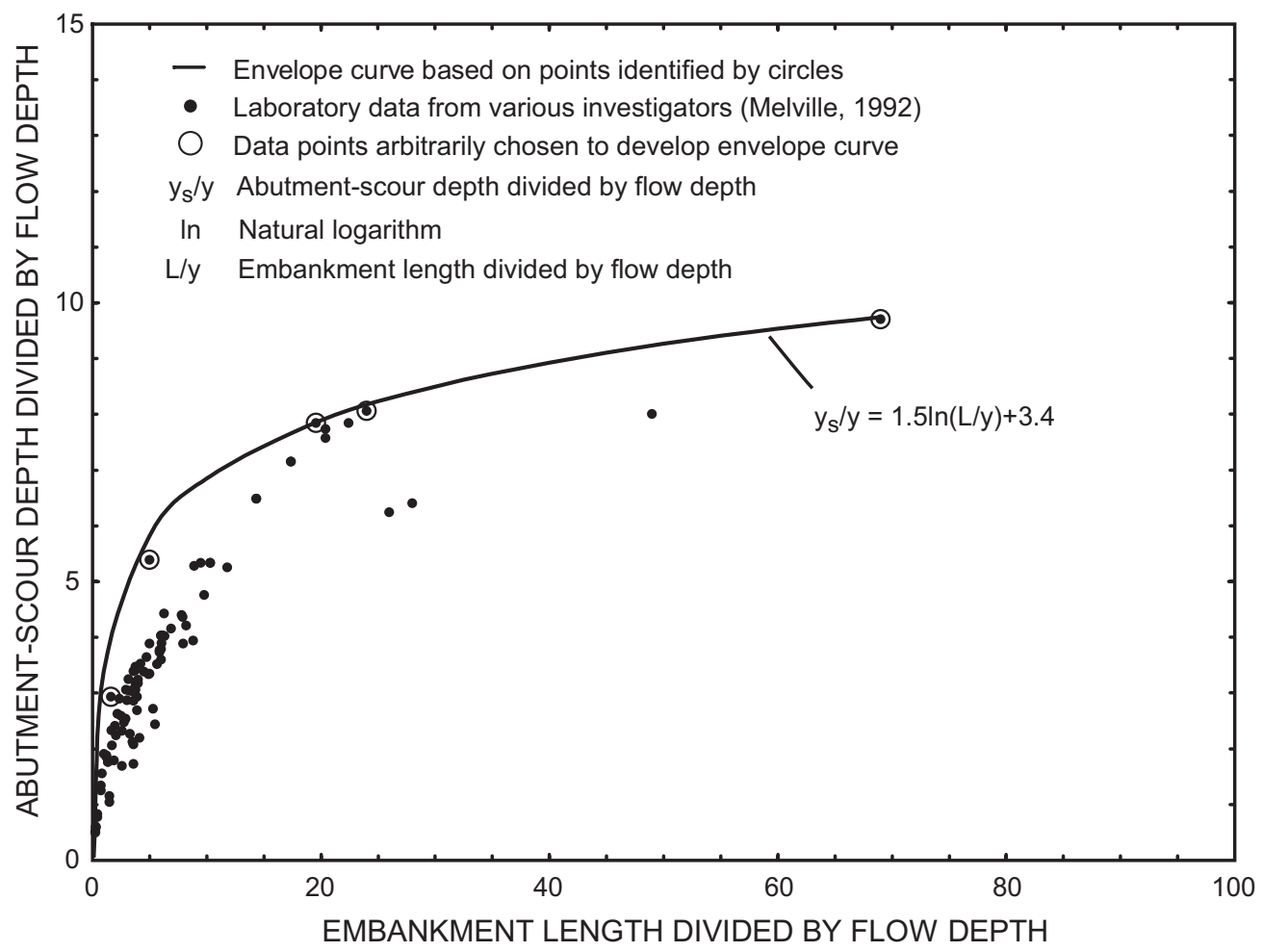

Figure 45. Relation of abutment-scour depth and embankment length, normalized by flow depth, for laboratory data collected at flow intensities of 1. (Modified from Melville, 1992.)

Using the laboratory data presented in figure 45, Melville (1992) defined three classes of abutments based on the dimensionless ratio of embankment length (L) to flow depth (y): (1) abutments with short embankments $(\mathrm{L} / \mathrm{y}<1),(2)$ abutments with intermediate embankments $(1 \leq \mathrm{L} / \mathrm{y} \leq 25)$, and (3) abutments with long embankments $(\mathrm{L} / \mathrm{y}>25)$. For long embankments, the data suggest that the equilibrium-scour depth is less dependent of embankment length, and more dependent on the approach flow velocity and depth. This does not mean a long embankment has no effect on scour depth. Field data and laboratory data clearly show that deeper abutment-scour holes are associated with longer embankments. This only implies that at long embankments, the rate of change in abutment-scour depth as embankment length increases is diminished. For the 209 observations of abutment scour in South Carolina, model data show that $\mathrm{L}$ ranges from 18 to $7,440 \mathrm{ft}$ and y ranges from 1.3 to $20.5 \mathrm{ft}$. Applying Melville's classification to these sites, 2 abutments have short embankments, 47 have intermediate embankments, and 160 have long embankments. The Coastal Plain has 109 observations of abutment scour, of which 103 are clas- sified as long embankments. In contrast, there are 100 observations of abutment scour in the Piedmont of which 57 are classified as long embankments. If the observed data are representative of the bridge abutment population in South Carolina, then approximately 77 percent of all abutments would be classified as having long embankments and the rate of change in abutmentscour depth with increasing embankment length would be less pronounced. Figure 46 shows most field observations falling under the horizontal part of the envelope where the effects of embankment length on scour depth are diminished, giving support to this conclusion.

To provide some perspective on the relation of scour depth and embankment length for non-normalized field data, figure 47 shows plots of field data collected in the Coastal Plain and Piedmont of South Carolina. The envelope curves of these data show an increase of clear-water abutment-scour depth with increasing embankment length. In addition, the rate of change in abutment-scour depth diminishes as embankment length increases. Both of these trends are similar to laboratory data. Figure 48 compares the envelope 
A.

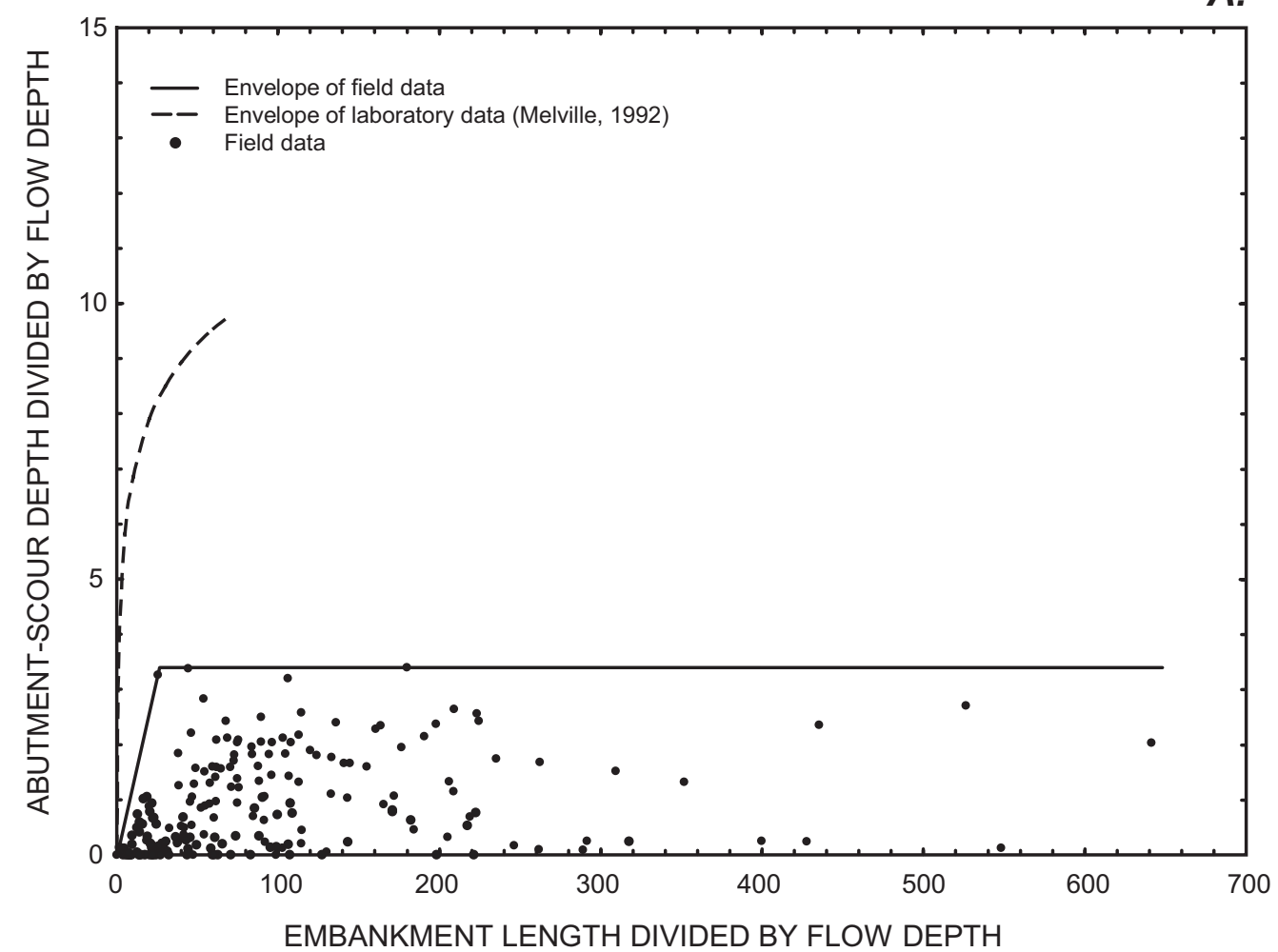

B.

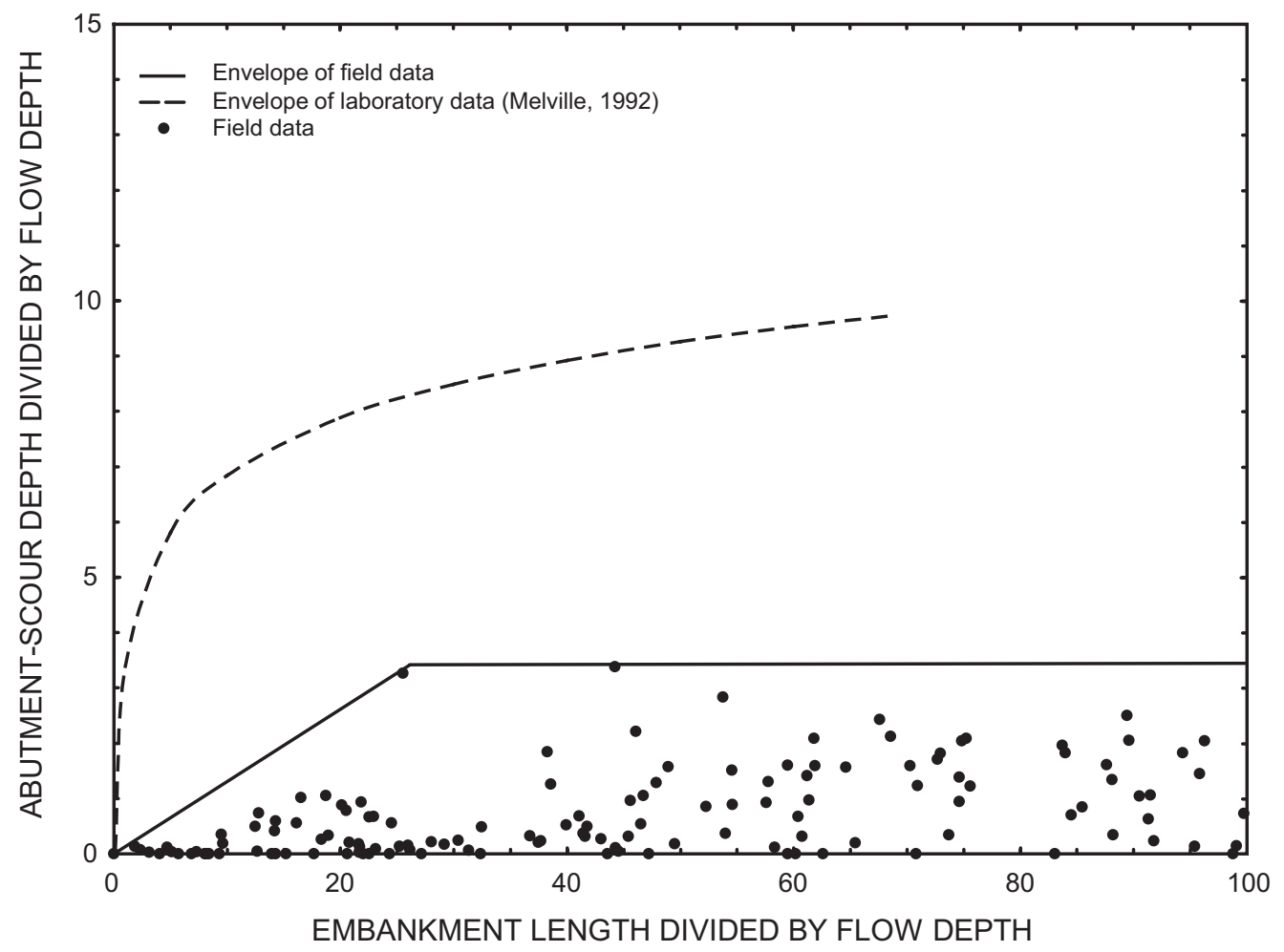

Figure 46. Relation of observed clear-water abutment-scour depth and the 100-year-flow embankment length, normalized by the 100-year-flow depth near the abutment toe, for the Piedmont and Coastal Plain of South Carolina with a $(A)$ complete horizontal axis, and a $(B)$ truncated horizontal axis. 
A.

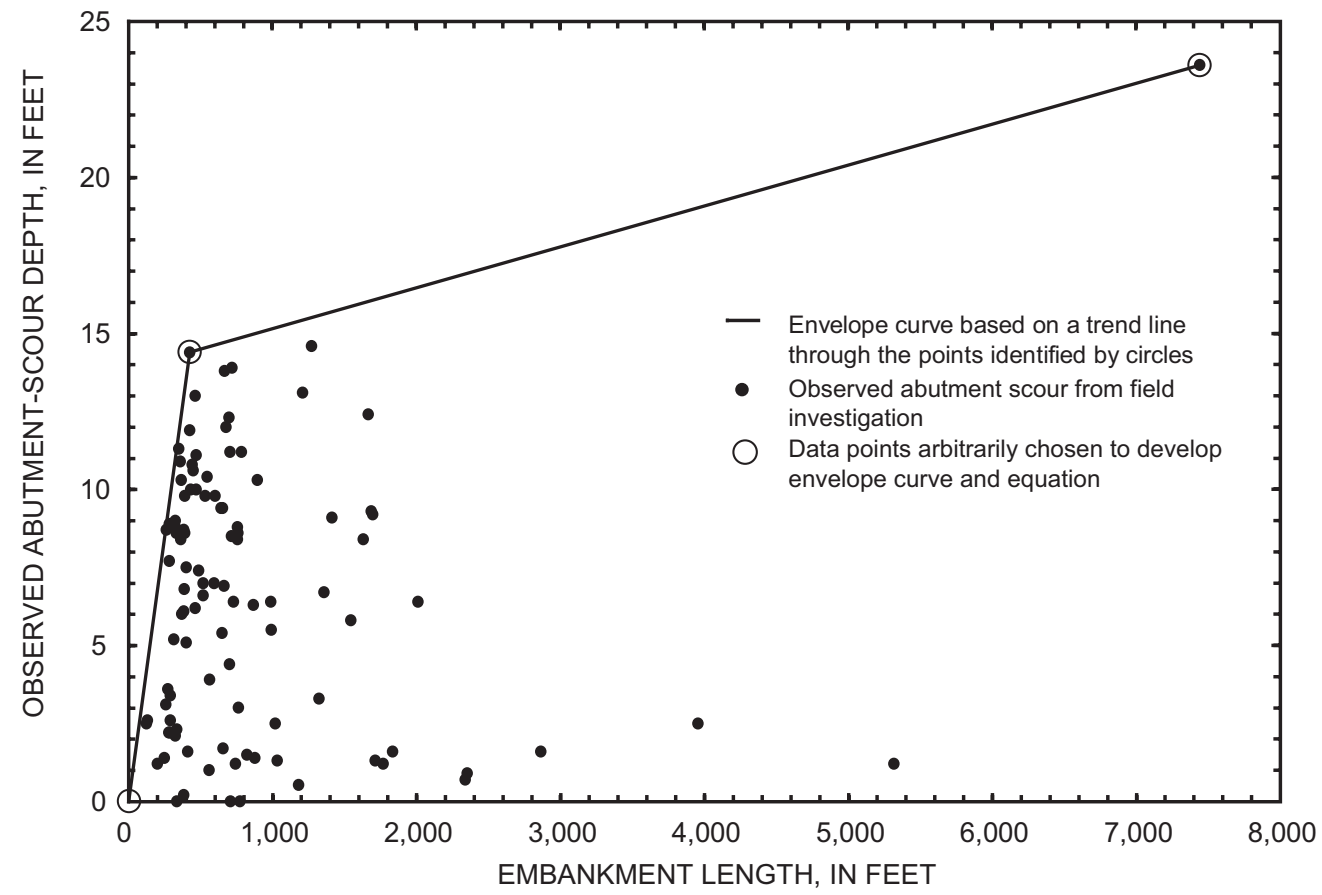

B.

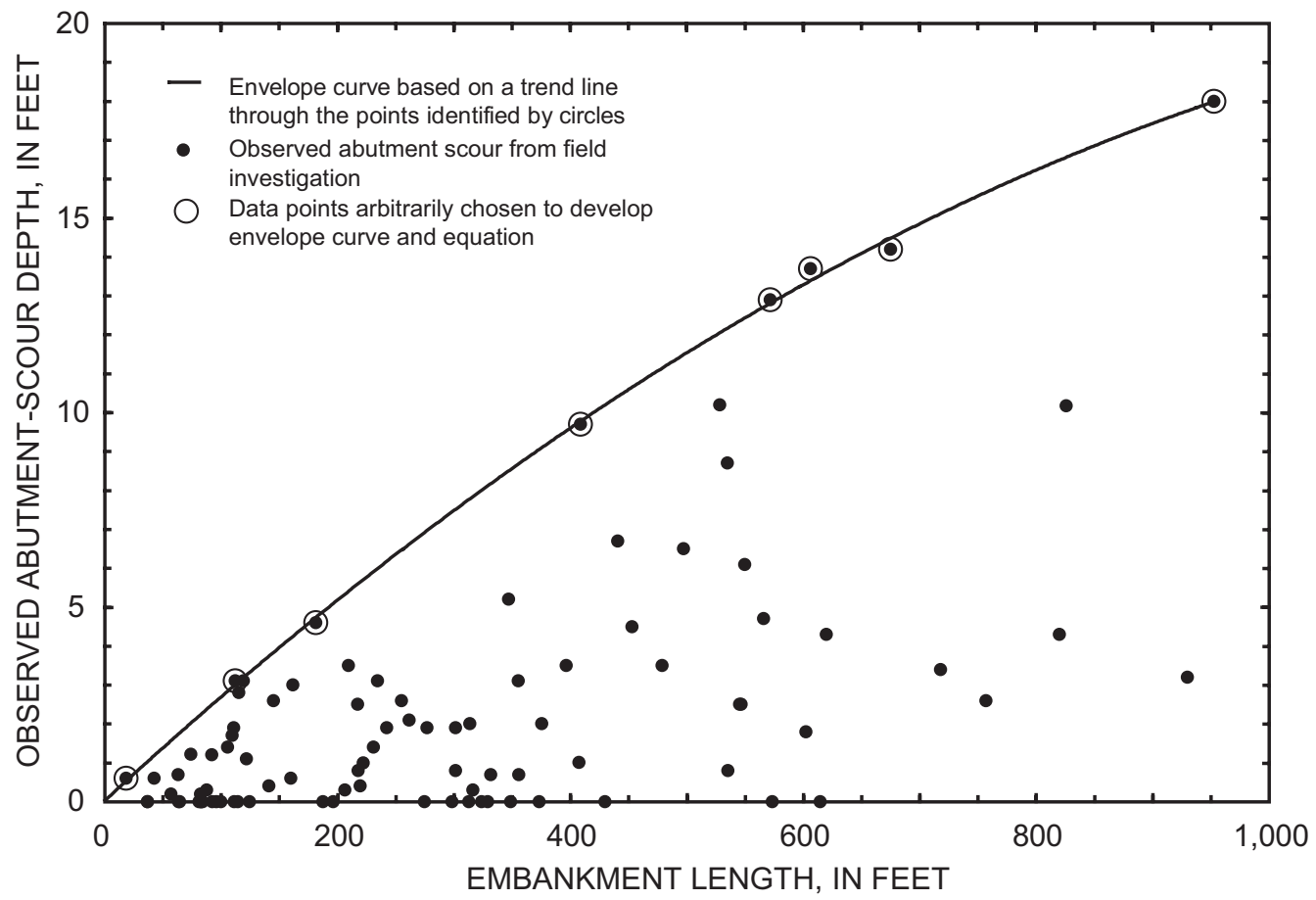

Figure 47. Relation of observed clear-water abutment-scour depth and the 100-year-flow embankment length for the (A) Coastal Plain and (B) Piedmont of South Carolina. 


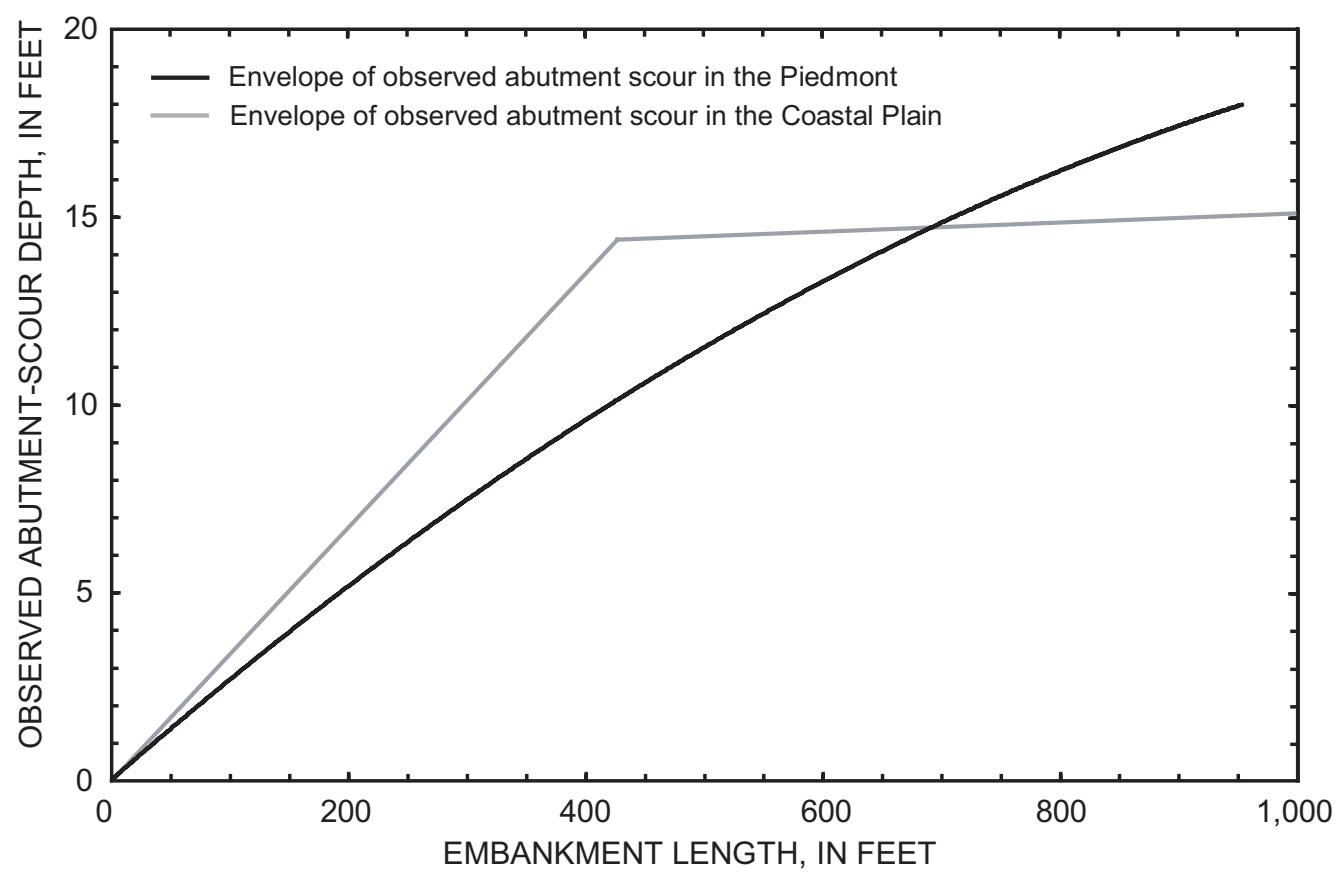

Figure 48. Comparisons of envelopes for observed clear-water abutment-scour depth and the 100-year-flow embankment length for the Piedmont and Coastal Plain of South Carolina.

curves between the Piedmont and Coastal Plain. Interestingly, the envelope curves are similar, with the Piedmont envelope being lower for embankment lengths less than $700 \mathrm{ft}$. This trend is consistent for the differing soils between the Piedmont and Coastal Plain. Because the envelope curves were developed using different data sets, the similarity between the curves gives some support that the envelope curves are showing anticipated trends. Such envelope curves can serve as tools for assessing clear-water abutment-scour depth; various envelope curves are discussed later in the report under "Abutment Scour in the Piedmont" and "Abutment Scour in the Coastal Plain."

\section{Abutment Shape}

Laboratory studies indicate that vertical abutments (fig. 32) create larger scour depths than wingwall and spill-through abutments (fig. 30). To account for this phenomenon, empirical abutment-scour equations often include a correction coefficient for shape, with vertical-wall abutments having a correction coeffi- cient of 1 and wing-wall and spill-through abutments having values less than 1. Melville (1992) suggests that as the embankment length increases, the benefits derived from wing-wall and spill-through abutments is diminished and will become negligible for long embankments. Melville's suggestion seems reasonable, and, if correct, would indicate that abutment shape has little influence on the equilibrium-scour depths for long embankments. Based on Melville's embankment length model, 77 percent of the bridges sampled in this study are classified as long embankments, indicating that abutment shape may have negligible influence on abutment-scour depths at many sites in South Carolina. This phenomenon will be more pronounced in the Coastal Plain where the percentage of long embankments is higher. With respect to the current study, all but 5 of 209 field observations of abutment scour were for spill-through abutments. Therefore, conclusions drawn from this study must, in general, be limited to bridges with spill-through abutments, and the influence of abutment shape cannot be verified with this data set. 


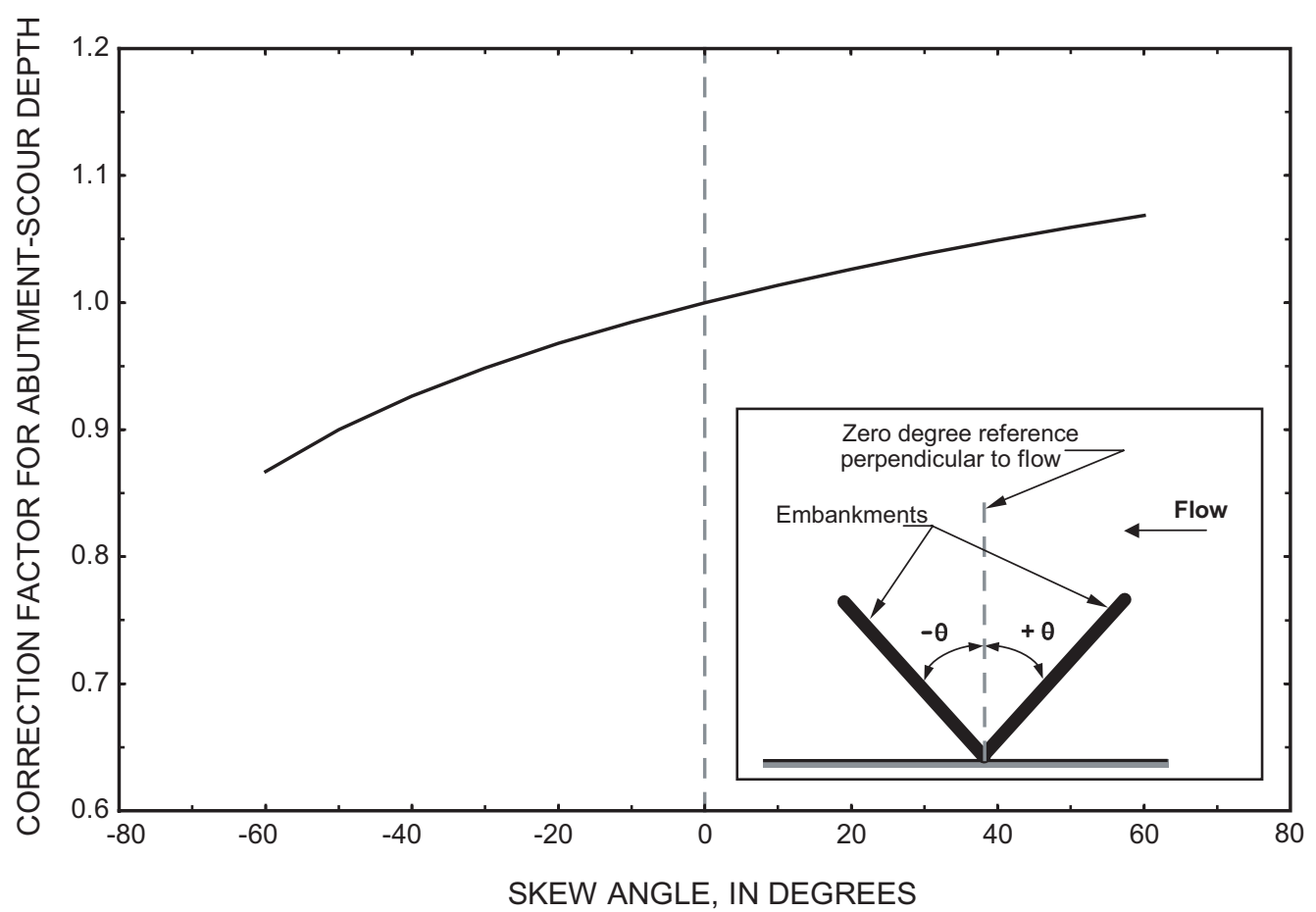

Figure 49. Relation of abutment-scour depth correction factor and embankment skew based on data obtained from laboratory investigations where experimental tests ran for 300 minutes or less. (Modified from Dongol, 1993.)

\section{Embankment Skew}

Laboratory investigations of the effects of embankment skew on scour depth have yielded contradictory results (Dongol, 1993). Early investigations indicated that embankments skewed upstream toward the approaching flow (defined as positive angles in this study) produced larger scour depths than its perpendicular counterpart. In contrast, embankments skewed downstream, away from the approaching flow (defined as negative angles in this study) produced smaller scour depths. Two later investigations (Kwan, 1984;

Kandasamy, 1985) contradicted these results and showed that embankments skewed upstream or downstream produced smaller scour depths than their perpendicular counterparts. Dongol (1993) suggests that a major reason for this contradiction is that the earlier studies were run for 300 minutes or less, providing insufficient time for the experiments to reach equilibrium-scour conditions. In contrast, the later studies were run for periods greater than 5,000 minutes providing adequate time to reach equilibrium conditions and in turn providing more reliable results. If these later observations are correct, then embankments with no skew are worst-case conditions for equilibrium-scour depth and skews on embankments would be considered beneficial.

Even if results from the older studies are considered reliable for assessing the effects of skew on abutment-scour depths, from a practical view, the effects are often minor. Using an envelope of the older laboratory data, Froehlich (1989) developed an equation to estimate an adjustment factor for the effects of skew. A modified form of the equation is $[(90+\theta) / 90]^{0.13}$, where $\theta$ is the embankment skew in degrees measured from a perpendicular reference to the flow (fig. 49), with upstream skews being positive and downstream skews being negative. Figure 49 shows a plot of this equation and as can be seen, even for severe cases of skew (60 degrees from perpendicular) the maximum increase in scour depth is about 7 percent. Of the 209 observations of abutment scour in the current study, 70 observations have absolute skew angles greater than 0 degrees, with 11 observations exceeding 20 degrees 


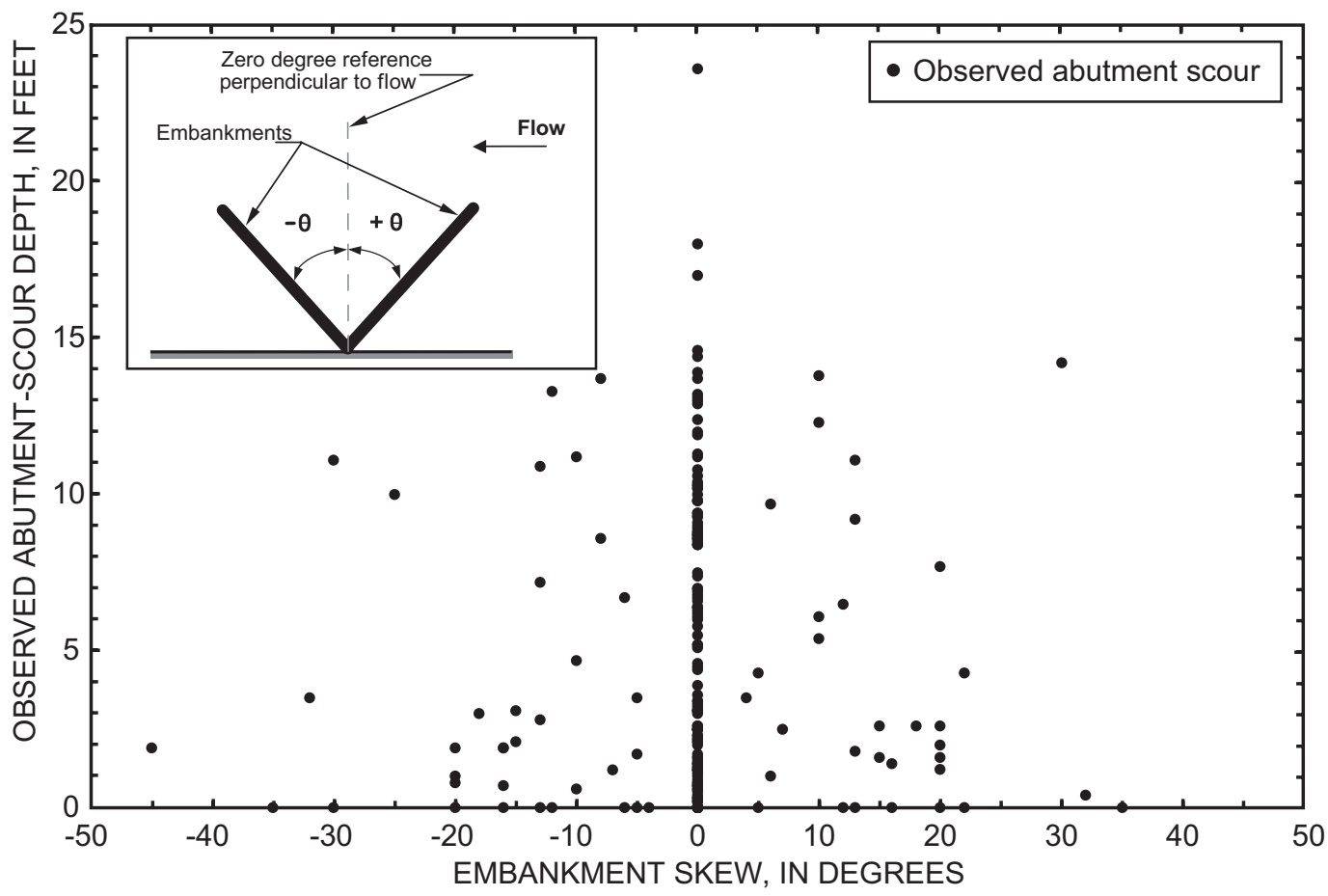

Figure 50. Relation of observed clear-water abutment-scour depth and embankment skew for selected sites with left and (or) right abutment scour in the Piedmont and Coastal Plain of South Carolina.

from perpendicular and the maximum skew being 45 degrees. With a skew of \pm 45 degrees, the correction to abutment-scour depth ranges from -9 to 6 percent depending on orientation to flow. For skews of \pm 20 degrees the correction factor ranges from -3 to 3 percent. If these corrections are applied to the largest abutment-scour depth observed in this study (23.6 ft), then the theoretical variation in scour depth for skews of \pm 45 degrees is -2.1 to $1.4 \mathrm{ft}$ and for \pm 20 degrees is -0.7 to $0.7 \mathrm{ft}$. For scour depths less than $23.6 \mathrm{ft}$, the magnitude of the corrections will be smaller. Because of the large scatter associated with field data and the complexities of field conditions in contrast to laboratory conditions, adjustments of this small magnitude cannot be identified within field data.

Initial reviews of the field data in this study do not indicate any major differences in scour depths between skewed and unskewed embankments. Investigating the effects of skew on abutment-scour depths is difficult to accomplish using field data because skewed and unskewed conditions at a given site cannot be compared. In addition, left and right embankment lengths at a skewed bridge are commonly different, making it difficult to draw any conclusions about the effect of negative and positive skews at that site. However, some broad observations can be made that may provide qualitative insights about the effect of skew. Figure 50 shows the relation of observed abutment-scour depth and embankment skew for the 209 observations of abutment scour in this study. Because influencing variables, such as embankment length and flow velocity, are not incorporated in this figure, the effect of skew cannot be readily assessed. The figure indicates that the range for abutment-scour depth (approximately 0 to $14 \mathrm{ft}$ ) at embankments with negative and positive skews does not exceed the range for unskewed ( 0 degrees) abutment-scour depths ( 0 to $23.6 \mathrm{ft}$ ). This observed trend in figure 50 does not define the effect of skew at a given abutment. It does, however, indicate that the upper limit for abutmentscour depths at skewed embankments will likely be within the range for unskewed embankments for sites similar to those investigated in this study. This suggests that skews similar to those found in this study will have minimal impact on scour depths. 


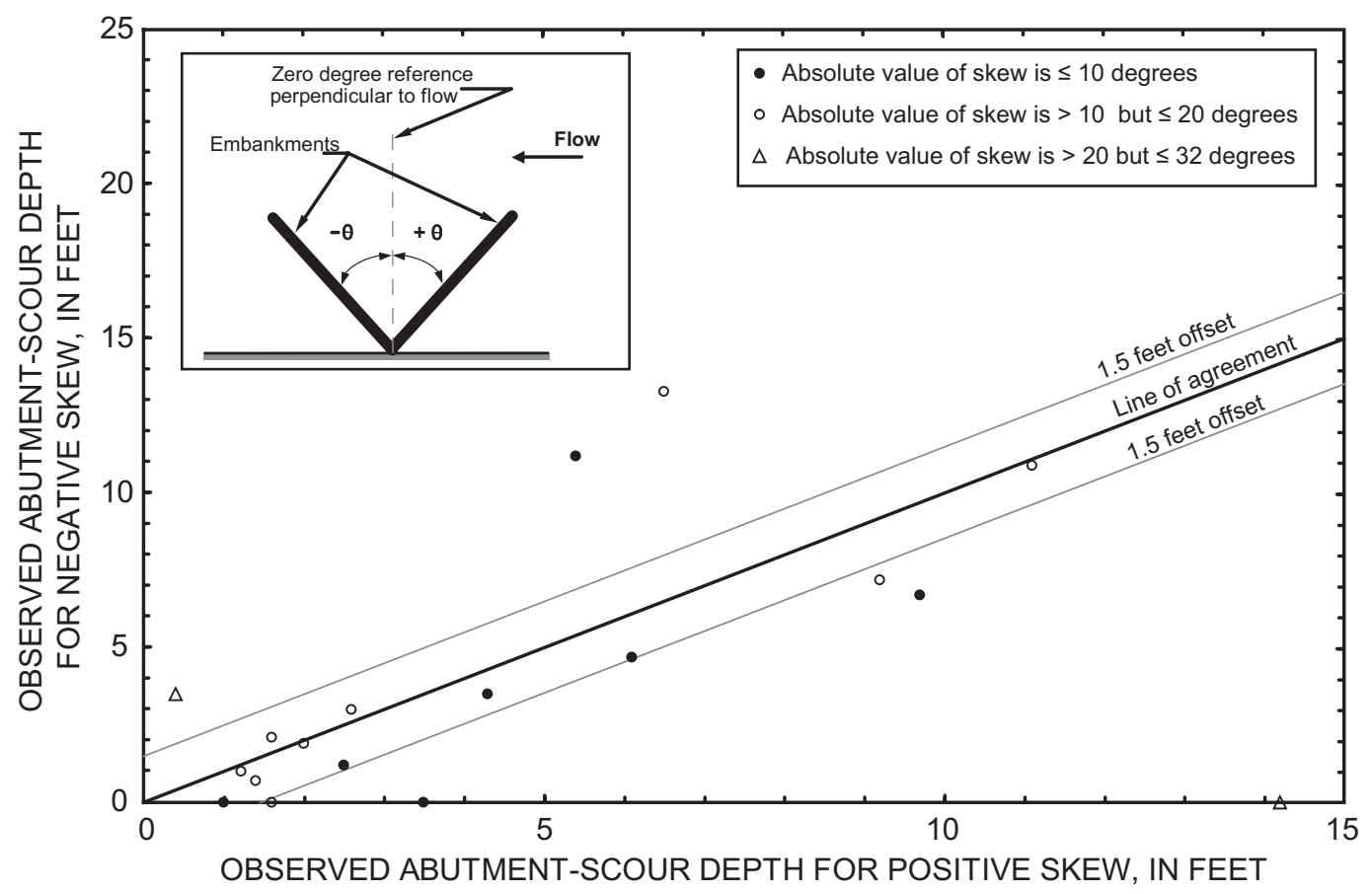

Figure 51. Relation of observed clear-water abutment-scour depth, for positive and negative skews, at sites with left and right abutment scour in the Piedmont and Coastal Plain of South Carolina.

The relation of abutment-scour depths for bridges having both negative and positive skews with observations of left and right abutment scour (18 sites) is shown in figure 51 . For a given skewed bridge, the left and right embankments will have the same absolute value of skew, with one of the embankment-skew values being positive and the other negative, depending on the orientation of the embankment to flow. Comparison of the left and right abutment-scour depths at a given site (based on the positive and negative skew) may provide some insight of the effect of skew on scour depth. If the trend in Froehlich's (1989) equation is correct, then negative values of skew should produce smaller scour depths in comparison with the complimentary abutment with the positive skew.

A weakness in the relation in figure 51 is that most sites have different left and right embankment lengths. For example, the left abutment at S.C. Route 201 crossing the Little River in Abbeville County (reference number 1, app. B) has an observed scour depth of $4.3 \mathrm{ft}$ associated with a 100 -year-flow embankment length of $620 \mathrm{ft}$ and an embankment skew of 5 degrees. In contrast, the right abutment at this site has an observed scour depth of $3.5 \mathrm{ft}$ associated with an embankment length of $479 \mathrm{ft}$ and an embankment skew of -5 degrees.

Because embankment length is an important explanatory variable for scour depth, the difference in left and right abutment-scour depths at this site may be more appropriately explained by embankment length rather than skew. To isolate the effect of skew, it would be best to have skewed bridges with equal left and right embankment lengths. However, sites with these conditions were observed infrequently in this study. For the sites shown in figure 51, the difference between the left and right embankment lengths at a given site ranges from 17 to $1,549 \mathrm{ft}$ with a median of $262 \mathrm{ft}$. This large range indicates that the relation in figure 51 likely does not isolate the effect of skew. Eleven of the sites in figure 51 have left and right abutment-scour depths that differ by $1.6 \mathrm{ft}$ or less. From a practical view, this difference is minimal. The seven remaining bridges, with differences greater than $1.6 \mathrm{ft}$, have site-specific conditions other than skew, that provide 
good explanation for the difference between left and right abutment-scour depths. These conditions include longer embankment lengths or significantly lower Manning's roughness coefficient at the deeper of the left and right scour holes, and site anomalies such as channel bends or multiple-bridge openings. The relation in figure 51 does not define the effect of skew on abutment-scour depths; however, it does appear to indicate that the effect of skew is probably minor.

\section{Channel Geometry}

Until recent years, much of the laboratory research on abutment scour has been made in simple rectangular flumes with minimal attention given to the effects of irregular shaped channels that are typically found in the field. Natural rivers commonly have compound channels that consist of a main channel and floodplain with variations in Manning's roughness coefficients. The cross-section geometry and roughness changes associated with compound channels create flow distributions that can be significantly different from the uniform flow patterns of simple rectangular channels. In general, compound channels will tend to reduce abutment-scour depths in comparison to rectangular channels. Richardson and Richardson (1992, as cited in Richardson and Davis, 1995) have argued that this is a major cause for the overprediction of scour depths by laboratory-derived equations. Laboratory data suggest that reduction in scour depths will be most noticeable at embankments projecting into the main channel (fig. 52) and abutments set at the channel bank. Laboratory investigations of this type of abutment indicate that scour depths can be reduced by as much as 40 percent from scour depths in simple rectangular channels (Dongol, 1993). However, when abutments are removed from the channel and set back some distance from the channel bank (fig. 53), laboratory data suggest that the effect of channel geometry is diminished and likely becomes negligible (Melville and Coleman, 2000). Under such conditions it is reasonable to isolate the floodplain as a separate channel and assume the main channel has no influence on abutment-scour depth. This is the general procedure recommended in HEC-18 (Richardson and Davis, 1995).

With regard to the influence of channel geometry on abutment scour in South Carolina, several observations can be made. In general, the swampy low-flow channels of the Coastal Plain are narrow and shallow and convey only a small percentage of the total flood flow.
In many cases, these channels are almost indistinguishable from the floodplain. In addition, the Manning's roughness coefficient is typically uniform across the floodplain creating a relatively uniform flow distribution. An example of a Coastal Plain cross section is shown on figure 54. The shape and flow distributions associated with a swampy cross section approximate flow conditions in a simple rectangular flume. At swampy Coastal Plain sites, the effect of irregular channel geometry is expected to be minor. In contrast, the channel geometry of the Piedmont streams includes a low-flow channel that often carries a large part of the total flood flow (fig. 55). All study sites in the Piedmont had setback abutments where embankments block only floodplain flows. Piedmont floodplains are generally rectangular in shape with uniform boundary roughness. Laboratory investigations of setback abutments in compound channels having rectangular floodplains with uniform floodplain roughness indicate that the effect of channel geometry on scour depths is minimal. Therefore, it is likely that the effect of channel geometry on setback abutments in the Piedmont is minimal as well.

\section{Geometric-Contraction Ratio}

Although the geometric-contraction ratio $(\mathrm{m})$ is not directly mentioned in Dongol's (1993) list of influencing variables, the dimensionless ratio is directly related to embankment length and channel width, and is defined as $m=1-b / B$, where $B$ is the approach flow width in feet and $\mathrm{b}$ is the bridge-opening width in feet. The geometric-contraction ratio is an indicator of the severity of flow contraction created by a bridge and with an increase in this ratio, it would be reasonable to anticipate larger scour depths. Das (1973) identified the geometric-contraction ratio as an important explanatory variable for abutment scour and showed that abutment-scour depth increases with increasing geometriccontraction ratio (fig. 56). A similar trend is evident in the envelope of the South Carolina field data (fig. 57). Even though the vertical scales in the figures have not been made dimensionless, the shapes of the envelope curves are similar, indicating that the field data in South Carolina display similar trends to laboratory data. Envelope curves like that shown in figure 57 can serve as tools for assessing clear-water abutment scour. Several envelope curves are discussed later in this report under "Abutment Scour in the Piedmont" and "Abutment Scour in the Coastal Plain." 


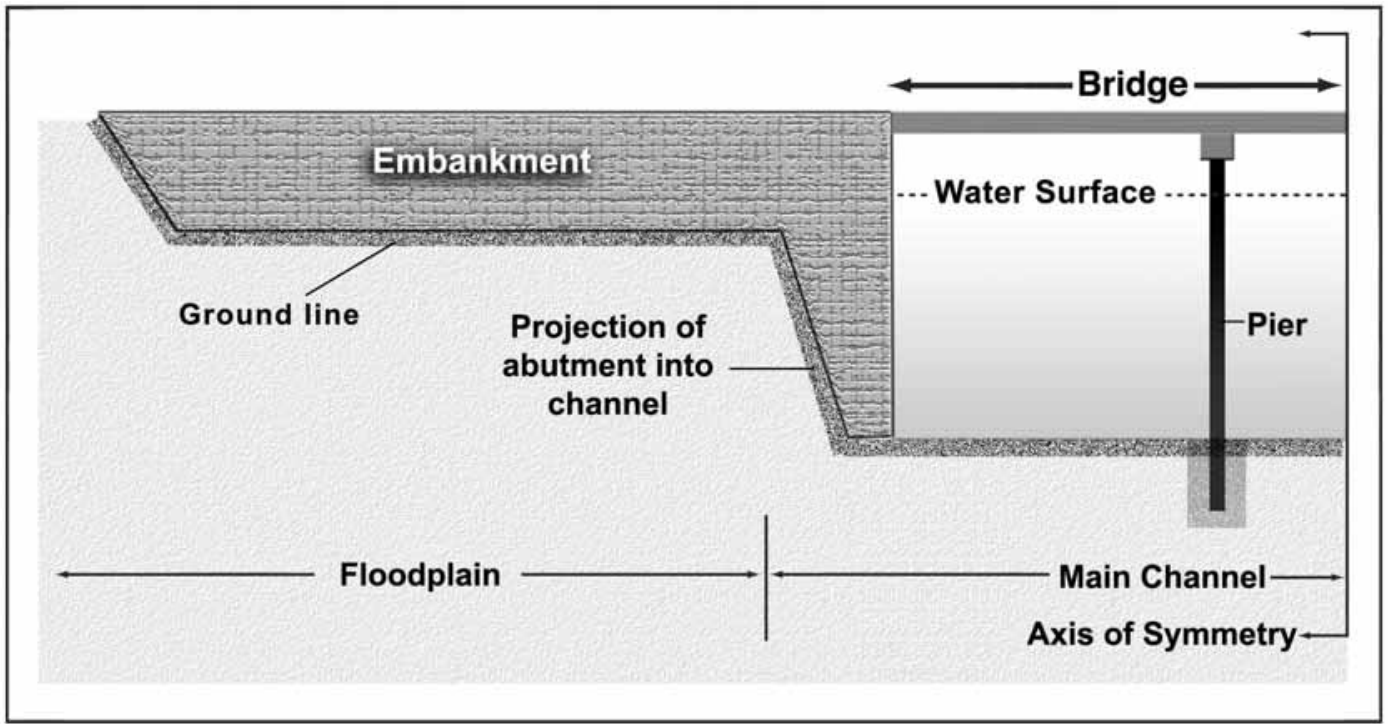

Figure 52. Profile of abutment projecting into main channel.

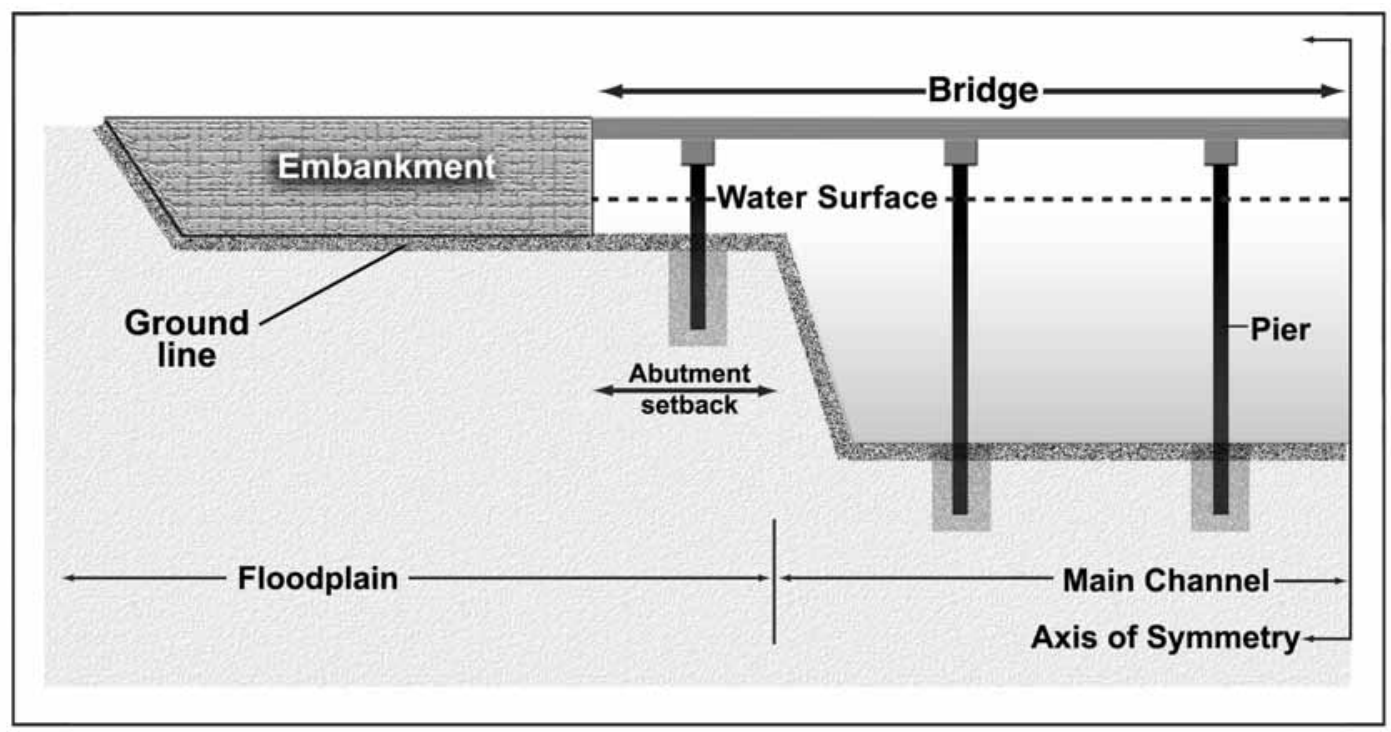

Figure 53. Profile of setback abutment commonly found in the Piedmont of South Carolina.

\section{Conclusions}

The review of variables that influence abutment scour in laboratory investigations indicates that many of these variables likely have minimal influence on abutment-scour depths for the prevailing field conditions in South Carolina. The variables that appear to have minimal influence include flow duration, flow depth, sediment size, sediment gradation, abutment shape, abutment skew, and channel geometry. The variables that have the most significant effect on abutment-scour depth appear to be embankment length, geometric-contraction ratio, flow velocity, and soil cohesion. Many of the fielddata relations reviewed in this report were developed from modeled rather than measured hydraulics and all of the relations clearly show a large scatter. With these limitations in mind, conclusions drawn from the field-data relations should be viewed with caution. It is important to realize that variables that appear to have minimal effect within the South Carolina data may be important explanatory variables for abutment scour in regions that have field conditions that deviate from those in South Carolina. 


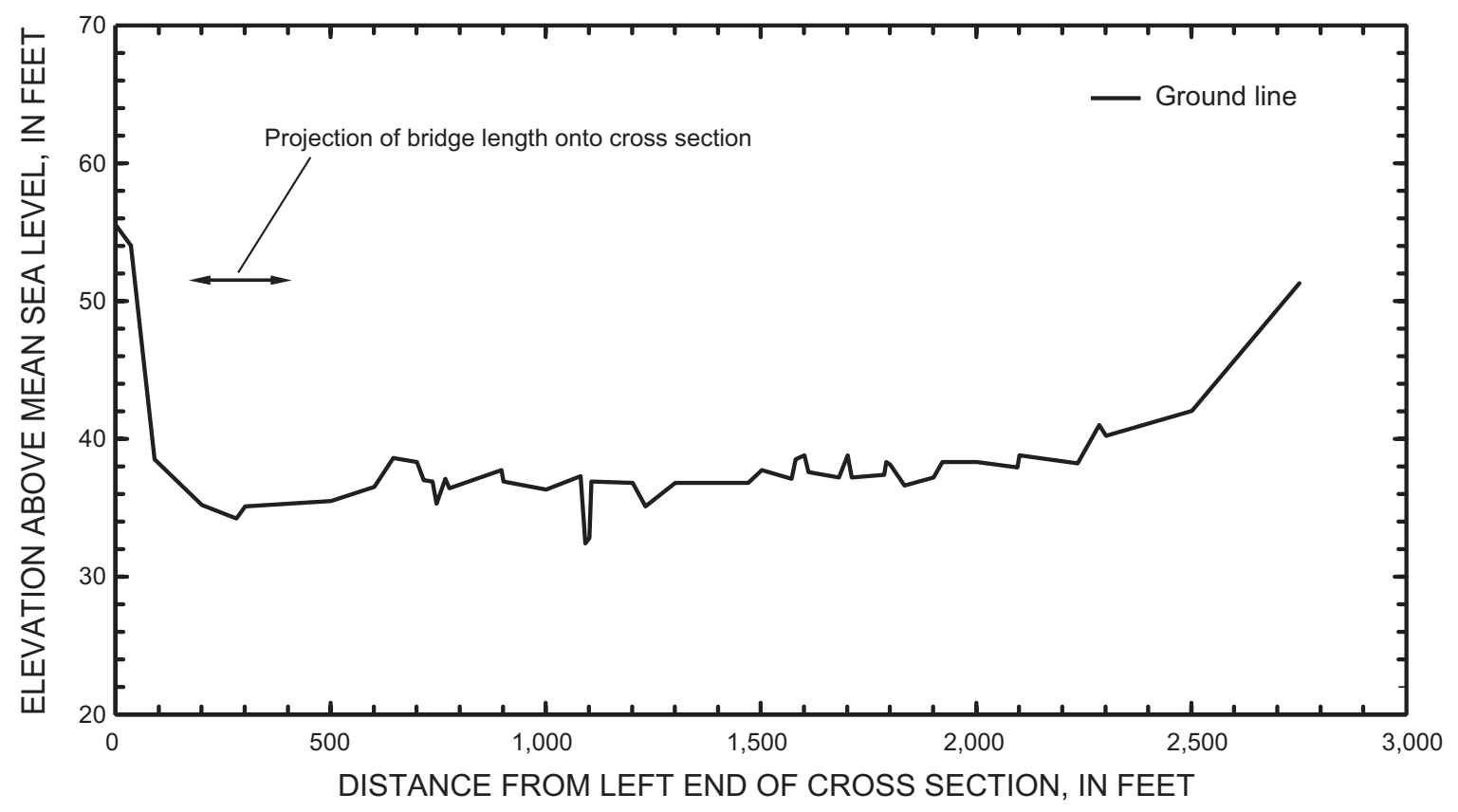

Figure 54. Example of Coastal Plain natural cross section at Structure 212037801000 on U.S. Route 378, crossing Big Swamp in Florence County, South Carolina. (Data from the South Carolina Department of Transportation road plans, File Number 21.253, dated 1947.)

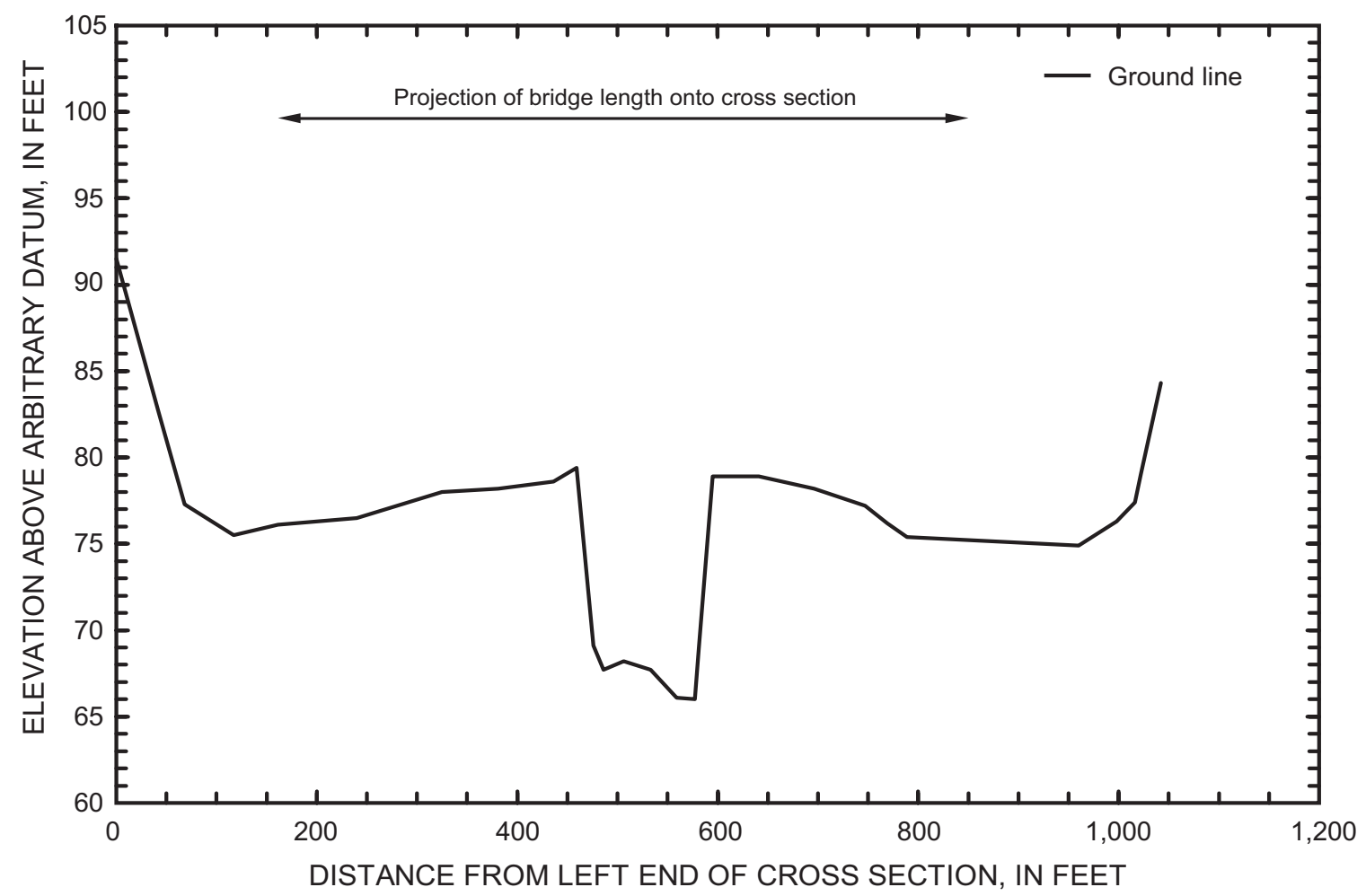

Figure 55. Example of Piedmont natural cross section at Structure 444005600100 on S.C. Route 56, crossing the Enoree River in Union County, South Carolina. (Data from field survey by the U.S. Geological Survey, 1998.) 


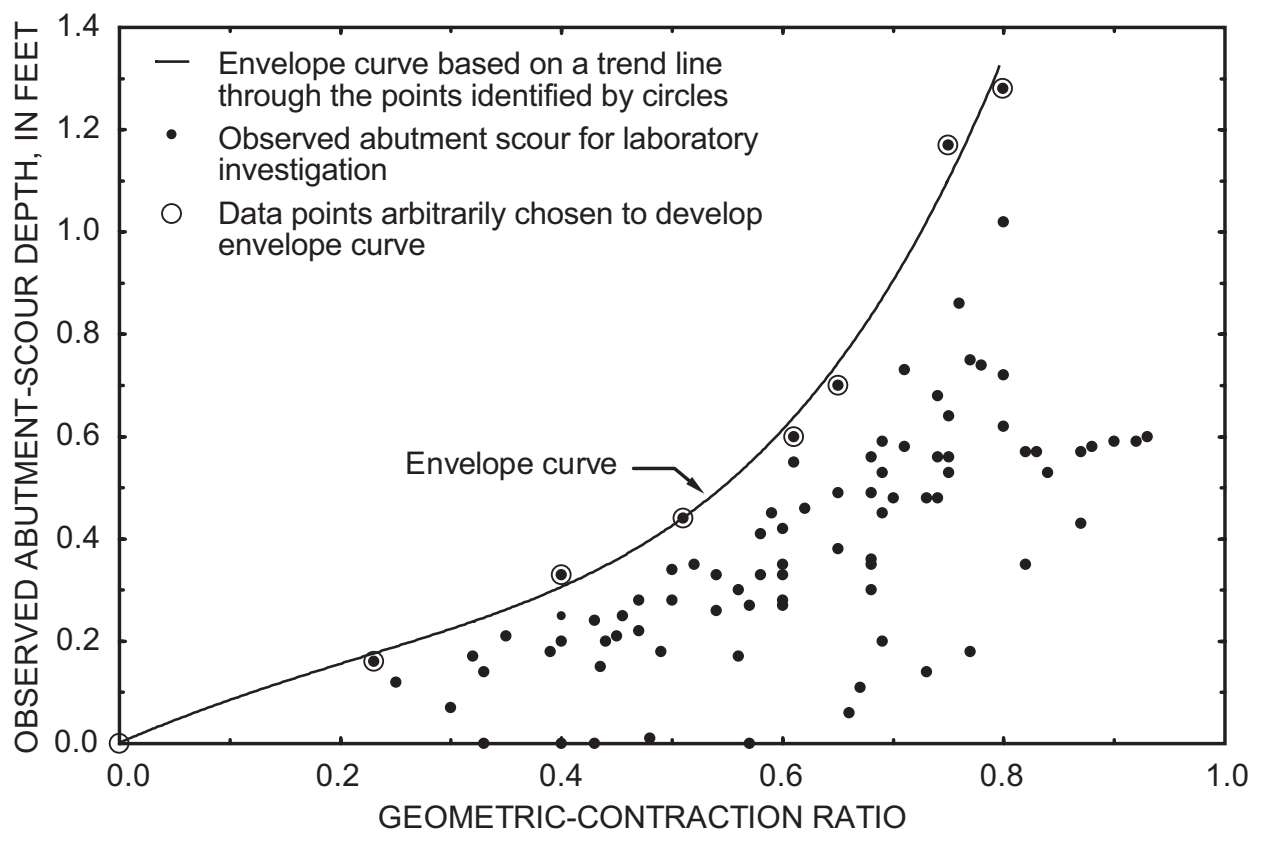

Figure 56. Relation of abutment-scour depth and geometric-contraction ratio for laboratory data. (Das, 1973.)

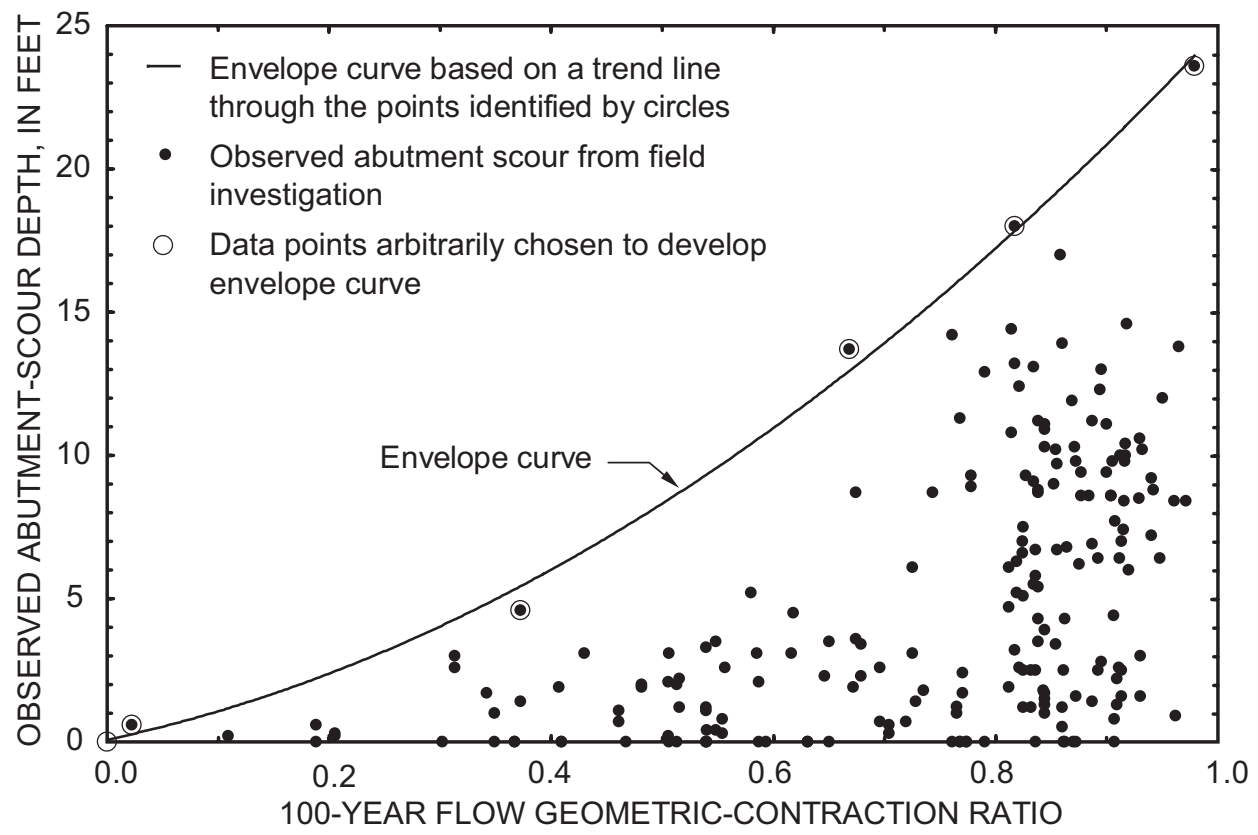

Figure 57. Relation of observed clear-water abutment-scour depth and the 100-year-flow geometric-contraction ratio in the Coastal Plain and Piedmont of South Carolina. 
The envelope relations of approach velocity and abutment-scour depth (fig. 40) are helpful in understanding the effect of approach velocity on abutmentscour depths. However, the envelope curves are limited to broad categories of embankment lengths, and the modeled velocities for the 100-year flow likely do not represent historic flow velocities that created the scour. Because of these limitations, the approach velocity and scour depth envelope relation in these figures are not recommended as primary tools for assessing scour in South Carolina.

When comparing the Piedmont and Coastal Plain envelope curves for the relation of approach velocity and scour depth (fig. 41), the scour depths in the Piedmont are significantly lower. This difference highlights the scour resistant nature of the cohesive Piedmont soils in contrast to the sandier soils of the Coastal Plain. Data collected in this study are insufficient to quantify the varying degrees of cohesion that exist within the soils of South Carolina. Only the broad categories of abutment scour in the Piedmont and the Coastal Plain can be used to, in some measure, incorporate the effect of varying soil cohesion.

Embankment length appears to be the strongest explanatory variable for abutment-scour depth in South Carolina. Although embankment lengths in this study were estimated with the WSPRO model using the 100year flow, these lengths (at a given site) are approximately constant for a large range of flood elevations and the estimates likely represent historic embankment lengths that created the scour. Embankment length can be estimated from topographic maps, road plans, or hydraulic models. The strong relation of embankment length within the field data, as well as the ease of estimating this parameter, makes embankment length a good explanatory variable for assessing abutment-scour depth in South Carolina. Tools for assessing abutment scour in South Carolina, as discussed in the following report sections, focus on envelope curves for the Piedmont and Coastal Plain regions developed with embankment length. Envelope curves developed with the geometric-contraction ratio also are discussed. In addition to $\mathrm{mi}^{2}$ (fig. 3) (Shearman, 1990). envelope curves for assessing potential abutment-scour depth, tools for assessing the location and width of abutment-scour holes are described.

A regression analysis of observed abutmentscour depth and selected explanatory variables indicated a weak correlation within the data and a large scatter of the observed data around the regression. From these results, it was concluded that envelope curves of the field data with selected explanatory variables would provide more reliable estimates of maximum observed scour depths than regression equations. Therefore, focus was given to developing these envelope curves for assessing scour in South Carolina.

\section{ABUTMENT SCOUR IN THE PIEDMONT}

One hundred observations of clear-water abutment scour were collected at 65 bridge sites in the Piedmont Province, including 21 bridges (table 2) influenced by the high-flow region (fig. 1) (Guimaraes and Bohman, 1992). The abutment configuration at all sites is a setback abutment where the toe of the abutment is located on the floodplain at some distance away from the main channel (fig. 53). With only two exceptions, all abutments were spill through (fig. 30). Table 10 lists the range for selected parameters associated with the 100 abutment-scour observations. Values for hydraulic data were estimated with the WSPRO model (Shearman, 1990) using the 100-year flow.

Table 10. Range of selected parameters for 100 observations of clear-water abutment scour collected at 65 bridges in the Piedmont of South Carolina $\left[\mathrm{mi}^{2}\right.$, square mile; $\mathrm{ft} / \mathrm{ft}$, feet per foot; $\mathrm{ft} / \mathrm{s}$, feet per second; $\mathrm{ft}$, feet; $\mathrm{mm}$, millimeter; <, less than]

\begin{tabular}{|c|c|c|c|}
\hline Parameter & $\begin{array}{l}\text { Minimum } \\
\text { value }\end{array}$ & $\begin{array}{l}\text { Median } \\
\text { value }\end{array}$ & $\begin{array}{l}\text { Maximum } \\
\text { value }\end{array}$ \\
\hline Drainage area $\left(\mathrm{mi}^{2}\right)$ & 11.0 & 74.9 & ${ }^{\mathrm{a}} 1,620$ \\
\hline $\begin{array}{l}\text { Channel slope determined from topographic } \\
\text { map (ft/ft) }\end{array}$ & 0.00015 & 0.0012 & 0.0029 \\
\hline $\begin{array}{l}\text { 100-year average approach velocity obstructed by } \\
\text { embankment }(\mathrm{ft} / \mathrm{s})^{\text {b }}\end{array}$ & 0.1 & 0.85 & 3.2 \\
\hline $\begin{array}{l}\text { 100-year average approach depth obstructed by } \\
\text { embankment (ft) }\end{array}$ & 1.0 & 5.4 & 14.6 \\
\hline Embankment length based on 100-year flow (ft) ${ }^{b}$ & 18.0 & 276 & ${ }^{c} 953$ \\
\hline Median grain size $(\mathrm{mm})$ & $<0.062$ & 0.073 & 0.990 \\
\hline Observed abutment-scour depth (ft) & 0 & 1.3 & 18 \\
\hline
\end{tabular}

${ }^{a}$ Approximately 97 percent of the study sites in the Piedmont have drainage areas less than 400

b Parameter was estimated from the one-dimensional water-surface profile model, WSPRO

${ }^{c}$ Three observations had embankment lengths exceeding $950 \mathrm{ft}$ and were significantly outside the range for the majority of the Piedmont data. These sites were excluded from development of the embankment-length envelope curve. Therefore, the range of Piedmont embankment lengths used in this study should be limited to $950 \mathrm{ft}$. 


\section{Comparison of Observed and Theoretical Abutment-Scour Depths}

To estimate theoretical abutment-scour depth for clear-water scour conditions, Hydraulic Engineering Circular Number 18 (HEC-18) (Richardson and Davis, 1995) recommends the use of Froehlich's (1989) equation (eq. 9) that was derived from laboratory data for noncohesive sediments. Because Piedmont soils typically have some degree of cohesion, the equation often gives excessive scour depths for this region. Figure 58A compares the theoretical abutment-scour depth computed for the 100-year flow with the observed abutment-scour depth and clearly shows the excessive
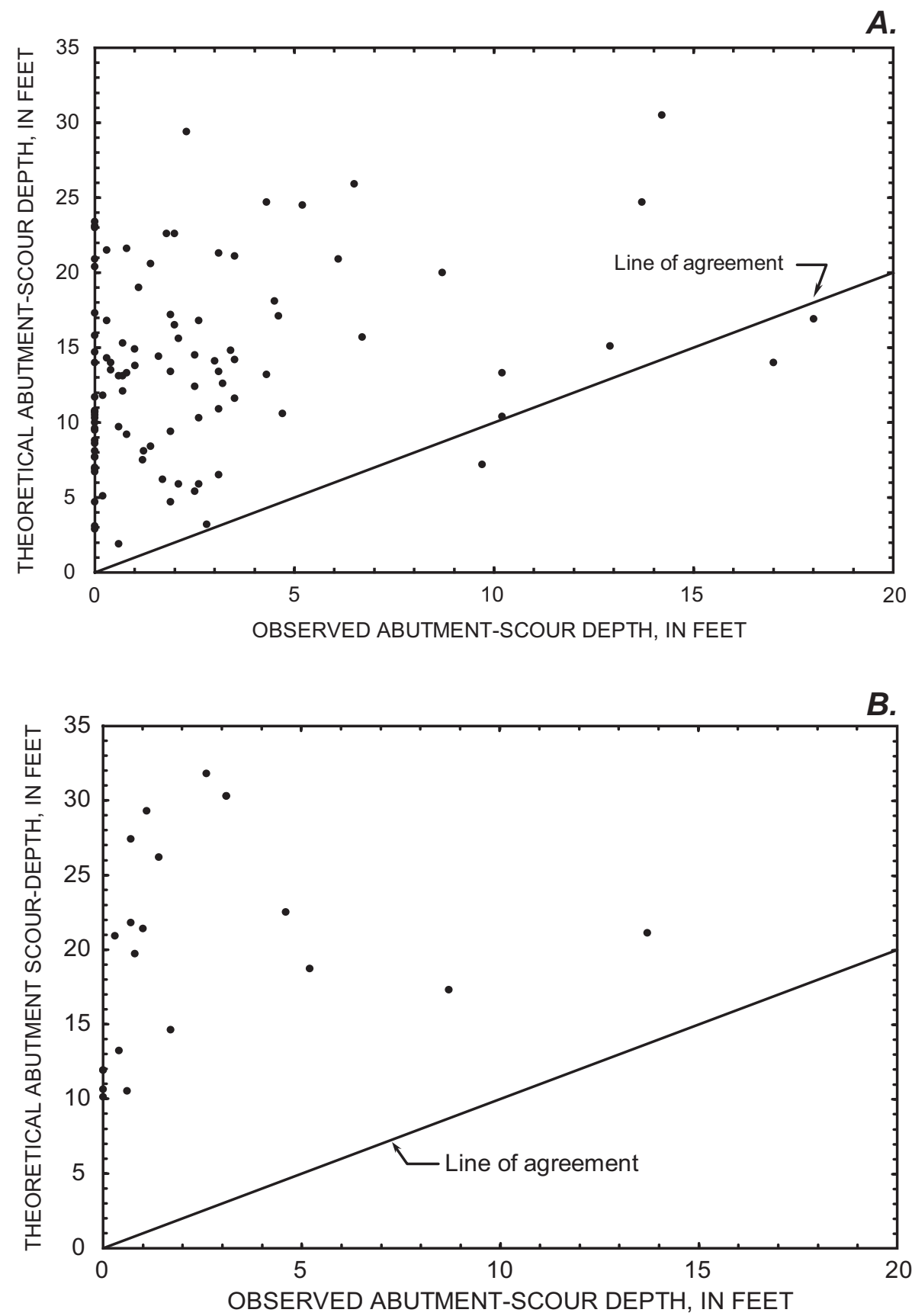

Figure 58. Relation of observed clear-water abutment-scour depth and theoretical abutment-scour depth for the (A) 100-year flow, and the (B) August 1995 flood at selected sites in the Piedmont of South Carolina. (Theoretical abutment scour calculated with the Froehlich (1989) equation.) 
scour depths given by Froehlich's equation for Piedmont soils. Only three observations of abutment scour are under predicted by the Froehlich equation with the largest underprediction being $3 \mathrm{ft}$; each of these sites has conditions that may explain this underprediction. One site is a multiple bridge opening where complex flow patterns may be improperly estimated by the onedimensional WSPRO (Shearman, 1990) model. At the other two sites, it is possible that the floodplain roughness coefficients in the WSPRO model were set too high for the conditions that may have created the scour. These sites were modeled for existing conditions at the time of the site visit. However, evidence indicates that floodplains at these sites were clear in years past, which would significantly lower the roughness coefficients and increase the theoretical scour depth computed by the Froehlich equation.

It should be kept in mind that the flows that created the observed abutment-scour depths are unknown for most sites plotted in figure 58A. The discrepancy between the observed and theoretical scour depths could be attributed to historic flows at these sites being less than the 100-year flow magnitude. Maximum historic flows have been documented at 12 sites along the Reedy, South Tyger and Enoree Rivers (table 6, fig. 6). Flows at these 12 sites occurred during the August 1995 flood, and 8 sites experienced flows exceeding the 100-year flow magnitude. A comparison of the theoretical abutment-scour depths, computed using the August 1995 flow magnitudes, with the observed scour still indicates excessive scour depths given by Froehlich's equation (fig. 58B). The results of figure 58A are based on the hypothetical 100-year flow, whereas figure 58B represents observed and theoretical scour for known maximum historic flows. Therefore, the results shown in figure 58B likely provide a better indicator of how well the Froehlich equation predicts theoretical scour. Regardless, both figures show a large discrepancy between observed and theoretical scour depths, suggesting that the Froehlich equation is a poor predictor for abutment scour at Piedmont sites and that another method is needed to estimate abutment scour in this region.

\section{Piedmont Floodplain Geometry as an Indicator of Potential Scour}

Because of the common occurrence of the scourresistant clayey soils in the Piedmont, deep abutmentscour holes were not anticipated to be found in this region. During initial reconnaissance in the Piedmont, however, several bridges with deep abutment-scour holes were discovered. The soils at these sites appeared to have more sand content or were more saturated than the clayey soils typically associated with the Piedmont. These conditions apparently made the soils more susceptible to scour and played a role in the development of the larger scour depths. An additional factor, however, could be the floodplain geometry consisting of wide, flat floodplains. Because of the rolling topography of the Piedmont, the stream network is fairly dense with numerous smaller streams combining to form larger streams. The smaller streams typically have narrow river valleys, and bridge crossings tend to make less severe contractions of flow. In general, large abutment-scour depths are not observed at such sites. In contrast, some of the larger streams have alternating reaches of narrow and wide river valleys (fig. 59).

When a bridge crossing occurs at the wider section of the river valley, the potential for abutment scour can be significantly increased because the bridge has more potential to create a large contraction of flow. Strictly speaking, the wide river valley is not the cause of deep abutment scour, but serves as an indicator for the potential of a large contraction of flow. If the wide river valley is associated with a bridge that creates a large contraction of flow and with scour-susceptible soils, then large abutment-scour depths can be anticipated. As shown on figure 59, the wide river valleys of the Piedmont are prominent features that can be easily identified on USGS 7.5-minute series topographic maps. Therefore, topographic maps can be useful tools in identifying bridges crossing wide river valleys and having a high potential for abutment scour.

\section{Embankment Length as an Indicator of Potential Scour}

In this study, the embankment length is defined for a given flow, by projecting the bridge section onto the approach cross section and determining the top width of the obstructed-flow area for the embankment of interest (fig. 33). Laboratory studies indicate that scour depth increases with increasing embankment length and logarithmically approaches a limit for longer embankments (fig. 45). The relation of the observed abutment-scour depths in the Piedmont and the embankment length for the 100-year flow shows similar trends to laboratory data (fig. 60). The envelope curve for observed data in the Piedmont clearly indicates that larger abutment-scour depths are associated with 

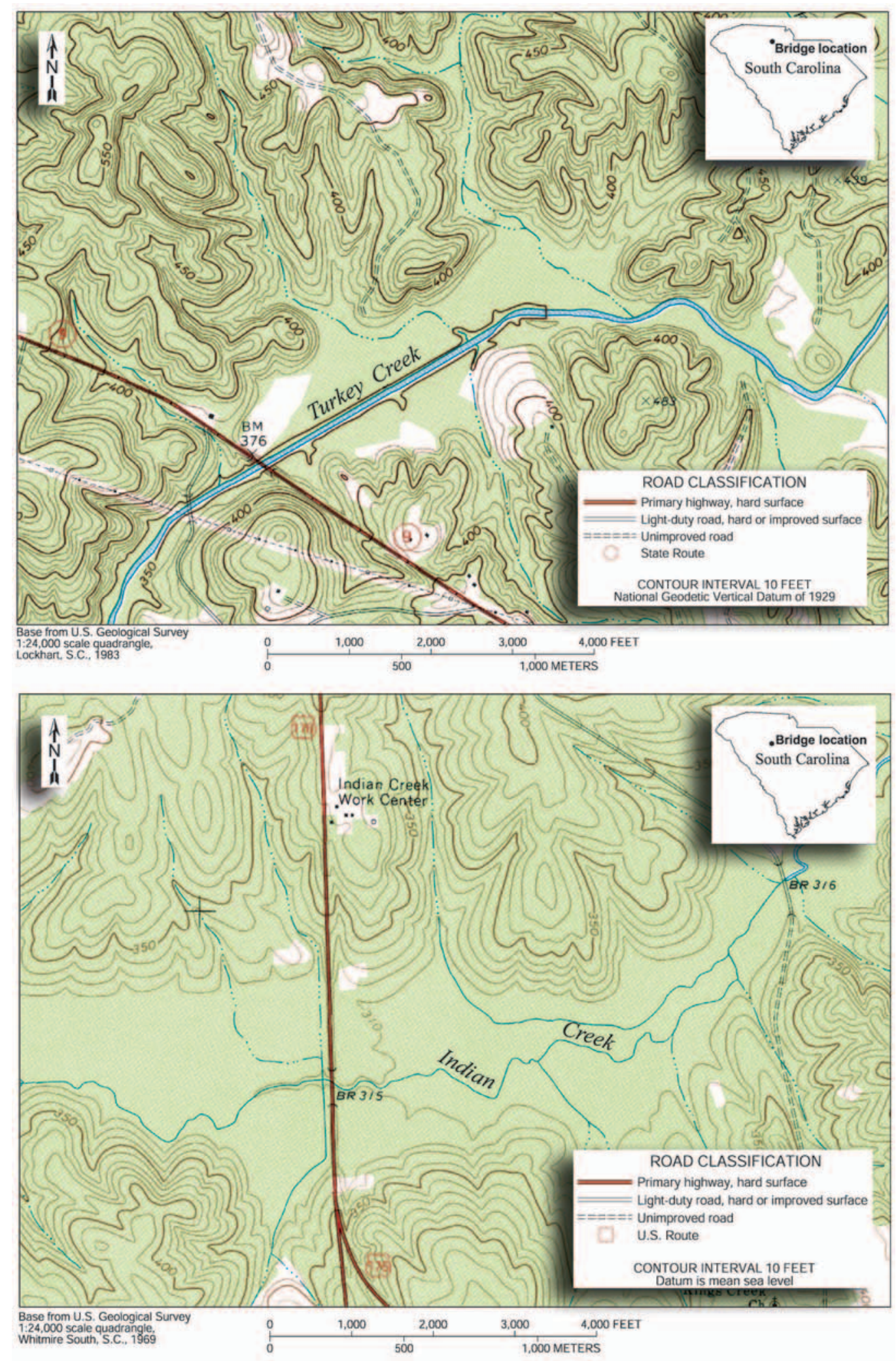

Figure 59. Example of wide, flat floodplain at (A) Structure 124000901100 on S.C. Route 9, crossing Turkey Creek in Chester County, South Carolina, and (B) Structure 362017600400 on U.S. Route 176, crossing Indian Creek in Newberry County, South Carolina. 


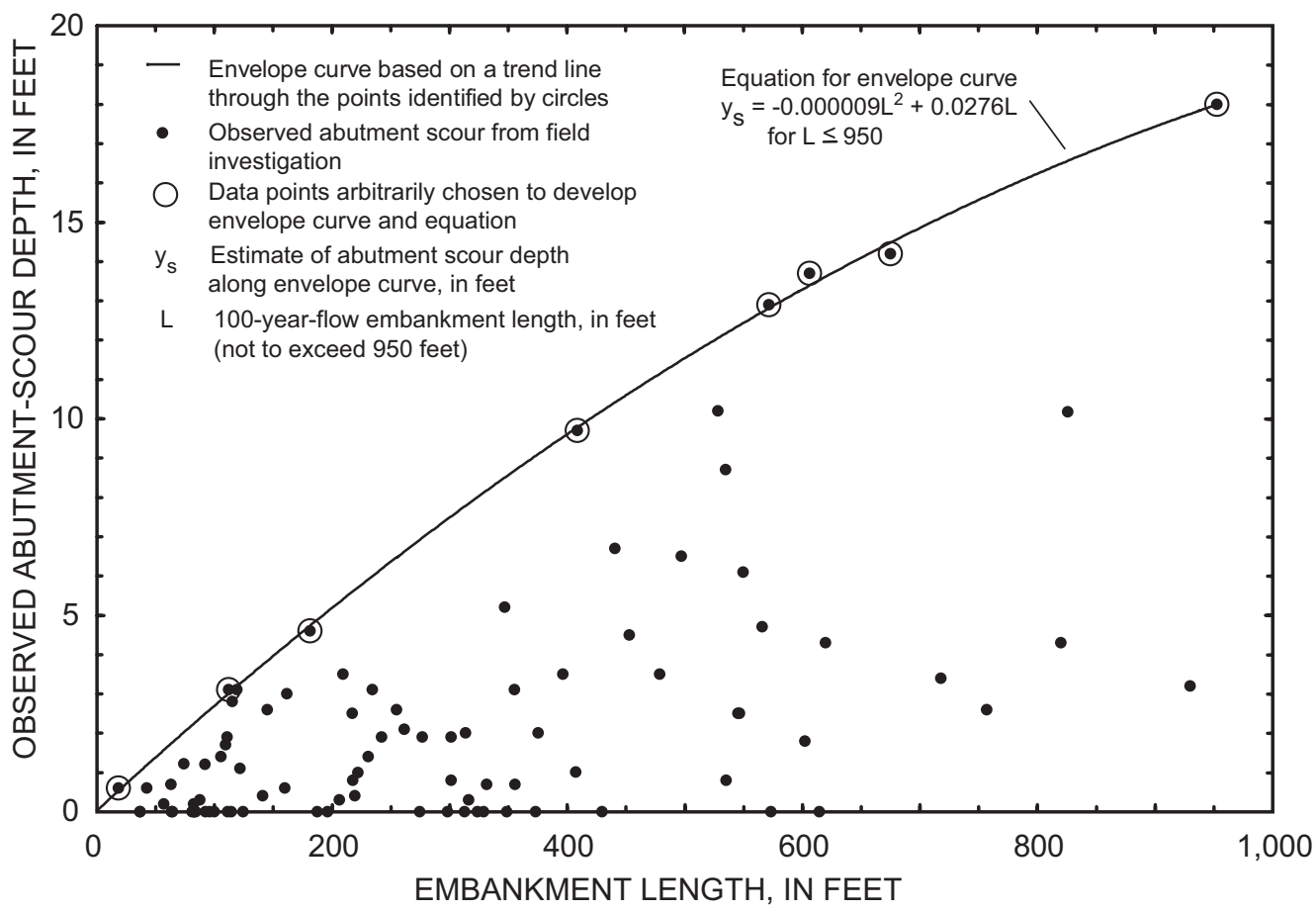

Figure 60. Relation of observed clear-water abutment-scour depth and the 100-year-flow embankment length in the Piedmont of South Carolina.

longer embankment lengths. As with the laboratory data, the influence of embankment length diminishes with increasing length and appears to be approaching a limit. An equation for this envelope is:

$$
y_{S}=-0.000009 L^{2}+0.0276 L \text {, }
$$

where $y_{S}$ is the upper limit for the range of anticipated
abutment-scour depth, in feet; and

$L$ is the 100-year-flow embankment length, in feet; and should not exceed $950 \mathrm{ft}$.

Six observations of abutment scour (table 11) were excluded from figure 60 because they were outside the range for most of the data or because anomalies at the site made the measured data or modeled hydraulic variables questionable. Figure 61 shows the same information as figure 60 , but highlights the observed data from the 1995 flood. Several of the data points fall along or near the envelope, indicating that the curve provides some representation of the upper limit for abutment-scour depths that might occur at sites experiencing large flood flows.

The envelope in figure 60 encompasses the majority of field data, as well as all sites influenced by the 1995 flood, and it is reasonable to assume that it represents an upper range of potential scour for a given embankment length. With this assumption, the envelope can be used as a tool for assessing potential abutment-scour depths in the Piedmont. Because the envelope represents an upper limit of observed scour depth, it will likely overpredict scour depth for various site conditions; however, the envelope will not exceed the upper bound of observed field data. In contrast, theoretical scour computed with the Froehlich (1989) equation frequently exceeds the upper bound of observed data (fig. 62), indicating the embankmentlength envelope is a better method for assessing potential abutment-scour depths in the Piedmont. 
Table 11. Field observations excluded from the development of the embankment-length envelope curve (fig. 60) for the Piedmont of South Carolina

[U.S., United States Route; S.C., South Carolina Route; I, Interstate Highway]

\begin{tabular}{lllcrr} 
County & Road & \multicolumn{1}{c}{ Stream } & $\begin{array}{c}\text { Reference } \\
\text { number } \\
\text { in figure 1 } \\
\text { and } \\
\text { appendix B }\end{array}$ & $\begin{array}{c}\text { Embankment } \\
\text { length } \\
\text { (feet) }\end{array}$ & $\begin{array}{c}\text { Abutment } \\
\text { scour } \\
\text { depth } \\
\text { (feet) }\end{array}$ \\
\hline Chester $^{\text {b }}$ & I-77 & Fishing Creek & 14 & 1,593 & 0.0 \\
Laurens $^{c}$ & S.C. 72 & Little River & 89 & 52 & 13.3 \\
Laurens $^{\text {d }}$ & S.C. 72 & Duncan Creek & 90 & 473 & 17.0 \\
Newberry $^{\text {b.e }}$ & U.S. 176 & Kings Creek & 107 & 1,205 & 1.6 \\
Newberry $^{\text {b,f }}$ & S.C. 121 & Saluda River & 109 & 1,669 & 2.3 \\
Oconee $^{\mathrm{e}}$ & U.S. 76 & Coneross Creek & 114 & 711 & 0.0 \\
\hline
\end{tabular}

${ }^{a}$ Embankment length estimated from the WSPRO model (Shearman, 1990) using the theoretical 100-year flow.

${ }^{\mathrm{b}}$ Embankment length is beyond the range of the majority of observed data.

${ }^{\mathrm{c}}$ Abutment scour at this site is not created by classical abutment-scour processes. The channel at this site has a severe bend (approximately 90 degrees) upstream from the bridge. During high-flow conditions, flow jumps the main channel and enters the abutment region, creating the large abutment-scour depth. For more information on this site see the report section, "Effect of Upstream Channel Alignment."

${ }^{d}$ This is a multiple-bridge opening crossing that may have distributions of flow significantly different from a single-bridge opening. These irregular flow patterns make it difficult to estimate an embankment length and therefore this site was excluded from figure 60. For more information on multiple-bridge openings see the "Multiple-Bridge Openings" section under "Guidance for Assessing Abutment-Scour Depth with the Envelope Curves."

${ }^{\mathrm{e}}$ A small relief culvert in the road embankment makes the measured scour data questionable.

${ }^{\mathrm{f}} \mathrm{A}$ large road ditch on the upstream road embankment makes the measured scour data questionable.

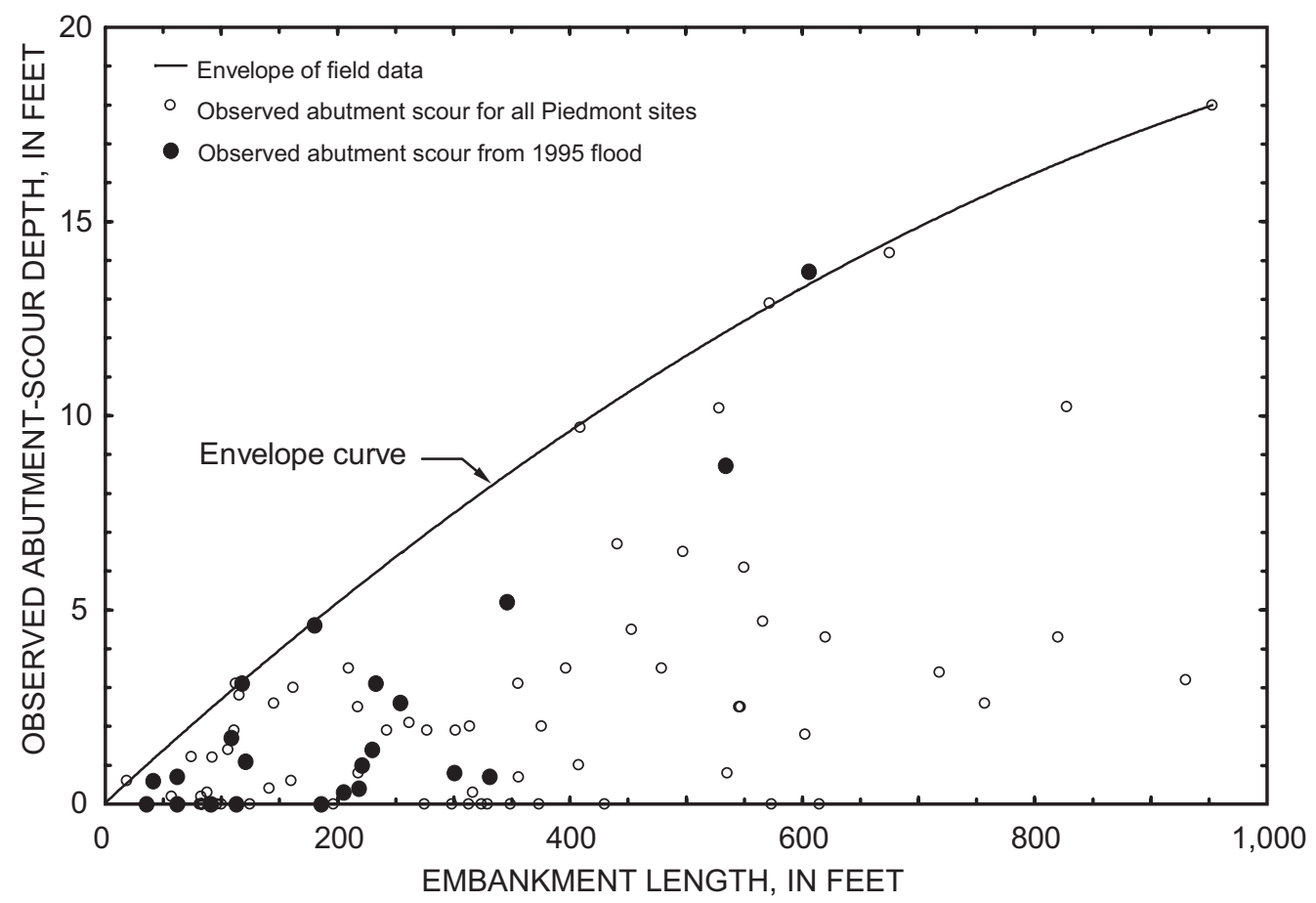

Figure 61. Relation of observed clear-water abutment-scour depth and the 100-year-flow embankment length with identification of the 1995 flood sites in the Piedmont of South Carolina. 


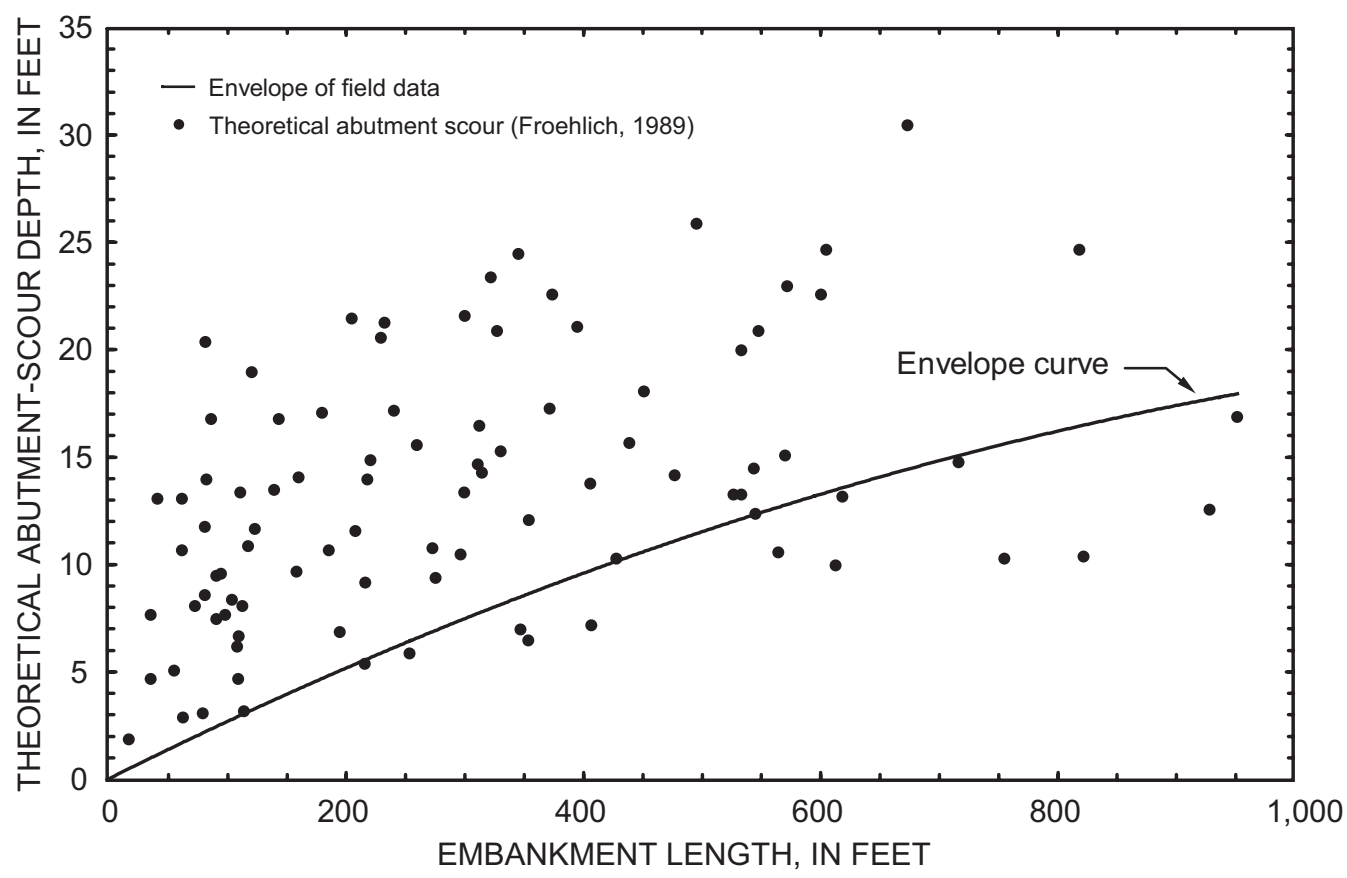

Figure 62. Relation of theoretical 100-year-flow abutment-scour depth and embankment length compared with the envelope of observed abutment scour for selected sites in the Piedmont of South Carolina. (Theoretical abutment scour calculated with the Froehlich (1989) equation.)

\section{Geometric-Contraction Ratio as an Indicator of Potential Scour}

The amount of flow contraction caused by a bridge can be assessed by using the geometric-contraction ratio, $m$, defined as $m=1-b / B$, where the variables are previously defined. In general, as the geometriccontraction ratio increases, the velocity and flow curvature at a bridge will rise, increasing the potential for scour. Therefore, deeper scour depths associated with larger geometric-contraction ratios were expected, as was the trend of the laboratory data shown in figure 56. This general trend is also apparent in the relation of observed scour depth and the 100-year-flow geometriccontraction ratio for field data in the Piedmont (fig. 63). The envelope of these data clearly indicates that larger abutment-scour depths are associated with larger geometric-contraction ratios. An equation for this envelope is:

$$
y_{s}=19.96 m^{2}+6.163 m,
$$

where

$$
\begin{aligned}
& y_{S} \text { is the upper limit of the range for anticipated } \\
& \text { abutment-scour depth in feet; and } \\
& m \text { is the 100-year-flow geometric-contraction ratio; }
\end{aligned}
$$

where

$m=1-b / B$ with the variables previously defined.

Because the largest observation of abutment scour in the Piedmont (18.0 ft) has a geometriccontraction ratio of 0.82 and an embankment length of $950 \mathrm{ft}$, the envelope curve should be limited to sites with geometric-contraction ratios and embankment lengths less than or equal to these values. Figure 64 shows the same information as figure 63 , but highlights the observed data from the 1995 flood. Several of the data points fall along or near the envelope, indicating that the curve provides some representation of the upper limit for abutment-scour depths that might occur at sites experiencing large flood flows. 


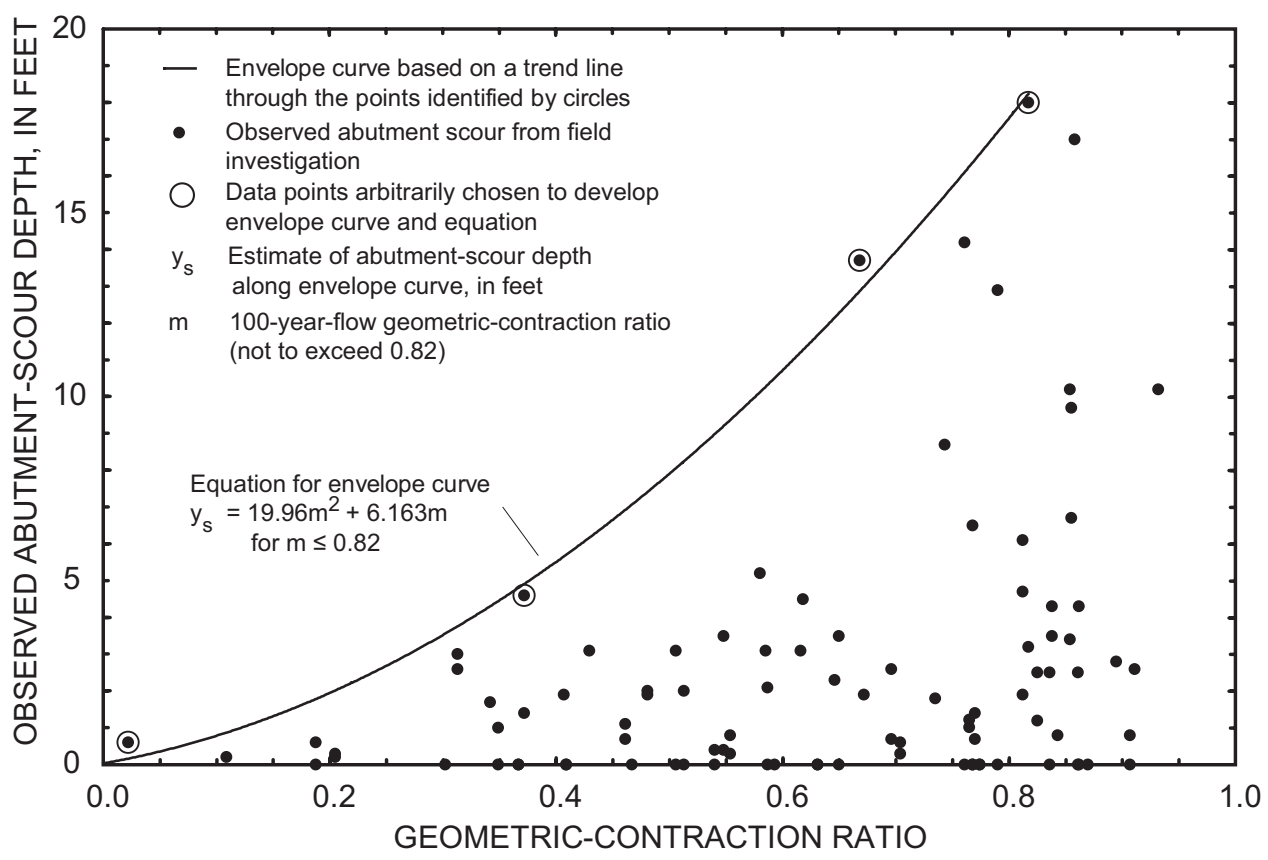

Figure 63. Relation of observed clear-water abutment-scour depth and the 100-year-flow geometric-contraction ratio in the Piedmont of South Carolina.

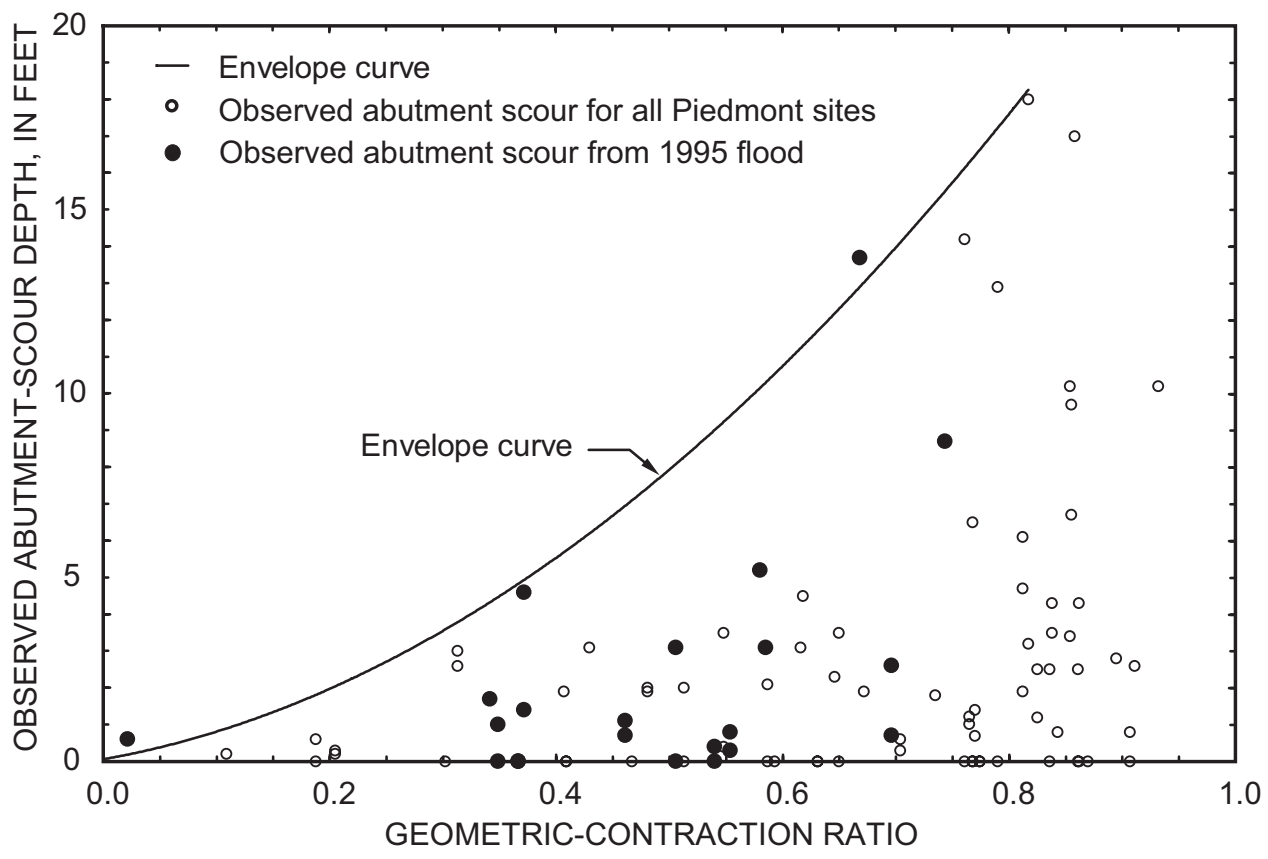

Figure 64. Relation of observed clear-water abutment-scour depth and the 100-year-flow geometric-contraction ratio with identification of the 1995 flood sites in the Piedmont of South Carolina. 
The envelope in figure 63 encompasses all field data, as well as all sites influenced by the 1995 flood, and it is reasonable to assume that it represents an upper range of potential scour for a given geometriccontraction ratio. With this assumption, the envelope can be used as a tool for assessing potential abutmentscour depths in the Piedmont. Because the envelope represents an upper limit of observed scour depth, it will likely overpredict scour depth for various site conditions; however, the envelope will not exceed the upper bound of observed field data. In contrast, theoretical scour computed with the Froehlich (1989) equation frequently exceeds this upper bound (fig. 65). For geometric-contraction ratios of 0.75 or less, 45 of the 55 theoretical values exceed the envelope, indicating that this part of the envelope will provide better estimates of abutment scour. For ratios greater than $0.75,38$ of the 45 theoretical values fall below the envelope, indicating that this part of the envelope may overpredict scour depths. This overprediction can be attributed to the dimensionless character of the geometric-contraction ratio that obscures the effect of embankment length. This will be discussed in more detail in the report section, "Selecting the Appropriate Abutment-Scour Depth Envelope."

\section{Floodplain Land Cover as an Indicator of Potential Scour}

Perhaps the most commonly observed land cover for floodplains in the Piedmont of South Carolina is forest. Forested floodplains have relatively high resistance to flow compared to the main channel. The highflow resistance reduces flow velocities and the percentage of total flow carried by the floodplain. When floodplain flow resistance is significantly reduced, flow velocities and the percentage of total flow carried by the floodplain will increase. This, in turn, will increase the potential for abutment scour. Reduction in floodplain flow resistance can occur when forested floodplains are clearcut for timber harvest or are converted to pastures. To provide some perspective of the impact that changes in flow resistance can have on floodplain flows, the right floodplain of Cannons Creek at Road S-299 in Newberry County was modeled for forested and pastured conditions. Table 12 lists the right floodplain average velocity and flow, showing a significant difference between these conditions.

Figure 66 shows the relation of observed abutment-scour depth and the 100-year-flow embankment length, identifying sites with reduced flow resistance

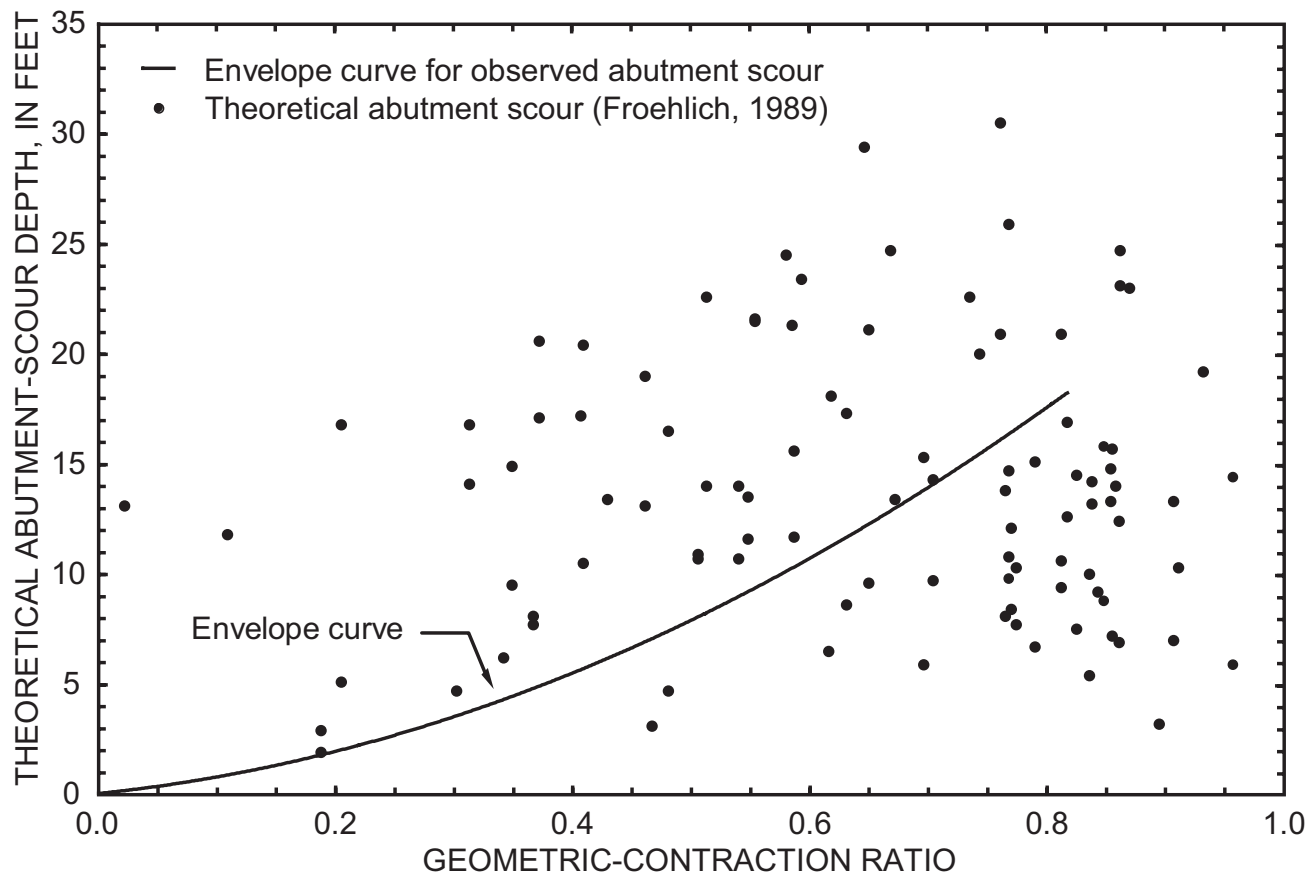

Figure 65. Relation of theoretical 100-year-flow abutment-scour depth and the 100-year-flow geometric-contraction ratio compared with the envelope of observed data in the Piedmont of South Carolina. (Theoretical abutment scour calculated with the Froehlich (1989) equation.) 
Table 12. The effect of changing floodplain flow resistance exemplified by model data at Structure 367029900100 on Road S-299, crossing Cannons Creek in Newberry County, South Carolina

[ft ${ }^{3} / \mathrm{s}$, cubic feet per second; $\mathrm{ft} / \mathrm{s}$, feet per second]

\begin{tabular}{|c|c|c|c|}
\hline $\begin{array}{l}\text { Right } \\
\text { floodplain } \\
\text { land cover }\end{array}$ & $\begin{array}{l}\text { Estimate of } \\
\text { Manning's } \\
\text { roughness } \\
\text { coefficient } \\
\text { on right } \\
\text { floodplain }\end{array}$ & $\begin{array}{c}\text { Flow } \\
\text { on right } \\
\text { floodplain } \\
\left(\mathrm{ft}^{3} / \mathrm{s}\right)^{\mathrm{a}}\end{array}$ & $\begin{array}{c}\text { Average } \\
\text { flow velocity } \\
\text { on right } \\
\text { floodplain } \\
(\mathrm{ft} / \mathrm{s})^{\mathrm{a}}\end{array}$ \\
\hline Forest & 0.16 & 430 & 0.3 \\
\hline Pasture & 0.035 & 1,510 & 1.1 \\
\hline
\end{tabular}

${ }^{\text {a }}$ Estimated from the WSPRO model (Shearman, 1990) using the theoretical 100-year flow.

caused by pastures or timber harvest. Three categories of sites are identified: (1) sites that had pastures at the time of the site visit; (2) sites that had woods at the time of the site visit, but had strong evidence of pastures or timber harvest in the past; and (3) sites that had sparse woods at the time of the site visit, and weak evidence of existing pastures or timber harvest in the past. A noteworthy observation is that these sites include all but one of the observed abutment-scour depths greater than $6.5 \mathrm{ft}$. These sites also form the boundary of the envelope for scour depths $9.7 \mathrm{ft}$ or greater. This suggests that sites with lowered flow resistance have a high abutment-scour potential. The lowered floodplain flow resistance is not sufficient, in itself, to produce large scour depths, and also must be accompanied by a significant contraction of flow as well as soils that will scour for the given conditions.

Because site histories are incomplete, the floodplain land cover at the time the observed scour holes were created is not known, and the scour-producing floods might have occurred at these sites when the floodplains were forested. If this is the case, then observed scour cannot be associated with a reduction in flow resistance. However, the data in figure 66 strongly suggests that the risk of greater scour depths increases when flow resistance is lowered by clear-cutting or conversion to pasture land. Because observed data at floodplains with lowered flow resistance fall near or on the boundary of both the embankment-length and the geometric-contraction-ratio envelope curves, it is reasonable to assume that the envelope curves will account for such conditions. When assessing abutment scour in the Piedmont, one should carefully consider existing and future conditions that could lower flow resistance and, in turn, increase scour potential.

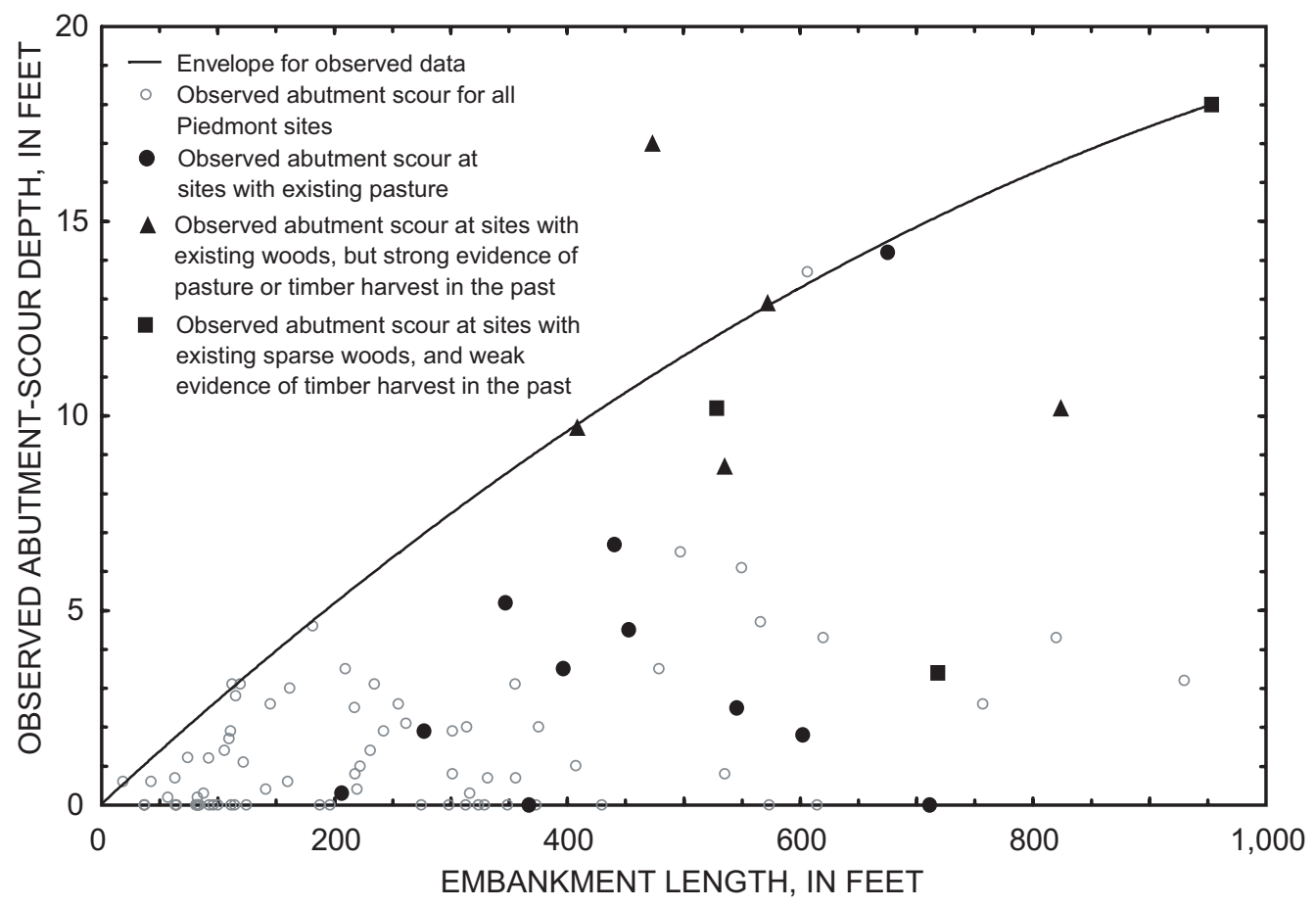

Figure 66. Relation of observed clear-water abutment-scour depth and the 100-year-flow embankment length with the identification of sites with lowered floodplain flow resistance for the Piedmont of South Carolina. 


\section{ABUTMENT SCOUR IN THE COASTAL PLAIN}

A total of 109 observations of clear-water abutment scour were collected at 81 bridge sites in the Coastal Plain of South Carolina, consisting of 7 observations from the upper Coastal Plain and 102 from the lower Coastal Plain. Eleven of the 81 bridges have a significant main channel conveying water through the bridge. The remaining 70 bridges are located on swampy floodplains where shallow low-flow channels convey only a small percentage of the total flow. For the 11 bridges with main channels, the abutment configuration is a setback abutment where the toe of the abutment is located on the floodplain at some distance away from the main channel (fig. 53). For the swampy bridges, the abutment configuration is similar to the setback abutment, excluding the main channel, and the bridges resemble floodplain relief bridges (fig. 29). Three of the abutments are vertical wing walls with the remainder being spill-through abutments.

A plot of observed abutment scour in the Coastal Plain and Piedmont of South Carolina indicates that larger scour depths occur more frequently in the Coastal Plain than in the Piedmont (fig. 67).
These larger scour depths can be attributed to the longer embankment lengths and larger contraction ratios associated with the wider floodplains of the Coastal Plain. In addition, the scour-susceptible soils and longer flow durations of the Coastal Plain promote larger scour depths. Figure 68 is a plot of the observed floodplain widths for this study and gives some perspective on the more common occurrence of wide river valleys in the Coastal Plain compared with the Piedmont. Table 13 provides the range for selected parameters associated with the 109 abutment-scour observations. Values for hydraulic data were estimated with the WSPRO (Shearman, 1990) model using the 100-year flow.

\section{Abutment-Scour Hole Patterns}

In general, two scour-hole patterns were observed in the Coastal Plain. For smaller bridges (approximately $240 \mathrm{ft}$ in length or less) it was common to find a large, single scour hole with a top width that often encompassed the entire bridge opening (fig. 69).

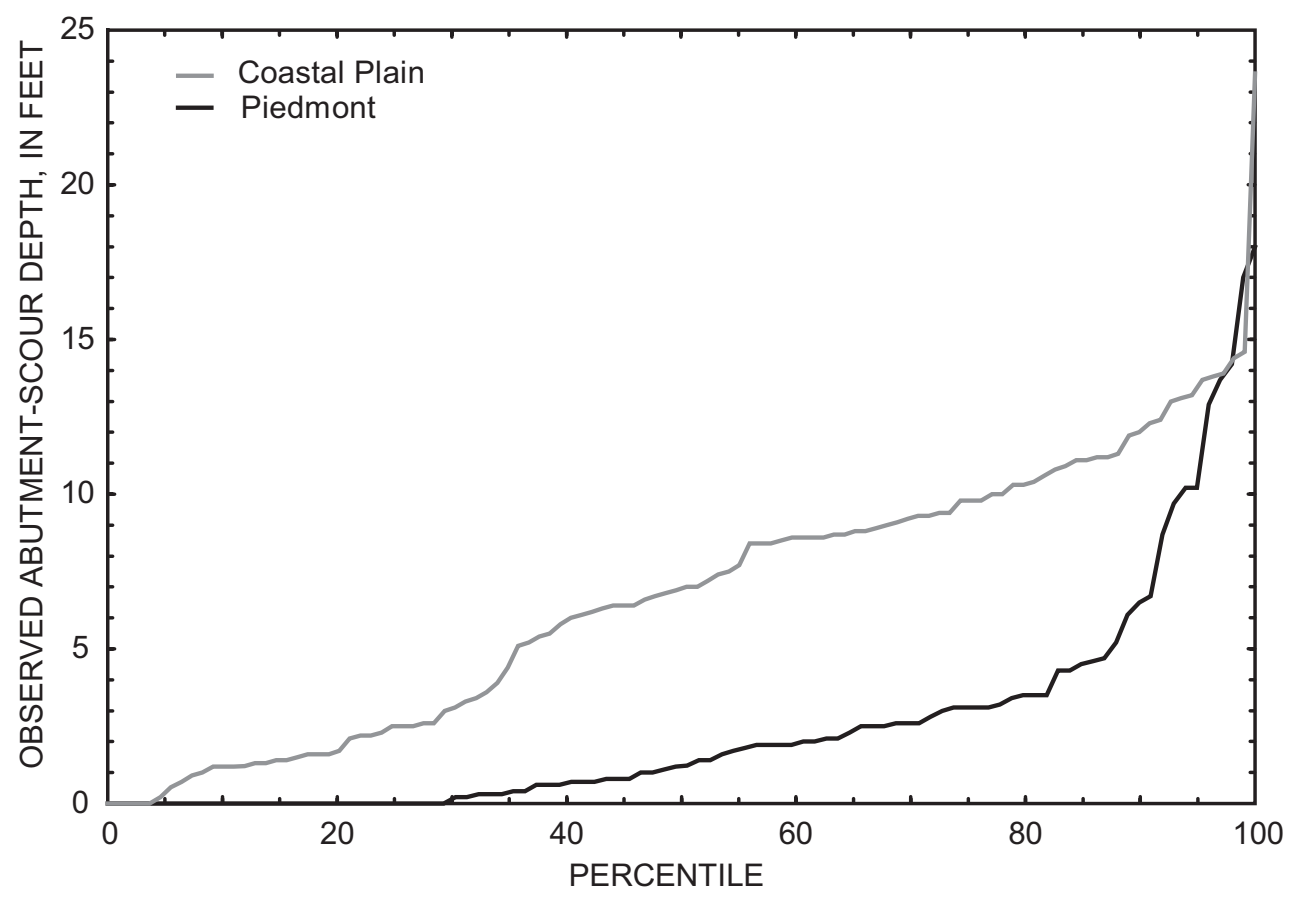

Figure 67. Percentile of observed clear-water abutment-scour depth in the Piedmont and Coastal Plain of South Carolina. 


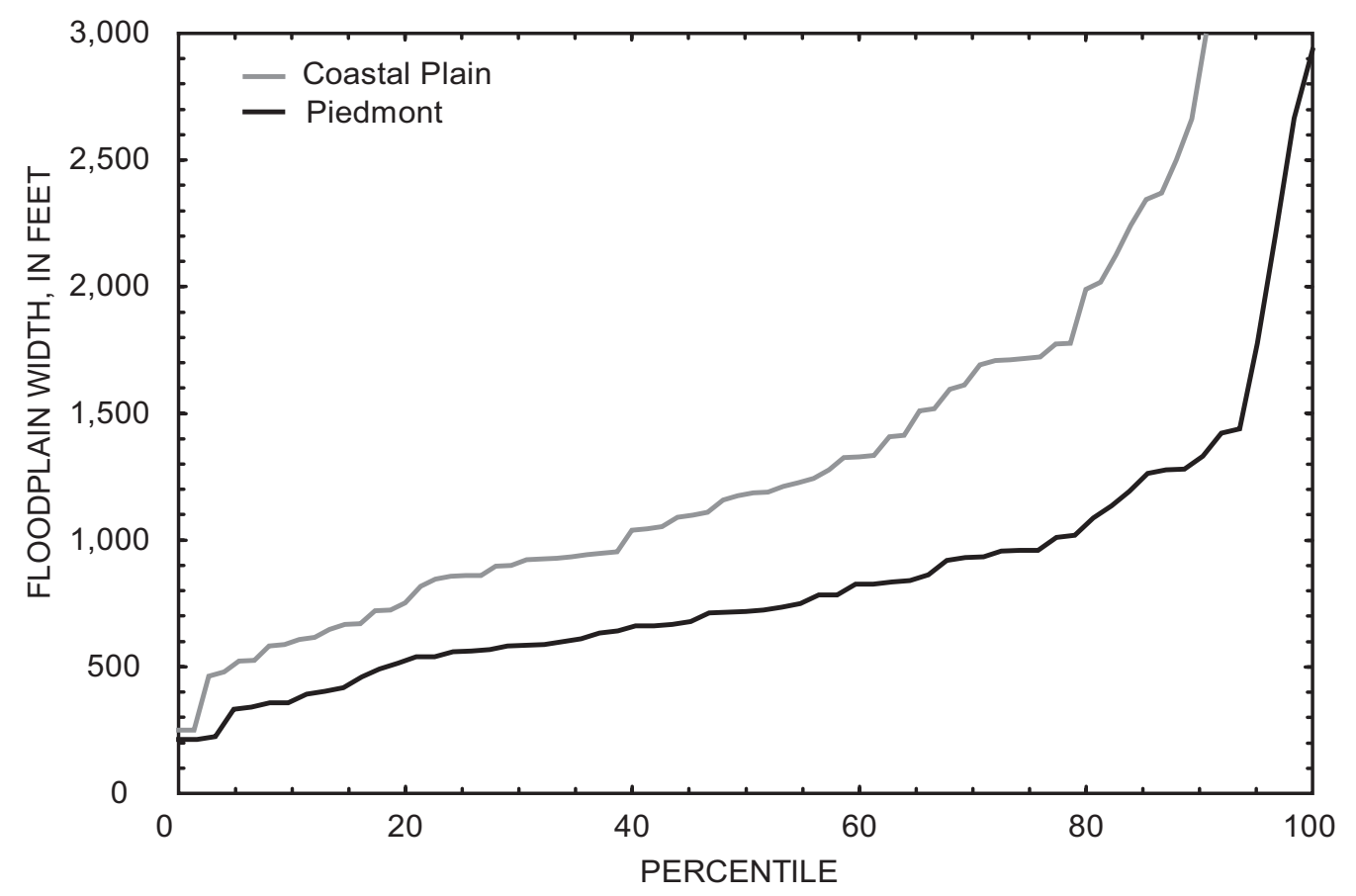

Figure 68. Percentile of the 100-year-flow floodplain width for study sites in the Piedmont and Coastal Plain of South Carolina. (NOTE: The vertical scale has been truncated in order to provide detail for the smaller floodplain widths.)

Table 13. Range of selected parameters for 109 observations of clear-water abutment scour collected at 81 bridges in the Coastal Plain of South Carolina

$\left[\mathrm{mi}^{2}\right.$, square mile; ft/ft., feet per foot; $\mathrm{ft} / \mathrm{s}$, feet per second; $\mathrm{ft}$, feet; $\mathrm{mm}$, millimeter; <, less than]

\begin{tabular}{|c|c|c|c|}
\hline Parameter & $\begin{array}{l}\text { Mini- } \\
\text { mum } \\
\text { value }\end{array}$ & $\begin{array}{l}\text { Median } \\
\text { value }\end{array}$ & $\begin{array}{l}\text { Maxi- } \\
\text { mum } \\
\text { value }\end{array}$ \\
\hline Drainage area $\left(\mathrm{mi}^{2}\right)$ & 6.0 & 120 & a 8,830 \\
\hline $\begin{array}{l}\text { Channel slope determined from topo- } \\
\text { graphic map (ft/ft) }\end{array}$ & 0.00007 & 0.0005 & 0.0024 \\
\hline $\begin{array}{l}\text { 100-year average approach velocity } \\
\text { obstructed by embankment (ft/s) }\end{array}$ & 0.1 & 0.5 & 1.6 \\
\hline $\begin{array}{l}\text { 100-year average approach depth } \\
\text { obstructed by embankment (ft) }\end{array}$ & 1.5 & 4.7 & 17.4 \\
\hline $\begin{array}{l}\text { Embankment length based on } \\
100 \text {-year flow (ft) }{ }^{b}\end{array}$ & 87 & 557 & ${ }^{\mathrm{c}} 7,440$ \\
\hline Median grain size (mm) & $<0.062$ & 0.18 & 0.780 \\
\hline Observed abutment-scour depth (ft) & 0.0 & 7.0 & 23.6 \\
\hline
\end{tabular}

a Approximately 80 percent of the study sites in the Coastal Plain have drainage areas less than $426 \mathrm{mi}^{2}$ (fig. 3).

b Parameter was estimated from the one-dimensional water-surface profile model, WSPRO (Shearman, 1990).

${ }^{\mathrm{c}}$ Only seven observations have embankment lengths that exceed $2,000 \mathrm{ft}$.
In contrast, bridges exceeding $240 \mathrm{ft}$ in length tended to develop separate scour holes at each abutment (fig. 70). This phenomenon at shorter bridges appears to be caused by the overlap of turbulent and curvilinear flow coming from the left and right abutments. If the bridge had been sufficiently long to prevent the overlap of these flow patterns, then separate left and right abutment-scour holes, typically found at longer bridges, would likely have developed. Because the large, single scour holes at shorter bridges appear to be created by turbulent flow patterns typically associated with abutment scour, it was assumed that these scour holes should be classified as abutment scour. To associate the single scour holes at short bridges with abutment variables, it was assumed that the longer of the left or right abutments provided the stronger influence in developing the scour hole and should be associated with the observed scour. For example, U.S. Route 301 crossing Douglas Swamp in Florence County has an 88-ft-long bridge with a single scour hole that is $10.6 \mathrm{ft}$ deep (fig. 69). The left and right embankment lengths for the 100-year flow were 452 and $695 \mathrm{ft}$, respectively. 


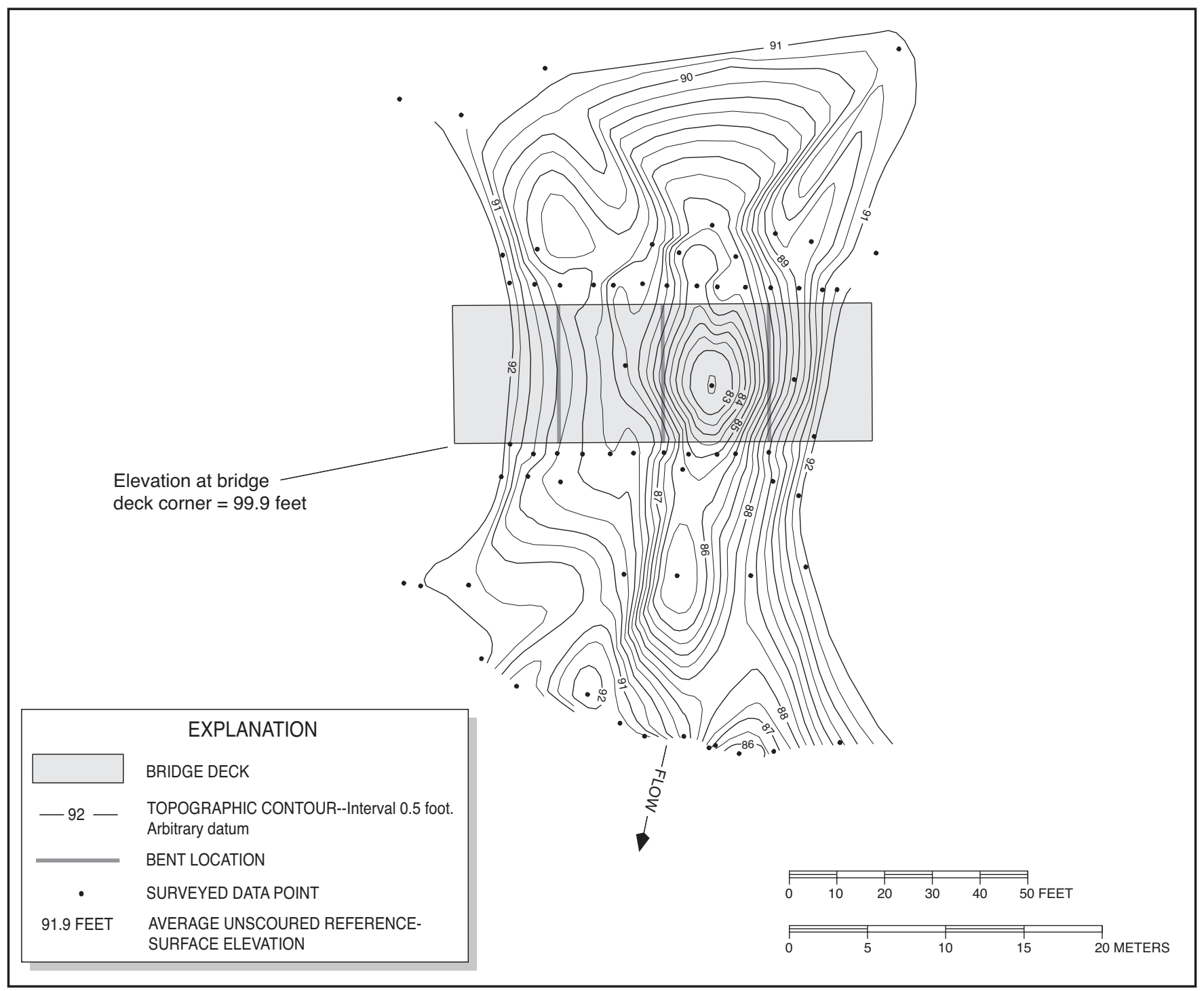

Figure 69. Example of single scour hole at shorter bridges in the Coastal Plain, as shown at Structure 212030100100 on U.S. Route 301, crossing Douglas Swamp in Florence County, South Carolina, July 31, 1996.

Therefore, hydraulic variables for the longer embankments $(695 \mathrm{ft})$ such as flow velocity, flow depth, and embankment length, were associated with the observed scour at this site. Hydraulic variables for all of the large, single scour holes were obtained in this manner. This assumption should be kept in mind when reviewing hydraulic abutment data from sites that display this pattern. These data, along with sites with distinct left and (or) right abutment-scour holes, were used to develop the embankment-length envelope curve presented later in the report.

\section{Comparison of Observed and Theoretical Abutment-Scour Depths}

To estimate theoretical abutment-scour depth for clear-water scour conditions, HEC-18 (Richardson and Davis, 1995) recommends the use of Froehlich's (1989) equation (eq. 9), which was derived from laboratory data for noncohesive sediments. Because the sandy soils and nearly rectangular floodplains associated with the Coastal Plain are similar to laboratory conditions, Froehlich's equation may perform better in 


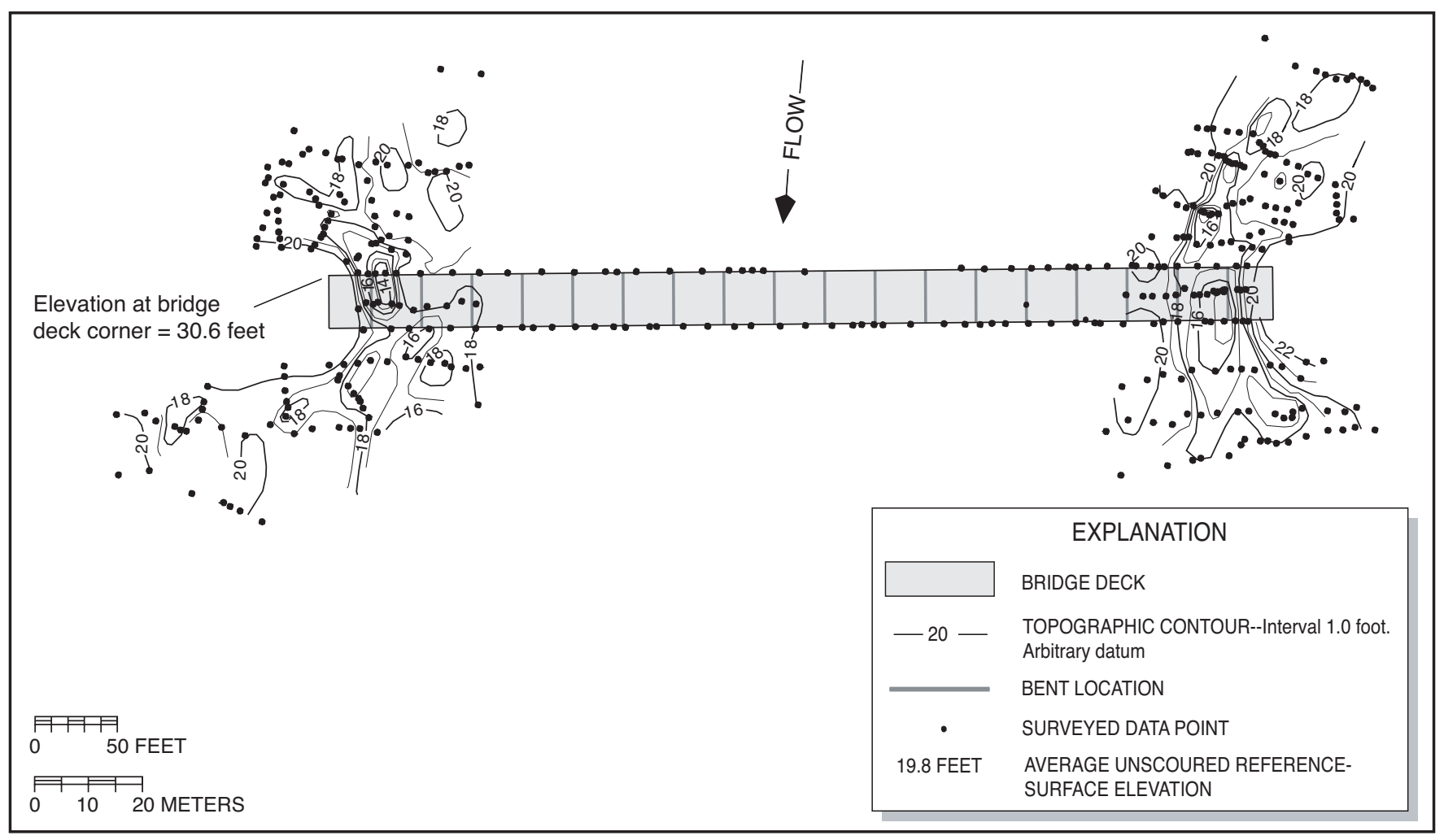

Figure 70. Example of separate left and right abutment-scour holes at longer bridges in the Coastal Plain, as shown at Structure 277008700100 on Road S-87, crossing the Coosawhatchie River in Jasper County, South Carolina, November $12,1997$.

this region than in the Piedmont. Figure 71A compares the theoretical abutment-scour depth computed for the 100-year flow with the observed abutment-scour depth. Note that the Froehlich equation overpredicts scour for sites where less than $7 \mathrm{ft}$ of scour was observed and begins to underpredict scour for sites with observed scour greater than $7 \mathrm{ft}$, indicating that the equation cannot be relied upon to always provide conservative design estimates of scour depth. Although the Froehlich equation performs better in the Coastal Plain than in the Piedmont, the results still have significant error.

As with the Piedmont, it should be kept in mind that flows that created the observed abutment-scour depths in the Coastal Plain are unknown for most sites. It is possible that the discrepancy between the observed and theoretical scour depths may be attributed to historic flows at these sites differing from the 100-year flow magnitude; however, maximum historic flows have been documented at 23 bridges in the Coastal Plain (tables 4 and 8). Eight of the bridges experienced the October 1992 flood where flows equaled or exceeded the 100-year magnitude at seven of these sites.
Seven bridges experienced the September 1999 flood along the Waccamaw River where flows exceeded the 100-year magnitude. Eight bridges along the Pee Dee and Little Pee Dee River have maximum historic flows near the 25-year flow. Comparing the theoretical abutment-scour depth computed with the maximum historic flow with the observed scour indicates excessive scour depths given by Froehlich's equation (fig. 71B). The results of figure $71 \mathrm{~A}$ are based on the hypothetical 100-year flow, whereas figure 71B represents observed and theoretical scour for known maximum historic flows. Therefore, the results of figure 71B likely provide a better indicator of how well the Froehlich equation predicts theoretical scour in the Coastal Plain. Both figures, however, show that large discrepancies between observed and theoretical scour depths can exist, suggesting that the Froehlich equation is a poor predictor for abutment scour at Coastal Plain sites and that another method should be used to estimate abutment scour in this region. 
A.

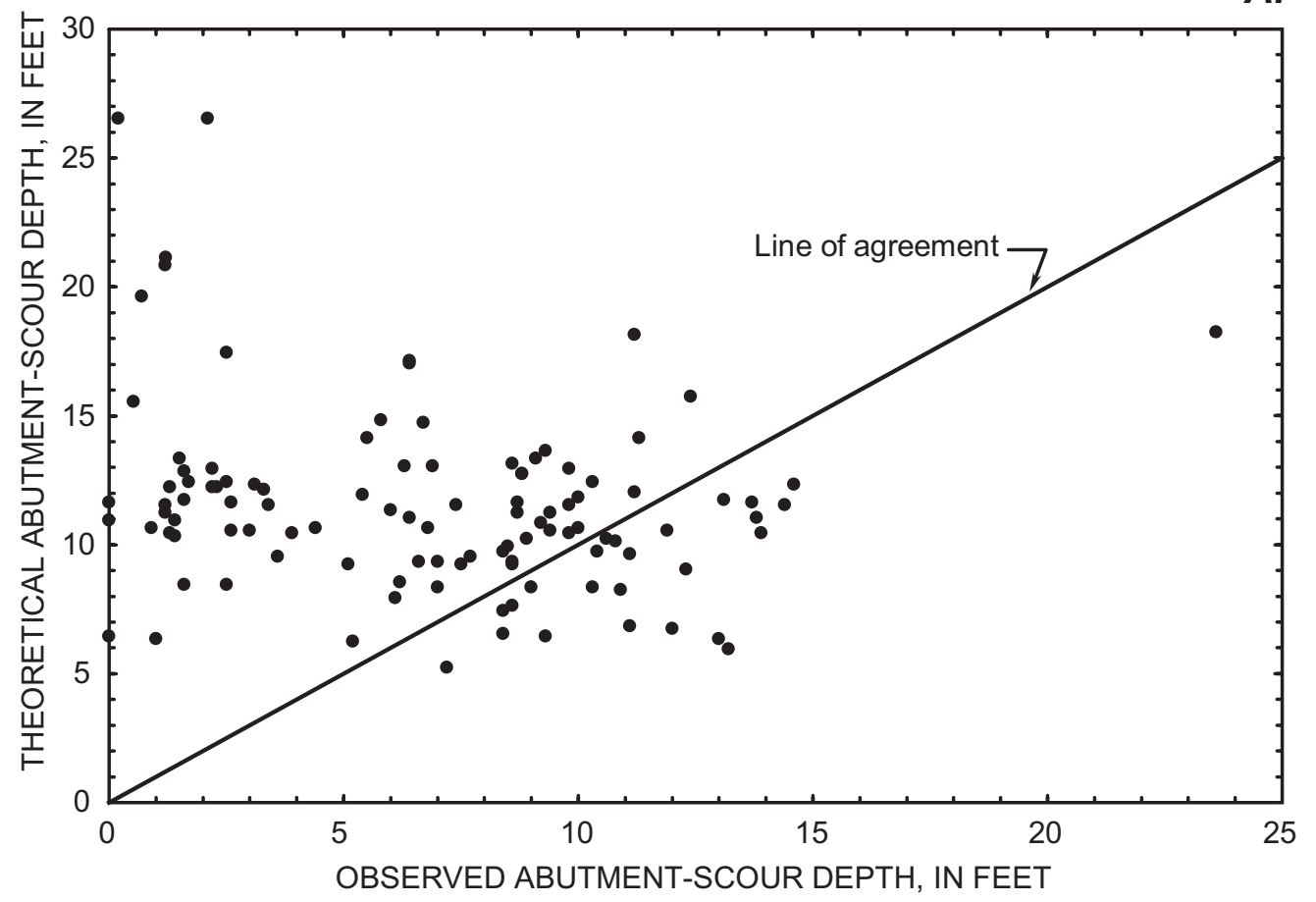

B.

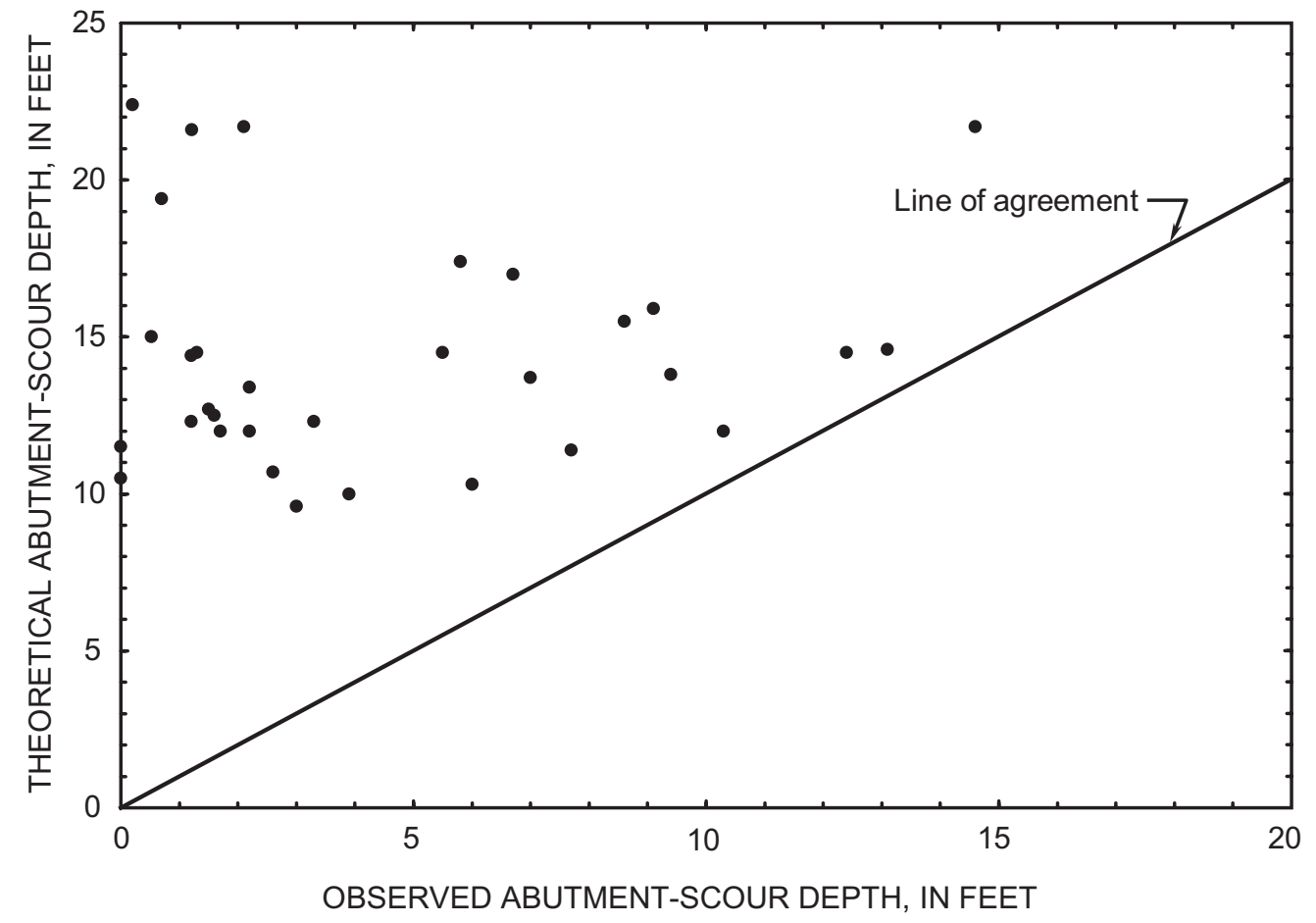

Figure 71. Relation of observed clear-water abutment-scour depth with theoretical abutmentscour depth for the (A) 100-year flow, and the (B) maximum historic flow at selected sites in the Coastal Plain of South Carolina. (Theoretical abutment scour calculated with the Froehlich (1989) equation.) 


\section{Embankment Length as an Indicator of Potential Scour}

Similar to abutment scour in the Piedmont, embankment length can provide some indication of the anticipated range of scour depth for Coastal Plain sites. Comparing the observed scour depths in the Coastal Plain with the embankment length for the 100-year flow, larger scour depths are associated with longer embankment lengths (fig. 72A). (Figure 72B is similar to figure $72 \mathrm{~A}$ with the horizontal scale truncated to 2,000 ft to provide more detail for smaller embankment lengths.) The envelope curve for the observed data suggests that the influence of embankment length decreases with increasing embankment length, which is consistent with trends from laboratory investigations. A series of equations for this envelope is:

$$
\begin{gathered}
L \leq 426, \mathrm{y}_{\mathrm{s}}=0.0338 L, \text { and } \\
426<L \leq 7,440, \mathrm{y}_{\mathrm{s}}=14.4+0.00131(L-426),
\end{gathered}
$$

where

$y_{S}$ is the upper limit for the range of anticipated abutment-scour depth, in feet; and

$L$ is the 100-year-flow embankment length, in feet.

This envelope and associated equation are limited to embankment lengths of 7,440 ft, and because of sparse field observations, may not fully represent trends for embankment lengths exceeding 2,000 ft. Figure 73 shows the same information as figure $72 \mathrm{~A}$, but highlights the observed data from the 1992 and 1999 floods. Several of the data points fall along or near the envelope, indicating that the curve provides some representation of the upper limit for abutment-scour depths that might occur at sites experiencing large flood flows.

The envelope in figure 72 encompasses the majority of field data, as well as all sites influenced by the 1992 and 1999 floods, and it is reasonable to assume that the envelope represents an upper range of potential scour depth for a given embankment length. With this assumption, the envelope can be used as a tool for assessing potential abutment-scour depths in the Coastal Plain. Figure 74 compares theoretical scour, computed with the Froehlich (1989) equation, with the embankment-length envelope. Most of the theoretical values are within the envelope, indicating that the Froehlich equation may often provide reasonable results in Coastal Plain of South Carolina. However, figure $71 \mathrm{~A}$ indicates that the Froehlich equation can occasionally underpredict scour depth by as much as $7.3 \mathrm{ft}$. Because the envelope represents the upper bound of observed data, underprediction is minimized, making the envelope a preferable method for assessing potential abutment-scour depths in the Coastal Plain.

\section{Geometric-Contraction Ratio as an Indicator of Potential Scour}

As with abutment scour in the Piedmont, the geometric-contraction ratio provides some indication of the potential for abutment scour at Coastal Plain bridges. Comparing the observed scour depths in the Coastal Plain with the geometric-contraction ratio for the 100-year flow, the data clearly show an increase in abutment-scour depth with increasing geometriccontraction ratio (fig. 75). An equation for this envelope is:

$$
y_{s}=29.62 m^{3}-10.182 m^{2}+5.538 m,
$$

where

$y_{S}$ is the upper limit for the range of anticipated abutment-scour depth, in feet; and

$m$ is the 100-year-flow geometric-contraction ratio; where

$m=1-b / B$ with the variables previously defined.

This envelope and associated equation are limited to geometric-contraction ratios of 0.98 or less and embankment lengths of 7,440 ft, and because of sparse field observations, may not fully represent trends for embankment lengths exceeding 2,000 ft. Figure 76 shows the same information as figure 75, but highlights the observed data from the 1992 and 1999 floods. Several of the data points fall near the envelope, indicating that the curve provides some representation of the upper limit for abutment-scour depths that might occur at sites experiencing large flood flows.

The envelope in figure 75 encompasses all field data, as well as all sites influenced by the 1992 and 1999 floods, and it is reasonable to assume that it represents an upper range of potential scour depth for a given geometric-contraction ratio. Based on this assumption, the envelope can be used as a tool for assessing potential abutment-scour depths in the Coastal Plain. Figure 77 compares theoretical scour, computed using the Froehlich (1989) equation, with the 
A.

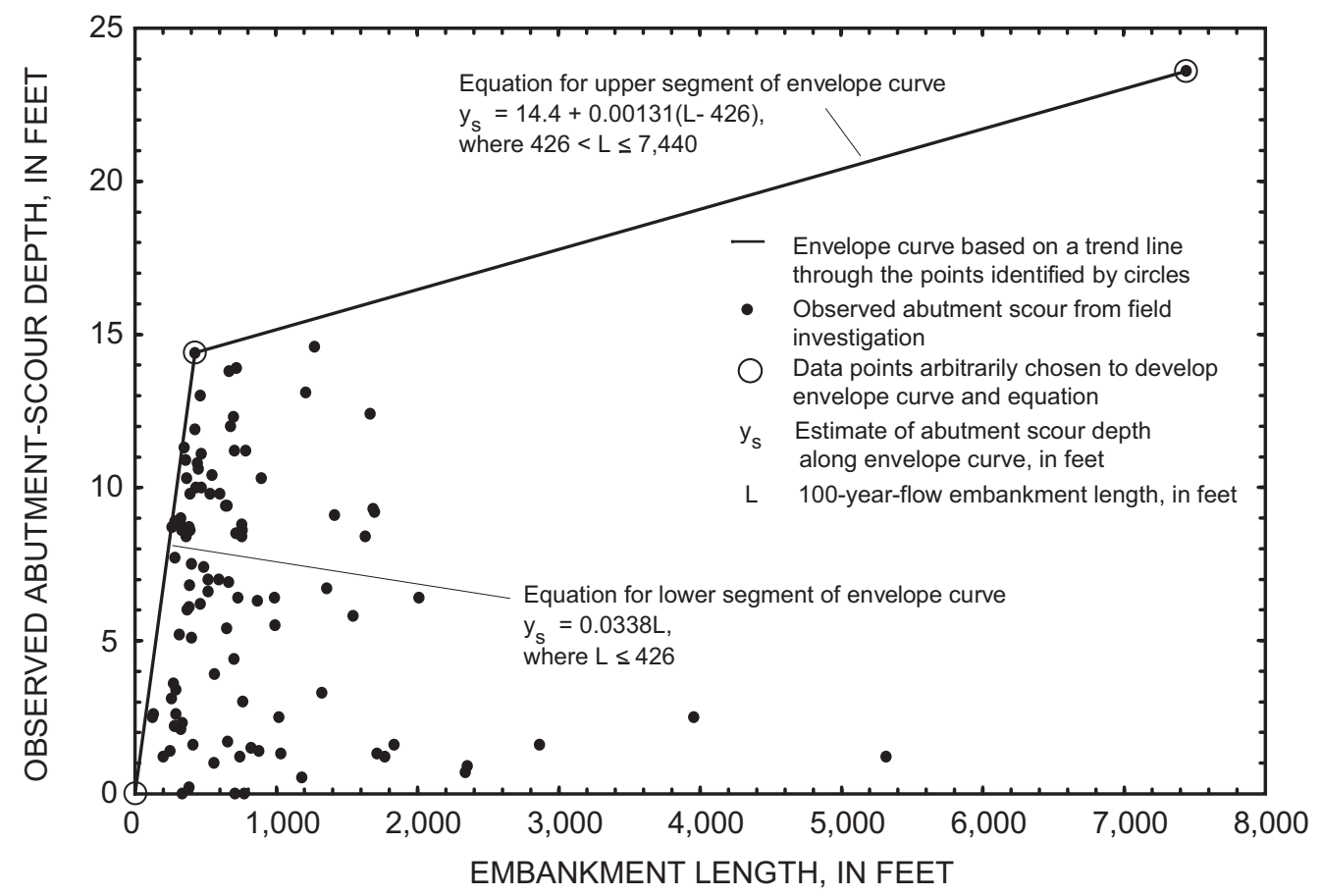

B.

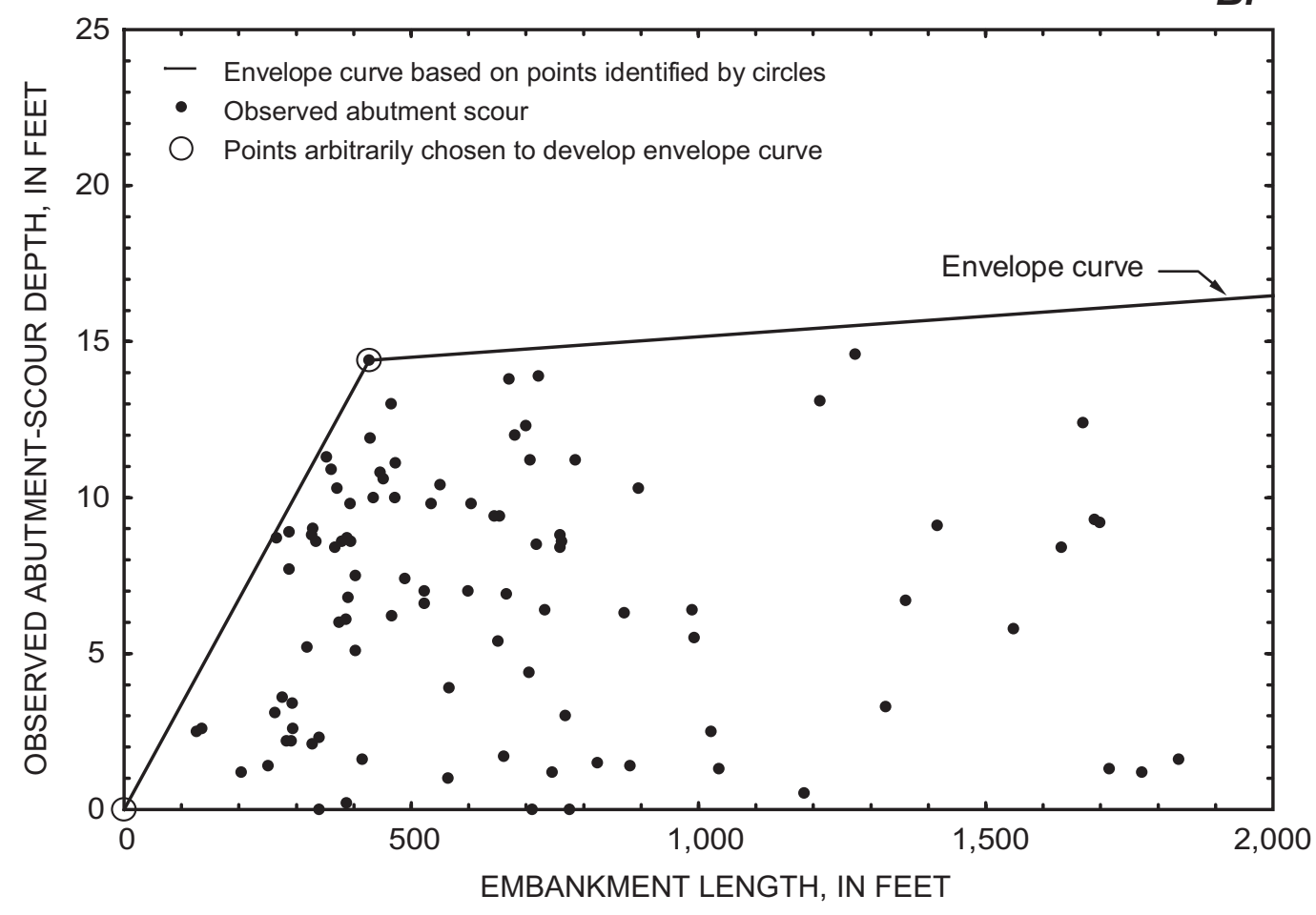

Figure 72. Relation of observed clear-water abutment-scour depth and the 100-year-flow embankment length for the Coastal Plain of South Carolina with a (A) complete horizontal axis and a (B) truncated horizontal axis. 


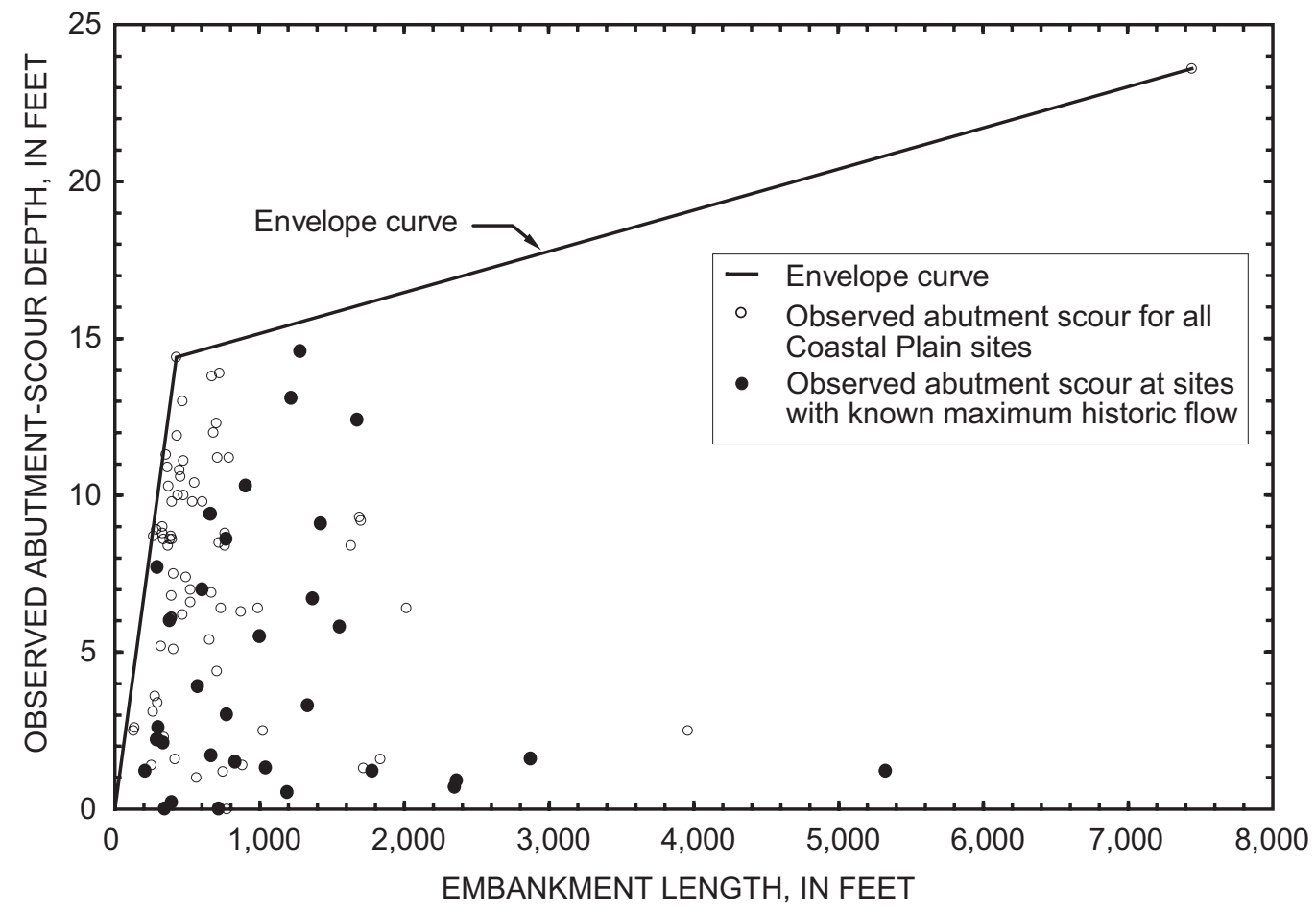

Figure 73. Relation of observed clear-water abutment-scour depth and the 100-year-flow embankment length identifying the 1992 and 1999 flood sites in the Coastal Plain of South Carolina.

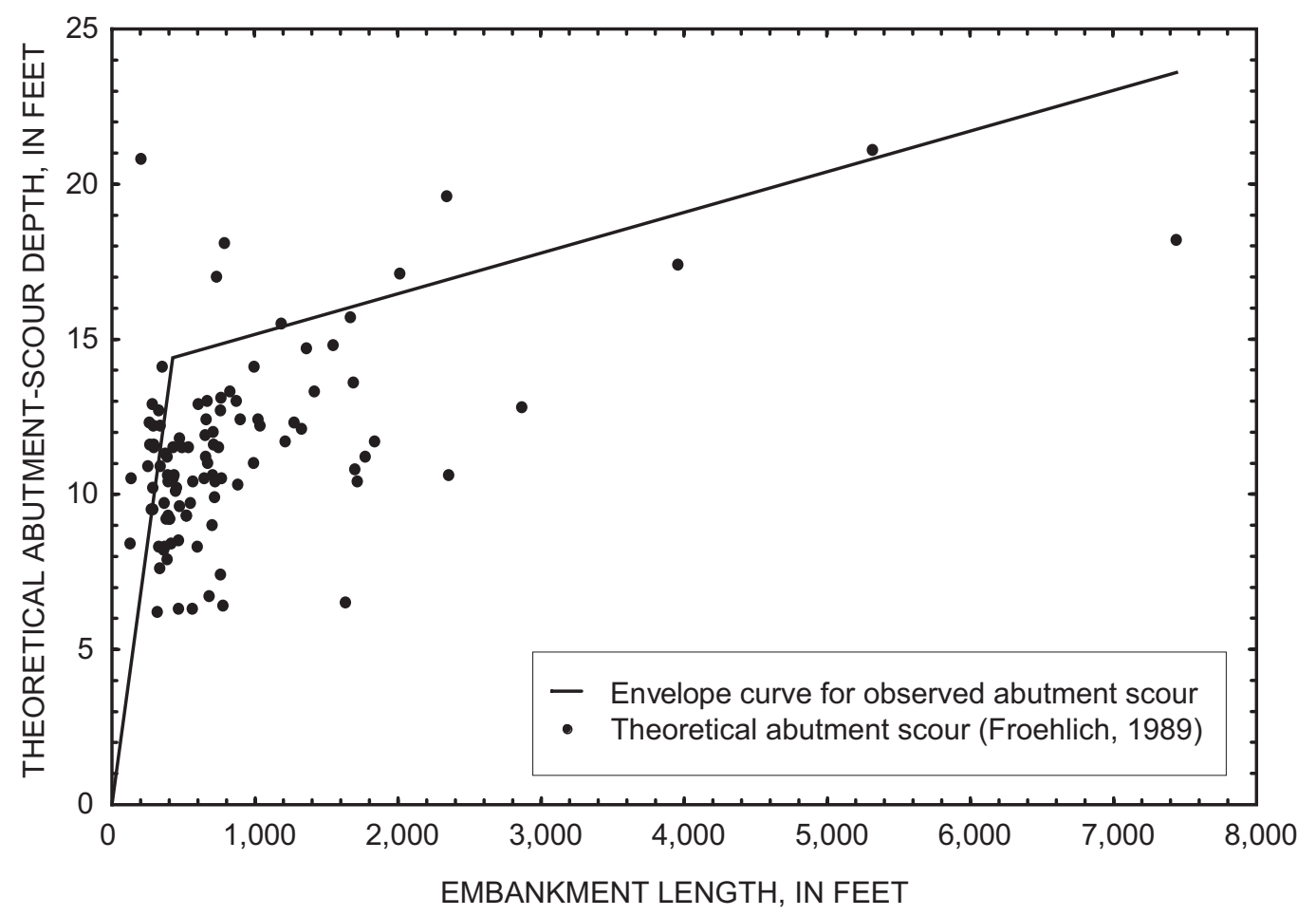

Figure 74. Relation of theoretical 100-year-flow abutment-scour depth and the 100-year-flow embankment length compared with the envelope of observed abutment scour for selected sites in the Coastal Plain of South Carolina. (Theoretical abutment scour calculated with the Froehlich (1989) equation.) 


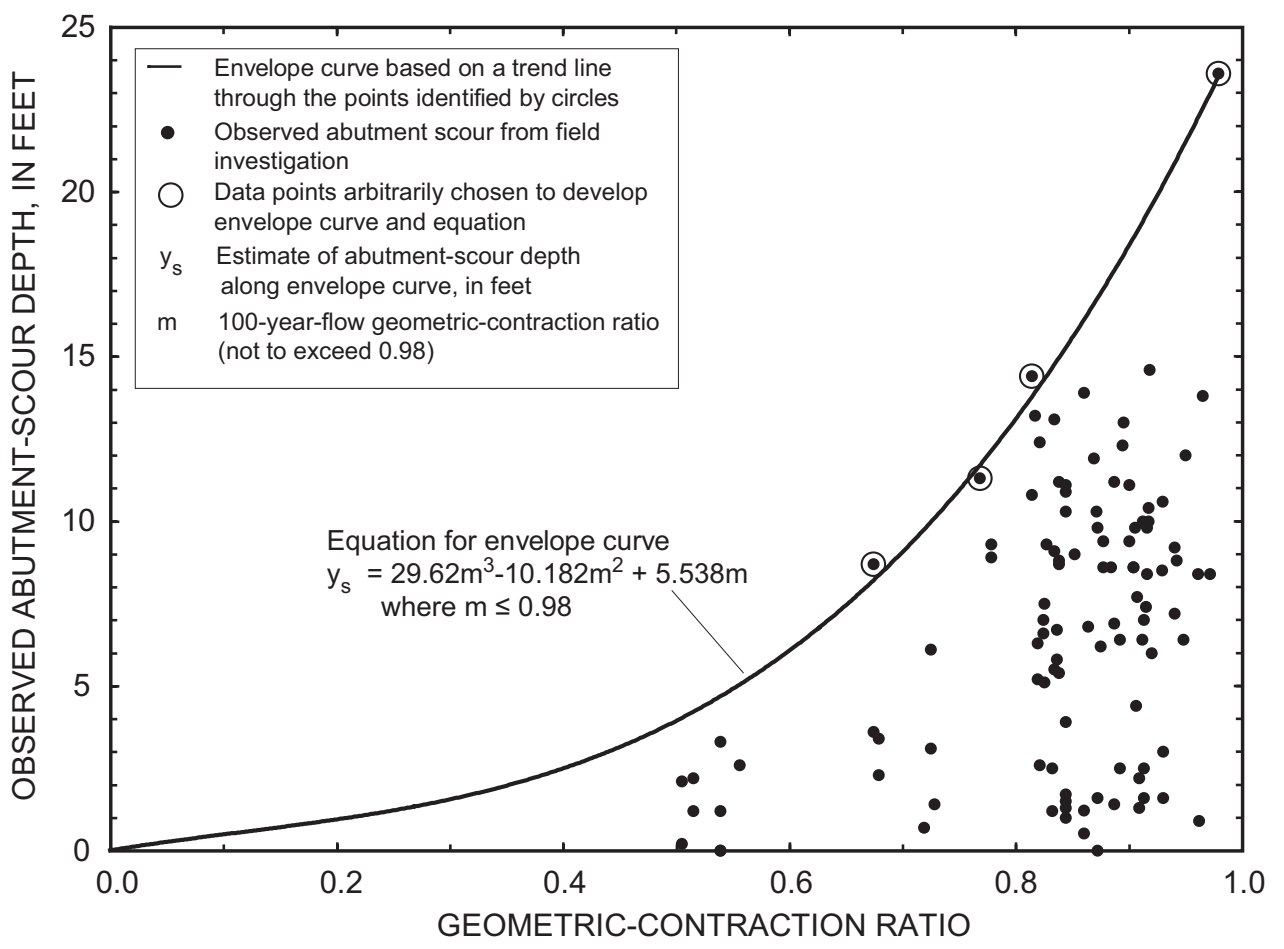

Figure 75. Relation of observed clear-water abutment-scour depth and the 100-year-flow geometric-contraction ratio for the Coastal Plain of South Carolina.

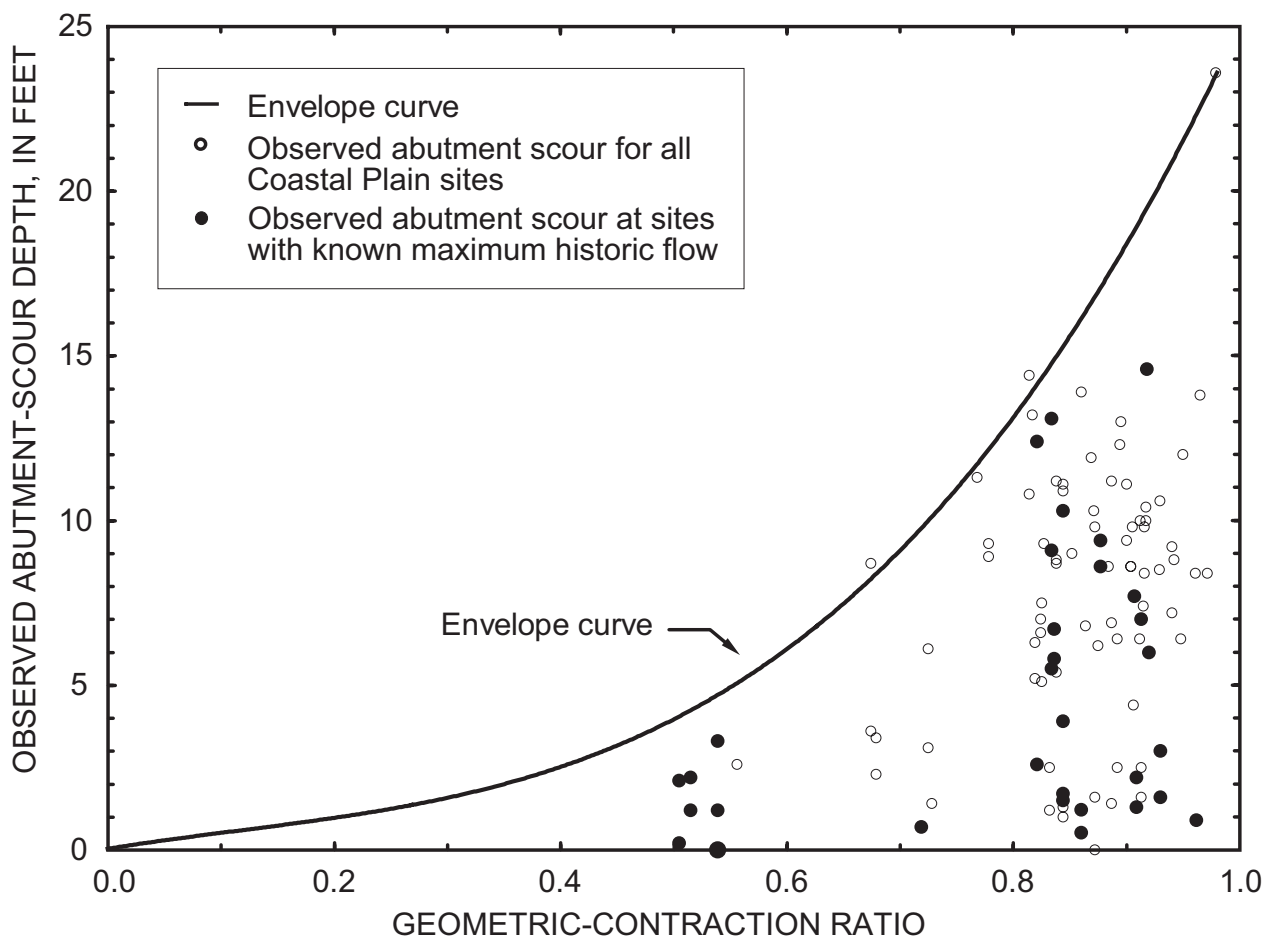

Figure 76. Relation of observed clear-water abutment-scour depth and the 100-year-flow geometric-contraction ratio identifying sites with known maximum historic flows in the Coastal Plain of South Carolina. 


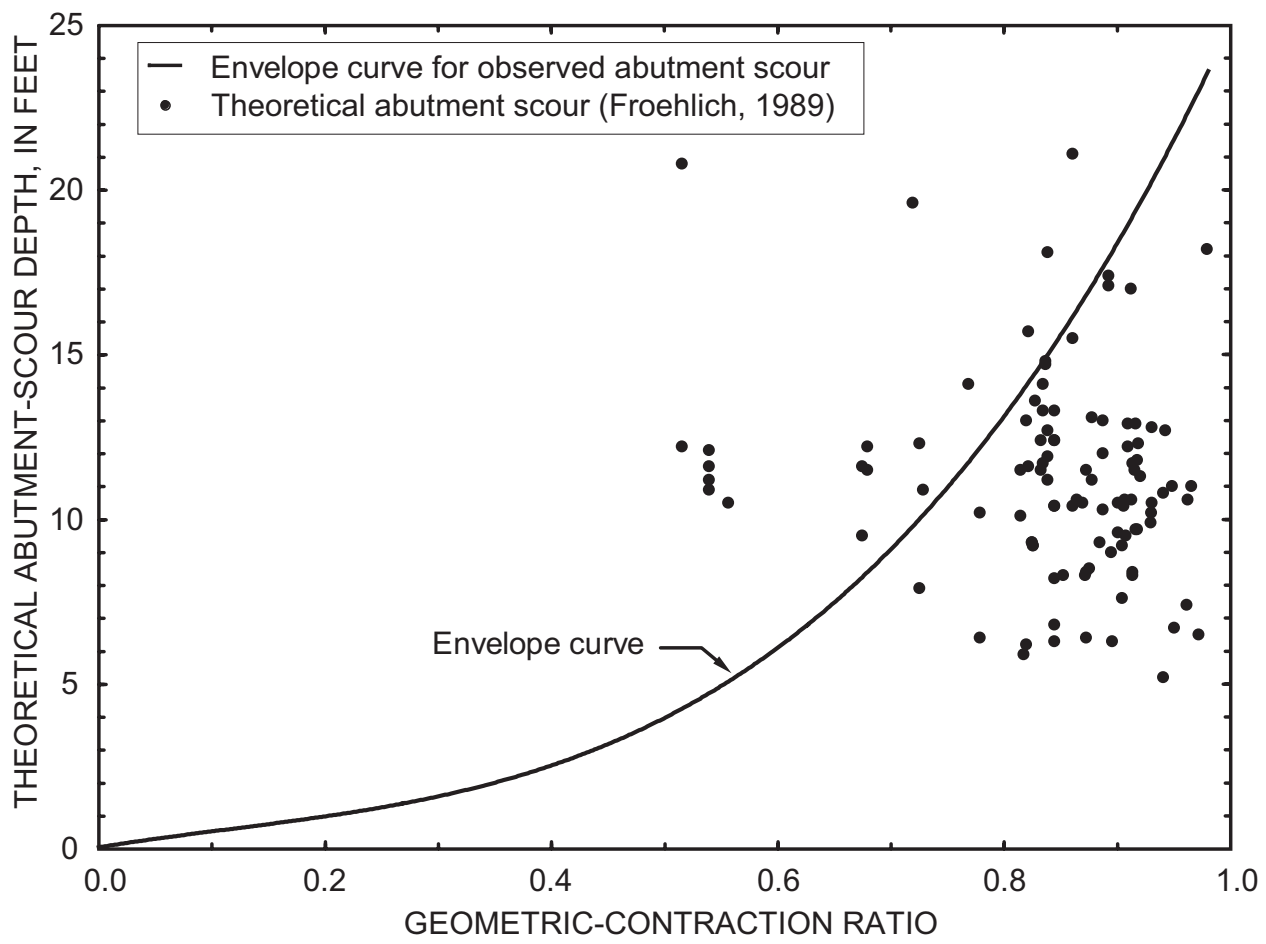

Figure 77. Relation of theoretical 100-year-flow abutment-scour depth and the 100-yearflow geometric-contraction ratio compared with the envelope of observed abutment scour in the Coastal Plain of South Carolina. (Theoretical abutment scour calculated with the Froehlich (1989) equation.)

geometric-contraction ratio envelope. For geometriccontraction ratios of 0.75 or less, 15 of the 16 theoretical values exceed the envelope, indicating that this part of the envelope may provide better estimates of abutment scour than the Froehlich equation. For ratios greater than $0.75,89$ of the 93 theoretical values fall below the envelope, indicating that this part of the envelope may overpredict scour depths. As mentioned previously, this overprediction can be attributed to the dimensionless character of the geometric-contraction ratio that obscures the effect of embankment length and will be discussed in more detail in the report section, "Selecting the Appropriate Abutment-Scour Depth Envelope."

As with the embankment-length envelope, most of the theoretical values are within the geometriccontraction ratio envelope, indicating that the Froehlich equation may often provide reasonable results in this region of South Carolina. As previously discussed, however, the Froehlich equation can occasionally underpredict observed scour (fig. 71A), making the envelope a preferable method for assessing potential abutment-scour depths in the Coastal Plain.

\section{Bridges 240 Feet or Less in Length}

As described previously, bridges approximately $240 \mathrm{ft}$ or less in length, tend to form a large, single scour hole (fig. 69) rather than separate left and right abutment-scour holes (fig. 70). This phenomenon appears to be caused by the overlap of turbulent and curvilinear flow coming from the left and right abutments. Because turbulent and curvilinear flows are typically associated with abutment scour, scour holes at these sites were classified as abutment scour. To associate these large, single scour holes with a particular abutment, the longer of the left or right embankment was used in the development of the embankment-length envelope curve. Figure 78A identifies the large, single scour holes at bridges $240 \mathrm{ft}$ or less in length, in relation to the embankmentlength envelope for the Coastal Plain. (Figure 78B is similar to figure 78A with the horizontal scale truncated to 2,000 $\mathrm{ft}$ to provide more detail for smaller embankment lengths.) For embankment lengths of $750 \mathrm{ft}$ or less, these sites appear to dominate the upper bound of the envelope, indicating that the single scour holes are generally deeper than separate left and (or) right abutment-scour holes at longer bridges. Comparing the 
A.

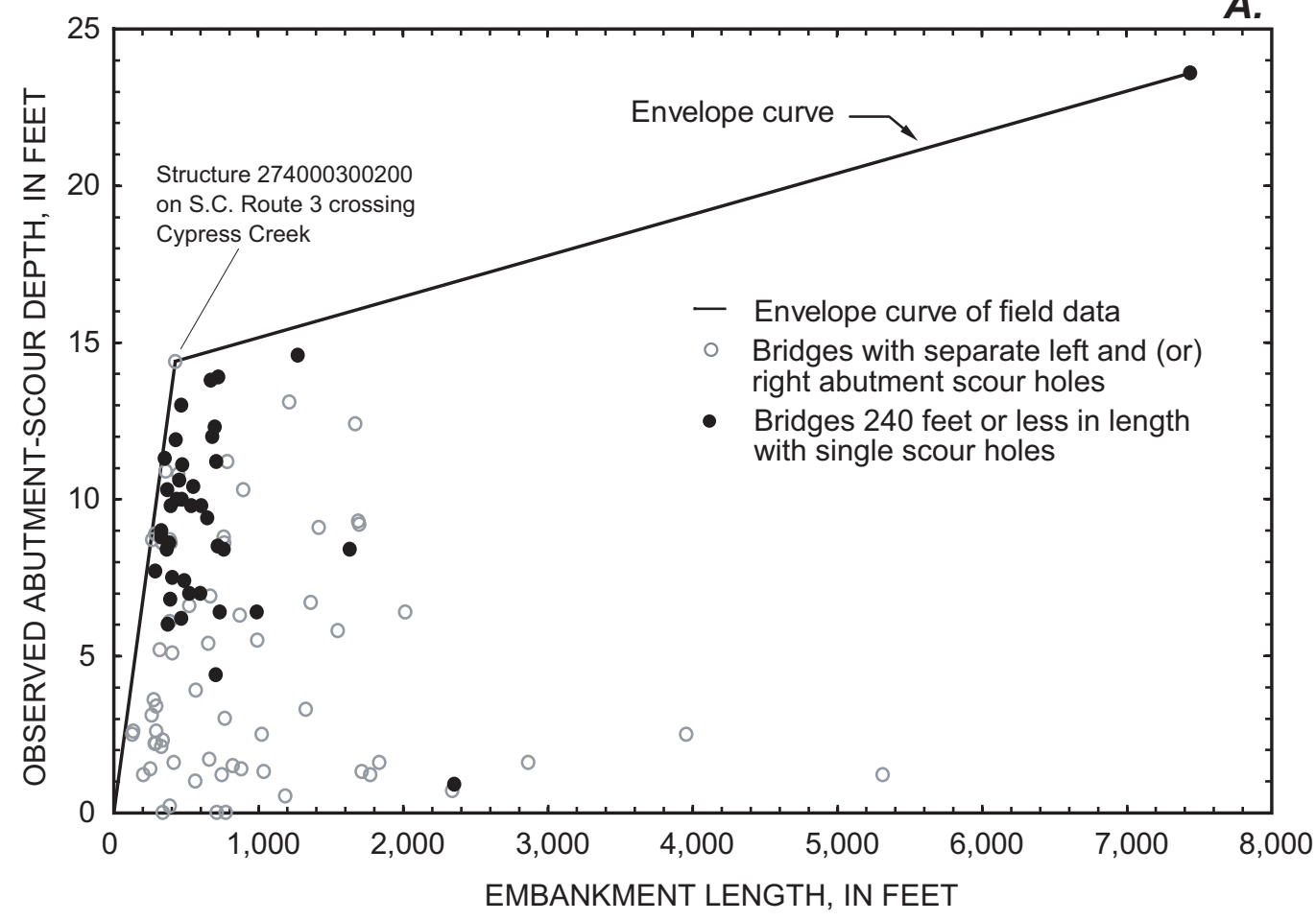

B.

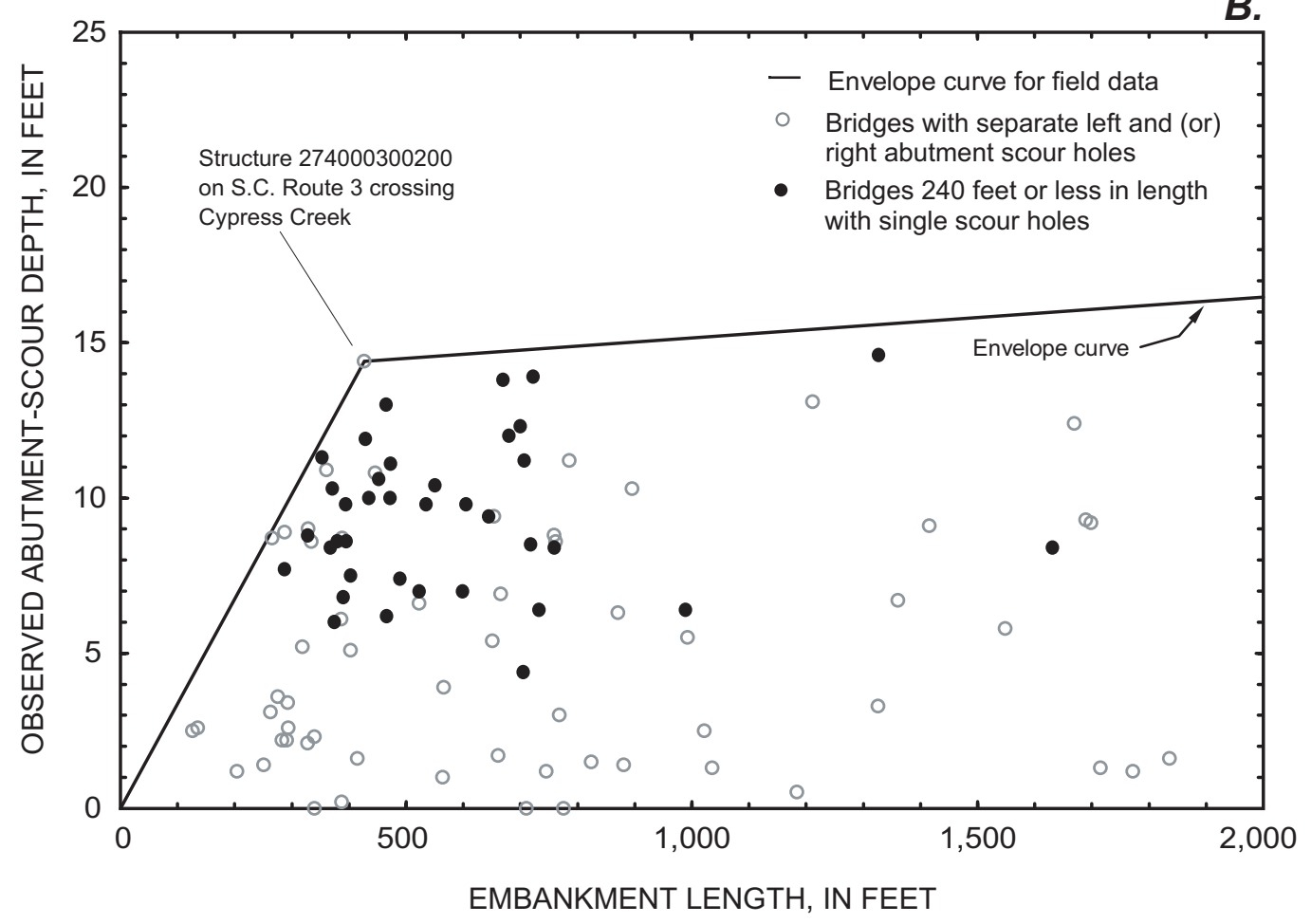

Figure 78. Relation of observed clear-water abutment-scour depth and the 100-year-flow embankment length identifying sites with bridge lengths of 240 feet or less and single scour holes in the Coastal Plain of South Carolina with a (A) complete horizontal axis and a (B) truncated horizontal axis. 
upper limit of scour depth at separate left and (or) right abutment-scour holes with the single scour holes indicates that the single scour holes can be about 3 to $4 \mathrm{ft}$ deeper (fig. 78). The one exception is Structure 274000300200 on S.C. Route 3 crossing Cypress Creek in Jasper County (reference number 81, app. B and fig. 1), which is located at the apex of the envelope (fig. 78). This bridge is $210 \mathrm{ft}$ in length and could be classified as a short bridge, but individual left and right abutmentscour holes were observed at this site. Excluding Cypress Creek, it may be possible to develop a separate envelope that encompasses separate left and right abutment-scour holes that are typically associated with longer bridges. Because of limited data, however, it was considered more prudent to develop one envelope based on all of the data.

When assessing abutment scour at shorter bridges in the Coastal Plain, it should be kept in mind that these sites tend to have larger scour depths than comparable sites with longer bridges. Using a bridge length of $240 \mathrm{ft}$ as the breakpoint between shorter bridges with single scour holes and longer bridges with separate left and right abutment-scour holes should be viewed as an approximate region of transition rather than an absolute value. When applying the abutment-scour envelope curves to shorter bridges, judgment should be used to ensure that the conditions at the site of interest are comparable to the sites included in this study.

\section{Floodplain Land Cover as an Indicator of Potential Scour}

As with the Piedmont, the most commonly observed land cover for floodplains in the Coastal Plain of South Carolina is forest. In the Piedmont, lowered flow resistance from deforestation was observed at a number of bridges and deeper scour holes commonly existed at these sites. In the Coastal Plain, only one site with a deep scour hole could be associated with deforestation: Interstate 95 overflow bridge crossing the Pee Dee River floodplain in Florence County. This site had the deepest observed scour in this study, $23.6 \mathrm{ft}$. Investigations of historic aerial photographs by the SCDOT indicated that significant deforestation occurred on the upstream floodplain after construction of this bridge (William Hulbert, South Carolina Department of Transportation, oral commun., 1996). Therefore, it is likely that deforestation had a significant influence in the development of this scour hole. With only one observation in the Coastal Plain associated with deforestation, it is inappropriate to draw general conclusions about the effect of deforestation on scour in this region, but the one observation is consistent with the pattern observed in the Piedmont.

\section{EFFECT OF UPSTREAM CHANNEL ALIGNMENT ON ABUTMENT SCOUR}

Channel bends can present a unique problem at bridges because approaching flow distributions at flood stage can be significantly altered when flows leave a channel and enter a floodplain at a channel bend. When channel bends occur upstream, near a bridge, concentrated channel flows can be directed to a section of a bridge opening that would not typically experience this magnitude of flow if the channel were straight. Under these conditions, large scour holes can develop even when embankment lengths and geometric-contraction ratios are relatively small. Two sites of this nature were noted during field investigations: Structure 304007200500 on S.C. Route 72 crossing Little River in Laurens County and Structure 264000920500 on S.C. Route 9 crossing the Waccamaw River in Horry County. (Data from the S.C. Route 9 bridge were not included in the analysis for this report, but are presented here for information purposes.)

The Little River in Laurens County has several sharp bends upstream from the bridge on S.C. Route 72 (fig. 79). During flood conditions, concentrated flows leave the main channel and enter the right abutment area creating a deep scour hole (13.3 ft) that is associated with an embankment length of $52 \mathrm{ft}$. This is significantly outside the embankment-length envelope for the Piedmont (fig. 60). The USGS 7.5-minute series topographic map (U.S. Geological Survey, 1971) and aerial photographs of this site indicate that the Little River does meander; however, the severe bends near the bridge cannot be readily identified on the map or photograph. Field visits quickly identified these bends and the associated scour problem, underscoring the importance of site visits to help assess scour at bridges.

The Waccamaw River in Horry County has a sharp meander bend just upstream from the bridge on S.C. Route 9 (fig. 80). During the 1999 flood, flow measurements at this bridge (USGS gaging station 02110500, Waccamaw River at Longs, S.C.) exceeded the 100-year flow magnitude. During flood conditions, concentrated flows apparently overtopped the main channel and entered the left abutment area creating a scour hole that was approximately $15 \mathrm{ft}$ deep and $150 \mathrm{ft}$ wide (fig. 81). The 


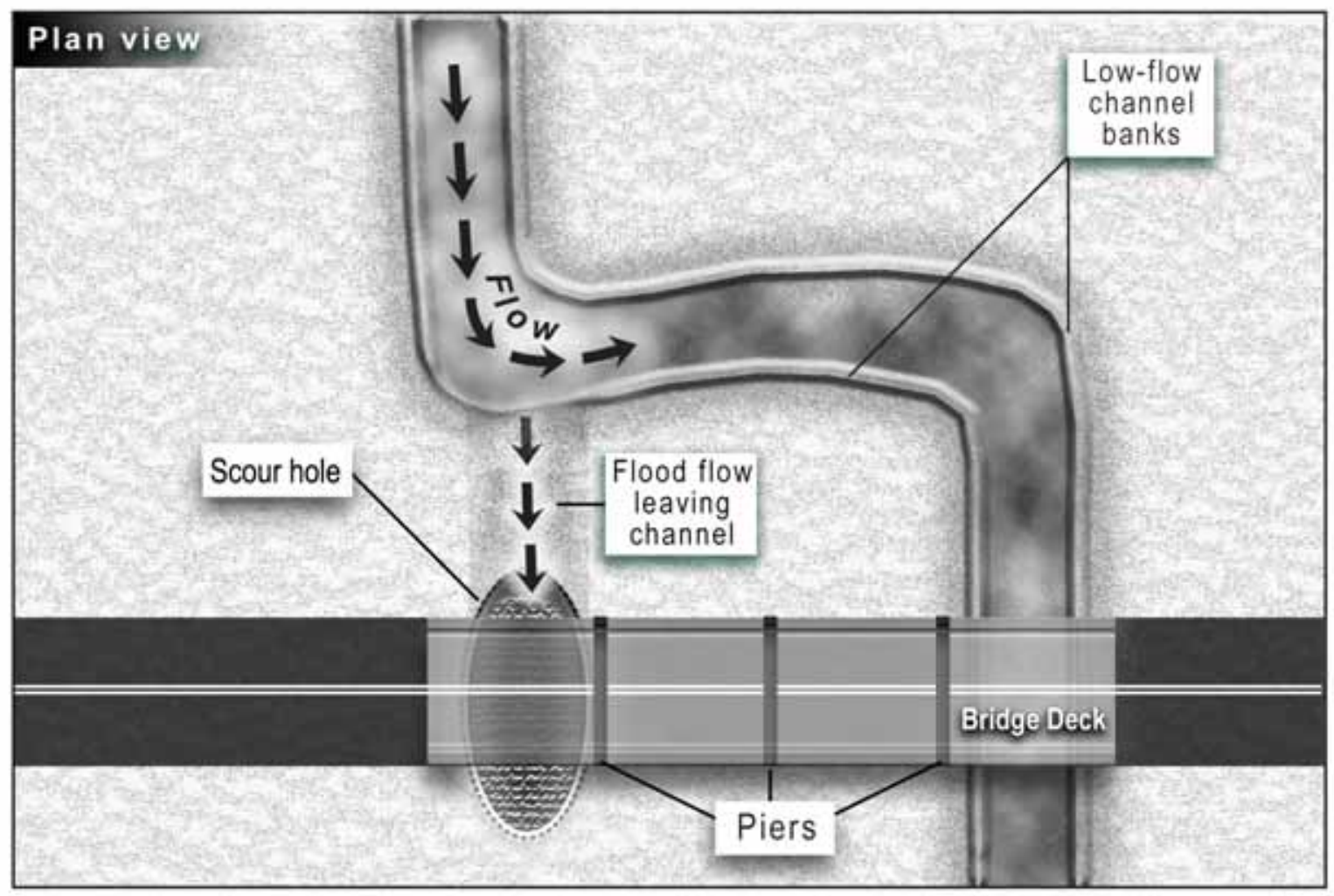

Figure 79. Plan view of channel bends and resulting scour hole at Structure 304007200500 on S.C. Route 72, crossing the Little River in Laurens County, South Carolina. (Note: Not to scale.)

embankment associated with this scour hole is approximately $800 \mathrm{ft}$ long. The observed scour depth is slightly outside the embankment-length envelope for the Coastal Plain (fig. 72) and the scour-hole width is larger than those observed in this study. Because the Waccamaw River has a wide channel, the USGS 7.5-minute series topographic map (U.S. Geological Survey, 1990) and aerial photographs are useful tools for identifying this potential scour problem. Envelope curves developed in this report should not be used to assess scour at sites that have channel bends in the upstream reach near a bridge. Instead, one should review all available resources for the site of interest and use judgment to make a final decision on anticipated scour depths.

\section{GUIDANCE FOR ASSESSING ABUTMENT-SCOUR DEPTH USING THE ENVELOPE CURVES}

The envelope curves presented in figures 60, 63, 72 , and 75 can be useful tools for assessing abutmentscour depth at bridges in South Carolina. When using these envelope curves, one must select a reference surface, determine the scour depth using the appropriate abutment-scour envelope curve, and consider other scour components in the abutment region. Although these steps require judgment, some guidance for accomplishing these steps is presented in this section. 


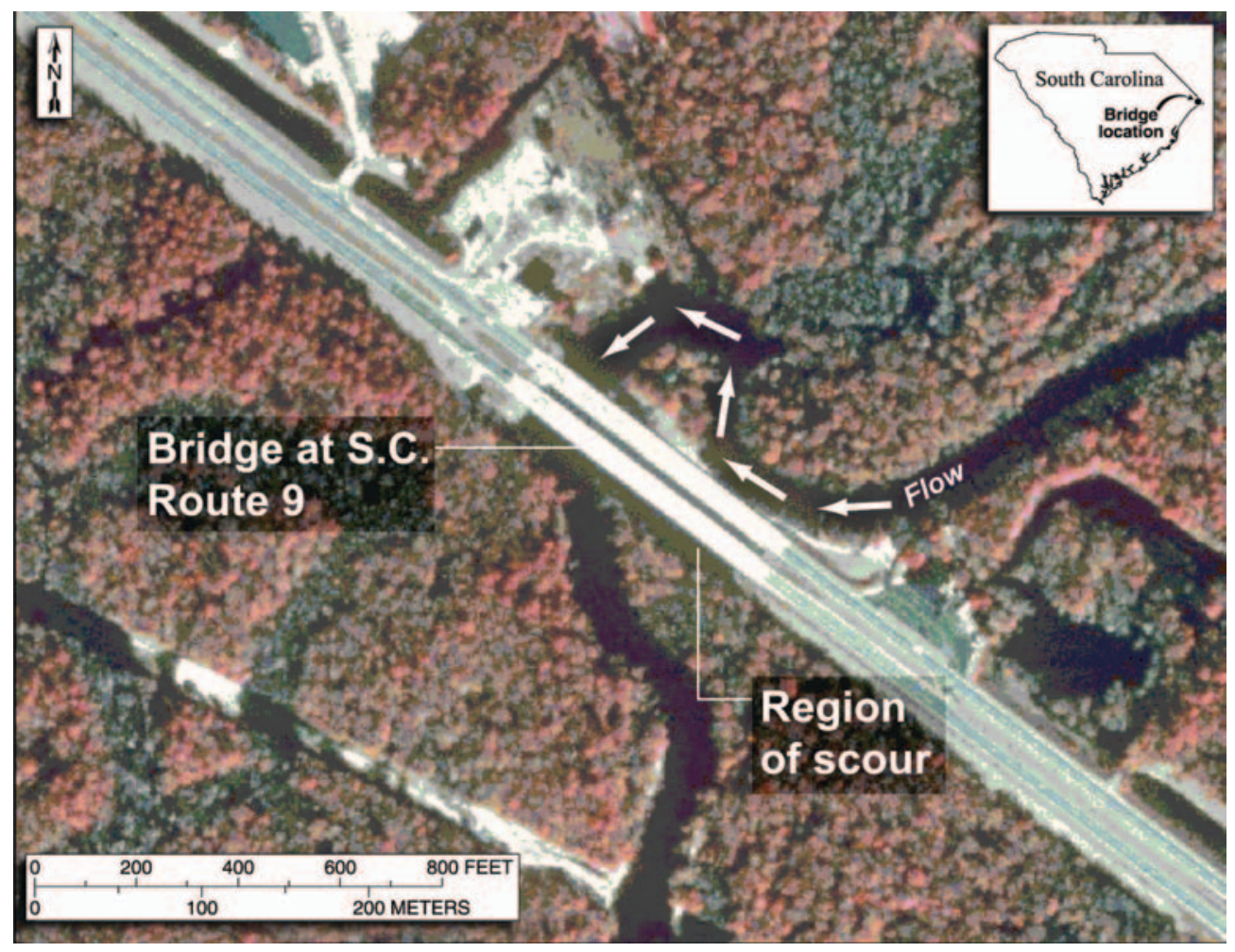

Figure 80. Severe meander on the Waccamaw River at Structure 264000920500 on S.C. Route 9 in Horry County, South Carolina. (Photograph from South Carolina DOQQ Archive, 1994.)

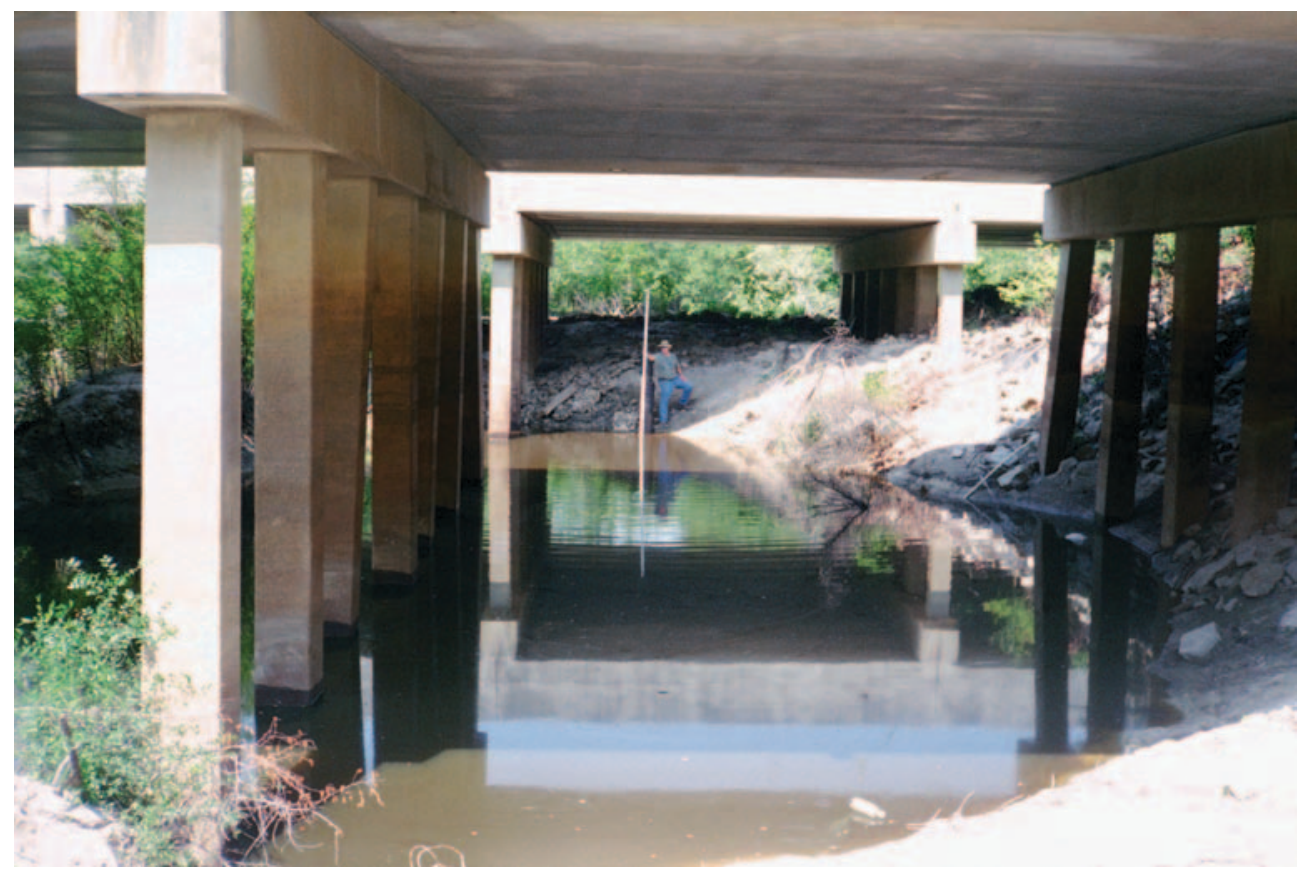

Figure 81. Scour hole at left abutment viewed from downstream at Structure 264000920500 on S.C. Route 9, crossing the Waccamaw River in Horry County, South Carolina. (Photograph by the South Carolina District, U.S. Geological Survey, June 2000.) 


\section{Selecting a Reference Surface for Abutment-Scour Depth}

The envelope curves presented in this report can be used to assess potential scour depths at bridge abutments. The scour depth, in turn, must be subtracted from the appropriate reference surface to determine the bottom elevation of the scour hole and the effect that the scour will have on bridge foundations. In this study, the average, undisturbed floodplain elevation in the abutment-scour region was used to determine abutment-scour depth; this reference surface should be used when assessing abutment scour with the envelope curves. The reference surface can be determined by reviewing floodplain elevations from SCDOT road and bridge plans, surveyed cross sections, and (or) site visit observations. In many cases, the floodplain in the region of the abutment is relatively flat, so estimating an average floodplain elevation in the region of anticipated scour is not a difficult task. However, there can be cases where the floodplain significantly slopes in the lateral and (or) longitudinal direction making the determination of a reference surface more difficult. In such cases, judgment must be applied, bearing in mind that lower reference-surface elevations will produce lower scour-hole elevations.

\section{Estimating the Embankment Length and the Geometric-Contraction Ratio}

The explanatory variables used in the abutmentscour depth envelope curves are the embankment length and the geometric-contraction ratio. The envelope curves can be sensitive to these explanatory variables; therefore, it is critical that these variables be accurately determined. When developing the envelope curves, the embankment length and the geometriccontraction ratio were determined using a flow model for the 100-year flow condition. When applying the envelope curves at specific sites, these variables also should be estimated for the 100-year flow at the site of interest. It also is recommended that topographic maps and road plans be used to verify embankment lengths and the geometric-contraction ratio. When discrepancies exist between these sources, judgment should be used to determine the most reasonable estimate of the explanatory variables.

\section{Selecting the Appropriate Abutment- Scour Depth Envelope}

When assessing abutment-scour depths using envelope curves presented in this report, one must select envelope curves for the appropriate physiographic region (Piedmont or Coastal Plain), and then use the embankment-length and the geometric-contraction-ratio envelope, for the selected region, to assess potential abutment-scour depth. These two envelope curves will often provide different estimates for the upper range of abutment-scour depth, so one must select the most appropriate depth. Application of these envelope curves to selected sites in South Carolina has shown that the geometric-contraction-ratio envelope, for both physiographic regions, will typically provide higher estimates of abutment-scour depth than the embankment-length envelope curves. At times, the scour-depth estimate from the geometric-contraction-ratio envelope is excessive. Excessive estimates can be attributed to the dimensionless nature of the geometric-contraction ratio and its inability to account for changes in embankment length. For example, a 100-ft-long bridge crossing a 500-ft-wide Piedmont floodplain has a geometric-contraction ratio of 0.8 . Similarly, a 200 -ft-long bridge crossing a 1,000-ftwide floodplain will have the same geometric-contraction ratio. If these bridges are symmetrically located on the floodplain, then the embankment lengths will be 200 and $400 \mathrm{ft}$, respectively. Using the geometric-contraction-ratio envelope curve (fig. 63) to estimate abutmentscour depth, the scour depth will be identical for both bridges. It is reasonable, however, to assume (with all other variables the same) that the bridge with the shorter embankments will have smaller scour depths than the bridge with longer embankments. Another example of where excessive estimates of abutment scour depth may occur, is at sites having eccentric bridge crossings where one embankment is substantially shorter in length.

In such cases, the geometric-contraction-ratio envelope will give identical scour depths at both abutments. However, with other variables remaining constant, it is reasonable to assume that scour depths will be less at the shorter embankment of an eccentric bridge crossing. To avoid overestimates of the range for abutment-scour depth, it may be reasonable to use the embankmentlength envelope curve as the primary tool for estimating abutment-scour depth in the Piedmont and Coastal Plain of South Carolina. If a conservative estimate of the range of abutment-scour depth is needed, then the larger scour depth obtained from the geometric-contraction ratio or embankment-length envelope curve may be more appropriate. Special consideration must be given to 
the selection of the appropriate envelope curve when dealing with multiple-bridge openings, and a discussion of assessing abutment-scour depth at single-and multiple-bridge openings follows.

\section{Single-Bridge Openings}

In the Piedmont, 63 of the 65 bridges surveyed in this study were single-bridge openings. All of these data, with the exception of Structure 304007200500 at S.C. Route 72 crossing Little River in Laurens County (reference number 89, appendix B and fig. 1), fall within the embankment-length and geometric-contraction-ratio envelope curves for the Piedmont region of South Carolina (figs. 60 and 63). Therefore, if a singlebridge opening in the Piedmont has site conditions similar to bridges included in this study, it is appropriate to use either envelope curve to estimate the range of anticipated abutment-scour depth.

In the Coastal Plain, 50 of the 81 bridges surveyed in this study were single-bridge openings. All of these data fall within the embankment-length and geometric-contraction-ratio envelope curves for the Coastal Plain region of South Carolina (figs. 72 and 75). As with the Piedmont, if a single-bridge opening in the Coastal Plain has site conditions similar to bridges included in this study, it is appropriate to use either envelope curve to estimate the range of anticipated abutment-scour depth. As previously discussed, it may be reasonable to use the embankment-length envelope curve as the primary tool for estimating abutment-scour depth at single-bridge openings in the Piedmont and Coastal Plain of South Carolina. If a conservative estimate of the range of abutment-scour depth is needed, then the larger scour depth obtained from the geometric-contraction-ratio or embankmentlength envelope curve may be more appropriate.

When assessing Coastal Plain abutment-scour depths at single-bridge openings crossing swamps with poorly defined low-flow channels, with bridge lengths approximately $240 \mathrm{ft}$ or less, the longest of the left or right embankment lengths should be used in conjunction with the embankment-length envelope curve (fig. 72). The geometric-contraction-ratio envelope (fig. 75) also may be used to assess abutment-scour depth at these bridges, bearing in mind that this estimate may be high for shorter embankment lengths. The estimated scour depth will be assumed to represent the depth of the large, single scour hole that will likely extend from abutment toe to abutment toe.

\section{Multiple-Bridge Openings}

Floodplain widths in the Piedmont are relatively narrow and, therefore, multiple-bridge openings are uncommon. Two of the 65 Piedmont bridges surveyed in this study were associated with multiple-bridge openings: Structure 237004000100 on Road S-40 crossing South Saluda River in Greenville County and Structure 304007201200 on S.C. Route 72 crossing Duncan Creek in Laurens County (reference numbers 63 and 90, respectively, appendix B and fig. 6.) These crossings include main-channel bridges and floodplain relief structures. The two bridges of interest are floodplain relief structures with bridge lengths of 60 and $100 \mathrm{ft}$, respectively. Because of the short bridge lengths, large, single scour holes developed at these sites similar to scour holes at short bridges in the Coastal Plain. (For more details on this scour-hole pattern refer to the "Bridge Lengths of 240 Feet or Less" section under "Abutment Scour in the Coastal Plain.") Figure 82 shows the Piedmont embankment-length envelope, previously described, with identification of data from the two multiple-bridge openings. Observed scour at Duncan Creek falls outside of the envelope curve. This anomaly is possibly caused by the irregular distribution of flow that commonly occurs at a multiple-bridge site. In addition, stagnation points for flow between multiple-bridges, as estimated by the simplified routine in the WSPRO (Shearman, 1990) model, may be in error. Any error in this estimate will provide improper estimates of the embankment lengths. In contrast, all data (single and multiple bridges) fall near or within the Piedmont geometric-contraction-ratio envelope curves (fig. 83). Therefore, when estimating abutment scour at multiplebridge openings in the Piedmont, it appears reasonable to use the geometric-contraction-ratio envelope (fig. 63) rather than the embankment-length envelope (fig. 60).

In contrast to the Piedmont, floodplains in the Coastal Plain are typically flat and wide and often have multiple-bridge openings. Thirty-one of the 81 Coastal Plain bridges surveyed in this study were associated with multiple-bridge openings. When developing the Coastal Plain embankment-length envelope curve, 4 of the 48 multiple-bridge observations of abutment scour fell outside of the envelope (fig. 84). As with the Piedmont, this anomaly is possibly caused by complex flow patterns and errors associated with the WSPRO (Shearman, 1990) model. The four multiple bridges in the Coastal Plain that fall outside of the embankmentlength envelope have embankment lengths of $193 \mathrm{ft}$ or less. In contrast, all data (single and multiple bridges) 


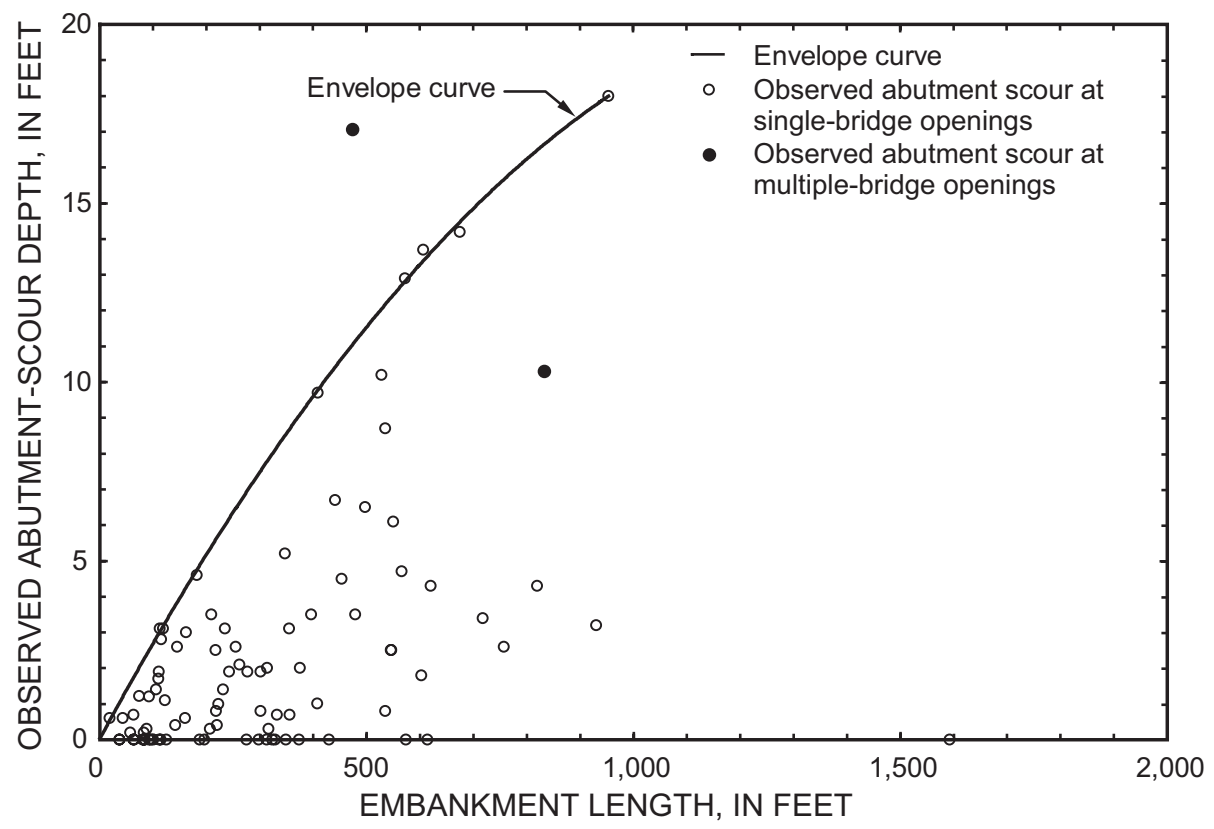

Figure 82. Relation of observed clear-water abutment-scour depth and the 100-yearflow embankment length with the identification of multiple-bridge openings for the Piedmont of South Carolina.

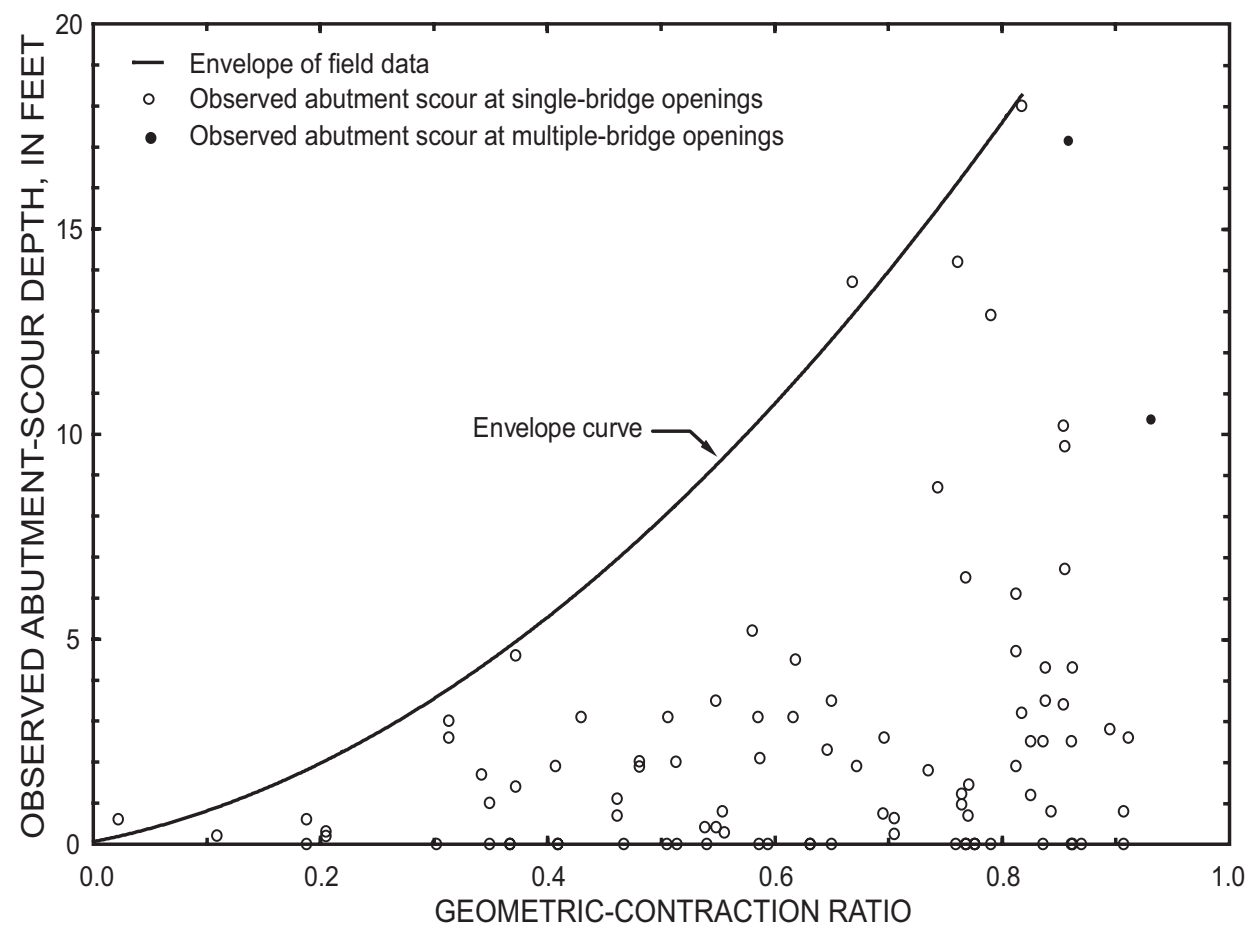

Figure 83. Relation of observed clear-water abutment-scour depth and 100-year-flow geometric-contraction ratio with the identification of multiple-bridge openings for the Piedmont of South Carolina. 


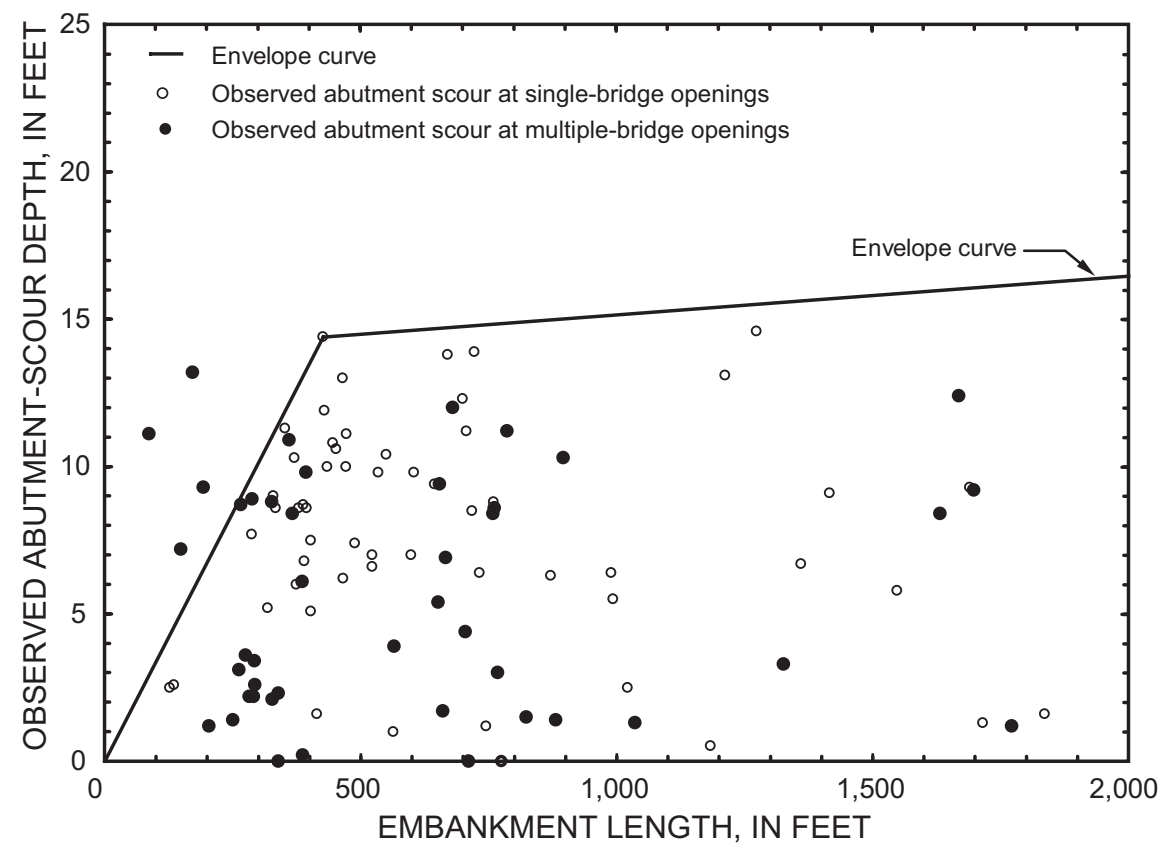

Figure 84. Relation of observed clear-water abutment-scour depth and the 100-year-flow embankment length with the identification of multiple-bridge openings in the Coastal Plain of South Carolina.

fall near or within the Coastal Plain geometric-contraction-ratio envelope (fig. 85). Therefore, if a multiplebridge opening in the Coastal Plain has site conditions similar to bridges included in this study, it is appropriate to use the geometric-contraction-ratio envelope (fig. 75) rather than the embankment-length envelope (fig. 72) to estimate the range of anticipated abutment-scour depth. There are some cases, however, where the use of the embankment-length envelope for multiple-bridge openings in the Coastal Plain is appropriate and these cases are described in the following paragraphs.

As previously discussed, the geometric-contraction-ratio envelope tends to overpredict the range of scour depth. To minimize this effect when assessing multiple-bridge openings in the Coastal Plain, the following steps should be followed. Examination of the embankment-length envelope curve for the Coastal Plain (fig. 72) shows that the envelope has a sharp break in slope at an embankment length of $425 \mathrm{ft}$. Estimates of the upper limit for the range of abutmentscour depths will be sensitive for embankment lengths less than $425 \mathrm{ft}$, and relatively insensitive for embankment lengths greater than $425 \mathrm{ft}$. Because observed scour at all Coastal Plain multiple-bridge openings with embankment lengths greater than $425 \mathrm{ft}$ fall within the embankment-length envelope (fig. 84), it is reasonable to assume that the embankment-length envelope would be applicable to Coastal Plain multiple-bridge openings with embankment lengths exceeding $425 \mathrm{ft}$. In the case of multiple-bridge openings with embankment lengths less than $425 \mathrm{ft}$, the geometriccontraction-ratio envelope (fig. 75) may be used.

As with single-bridge openings in the Coastal Plain, field data show that multiple-bridge openings crossing swamps with poorly defined low-flow channels, with bridge lengths of approximately $240 \mathrm{ft}$ or less, tend to form one large scour hole rather than separate left and right abutment-scour holes. The width of the single scour hole commonly encompasses the entire bridge opening extending from one abutment toe to the other. To estimate scour at such bridges, the following approach may be reasonable. Select the longest of the left and right embankment lengths. If the longest embankment length is $<425 \mathrm{ft}$, then use the geometriccontraction-ratio envelope to estimate the abutmentscour depth. If the length is $\geq 425 \mathrm{ft}$, then use the embankment-length envelope to estimate the range of abutment-scour depth. The estimated scour depth is assumed to represent the depth of the large, single scour hole that will likely extend from abutment toe to abutment toe. 


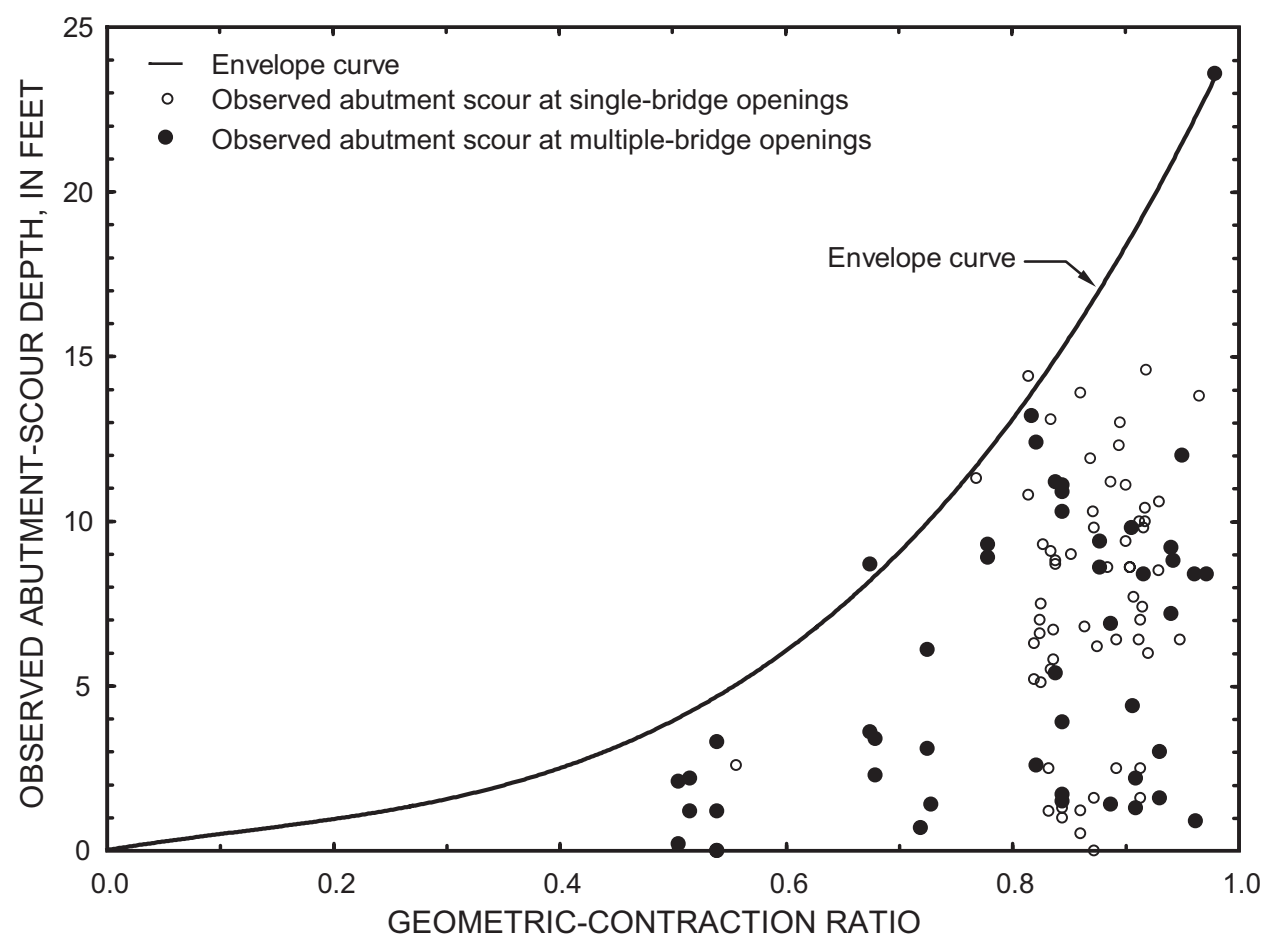

Figure 85. Relation of observed clear-water abutment-scour depth and the 100-yearflow geometric-contraction ratio with the identification of multiple-bridge openings in the Coastal Plain of South Carolina.

\section{Contraction and Pier Scour within the Abutment-Scour Area}

As previously discussed in the report section, "Techniques for the Collection and Interpretation of Field Data," contraction scour should not be considered a contributing component to total scour in the abutment region. Therefore, when using the envelope curves to assess total scour depth at abutments, no adjustment for contraction scour in the abutment region is required.

In the case of pier scour, consideration must be given to the impact that piers in the abutment region may have on total scour. As previously discussed in the report section, "Techniques for the Collection and Interpretation of Field Data," measured scour at deeper abutment-scour holes represents total scour, including the impact of pier scour, if a pier was located within the scour hole. The assumption also was made that piers or multiple-column bents located at the bottom of the scour hole produced the largest effect on total scour. Figure 86 shows the previously developed envelope curves for the relation of embankment length and abutment-scour depth for the Coastal Plain and
Piedmont, identifying sites where the low point of the abutment-scour hole coincides with a pier or multiplecolumn bent. The figure shows many such sites falling on or near the envelope curves, indicating that the envelope curves, include the worst-case impact of local pier scour on total scour at abutments.

When examining more closely the sites that have piers at the low point of the abutment-scour hole, the supporting substructures for all but one of the sites were found to be multiple-column bents that range in width from 1 to $2.3 \mathrm{ft}$ with little or no skew. Based on this observation, it is reasonable to assume that the envelope curves include the impact of such bents on total scour in the abutment region and no adjustment for pier scour is required. When the column and pier width exceeds $2.3 \mathrm{ft}$, judgment should be used to determine if the results of the abutment-scour envelope curves should be adjusted to account for the effects of the wider piers. Judgment also should be used if the effects of debris and (or) severe skews must be considered.

The above guidance must be slightly modified for abutment-scour holes of approximately $5 \mathrm{ft}$ or less 
A.

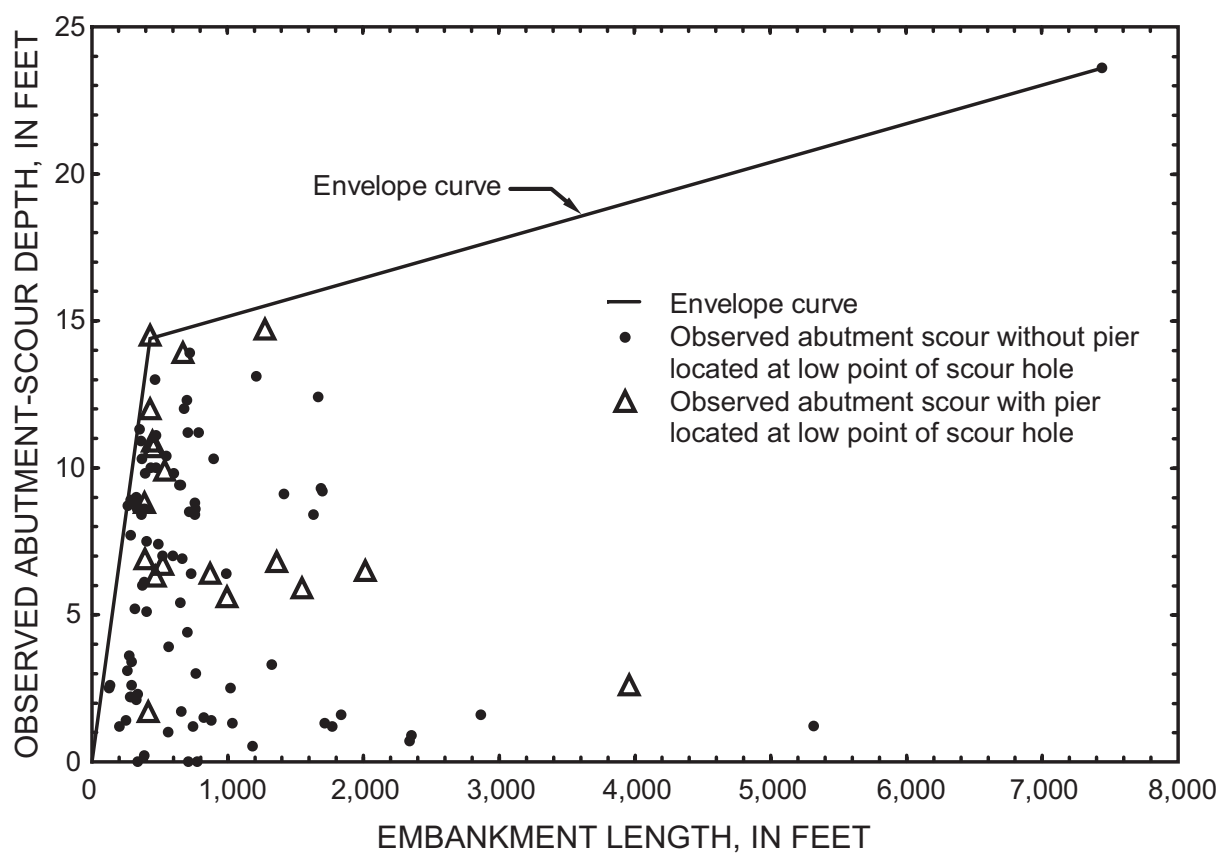

B.

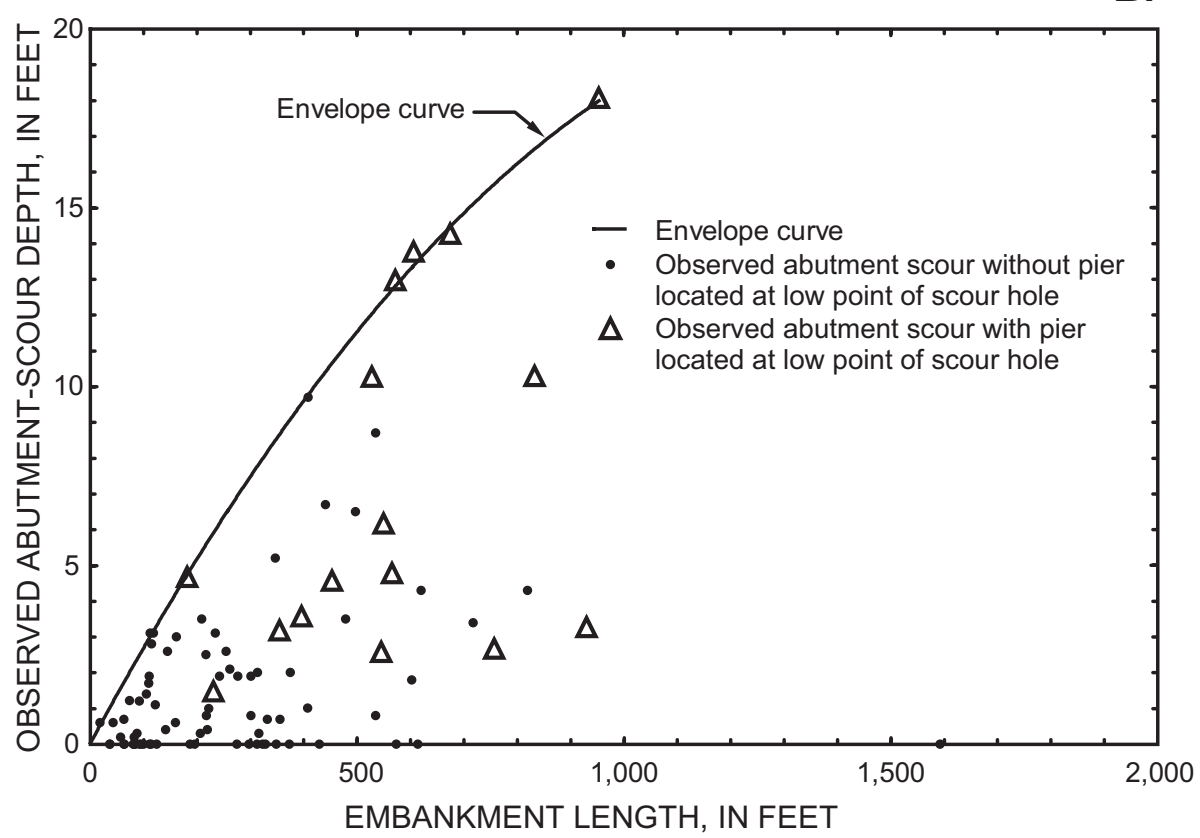

Figure 86. Relation of observed clear-water abutment-scour depth and the 100-yearflow embankment length identifying sites with a pier or pile bent located at the low point of the scour hole for the (A) Coastal Plain and (B) Piedmont of South Carolina. 
in the Piedmont. These scour holes were typically dry and shallow, making it possible to distinguish the region of pier scour from the region of abutment scour. When collecting data at these sites, scour around the pier generally was not included in the measurement. Therefore, when the range of abutment-scour depth in the Piedmont is estimated to be $5 \mathrm{ft}$ or less with the envelope curve, judgment should be used to account for the effect of pier scour within the abutment region.

\section{Limitations of the Abutment-Scour Depth Envelope Curves}

When using the abutment-scour depth envelope curves for assessing clear-water abutment scour in South Carolina, the potential error and limitations of these curves should be kept in mind. The abutmentscour depth envelope curves were developed using modeled hydraulic data that only estimate the true hydraulic conditions that may have created the observed scour. It is probable that errors exist within the hydraulic estimates introducing error within the envelope curves. This error is partially mitigated by the large number of observations, but the actual error and the degree of mitigation is unknown. Although the 209 observations of abutment scour in this study are considered a statistically large data sample, this sample may not encompass the upper range of potential scour depths in South Carolina. Therefore, abutment-scour depths in South Carolina could possibly exceed the envelope curves developed in this study. As a result, it may be prudent to include a safety factor when using the envelope curves to assess scour.

When assessing abutment scour at a bridge in South Carolina, it is important that site characteristics at that bridge are similar to the characteristics of the sites used to develop the envelope curves. Site conditions at a bridge of interest should be compared with the range of parameters included in this study (tables 10 and 13, and figs. 2, 3, and 68) to help assess the appropriateness of using the envelope curves. Also, the bridge-scour database, included with this report, can be used to review studied sites to gain insights about potential scour at unstudied sites. Limits for embankment length and the geometric-contraction ratio have been defined for each envelope and care should be given to remain within those limits. When site characteristics are significantly different from the sites used in this study, other methods for assessing abutmentscour depth should be considered.
The abutment-scour depth envelope curves were developed using hydraulic data estimated with the hypothetical 100-year flow. Although it is unlikely that all study sites experienced this flow magnitude, there is evidence to suggest that many sites experienced flows equaling or exceeding 70 percent of this flow magnitude. Therefore, estimates of abutment-scour depth obtained from the envelope curves should represent scour that may occur at such flow magnitudes. The envelope curves should not be used to assess scour for extreme events, such as the 500-year flow.

An additional scour problem that frequently occurs in South Carolina is the washout of road embankments. Typically, washout occurs at smaller bridges that create a large contraction of flow. The magnitude of this problem is seen from bridge failure statistics from the October 1990 flood. This event caused 80 bridges to fail in South Carolina with 79 of these failures attributed to embankment washout (Hurley, 1996). Data collected in this study did not include failure from embankment washout and, therefore, envelope curves in this report cannot be used to assess this type of abutment scour.

Although the envelope curves presented in this report can serve as a valuable tool in assessing abutment-scour depths in South Carolina, the potential errors and limitations restrict their use. Therefore, the envelope curves should not be relied upon as the only tool for assessing abutment scour. To best assess anticipated scour, one should compile and study the available information for a given site and then bring sound engineering principals to bear on the final estimate of anticipated abutment-scour depth.

\section{GUIDANCE FOR ASSESSING ABUTMENT- SCOUR HOLE LOCATION, WIDTH, AND SHAPE}

In addition to assessing abutment-scour depth at a given site, it is important to consider the scour-hole geometry and location within the bridge cross section. Estimating scour-hole characteristics is critical for assessing the impact of scour on the various bridge supports (abutments, piers, and pile bents). This section discusses and gives guidance for assessing the location, width, and shape of an abutment-scour hole. 


\section{Lateral Reference for Scour Hole}

In general, the edge of an abutment-scour hole was observed to be most commonly located near the toe of the abutment (fig. 87). Figure 88 shows the relation of observed abutment-scour depth and distance from the top edge of the scour-hole bank to the toe of the abutment. In the case of left abutments, the distance is measured from the left abutment toe to the top left bank of the scour hole created by the left abutment. In the case of right abutments, the distance is measured from the right abutment toe to the top right bank of the scour hole created by the right abutment.

The plot in figure 88 includes only 112 of the 209 observations of abutment scour. A total of 97 observations were excluded because: (1) there was no observed scour (33 sites); (2) the scour hole occurred at a short bridge where a large, single scour hole developed rather than two separate scour holes (43 sites); (3) the low point of the scour hole was located at some distance upstream or downstream from the bridge, making it difficult to reference to the abutment toe (13 sites); and (4) the data were incomplete (8 sites).

The scour-hole banks were contiguous with abutment toes for 68 percent of the observations. The banks were 1 to $15 \mathrm{ft}$ from the toe for 22 percent of the observations. The remaining observations that were located more than $15 \mathrm{ft}$ from the abutment toe can be associated with shallow scour depths ( $4.3 \mathrm{ft}$ or less) that typically would not threaten bridge foundations. Although field data indicate variation in the lateral location of the abutment-scour hole, the abutment toe is the dominant location and appears to be a reasonable reference for locating the edge of the scour hole. Error in the prediction of the lateral location of deep scour holes could result in underestimates of scour at certain piers. This error can be minimized by using a conservative estimate of scour-hole top width as discussed in the following section.

\section{Scour-Hole Top Width}

Using the abutment toe as a reference location for the bank of the abutment-scour hole, the lateral extent of the area affected by scour can be assessed by estimating the scour-hole top width. Figure 89 shows the relation of observed scour-hole top widths and observed scour depths for two site conditions. Figure 89A represents the envelope for longer bridges in the Piedmont and Coastal Plain where two individual abutment-scour holes typically develop. Short bridges (approximately $240 \mathrm{ft}$ or less) located on swamps or serving as floodplain relief structures, tend to develop single-scour holes and are represented in figure 89B.

The scatter in the depth-to-width ratio of the observed scour is large, making estimates of scour-hole top width highly variable. Using the envelope curves in figure 89 , a conservative estimate of top width can be obtained. These estimates could be unreasonable under some site conditions. At Piedmont sites where the overbank width (at setback abutments) is less than the estimated abutment-scour-hole top width, it may be reasonable to limit the estimated scour-hole top width to the width of the overbank. At relatively short bridges, where the left and right scour-hole top widths overlap or the estimated top width exceeds the toe-totoe width between the left and right abutments, it may be reasonable to select the deepest of the left and right abutment-scour-hole depths as an estimate of the abutment-scour depth at the bridge and then limit the estimated scour-hole top width to the toe-to-toe width.

\section{Scour-Hole Longitudinal Location}

The upstream-to-downstream longitudinal location for the low point of the scour hole is highly variable. Figure 90 shows the relation of the 100-year-flow top width at the bridge and the longitudinal location of the scour-hole low point for the Piedmont and Coastal Plain. For the shallow scour depths (4.5 ft or less) in the clayey soils of the Piedmont, the low point of the scour hole is typically along the centerline of the roadway directly under the bridge (fig. 90A). However, the deeper scour holes of the Piedmont can have longitudinal locations that extend beyond the limits of the bridge. For the Coastal Plain sites, the longitudinal location of the scour hole can vary significantly for 100-year-flow bridge top widths of $300 \mathrm{ft}$ or less, (fig. 90B). However, beyond $300 \mathrm{ft}$, the longitudinal location falls close to the roadway centerline directly under the bridge. Although data for the deeper scour holes in the Piedmont are not as abundant as data in the Coastal Plain, a similar trend can be observed.

Figure 90 shows that, for bridges with 100-yearflow top widths approximately $300 \mathrm{ft}$ or less, the low point of the scour hole might be located outside of the bridge limits. In some cases, the low point of the scour hole was largely removed from the bridge so as to not significantly threaten bridge foundations (figs. 91 and 92). Interaction of turbulent flow coming from the left and right abutments likely causes instabilities in the 


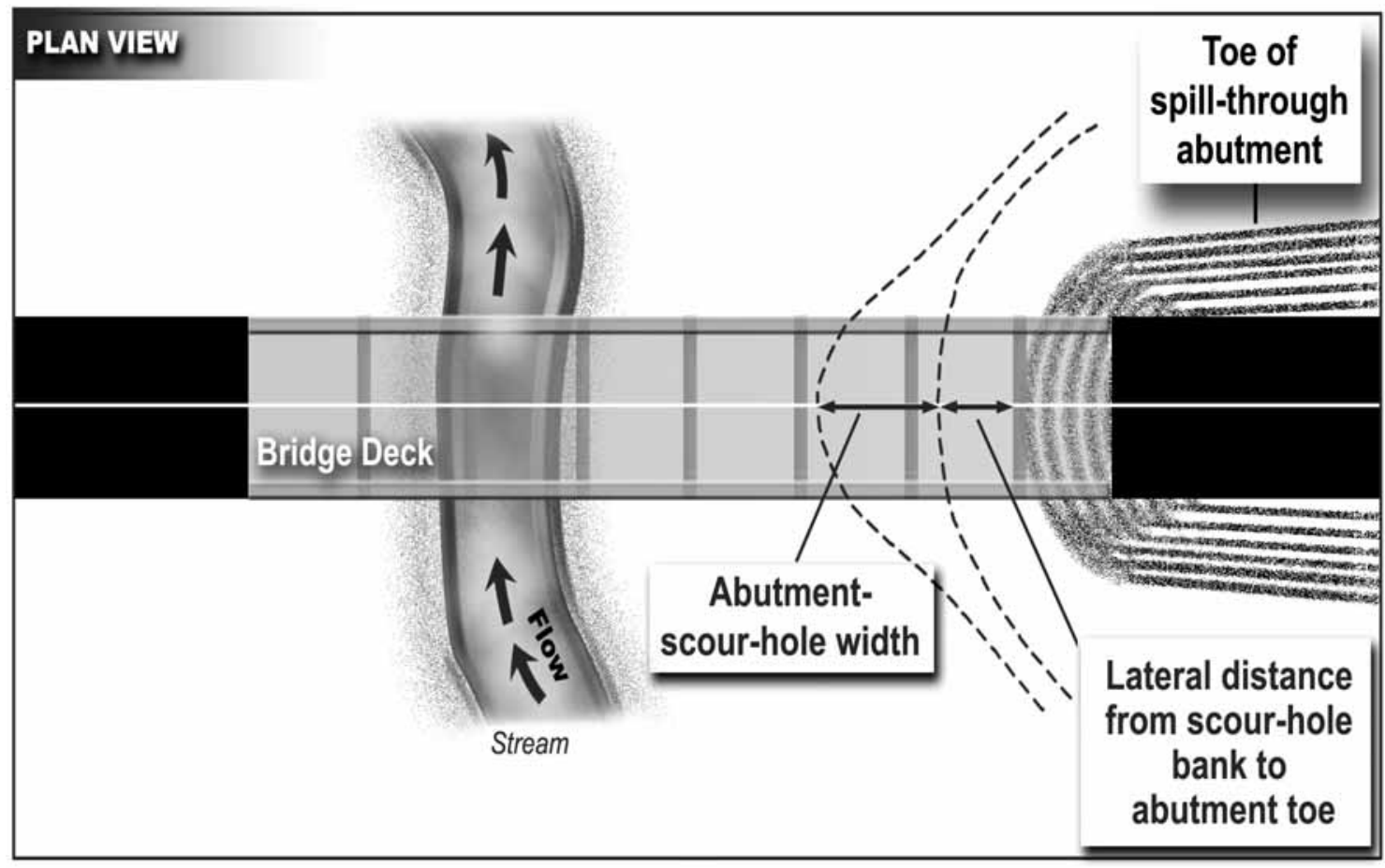

Figure 87. Plan view of reference for estimating the width and lateral location of an abutment-scour hole.

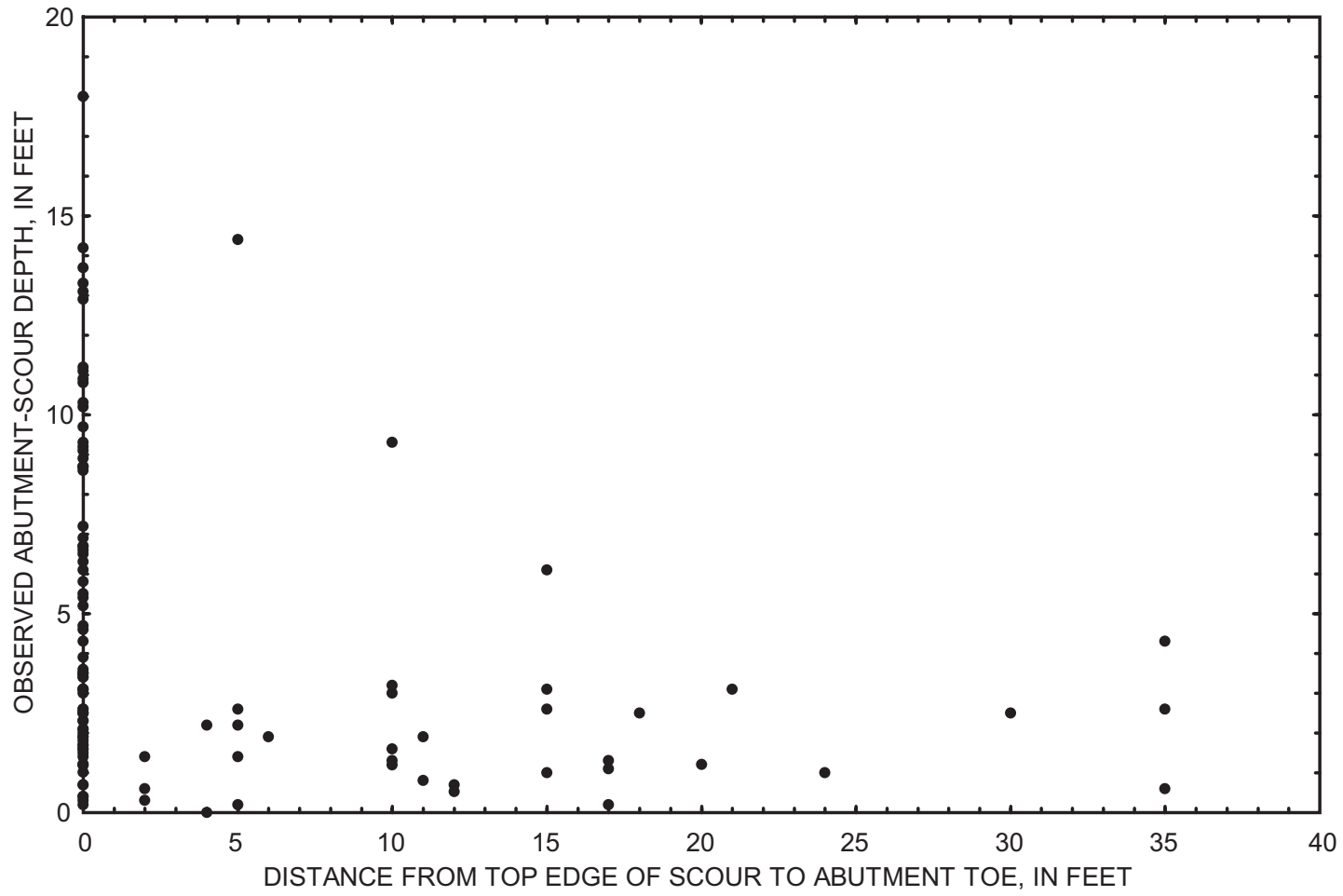

Figure 88. Lateral location of scour-hole bank in reference to the abutment toe for observed abutment scour in the Piedmont and Coastal Plain of South Carolina. 
A.

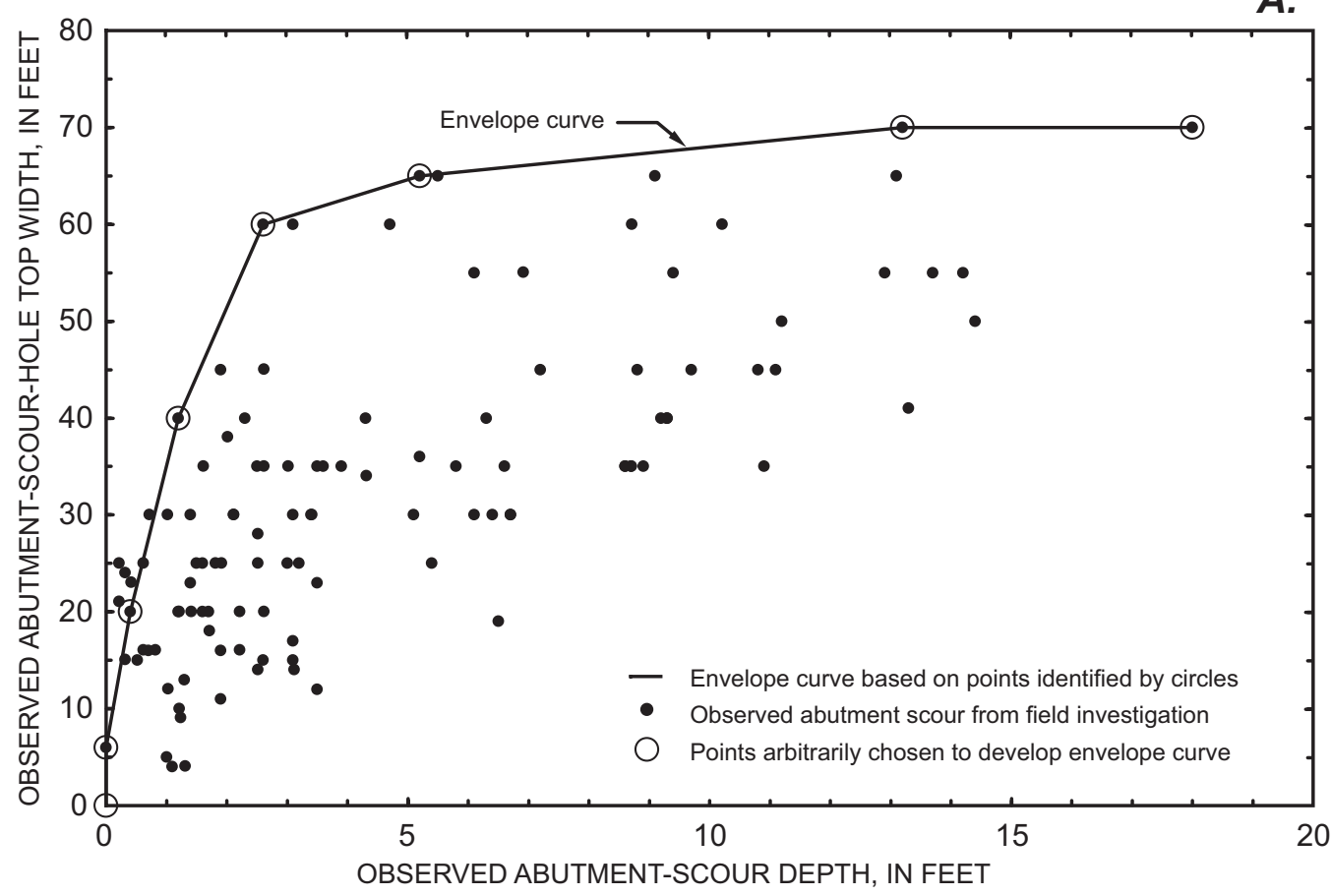

B.

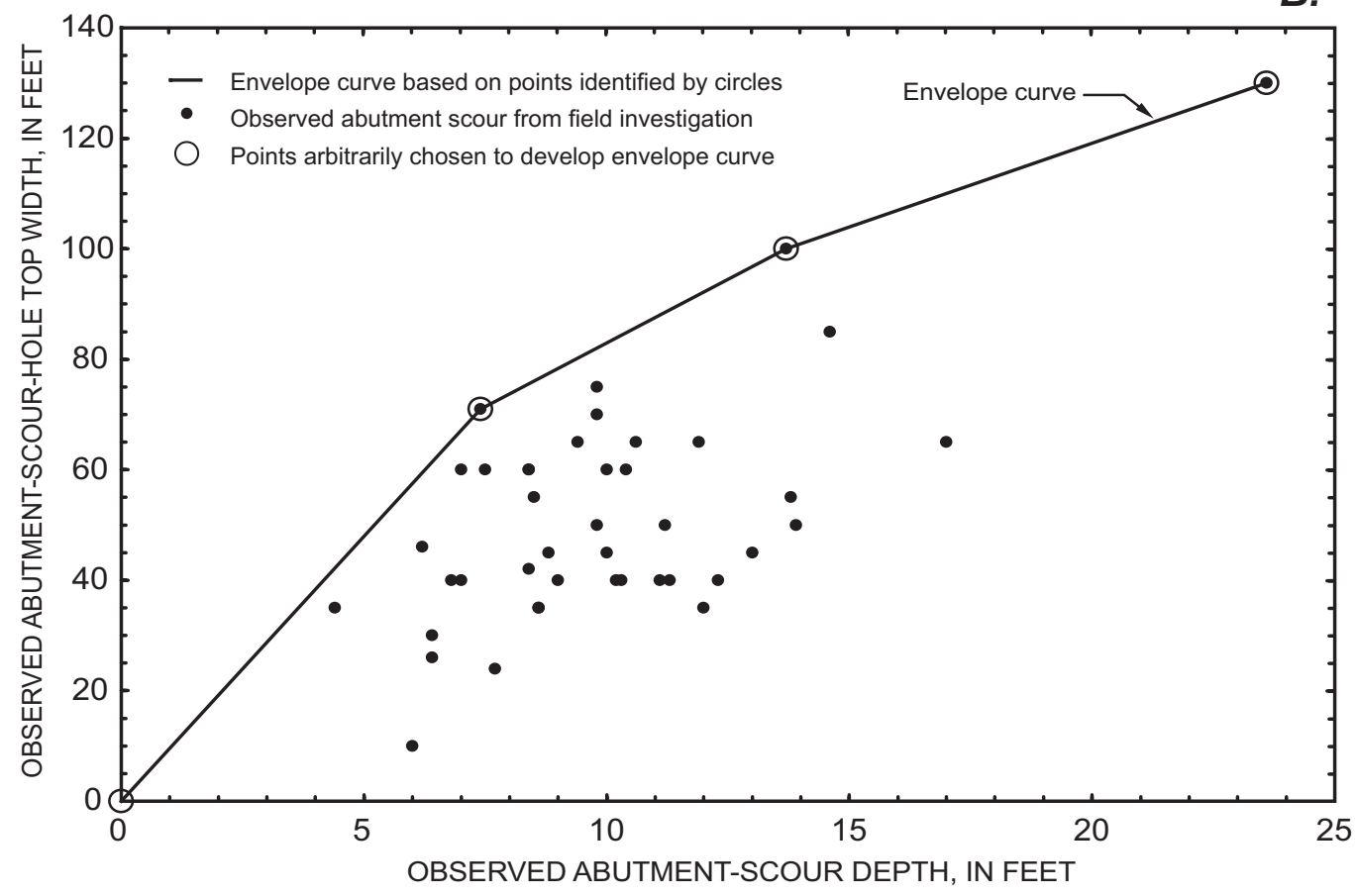

Figure 89. Relation of abutment-scour-hole top width and abutment-scour depth at bridges (A) greater than 240 feet in length, and (B) swampy and floodplain relief bridges, 240 feet or less in length in the Piedmont and Coastal Plain of South Carolina. 
A.

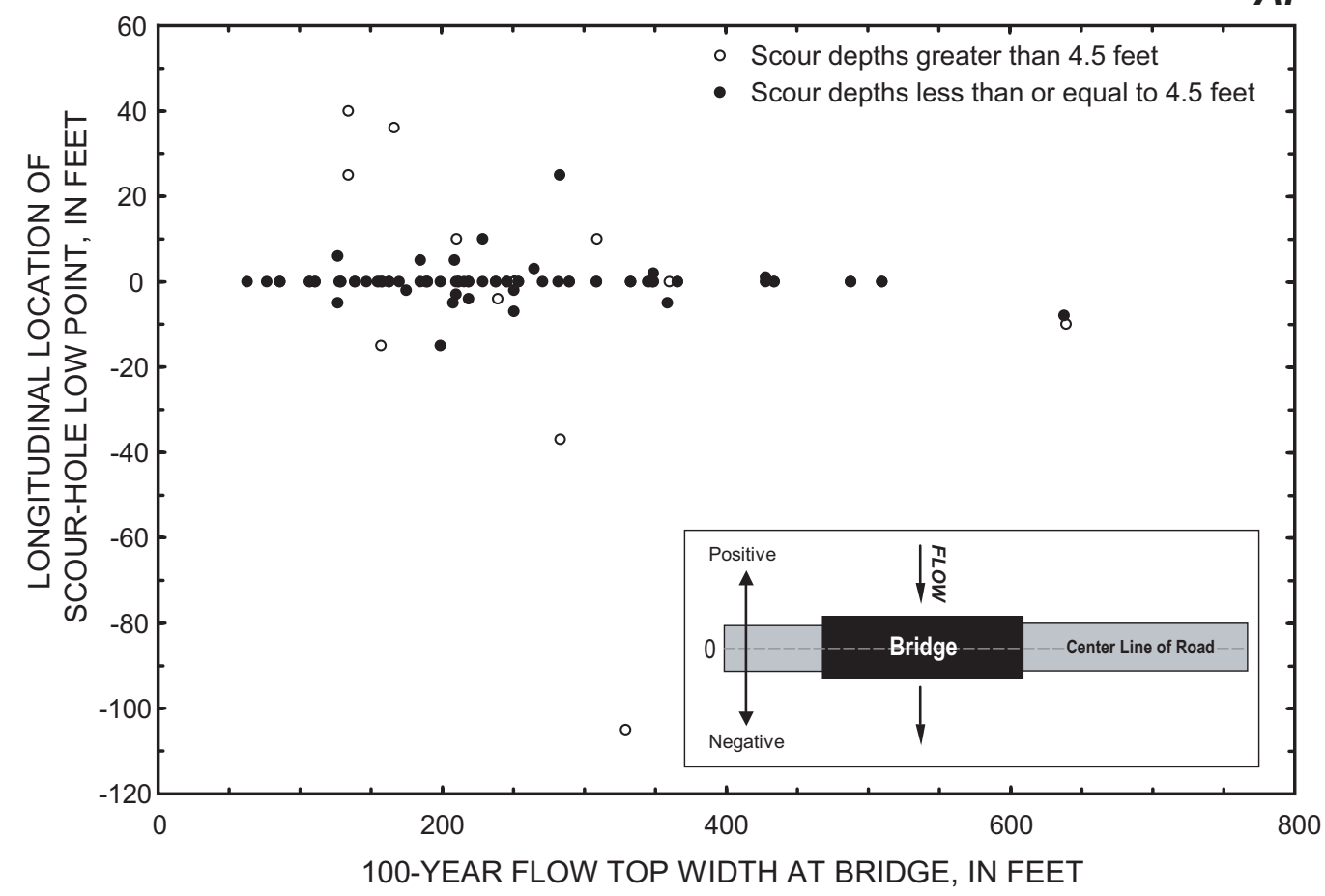

B.

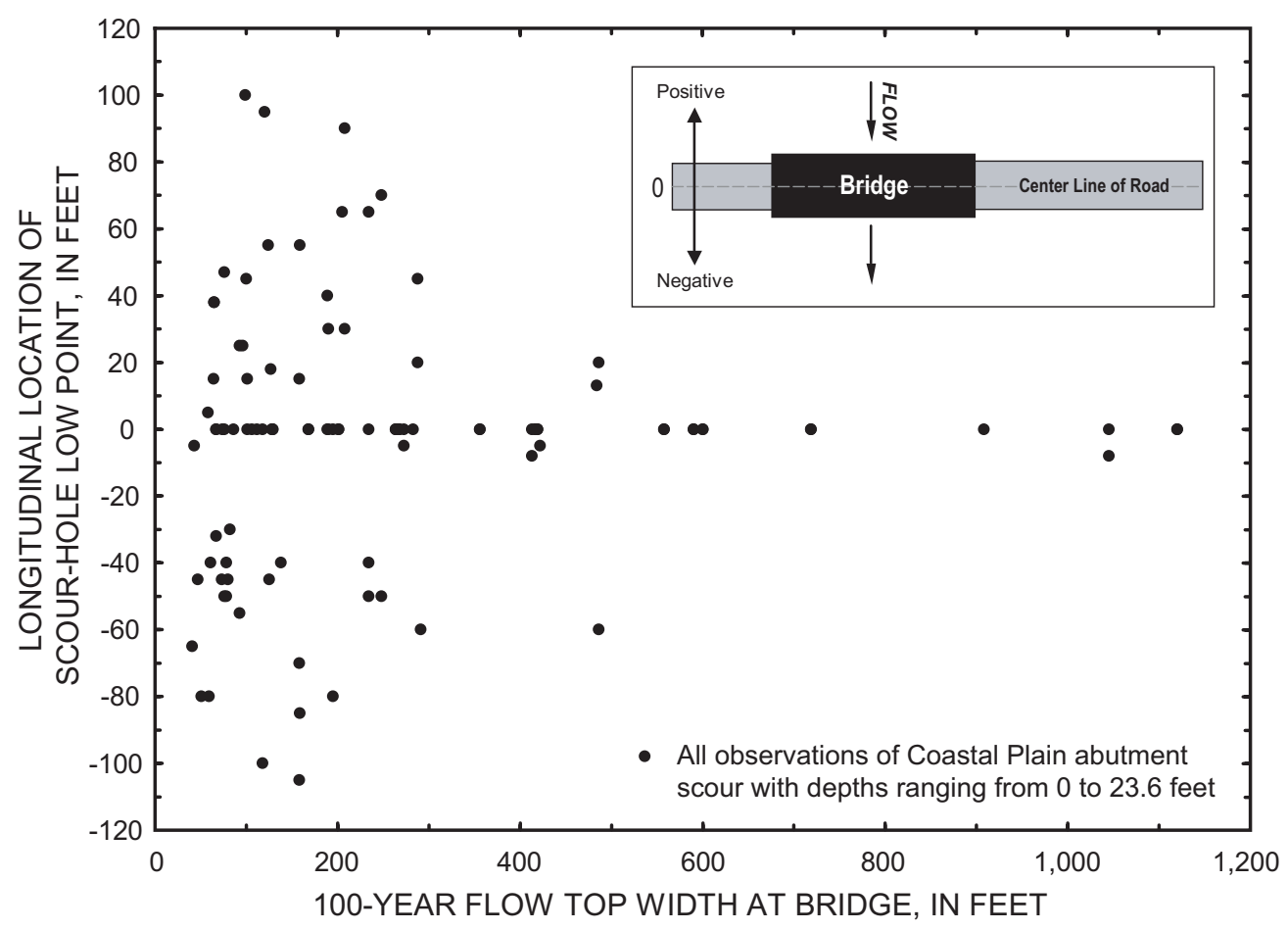

Figure 90. Relation of longitudinal location for the low point of the abutment-scour hole and the 100-year-flow top width at the bridge for (A) shallow and deep scour holes in the Piedmont of South Carolina, and (B) sites in the Coastal Plain of South Carolina. 


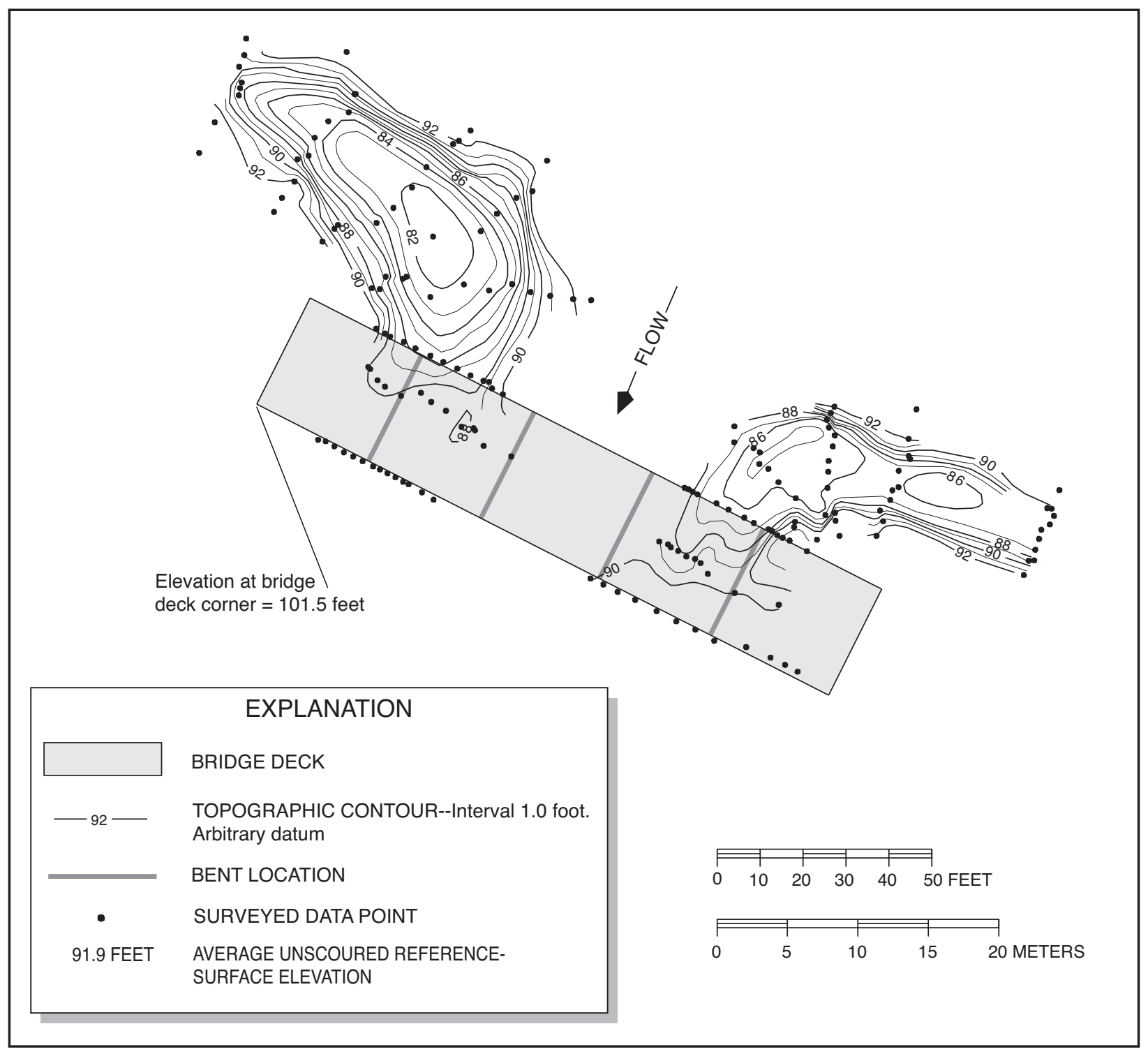

Figure 91. Example of scour-hole low point located upstream at Structure 367029900100 on Road S-299, crossing Cannons Creek in Newberry County, South Carolina, November 24, 1997.

flow patterns for shorter bridges, creating the scatter within the longitudinal pattern. As the bridge lengthens, the interaction of turbulent flow from left and right abutments is diminished and more stable flow patterns are established around each separate abutment. The stable flow patterns promote the creation of the classical abutment-scour hole pattern where the low point falls longitudinally near the bridge. Additional research is needed to confirm this speculation. Because the accurate prediction of longitudinal location of the scour hole is presently not possible, it must be assumed, for scour assessment purposes, that the scour-hole low point will be located directly at the bridge.

\section{Scour-Hole Shape}

Although cross-sectional shape at the low point of an abutment-scour hole varies, the general pattern is similar to a parabola. Data from the current study may be adequate to define a dimensionless shape for abutment-scour holes; however, this is outside the scope of this study. For assessing scour-hole shape at bridge foundations, it may be reasonable to use either a rectangle or trapezoid (fig. 93). The rectangle shape will certainly be conservative, but may overestimate scour at bridge foundations near the scour edges. Perhaps a more reasonable estimate of shape is the trapezoid, which somewhat mimics the side slopes of a parabola. 


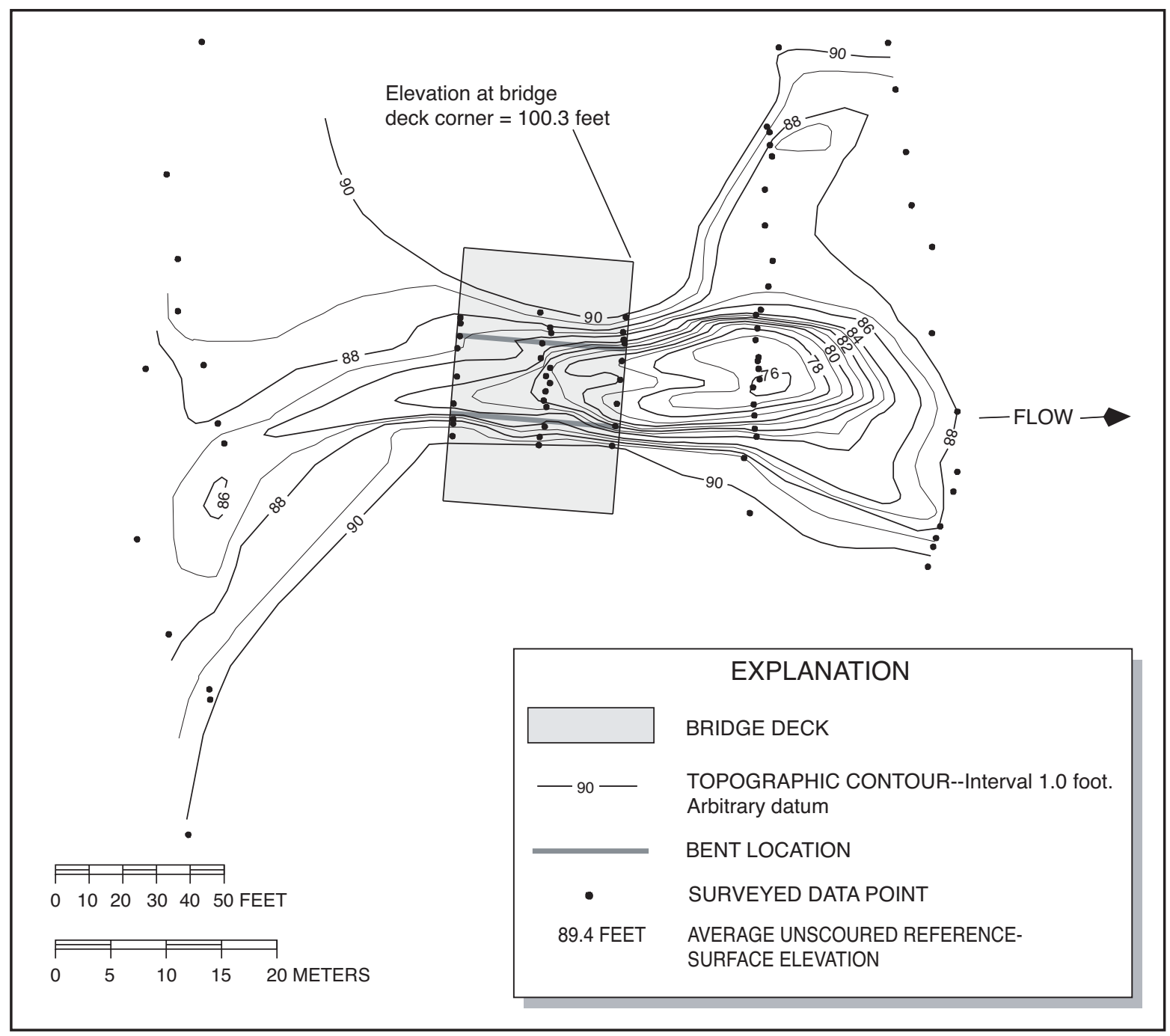

Figure 92. Example of scour-hole low point located downstream at Structure 344004100800 on S.C. Route 41, crossing Maiden Down Swamp in Marion County, South Carolina, December 3, 1996.

Use of a trapezoid requires judgment to select a side slope that will reflect anticipated slopes in the soil of interest. It should be kept in mind that steeper side slopes will widen the scour-hole bottom width providing a more conservative estimate of the impact of the scour hole.

\section{CLEAR-WATER CONTRACTION SCOUR IN THE PIEDMONT}

Densely vegetated floodplains of Piedmont streams, in combination with lower floodplain flow velocities, promote a region of clear-water scour on bridge overbanks (fig. 94). In this study, the width of the bridge overbank is defined as the distance from the abutment toe to the top of the channel bank. In the case of a floodplain relief bridge with no defined channel, the region of clear-water scour will be the width between the abutment toes (fig. 29). Under ideal conditions, flood flows contracted through a bridge opening will have flow patterns similar to those shown in figure 34. In the region near the abutment, contracted stream tubes produce increased velocities and the severe flow curvature produces vortices. Both conditions serve to promote abutment scour. Moving laterally away from the abutment, velocities and flow curvature diminish, reducing the potential for scour. If a bridge overbank is sufficiently wide, it will experience both the severely curved as well as the relatively straight flow patterns, and clear-water abutment scour and contraction scour may develop in these regions, respectively (fig. 95). 


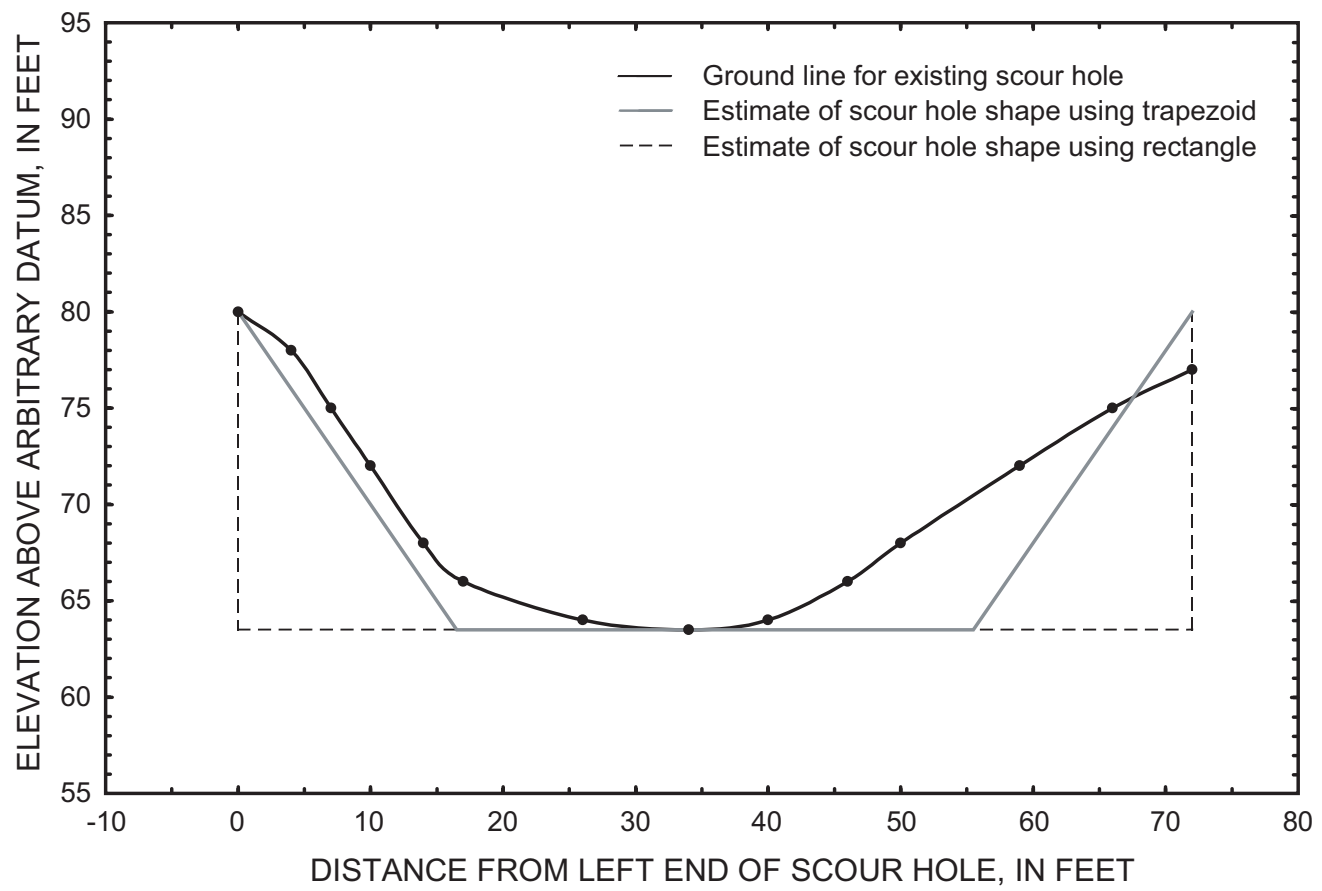

Figure 93. Ground line of existing scour hole compared with the shape of a trapezoid and rectangle.

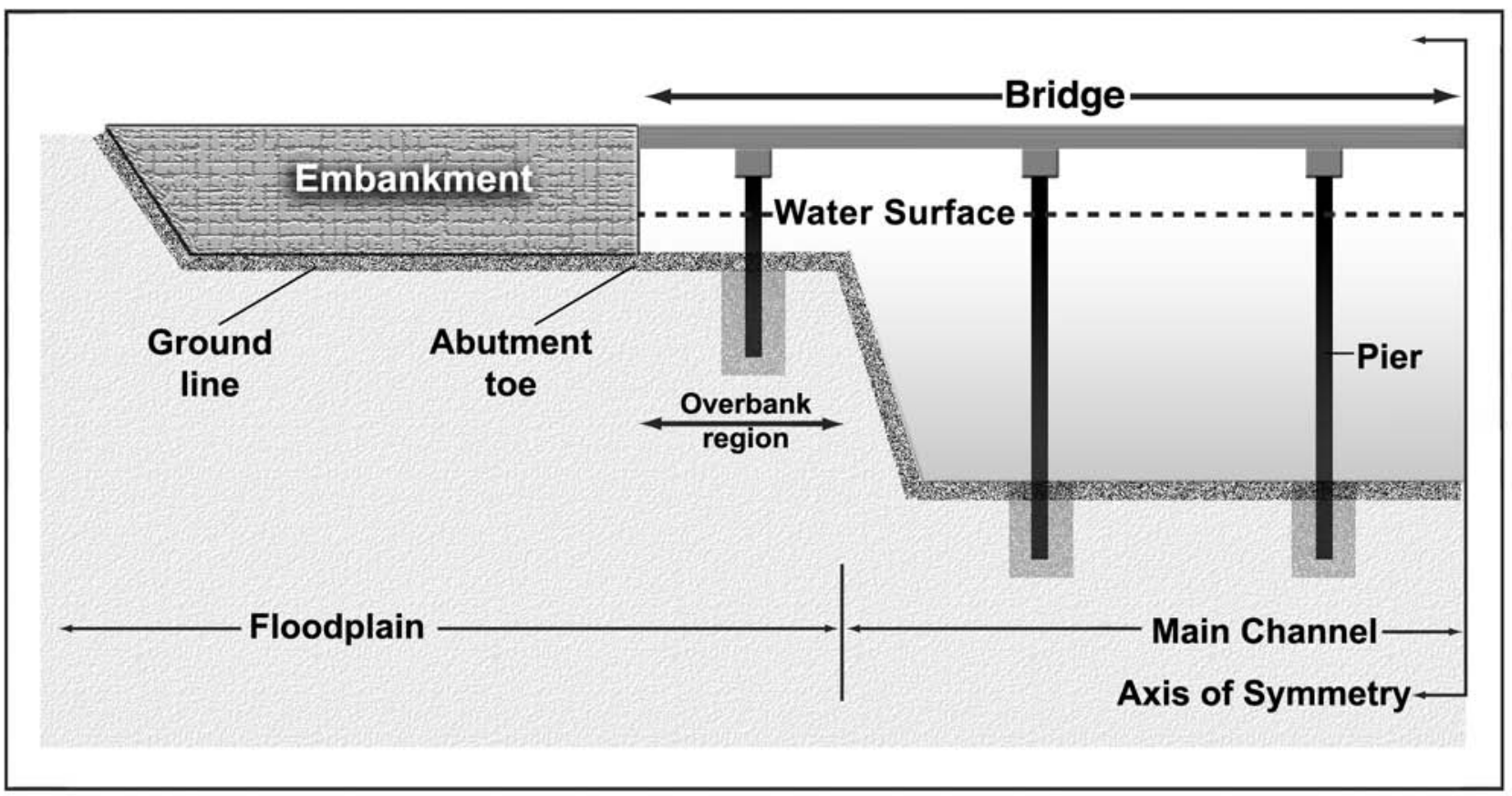

Figure 94. Profile of overbank area for bridges with setback abutments. 


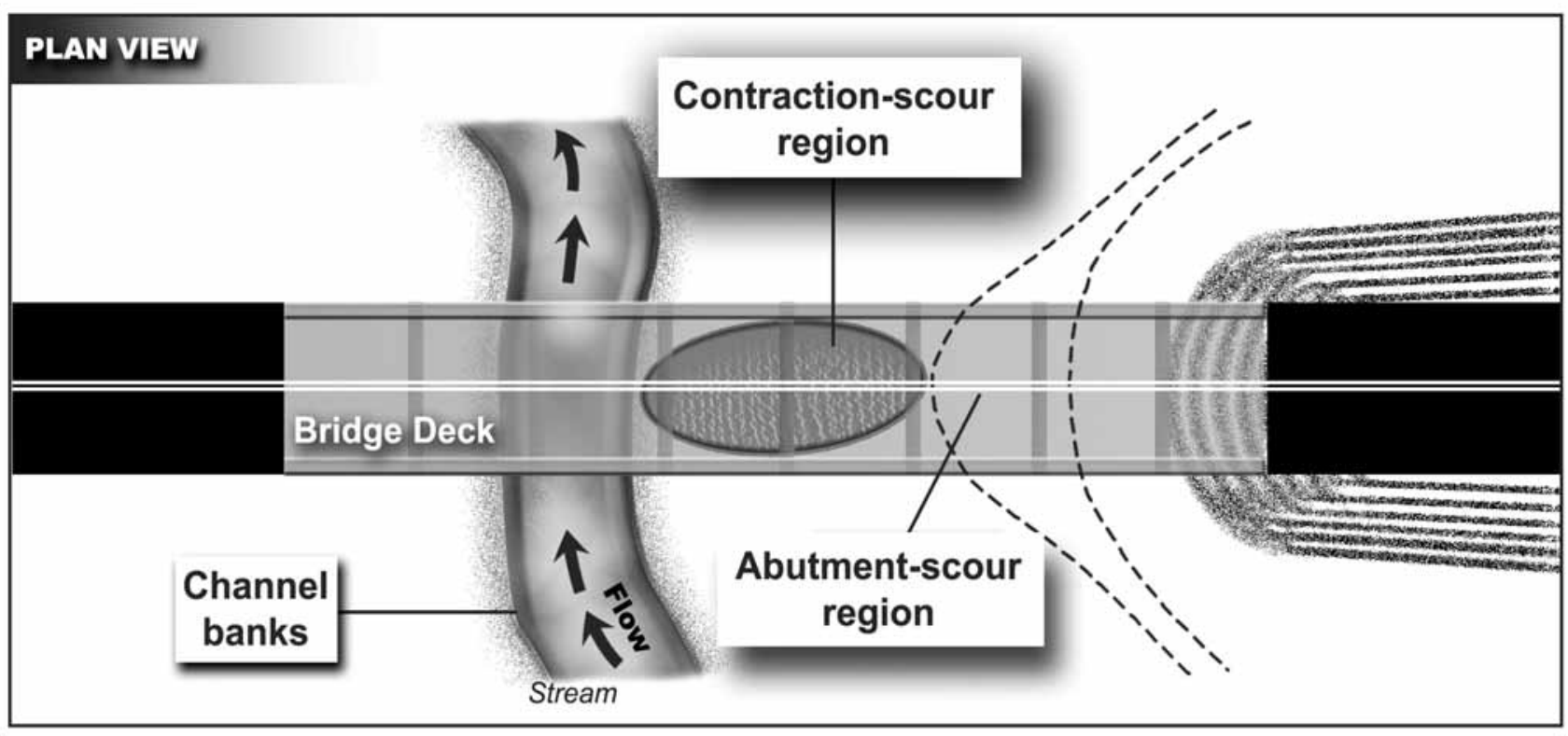

Figure 95. Plan view of areas of clear-water abutment and contraction scour.

In general, field observations of clear-water contraction scour in the Piedmont were collected in the clear-water contraction-scour region, as defined in figure 95 , outside of the region of abutment scour.

In this study, field data were collected during low-flow conditions and the boundary between severely curved and straight flow patterns at a given site was not defined. This boundary can often be estimated from scour-hole patterns observed in the field. Deeper abutment-scour holes typically occurred near the abutment toe with a substantially shallower scour occurring beyond this region. An example of this pattern can be seen at Structure 367008100200 on Road S-81 crossing the Enoree River in Newberry County (fig. 96). The large abutment-scour hole (fig. 97) is $13.7 \mathrm{ft}$ deep and is located in the abutmentscour region where severe flow curvature would be expected. Beyond the abutment-scour hole, the maximum clear-water contraction-scour depth is approximately $4 \mathrm{ft}$ (fig. 98), and is in the overbank region where straighter flow patterns would likely occur. Piedmont sites with smaller abutment-scour depths, often display a similar pattern of distinct abutment- and clear-water contraction-scour regions. The idealized flow patterns associated with a contraction provide some explanation of the differing scour potentials between the abutment- and clear-water contractionscour regions. Sediment-transport theory associated with rectilinear flow may provide insight for scour processes in this overbank region where straighter flow patterns dominate.

A total of 76 observations of clear-water contraction scour were collected at 53 bridge sites in the Piedmont Province, including 16 bridges in the high-flow region (fig. 1) (Guimaraes and Bohman, 1992). Scour depths ranged from 0 to $4.5 \mathrm{ft}$ with a median scour depth of $0.8 \mathrm{ft}$. Overbank widths ranged from 7 to $684 \mathrm{ft}$ with a median width of $61 \mathrm{ft}$. The dense vegetation and low velocities associated with Piedmont floodplains typically create clear-water scour conditions in the bridge overbank; all observed scour was considered clear-water in nature. The soils of the Piedmont tend to be scour-resistant clayey soils, but sandier soils also are present at some sites. Observations of clear-water contraction scour in the Piedmont included soils with varying degrees of cohesion. The clear-water contraction-scour holes on the bridge overbank region were typically limited to beneath the bridge and commonly formed a 


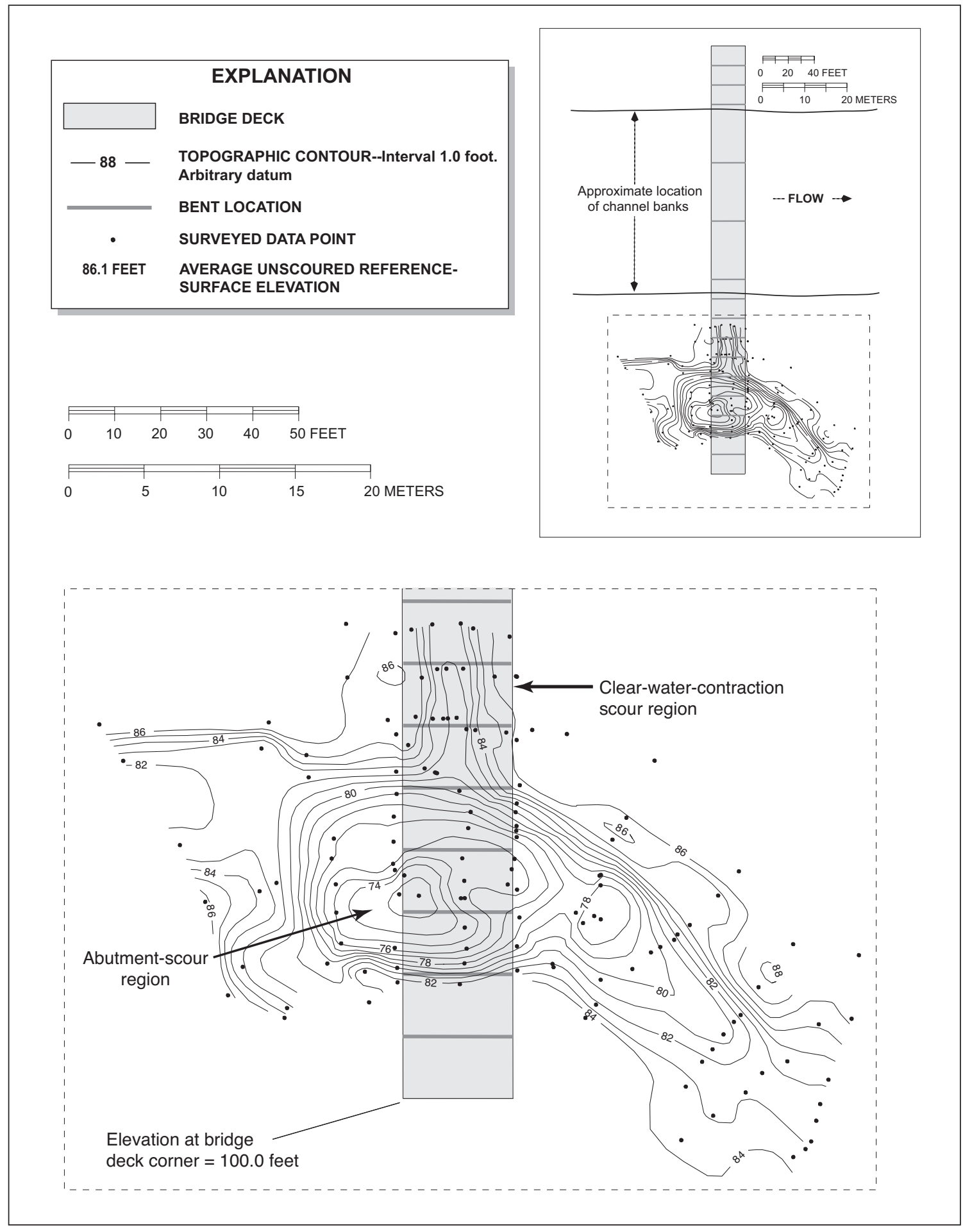

Figure 96. Example of abutment- and clear-water contraction-scour areas at Structure 367008100200 on Road S-81, crossing the Enoree River in Newberry County, South Carolina (April 7, 1997). 


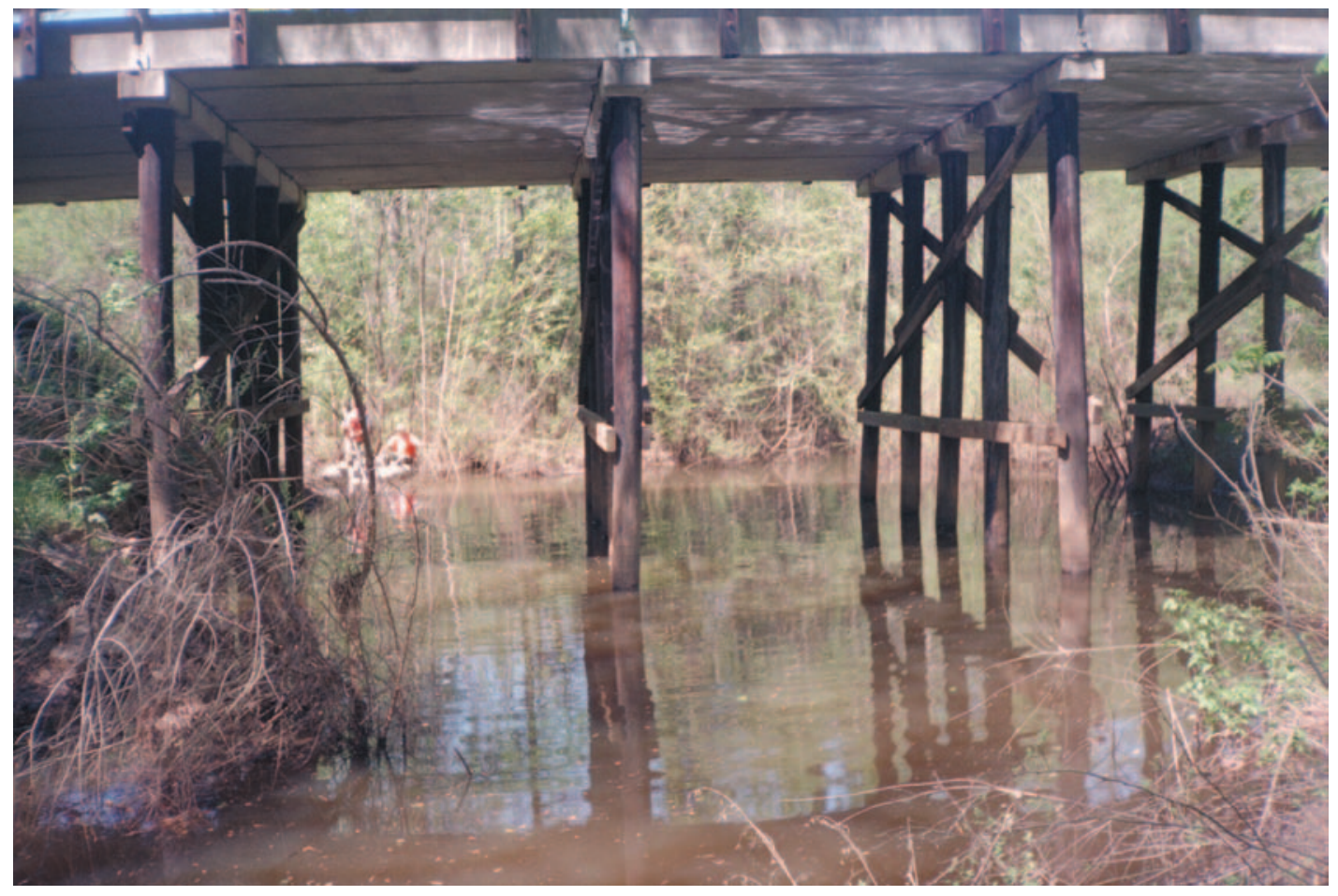

Figure 97. Right abutment-scour hole as viewed from downstream at Structure 367008100200 on Road S-81, crossing the Enoree River in Newberry County, South Carolina. The abutment-scour hole is inundated with ponded water. (Photograph by the South Carolina District, U.S. Geological Survey, April 7,1997.)

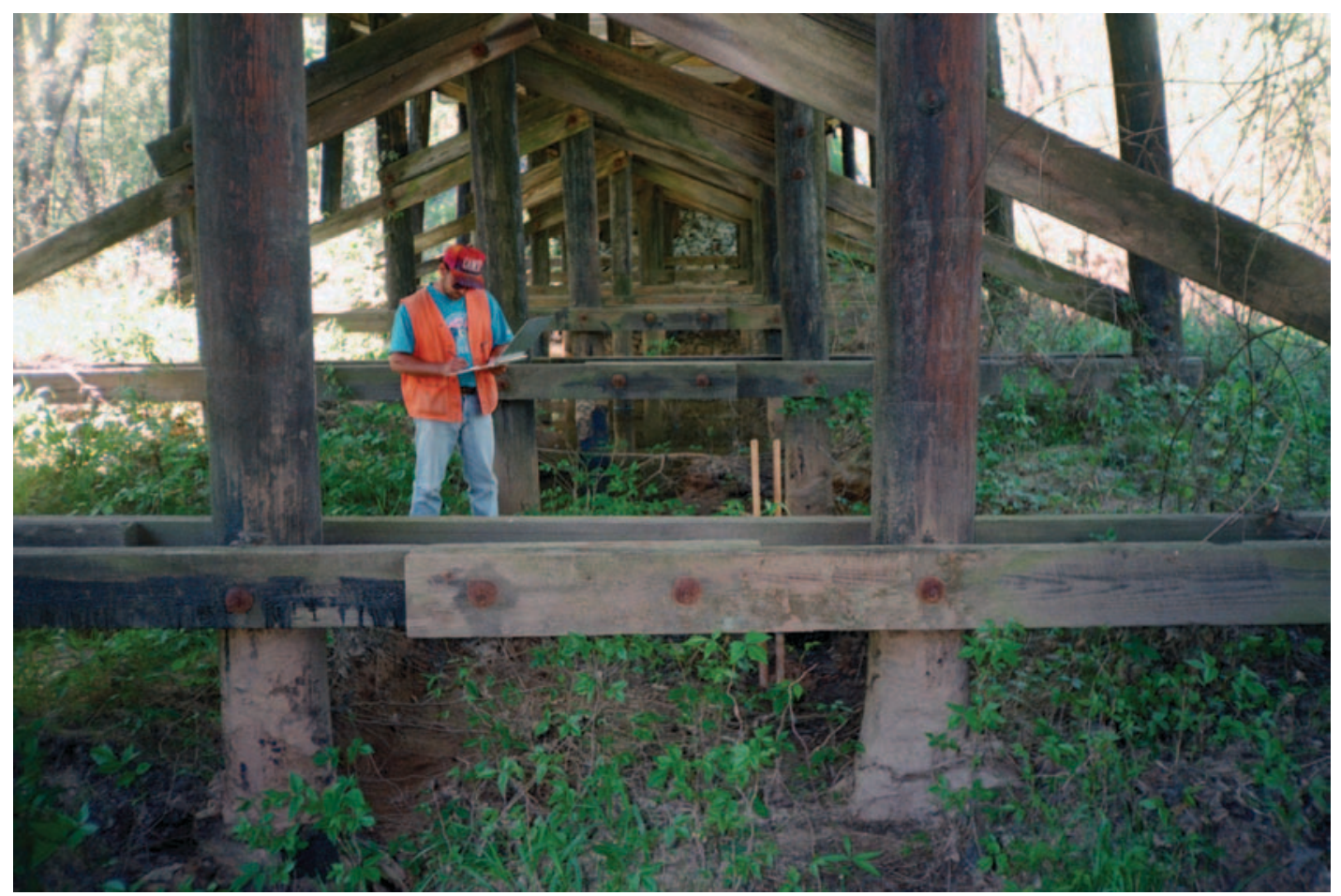

Figure 98. Clear-water contraction scour on the right overbank as viewed from the left at Structure 367008100200 on Road S-81, crossing the Enoree River in Newberry County, South Carolina. (Photograph by the South Carolina District, U.S. Geological Survey, April 7,1997.) 
shallow, parabolic depression running perpendicular to the flow (figs. 98, 99, and 100). Scour-hole patterns were commonly sufficient to distinguish clear-water contraction scour from abutment scour. When the scour-hole patterns were insufficient to distinguish these regions, clear-water contraction-scour data were collected away from the abutment toe. For small overbanks, the regions were often indistinguishable and judgment was required in classifying the scour as abutment or contraction. Table 14 lists the range of selected parameters associated with the 76 clear-water contraction-scour observations. Values for hydraulic data were estimated with the WSPRO model (Shearman, 1990) using the 100-year flow.

\section{Comparison of Observed and Theoretical Contraction-Scour Depths}

To estimate theoretical contraction-scour depth for clear-water scour conditions, HEC-18 (Richardson and Davis, 1995) recommends the use of Laursen's (1963) equation, which was derived for noncohesive sediments. Because Piedmont soils typically have some degree of cohesion, the equation often yields excessive scour depths for this region. Figure 101A compares the theoretical clear-water contraction-scour depth computed for the 100-year flow with the observed clear-water contraction-scour depth, and shows the excessive scour depths given by Laursen's equation for Piedmont soils. (To provide a meaningful scale in figure 101A, three theoretical scour depths of 30.3, 82.6 , and $88.0 \mathrm{ft}$ were excluded.) It should be kept in mind that the flows creating the observed contractionscour depths are unknown for most sites. The discrepancy between the observed and theoretical scour depths may, in part, be attributed to historic flows at these sites being less than the 100-year flow magnitude. However, maximum historic flows have been documented at 12 sites along the Reedy, South Tyger and Enoree Rivers (table 6). These flows occurred during the August 1995 flood and eight sites experienced flows exceeding the 100-year flow magnitude. A comparison of the theoretical contraction-scour depths, computed using the August 1995 flow magnitudes, with the observed scour still indicates excessive scour depths given by Laursen's equation (fig. 101B). The results of figure 101A are based on the hypothetical 100-year flow, whereas figure 101B represents observed and theoretical scour for known maximum historic flows. Therefore, the results of figure 101B likely provide a better indicator of how well the Laursen equation predicts theoretical scour in the Piedmont. Both figures, however, show that large discrepancies between observed and theoretical scour depths exist, suggesting that the Laursen equation is a poor predictor for clear-water contraction scour at Piedmont sites and that another method is needed to estimate clear-water contraction scour in this region.

\section{Geometric-Contraction Ratio as an Indicator of Potential Scour}

In general, as the geometric-contraction ratio increases, the flow velocity through a bridge opening will rise, increasing the potential for scour. Similar to abutment-scour in the Piedmont, it would seem reasonable to expect an increase in clear-water contractionscour depth with increasing geometric-contraction ratios. This general trend is apparent in the relation of clear-water contraction-scour depth and the 100-year flow geometric-contraction ratio for observed data in the Piedmont (fig. 102). Although the range of observed scour depth is small, the envelope for this data indicates that large clear-water contraction-scour depths are associated with large geometric-contraction ratios. An equation for this envelope is:

$$
y_{S}=-6.29 m^{2}+10.23 m+0.59 \text {, }
$$

where

$$
\begin{gathered}
y_{S} \text { is the upper limit of the range for anticipated } \\
\text { clear-water contraction-scour depth, in feet; and } \\
m \text { is the 100-year-flow geometric-contraction ratio; }
\end{gathered}
$$
where

$m=1-b / B$ with the variables previously defined.

Because observations of clear-water contraction scour are sparse beyond a geometric-contraction ratio of 0.85 , the envelope curve should be limited to sites with geometric-contraction ratios less than or equal to this value. Figure 103 shows the same information as presented in figure 102, but highlights the observed data from the 1995 flood. Several of the data points fall along or near the envelope, indicating that the curve provides some representation of the upper limit for clear-water contraction-scour depths that might occur at sites experiencing large flood flows. 


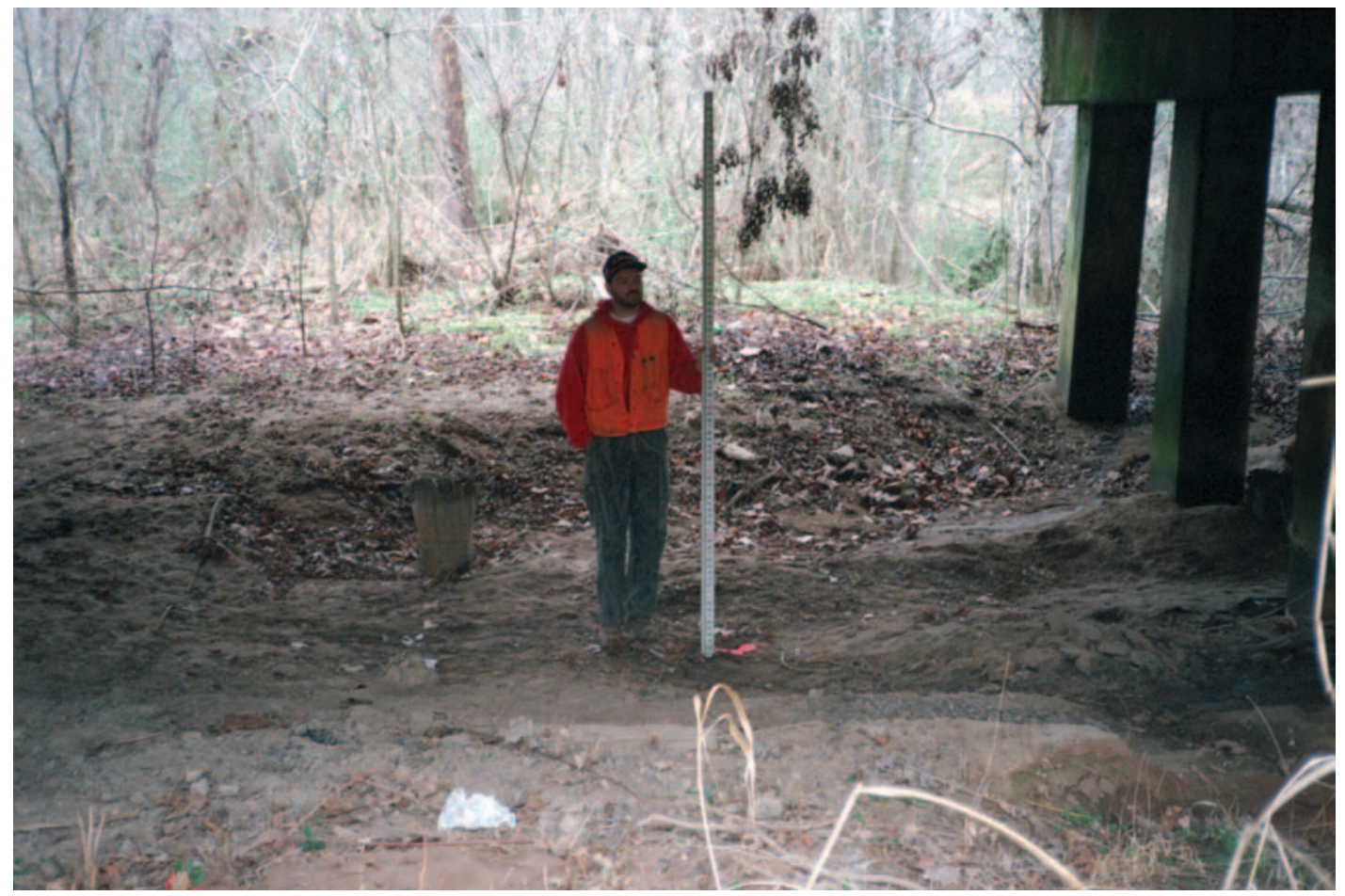

Figure 99. Example of shallow clear-water contraction scour at Structure 464032200300 on S.C. Route 322, crossing Fishing Creek in York County, South Carolina. (Photograph by the South Carolina District, U.S. Geological Survey, January 28,1997.)

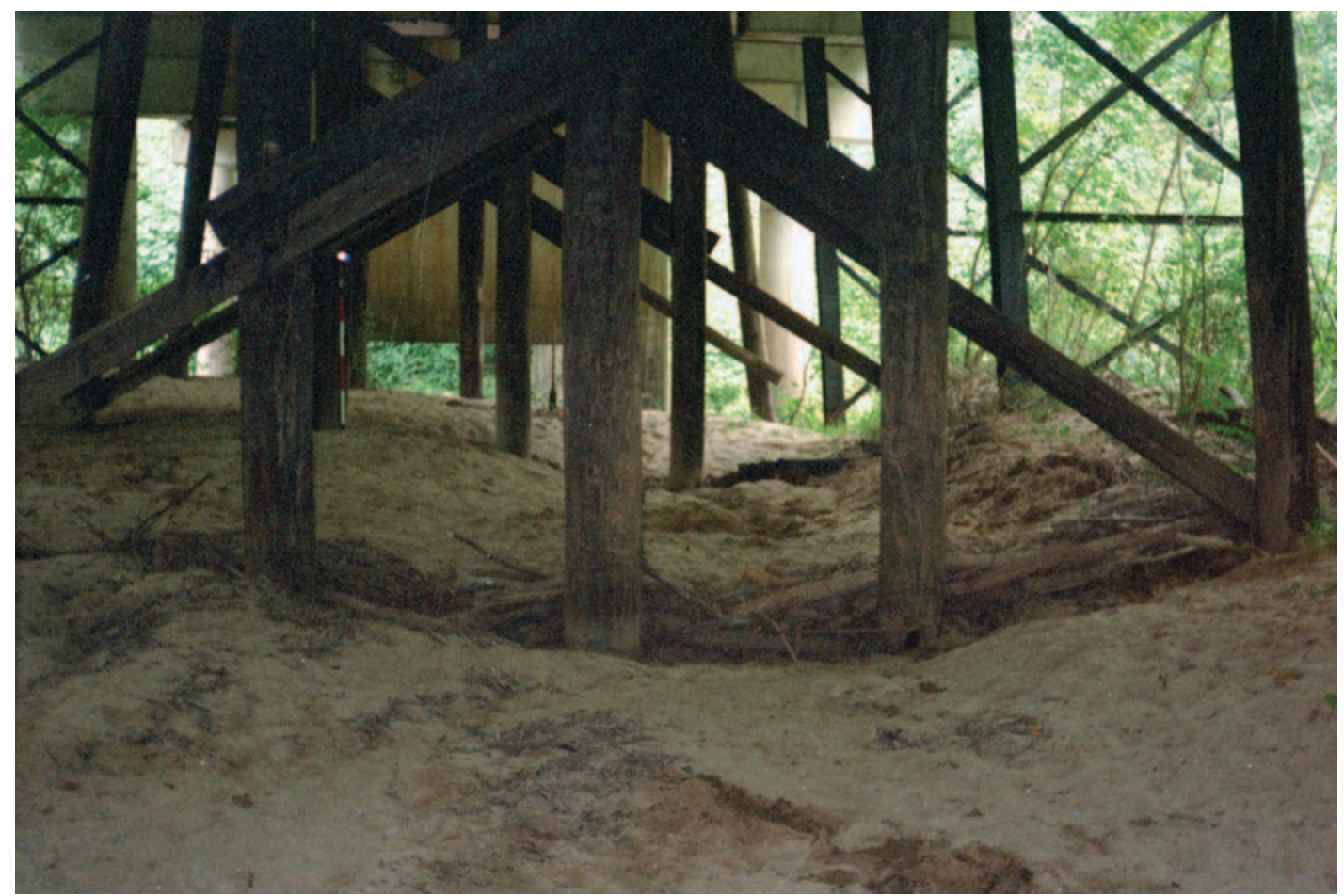

Figure 100. Example of shallow clear-water contraction scour at Structure 114000500200 on S.C. Route 5, crossing Buffalo Creek in Cherokee County, South Carolina. (Photograph by the South Carolina District, U.S. Geological Survey, October 7,1996.) 
Table 14. Range of selected parameters for 76 observations of clear-water contraction scour collected at 53 bridges in the Piedmont of South Carolina

$\left[\mathrm{mi}^{2}\right.$, square mile; ft/ft, feet per foot; $\mathrm{ft} / \mathrm{s}$, feet per second; $\mathrm{ft}$, feet; $\mathrm{mm}$, millimeter; <, less than]

\begin{tabular}{lccc}
\multicolumn{1}{c}{ Parameter } & $\begin{array}{c}\text { Minimum } \\
\text { value }\end{array}$ & $\begin{array}{c}\text { Median } \\
\text { value }\end{array}$ & $\begin{array}{c}\text { Maximum } \\
\text { value }\end{array}$ \\
$\begin{array}{l}\text { Drainage area }\left(\mathrm{mi}^{2} \text { ) }\right. \\
\begin{array}{l}\text { Channel slope determined from topographic } \\
\text { map (ft/ft) }\end{array}\end{array}$ & 11 & 76 & ${ }^{\mathrm{a}} 1,620$ \\
$\begin{array}{l}\text { 100-year flow average overbank velocity at } \\
\text { the bridge (ft/s) }\end{array}$ & 0.00015 & 0.0012 & 0.0029 \\
$\begin{array}{l}\text { 100-year flow average overbank depth at the } \\
\text { bridge (ft) }\end{array}$ & 1.6 & 3.2 & 6.2 \\
$\begin{array}{l}\text { Median grain size (mm) } \\
\text { Observed clear-water contraction-scour depth (ft) }\end{array}$ & 0.0 & 7.4 & 20.5 \\
\hline
\end{tabular}

${ }^{a}$ Approximately 97 percent of the study sites in the Piedmont have drainage areas less than $400 \mathrm{mi}^{2}$ (fig. 3).

${ }^{\mathrm{b}}$ Parameter was estimated from the one-dimensional water-surface profile model, WSPRO (Shearman, 1990).

The envelope curve in figure 102 encompasses all of the field data, as well as all sites influenced by the 1995 flood, so it is reasonable to assume that the envelope represents an upper range of potential scour for a given geometric-contraction ratio. With this assumption, the envelope can be used as a tool for assessing potential clear-water contraction-scour depths in the overbanks of Piedmont streams. Because the envelope represents an upper limit of observed scour depth, it will likely overpredict scour depth for various site conditions; however, the envelope will not exceed the upper bound of observed field data. In contrast, theoretical scour computed with the Laursen (1963) equation frequently exceeds the upper bound of observed data (fig. 104), indicating the geometric-contraction-ratio envelope is a better method for assessing potential clear-water contraction-scour depths in the Piedmont. (To provide a meaningful scale in figure 104, three theoretical scour depths of $30.3,82.6$, and $88.0 \mathrm{ft}$ were excluded.)

The envelope curve shown on figure 102 and equation 15 can be used for sites in the Piedmont to estimate a range of anticipated clear-water contraction-scour depths for geometric-contraction ratios of 0.85 or less. From a practical view, it may be appropriate to use an envelope value of $4.5 \mathrm{ft}$ for all geometric-contraction ratios less than or equal to 0.85 . Only sites having similar characteristics to sites used in this study should be assessed using this envelope. Because the envelope was developed from a limited sample of bridges in the Piedmont, scour depths could exceed the envelope. Therefore, it may be prudent to apply some type of safety factor to the envelope. When using this envelope, it is critical to properly estimate the geometric-contraction ratio at a given site. To ensure that the ratio is properly assessed, various sources of data should be reviewed, including, but not limited to, topographic maps, hydraulic models, road plans, and field observations. The envelope was developed using field data encompassing sites experiencing flows approaching the 100-year flow and, therefore, should not be used to assess clear-water contraction-scour depths for extreme events such as the 500-year flow.

\section{Selecting a Reference Surface for Clear-Water Contraction Scour}

In this study, the average, undisturbed floodplain elevation in the clear-water contraction-scour region was used to determine contraction-scour depth. This reference surface should be used when assessing clear-water contraction scour with the contraction-scour-depth envelope. This reference surface can be determined by reviewing floodplain elevations from SCDOT road and bridge plans, surveyed cross ections, and (or) site visit observations. In many cases, the floodplain in the region of clear-water contraction scour is relatively flat, and estimating an average floodplain elevation is not a difficult task. However, there can be cases where the floodplain slopes substantially in the lateral and (or) longitudinal direction making the determination of a reference surface more difficult. In such cases, judgment should be applied, bearing in mind that lower reference-surface elevations will produce lower scour-hole elevations. 
A.
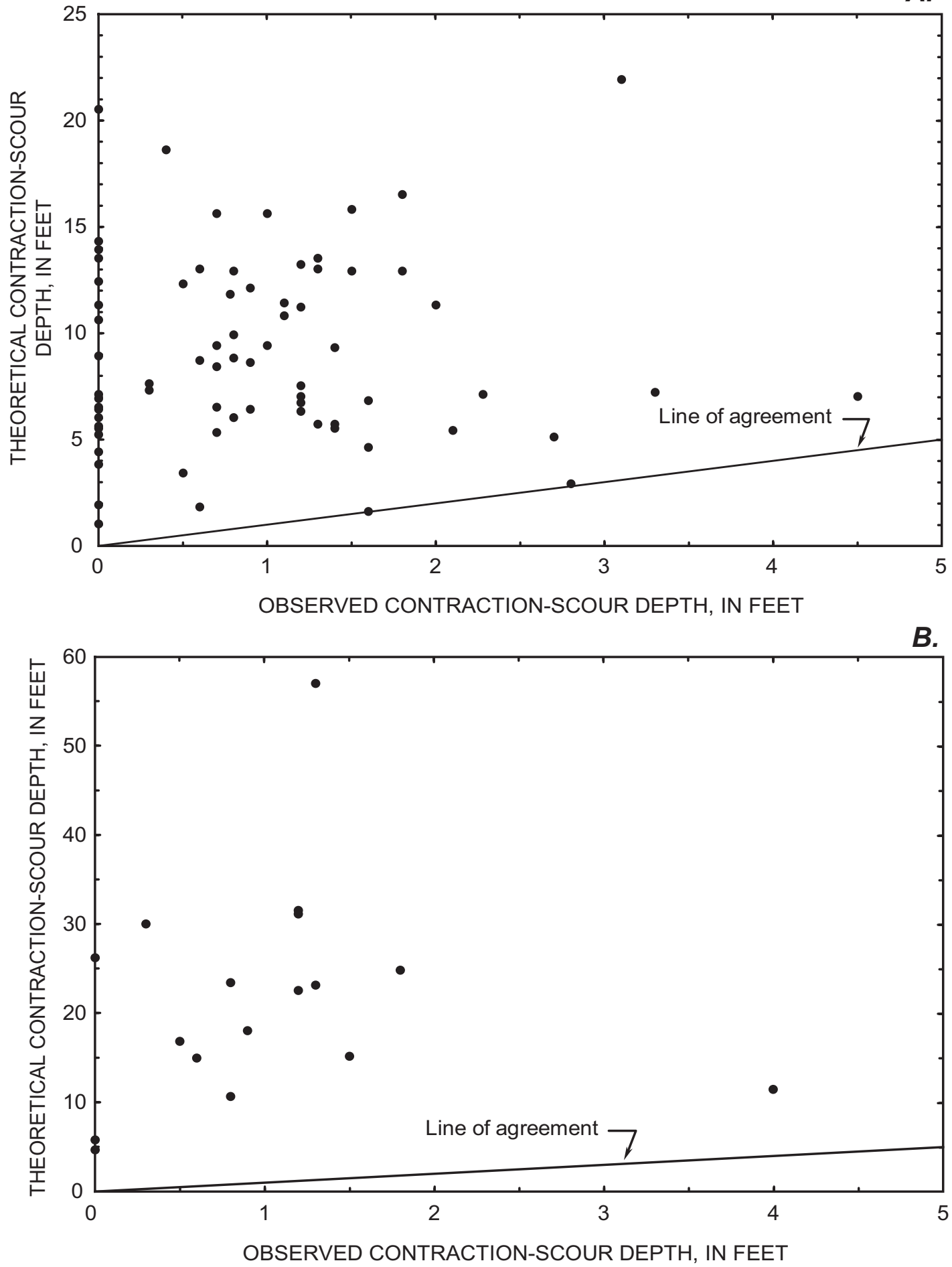

Figure 101. Relation of observed and theoretical clear-water contraction-scour depth for the (A) 100-year flow, and the (B) August 1995 flood at selected sites in the Piedmont of South Carolina. (Theoretical contraction scour calculated with the Laursen (1963) equation.) 


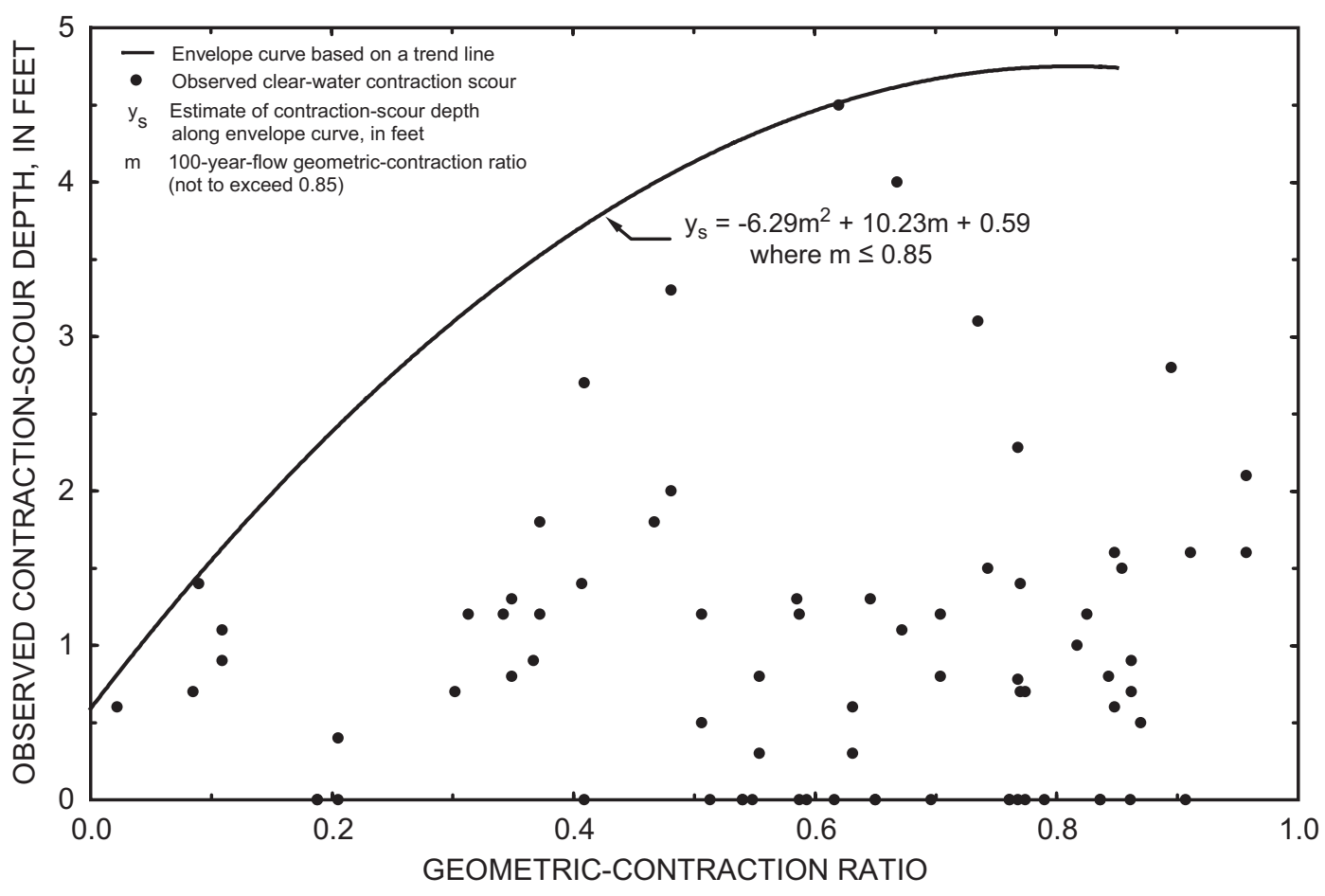

Figure 102. Relation of observed clear-water contraction-scour depth and the 100-year-flow geometric-contraction ratio in the Piedmont of South Carolina.

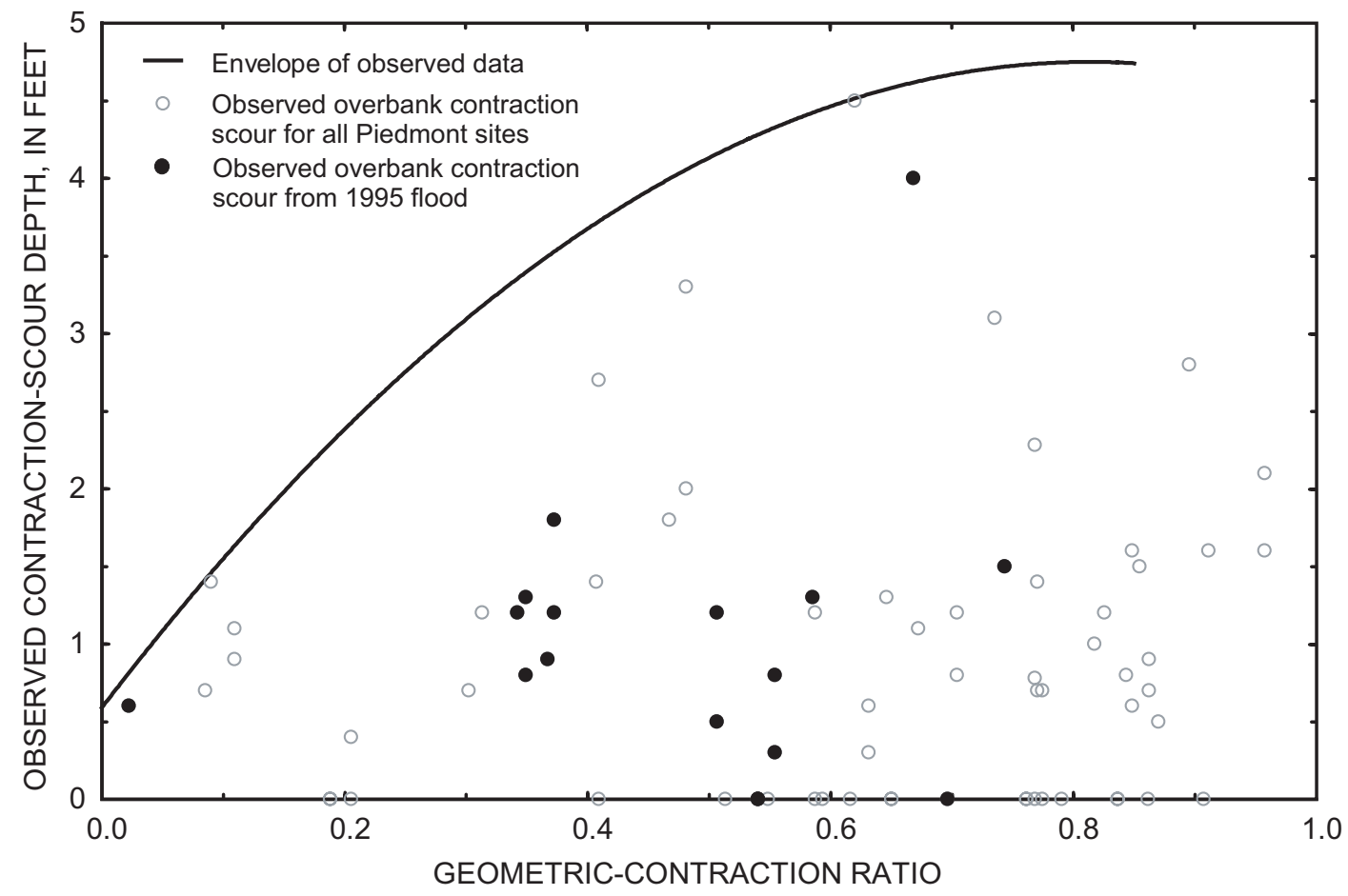

Figure 103. Relation of observed clear-water contraction-scour depth and the 100-year-flow geometric-contraction ratio identifying sites for the 1995 flood in the Piedmont of South Carolina. 


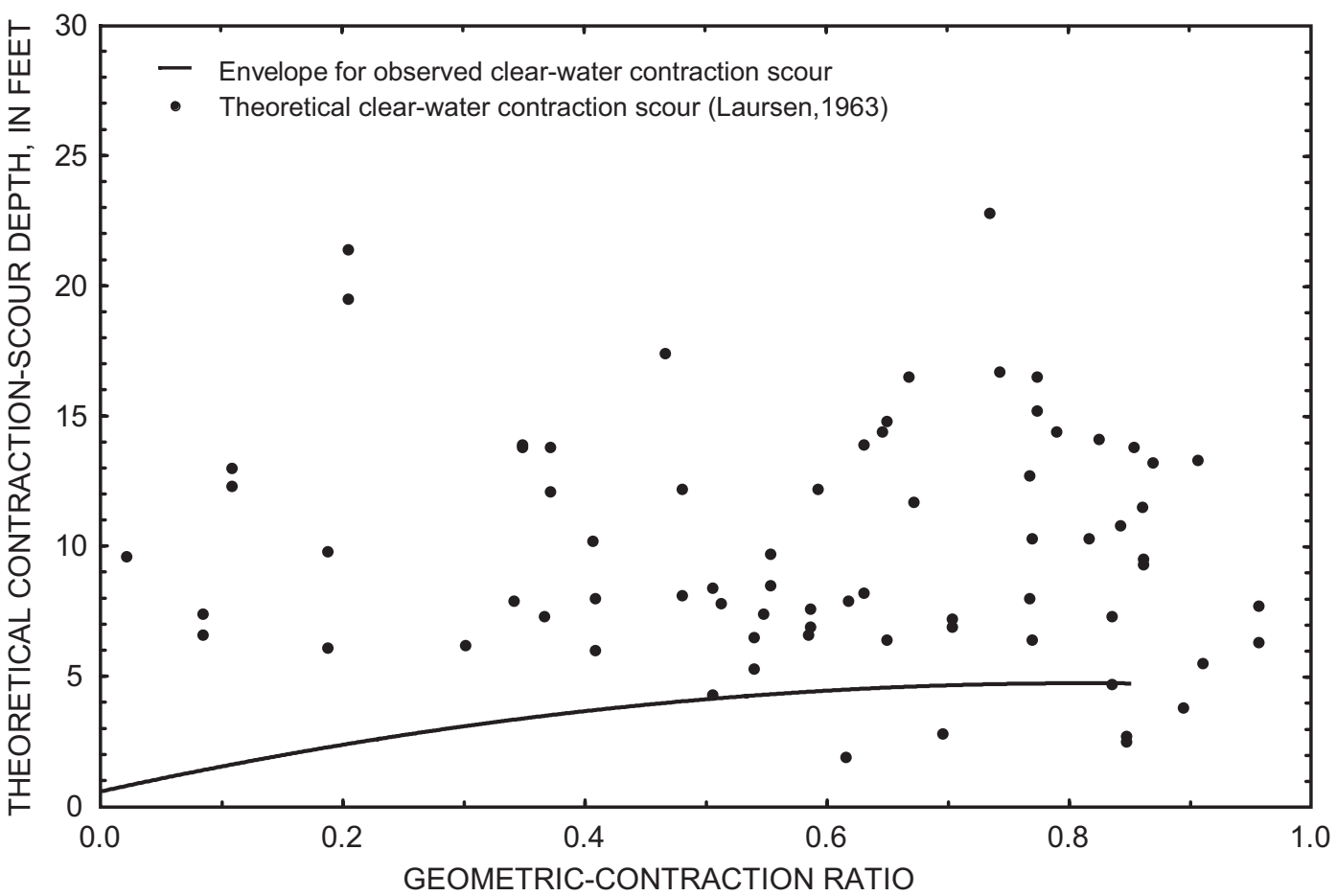

Figure 104. Relation of theoretical 100-year-flow clear-water contraction-scour depth and the 100-year-flow geometric-contraction ratio compared with the envelope of observed data in the Piedmont of South Carolina. (Theoretical clear-water contraction scour calculated with the Laursen (1963) equation.)

\section{Pier Scour within Clear-Water Contraction-Scour Areas}

Because of the shallow nature of clear-water contraction-scour holes, it was generally possible to distinguish the region of pier scour from the region of clear-water contraction-scour. When collecting data at these sites, scour around piers generally was not included in the measurement of clear-water contraction scour. Therefore, the envelope in figure 102 represents contraction scour only and not the total scour. This envelope can be used to assess anticipated ranges of clear-water contraction scour in Piedmont overbanks, but judgment should be used to account for any additional scour created by piers or bents.

A potential threat to overbank piers that is not addressed in this study is channel widening. Channel widening can undermine overbank piers that are located near a channel bank. In 1995, the Enoree River in the Piedmont of South Carolina experienced a large flood that significantly exceeded the 100-year flow magnitude at various locations along the river (table 5). Post-flood field visits to bridges along the Enoree River, indicated that various reaches of the main channel had experienced channel widening from bank erosion. At some locations widening was sufficient to remove material from around piles set near the channel bank (fig. 105). Table 15 compares pre- and post-flood channel top widths at three sites along the Enoree River and demonstrates the effect that large floods can have on channel widening and the potential threat to piers near channel banks. One should be aware of this potential problem and use judgment when assessing scour at overbank piers or bents near channel banks.

\section{Estimate of Clear-Water Contraction-Scour Hole Location}

In general, the shape of clear-water contractionscour holes in the overbank region, observed in the Piedmont, consisted of shallow parabolic depressions running perpendicular to flow (fig. 100) and covering most of the overbank region unaffected by abutment scour (fig. 95). Figure 106 shows the relation of clearwater contraction-scour depth and the longitudinal location of the low point of the scour hole in reference to the centerline of the roadway. In general, the low 


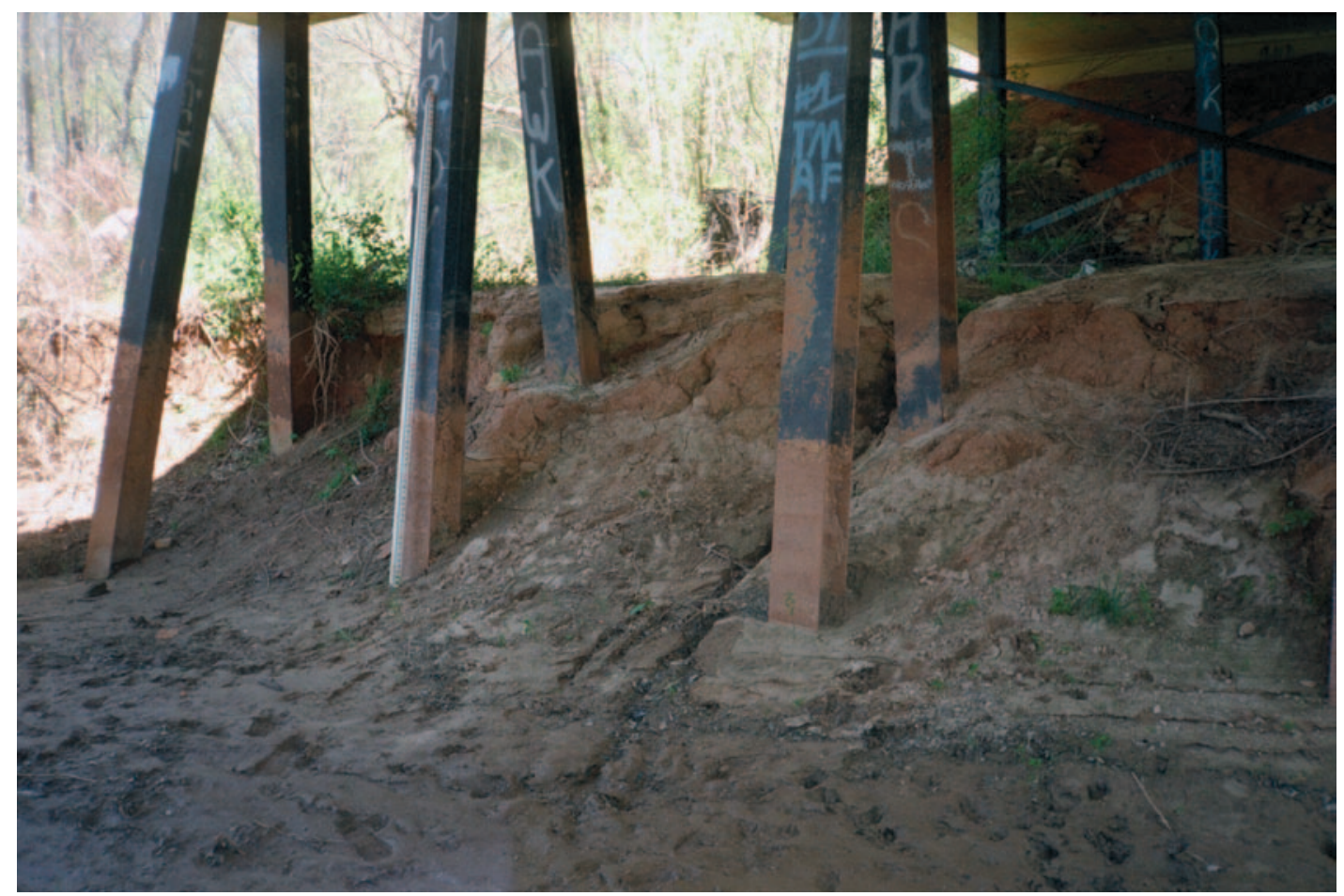

Figure 105. Erosion of bed material from around piles caused by bank widening from the August 1995 flood at Structure 307026300100 on Road S-263, crossing the Enoree River in Laurens County, South Carolina. (Photograph by the South Carolina District, U.S. Geological Survey, April 1, 1997.)

point is in close proximity to the roadway centerline and all observations are located beneath the bridge deck. The left and right lateral extent of the clear-water contraction scour typically began at the edge of the abutment-scour hole and ran toward the bank (fig. 95). Scour depths over the lateral extent of the scour hole varied. To account for this, observed scour was measured at the deepest area over the lateral extent.

Data are insufficient to predict the exact location of clear-water contraction-scour holes. The data suggest, however, that it is reasonable to assume the scour will occur under the bridge and will extend laterally from the edge of the abutment-scour hole to the channel bank. The range of anticipated contractionscour depths can be assessed using the clear-water contraction-scour envelope (fig. 102). The upper limit of this range can be applied across the entire overbank region from the edge of the abutment-scour hole to the channel bank. Because the edge of the abutment-scour hole will be a limiting boundary for the clear-water contraction scour, abutment scour at the bridge should be assessed first.

Table 15. Pre- and post-flood channel top widths for the 1995 flood at selected sites along the Enoree River in the Piedmont of South Carolina $\left[\mathrm{mi}^{2}\right.$, square miles; $\mathrm{ft}^{3} / \mathrm{s}$, cubic feet per second; $\mathrm{ft}$, feet; S-, Secondary Road]

\begin{tabular}{|c|c|c|c|c|c|c|}
\hline County & Road & $\begin{array}{c}\text { Drainage } \\
\text { Area } \\
\left(\mathrm{mi}^{2}\right)\end{array}$ & $\begin{array}{l}\text { Peak flow } \\
\text { for } \\
1995 \text { Flood } \\
\left(\mathrm{ft}^{3} / \mathrm{s}\right)\end{array}$ & $\begin{array}{l}\text { Pre-flood } \\
\text { channel } \\
\text { top width a } \\
\text { (ft) }\end{array}$ & $\begin{array}{l}\text { Post-flood } \\
\text { channel } \\
\text { top width } \\
\text { (ft) }\end{array}$ & $\begin{array}{c}\text { Reference } \\
\text { number } \\
\text { (fig. } 1 \\
\text { and } \\
\text { app. B) }\end{array}$ \\
\hline Spartanburg & S-118 & 186 & 64,200 & 95 & 121 & 130 \\
\hline Laurens & S-263 & 249 & 50,400 & 113 & 140 & 94 \\
\hline Laurens & S-112 & 256 & 50,000 & 113 & 148 & 93 \\
\hline
\end{tabular}

${ }^{\mathrm{a}}$ Widths determined from the South Carolina Department of Transportation bridge plan surveys. 


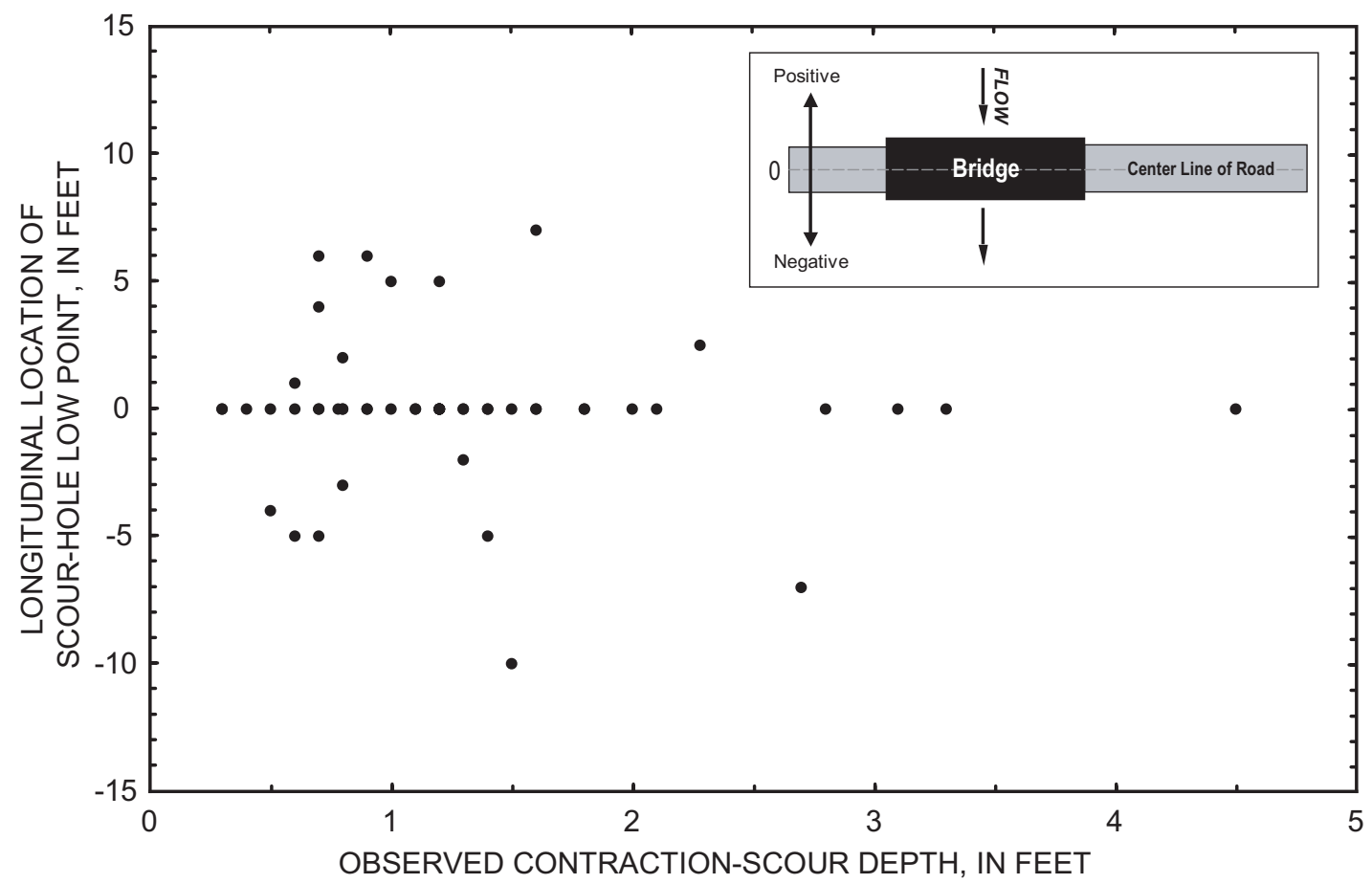

Figure 106. Relation of longitudinal location for the low point of the clear-water contraction-scour hole and observed contraction-scour depth in the Piedmont of South Carolina.

\section{Permissible Velocities for Clear-Water Contraction Scour}

The concept of permissible velocities can provide some insights as to why clear-water contraction scour in the Piedmont is relatively small. Using field data from irrigation canals and the experience of field engineers, Fortier and Scobey (1926) defined ranges of permissible velocities that a given soil could sustain without significant erosion. Fortier and Scobey (1926) state that the permissible velocity should not be confused with the critical velocity that defines the point of incipient motion for a loose particle of given grain size. In general, permissible velocities for given field conditions will be higher than critical velocities. According to the study, cohesive clayey soils have permissible velocities in the range of 3.75 to $5.0 \mathrm{ft} / \mathrm{s}$. In addition, firm loamy materials can sustain flows in the range of 2.5 to $3.5 \mathrm{ft} / \mathrm{s}$. Richardson and others (1990) cite information from a U.S. Army Corps of Engineers publication (Keown and others, 1977) that gives suggested ranges for permissible velocities for cohesive and noncohesive soils somewhat similar to Fortier and Scobey (1926). (This publication describes the velocities as nonscour velocities instead of permissible velocities.) The cohesive soils are defined as sandy loams, which are a mixture of sands, silts, clays, and organics of varying degrees. In general, this description encompasses soils typically found in the Piedmont. The permissible velocities suggested by Keown and others (1977) for this type of soil ranges from 3.1 to $4.9 \mathrm{ft} / \mathrm{s}$, with the permissible velocity increasing as flow depth increases.

Permissible velocities, as described by Fortier and Scobey (1926) and Keown and others (1977) are for rectilinear flows. As discussed previously, flow patterns in the overbank region are approximately rectilinear and the use of permissible velocities to assess the potential for clear-water contraction scour at bridge overbanks may be reasonable. Figure 107 shows the relation of the observed clear-water contraction-scour depth and the average overbank velocity for the 100year flow. (The actual historic velocities at these sites 


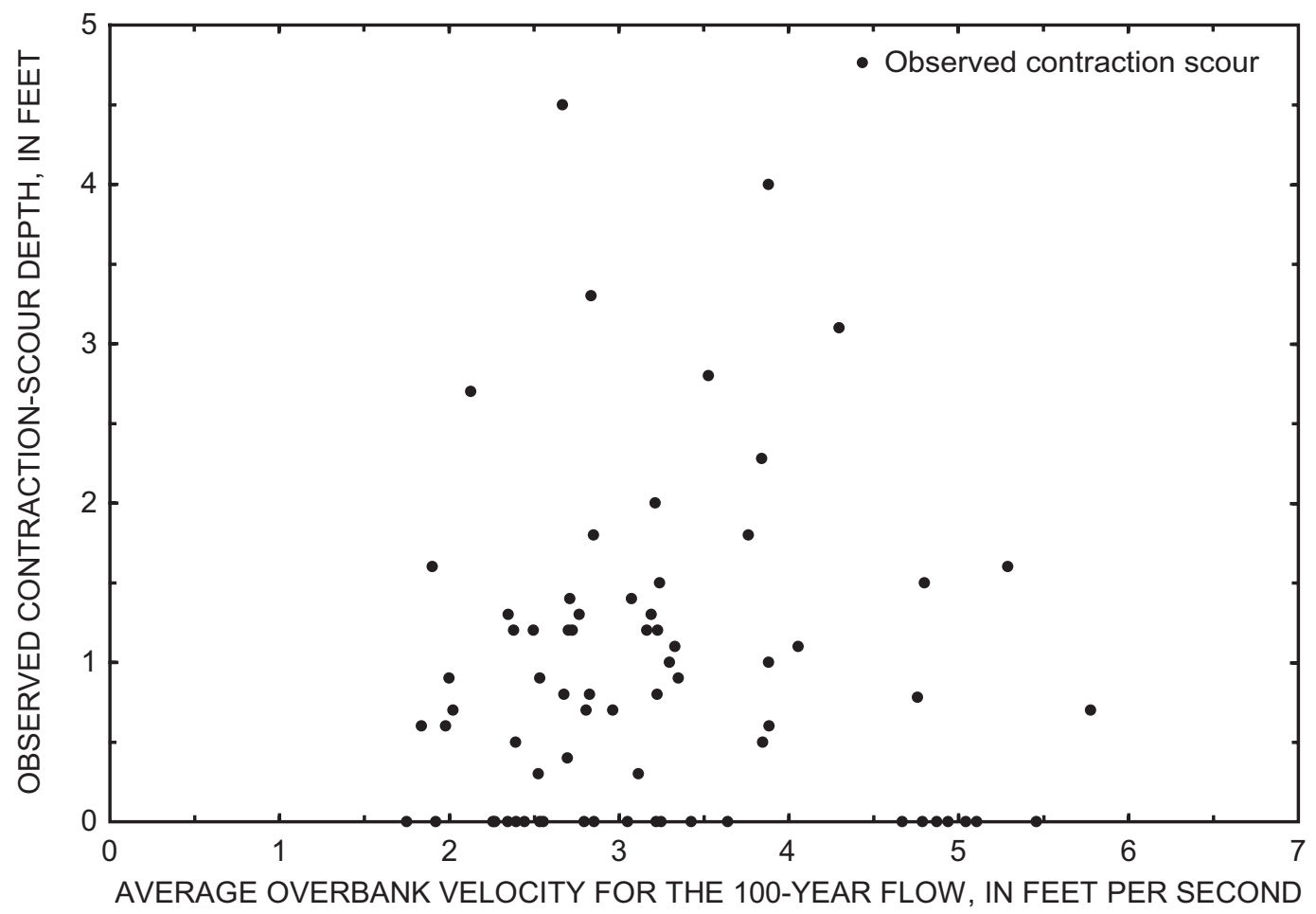

Figure 107. Relation of observed clear-water contraction-scour depth and the average overbank velocity for the 100-year flow in the Piedmont of South Carolina.

are unknown, but the 100-year flow velocity provides insight on the range of velocities that could occur during large floods.) This relation indicates that most sites have velocities that are less than $3.5 \mathrm{ft} / \mathrm{s}$, which is near the lower limit of permissible velocity for clayey soils and near the upper limit for firm loams, according to Fortier and Scobey (1926). According to Keown and others (1977), $3.5 \mathrm{ft} / \mathrm{s}$ is near the lower end of permissible velocities for cohesive sandy loams. Of the 25 observations that have velocities exceeding $3.5 \mathrm{ft} / \mathrm{s}, 20$ are associated with clayey soils that in general are more scour-resistant and could possibly sustain higher velocities without significant scour. Figure 107 illustrates that many sites investigated in this study have average overbank velocities that are within the range of permissible velocities. Therefore, the potential for scour is low and significant amounts of scour should not be anticipated. This provides some explanation for the relatively small amounts of contraction scour observed on Piedmont overbanks. This also indicates that permissible velocity may be a useful tool to qualitatively assess the potential for contraction scour in the overbank region. The works of Fortier and Scobey
(1926), Keown and others (1977), and Richardson and others (1990) should be consulted to further understand the application and limitations of permissible velocities.

If many of the overbanks in the current study have high-flow velocities that are within the range of permissible velocities, one could question why scour is observed at many of these sites. A definitive answer is not available, but some speculation follows. Although the overbank region has flow patterns that are relatively straight in comparison to the severe curvature near the abutment, the flow patterns still have some curvature. This may introduce additional bed stresses and vortices that may increase the potential for scour giving some explanation as to why small amounts of scour are observed. Scour in the overbank region could also, in part, be attributed to lateral flows under the bridge. At several sites, there was evidence that flows had run along the overbank region toward the main channel rather than perpendicular to the bridge opening. One source for such flow is stormwater runoff from the roadway and bridge deck, as well as seepage of stormwater through bridge deck joints. An additional source 
is from shallow floodplain flows that occur during smaller flood events. Under these conditions, shallow flows might seek a path of least resistance along the bare soils found in the overbank regions of many bridges. It is suspected that observed scour in the overbank region is a combination of various factors including contraction scour, which will occur at higher flow conditions, as well as lateral flow from stormwater runoff and shallow flood flows.

\section{THE SOUTH CAROLINA BRIDGE-SCOUR DATABASE}

Selected data generated from this study has been compiled into a database called the South Carolina Bridge Scour Database (SCBSD), and can be viewed using Microsoft Access. The SCBSD includes photographs, figures, selected field data, variables used to compute theoretical scour, computed scour depths, limited basin characteristics, limited soil data, and selected hydraulic data estimated with the WSPRO model (Shearman, 1990). These raw data are compiled in various data tables within the database, and automated reports have been developed to allow extraction of selected data for a chosen bridge. The SCDOT assigns a unique 12-digit number for each bridge under its jurisdiction and these numbers are used in the database as the primary search variable for extracting selected data from the raw data tables for display in the automated reports. Appendix A contains a description of the SCBSD automated reports, raw data tables, and variable definitions.

The SCBSD was developed using Microsoft Access 2000. The electronic file for the database requires approximately 638 megabytes of computer storage and is available at https://pubs.er.usgs.gov/ publication/wri034064/. To install the database, the file "scour.mdb" should be copied from the Web site to a directory of the user's choice. After copying this file to the computer, the properties of the file should be changed from "Read-only" by (1) right clicking on the file and selecting "Properties" on the popup menu, (2) unselecting the "Read-only" option in the Properties menu box, and then (3) clicking "OK" at the bottom of the menu box. To invoke the SCBSD, the file "scour.mdb" should be opened in Access. Upon opening this file, a menu box titled, "Bridge-Scour Data Reports," will appear. This menu box lists the 10 automated reports described in appendix A and allows the user to generate the automated reports for a selected bridge. Near the top of this menu box is a drop-down menu designated by a menu button with a downward pointing arrowhead. Clicking on this button will produce a list of sites included in this study. From this list, the user should select a bridge of interest. Once a specific bridge has been selected, the user can view the various automated reports, for the bridge of interest, by selecting the "View Selected Record" menu button that is to the right of the report of interest. Selecting the "View All Reports" menu button will generate, in numeric order, the corresponding report for all bridges.

The SCBSD is a valuable tool for use in investigating clear-water abutment scour and contraction scour. For one who is assessing scour at bridges in South Carolina, the SCBSD provides a tool for making site comparisons. Sites under investigation, but not included in the current study, can be compared with sites in the SCBSD to gain insights about the range of anticipated scour depths. The SCBSD also provides a source of data to assess various theoretical methods for predicting clear-water abutment and contraction scour. Most equations for predicting scour are driven by hydraulic variables, such as flow depth and velocity. These variables can be extracted from the SCBSD and used in various theoretical equations to compute theoretical scour depths. The theoretical scour depths can then be compared with observed scour, as well as the field-data envelope curves, to assess the chosen equation's performance. (Hydraulic data in the SCBSD may need to be manipulated to obtain specific variables required for a given theoretical equation.)

One should keep in mind that the hydraulic data in the SCBSD were generated from a model and, therefore, do not necessarily represent the flow conditions that created the observed scour. As a result, some error is likely to be introduced into the comparison of theoretical scour with observed scour because of inaccuracies in the hydraulic data. However, the abundance of data points in the SCBSD will allow such comparisons to show the general trends of a theoretical equation and will provide some indication of the equation's performance.

The SCBSD provides only limited information at each study site and, therefore, cannot be relied upon to provide a complete understanding of the sites. If more detailed information is required to understand conditions at a given site, then other data sources, such as topographic maps and bridge plans, should be consulted. Under certain circumstances, site visits may be required to gain a full appreciation of the observed scour and the conditions that created it. 


\section{SUMMARY}

Observations of clear-water abutment scour and clear-water contraction scour at 146 bridges in the Piedmont and Coastal Plain of South Carolina were collected by the U.S. Geological Survey, in cooperation with the South Carolina Department of Transportation. The 209 observations of clear-water abutment-scour depth ranged from 0 to 23.6 feet, and the 76 observations of clear-water contraction-scour depth in the Piedmont ranged from 0 to 4.5 feet. The collected scour data represent the maximum clear-water abutment- and (or) clear-water contraction-scour depth that has occurred at a given bridge since construction. Although flow conditions creating the observed scour are not known for most sites, evidence suggests that approximately 80 percent of the bridges may have experienced at least one event equaling or exceeding the 25-year flow. Thirty-five of these sites have documented maximum historic flows exceeding the 20-year flow, with 24 sites having flows exceeding the 100-year flow magnitude. Because the collected data encompasses a number of sites that have experienced relatively large flows, the data should provide a reasonable range for anticipated scour depths at bridges with similar site characteristics.

To gain insights into hydraulic conditions that may have created the observed scour, hydraulic models were developed for each site using the one-dimensional step-backwater model, WSPRO. Because the magnitude of large floods was unknown at most sites, the 100 -year flow was modeled as a common flood. In addition, known maximum historic flows were modeled at 35 sites. Hydraulic data generated from the WSPRO model were used to compute theoretical-scour with methods presented in HEC-18. A comparison of theoretical and observed scour showed that theoretical abutment- and contraction-scour depths generally exceeded the observed scour depths and often times were excessive.

Modeled hydraulic data, theoretical scour data, and field data were compiled into a database and were used to investigate relations that may help explain scour in South Carolina. Abutment-scour field data were compared with dimensionless relations for laboratory data. This comparison showed that the range of dimensionless variables used in laboratory investigations was often outside the range of the dimensionless variables for field data in South Carolina. This implies that abutmentscour relations derived from laboratory data may not be applicable to field conditions in South Carolina.
Variables determined to be influential in creating abutment scour within laboratory studies were investigated to understand their influence within the South Carolina field data. Many of these variables appeared to be insignificant under field conditions found in South Carolina. The strongest explanatory variables for abutment scour appeared to be embankment length, geometric-contraction ratio, approach velocity, and soil cohesion.

The investigation identified several envelope curves within the field data that could be used for assessing reasonable ranges of abutment-scour depth in South Carolina. These envelope curves include embankment length and the geometric-contraction ratio as the primary explanatory variable. The envelope curves show that abutment-scour depth increases as these explanatory variables increase. The envelope curves are simple to apply and are an improvement over the current methods for predicting theoretical abutment scour in South Carolina.

Observed contraction-scour depths on the overbanks of the Piedmont were relatively small. The concept of permissible flow velocity was used to help understand and explain this phenomenon. Previous studies indicate that cohesive soils, similar to those of Piedmont overbanks, can sustain flow velocities in the range of 3 to 5 feet per second without experiencing significant erosion. Approximately 60 percent of the clear-water contraction-scour observations have modeled overbank-flow velocities less than 3.5 feet per second with only five observations ( 7 percent) having flow velocities exceeding 5 feet per second. Based on this observation, significant erosion on Piedmont overbanks should not be anticipated. This is consistent with the minimal scour depths observed in the field, and indicates that the concept of permissible velocity may be useful as a qualitative indicator for assessing the potential for contraction scour on Piedmont overbanks.

The investigation also identified an envelope within the field data that could be used for assessing reasonable ranges of clear-water contraction-scour depths in the Piedmont of South Carolina. The envelope includes the geometric-contraction ratio as the primary explanatory variable. The envelope shows that clear-water contraction-scour depth increases as this ratio increases and eventually reaches a limit of about 4.5 feet. The envelope is simple to apply and is an improvement over the current methods for predicting theoretical clear-water contraction scour on overbanks in the Piedmont of South Carolina. 
Although the methods presented show considerable improvement over existing theoretical methods for predicting scour in South Carolina, the limitations of these empirical methods are important. The methods should not be used outside the range of data for which they were developed and special consideration is required for sites with bends directly upstream from the bridge or at sites with a high potential for channel widening. These methods also do not consider the washout of road embankments, which is a common problem in South Carolina.

Data for each bridge site have been compiled into a database that includes photographs, figures, observed scour depths, theoretical scour depths, limited basin characteristics, limited soil data, and theoretical hydraulic data. The database can be used to compare studied sites with unstudied sites in order to assess the potential for scour at the unstudied sites. In addition, the database provides a large source of field data that can be used to assess the performance of various theoretical methods for predicting clear-water abutment and contraction scour.

\section{SELECTED REFERENCES}

Bedient, P.B., and Huber, W.C., 1988, Hydrology and floodplain analysis: Reading, Mass., Addison-Wesley Publishing Co., 650 p.

Bohman, L.R., 1990, Determination of flood hydrographs for streams in South Carolina: Volume 1. Simulation of flood hydrographs for rural watersheds in South Carolina: U.S. Geological Survey Water-Resources Investigations Report 89-4087, 53 p.

1992, Determination of flood hydrographs for streams in South Carolina: Volume 2. Estimation of peak-discharge frequency, runoff volumes, and flood hydrographs for urban watersheds: U.S. Geological Survey Water-Resources Investigations Report 92-4040, $79 \mathrm{p}$.

Das, B.P., 1973, Bed scour at end-dump channel constrictions: Journal of the Hydraulics Division, American Society of Civil Engineers, v. 99, no. HY12, Paper no.10228, p. 2273-2291.

Dongol, D.M.S., 1993, Local scour at bridge abutments: University of Auckland, New Zealand, School of Engineering Report no. 544, 410 p.

Fortier, Samuel, and Scobey, F.C., 1926, Permissible canal velocities: Transactions of the American Society of Civil Engineers, v. 89, no. 1588, p. 940-984.
Froehlich, D.C., 1989, Local scour at bridge abutments: Hydraulic Engineering, Proceedings of the 1989 National Conference on Hydraulic Engineering: New York, American Society of Civil Engineering, p. 13-18.

Gerhart, P.M., Gross, R.J., and Hochstein, J.I., 1992, Fundamentals of Fluid Mechanics (2d ed.): Reading, Mass., Addison-Wesley Publishing Co., 983 p.

Guimaraes, W.B, and Bohman, L.R., 1992, Techniques for estimating magnitude and frequency of floods in South Carolina, 1988: U.S. Geological Survey WaterResources Investigations Report 91-4157, 174 p.

Gunter, H.C., Mason, R.R., and Stamey, T.C., 1987, Magnitude and frequency of floods in rural and urban basins of North Carolina: U.S. Geological Survey WaterResources-Investigations Report 87-4096, 52 p.

Hurley Jr., N.M., 1996, Assessment of scour-critical data collected at selected bridges and culverts in South Carolina, 1990-92: U.S. Geological Survey Open-File Report 96-350, 119 p.

Kandasamy, J.K., 1985, Local scour at skewed abutments: University of Auckland, New Zealand, School of Engineering Report no. 375 as cited in Dongol, 1993.

Keown, M.P., Oswalt N.P., Perry, E.B., and Dordeau Jr., E.A., 1977, Literature survey and preliminary evaluation of streambank protection methods: U.S. Army Corps of Engineers, Waterways Experiment Station, Technical Report H-79-9.

Kwan, T.F., 1984, Study of abutment scour: University of Auckland, New Zealand, School of Engineering Report no. 328 as cited in Dongol, 1993.

Lagasse, P.F., Schall, J.D., Johnson, F., Richardson, E.V., Richardson, J.R., and Chang, F., 1991, Stream stability at highway structures: Federal Highway Administration Hydraulic Engineering Circular No. 20, Publication FHWA-IP-90-014, 195 p.

Laursen, E.M., 1960, Scour at bridge crossings: Journal Hydraulic Division, American Society of Civil Engineering, v. 89, no. HY3.

1963, An analysis of relief bridge scour: Journal Hydraulic Division, American Society of Civil Engineering, v. 92, no. HY3.

Melville, B.W., 1992, Local scour at bridge abutments: Journal of Hydraulic Engineering, American Society of Civil Engineering, v. 118, no. 4, p. 615-630.

Melville, B.W. and Coleman, S.E., 2000, Bridge Scour: Highlands, Colorado, Water Resources Publications, LLC, 550 p.

Melville, B.W., and Sutherland, A.J., 1988, Design method for local scour at bridge piers: Journal of Hydraulic Engineering, American Society of Civil Engineers, v. 114 , no. 10 , p. $1210-1226$.

Raudkivi, A.J., and Sutherland, A.J., 1981, Scour at bridge crossings: Wellington, New Zealand, National Roads Board, Road Research Unit, Report No. 51. 
Richardson, E.V., and Davis, S.R., 1995, Evaluating scour at bridges: Federal Highway Administration Hydraulic Engineering Circular No. 18, Publication FHWA-IP90-017, 204 p.

Richardson, E.V., Harrison, L.J, and Davis, S.R., 1991, Evaluating scour at bridges: Federal Highway Administration Hydraulic Engineering Circular No. 18, Publication FHWA-IP-90-017, 105 p.

Richardson, E.V., Harrison, L.J., Richardson, J.R., and Davis, S.R., 1993, Evaluating scour at bridges: Federal Highway Administration Hydraulic Engineering Circular No. 18, Publication FHWA-IP-90-017, 131 p.

Richardson, E.V., and Richardson, J. R., 1992, Discussion of Melville, B.W., 1992 Local Scour at Bridge Abutments, submitted to American Society of Civil Engineers, Journal of Hydraulics Division.

Richardson, E.V., Simons, D.B., and Julien, P.Y., 1990, Highways in the river environment participant notebook: Federal Highway Administration, Publication FHWA-HI-90-016, 650 p.

Rouse, Hunter, 1946, Elementary mechanics of fluids: New York, Wiley and Sons, $376 \mathrm{p}$.

Shearman, J.O., 1990, User's manual for WSPRO-A computer model for water-surface profile computations: Federal Highway Administration, Report no. FHWA-IP89-027, 175 p.

Simons, Li, and Associates, 1982, Engineering analysis of fluvial systems: p. 54.

South Carolina DOQQ Archive, 1994, Longs-SC-SW, digital orthophoto quarter quadrangle, web address: http://water3.dnr.state.sc.us/sidserver/bin/show_jpg.pl? dir $=W \& c l i e n t=$ sample $\&$ image $=$ Longs - SCNCSE.sid\&size $=1 \&$ indexFg $=2$.
U.S. Geological Survey, 1969, Whitmire South, S.C., quadrangle: U.S. Geological Survey 7.5-minute series topographic map, scale 1:24,000.

1971, Clinton, S.C., quadrangle: U.S. Geological Survey 7.5-minute series topographic map, scale $1: 24,000$.

1983, Lockhart, S.C., quadrangle: U.S. Geological Survey 7.5-minute series topographic map, scale $1: 24,000$.

1990, Longs, S.C., quadrangle: U.S. Geological Survey 7.5-minute series topographic map, scale 1:24,000.

Vanoni, V.A., 1977, Sedimentation Engineering, American Society of Civil Engineers Task Committee for the Preparation of the Manual on Sedimentation of the Sedimentation Committee of the Hydraulics Division.

Yakoub, N.G.R., 1995, Effect of cohesion on bridge abutment scour: Colorado State University, Civil Engineering Department, dissertation, $231 \mathrm{p}$.

Yang, T.Y., 1996, Sediment transport theory and practice: New York, McGraw-Hill, 396 p.

Zalants, M.G., 1990, Low-flow characteristics of natural streams in the Blue Ridge, Piedmont, and upper Coastal Plain physiographic provinces of South Carolina: U.S. Geological Survey Water-Resources Investigations Report 90-4188, 92 p.

1991, Low-flow frequency and flow duration of selected South Carolina streams through 1987: U.S. Geological Survey Water-Resources Investigations Report 91-4170, 87 p. 


\section{APPENDIX A}

Explanation of Variables in the South Carolina Bridge-Scour Database 
Data for this project have been compiled into a database, including photographs, figures, observed scour depths, theoretical scour depths, limited basin characteristics, limited soil data, and theoretical hydraulic data and can be viewed using Microsoft Access ${ }^{1}$. The South Carolina Bridge Scour Database (SCBSD) provides automated report formats that can be used to view data for a given site. The raw data also can be viewed in tabular format. Although most data for a given site can be viewed through the report formats, some data can only be viewed in the raw data tables. Blank data entries that appear in the reports or raw data tables indicate that data are not applicable or are missing. Following is a list and brief description of the automated report formats that are in the SCBSD.

\section{(1) Information Report}

- includes site location information, bridge length, construction history, bridge age, drainage area, and channel slope.

\section{(2) Abutment Scour Report}

- includes theoretical abutment-scour depths computed with the Froehlich (1989) equation and the variables used to compute those depths; hydraulic variables in this report were estimated with the Water-Surface Profile (WSPRO) model (Shearman, 1990).

\section{(3) Clay Information Report}

- includes selected grain-size data for the second set of soil samples obtained at all Piedmont sites and at nine Coastal Plain sites; the second set of samples were collected to better define the percent of clays and silts at the selected sites.

\section{(4) Clearwater Scour Report}

- includes theoretical clear-water contraction scour depths computed with the Laursen (1963) equation and the variables used to compute those depths; hydraulic variables in this report were estimated with the WSPRO model (Shearman, 1990).

\section{(5) Field Information Report}

- includes selected scour-hole dimensions, observed infill depths, median grain size based on the initial soil samples, and general soil type at the site.

\section{(6) Livebed Scour Report}

- includes theoretical live-bed contraction-scour depths computed with the modified Laursen (1960) equation presented in HEC-18 (Richardson and Davis, 1995) and the variables used to compute those depths; live-bed scour was computed only at sites with significant lowflow channels; hydraulic variables in this report were estimated with the WSPRO model (Shearman, 1990).

\section{(7) Pier Scour Report}

- includes theoretical pier-scour depths computed with the HEC-18 (Richardson and Davis, 1995) pier scour equation and the variables used to compute those depths; only limited theoretical pier-scour data are included in the SCBSD as described in the "Theoretical Pier

${ }^{1}$ Any use of trade, product, or firm names is for descriptive purposes only and does not imply endorsement by the U.S. Government. 
Scour" section of the report; hydraulic variables in this report were estimated with the WSPRO model (Shearman, 1990).

\section{(8) Wspro Report}

- includes selected hydraulic variables computed with the WSPRO model (Shearman, 1990).

(9) Photos

- includes photographs and captions for most sites.

(10) Scour Figures

- includes scour contour plots for 80 sites (primarily located in the Coastal Plain).

There are eight raw data tables in the SCBSD; a brief description of each table and the associated variables follows. The headings for the following sections correspond with the table names in the database and are listed in alphabetical order. It should be kept in mind that hydraulic variables in the database are estimates obtained from the WSPRO (Shearman, 1990) model and errors could exist within these estimates.

\section{Abutment_Scour Table}

Theoretical abutment-scour depths and the variables used to compute those depths are stored in this table. Theoretical scour was computed for the 100-year flow, index flow, and the maximum historic flow when available. Scour depths were computed using the Froehlich (1989) and the Highways in the River Environment (HIRE) (Richardson and others, 1990) equations as presented in HEC-18 (Richardson and Davis, 1995). For more details about the computation of abutment scour, refer to the "Theoretical Abutment Scour" section of the report. The variables in the database table are briefly defined below:

\author{
bridgeno \\ abut_qtype \\ abut_location \\ abut_blocked cfs \\ abut_blocked area \\ abut_blocked length \\ abut_flowdepth \\ abut_blocked flowdepth \\ abut_skew
}

abut_tube flowvel

abut_blocked flowvel

abut_k1

abut_k2

abut_froel froude
South Carolina Department of Transportation (SCDOT) bridge identification number identifies the flow used in the theoretical computation as the 100-year flow (Q100), the index flow (QAGE), or the maximum historic flow (QHIS)

identifies abutment location as either the left or right abutment as determined by an observer looking downstream

approach flow obstructed by the embankment, in cubic feet per second $\left(\mathrm{ft}^{3} / \mathrm{s}\right)$

approach flow area obstructed by embankment, in square feet $\left(\mathrm{ft}^{2}\right)$

length of embankment blocking flow, in feet (ft)

flow depth directly at abutment toe, in $\mathrm{ft}$

average approach flow depth obstructed by the embankment, in $\mathrm{ft}$

skew of embankment to flow, in degrees;

positive skews indicate the embankment points upstream;

negative skews indicate the embankment points downstream

flow velocity at abutment toe determined from the WSPRO stream tube located at the bridge abutment in the bridge cross section, in feet per second (ft/s)

average approach flow velocity obstructed by the embankment, in $\mathrm{ft} / \mathrm{s}$

coefficient for abutment type

coefficient for embankment skew

Froude number for the approach flow obstructed by the embankment 
abut_froel scourdepth

abut_scourdepth wo

abut_hire froude

abut_hire scourdepth

abut_type theoretical abutment-scour depth computed using the Froehlich (1989) equation, including safety factor

theoretical abutment-scour depth computed using the Froehlich (1989) equation, but without safety factor

Froude number for HIRE (Richardson and others, 1990) equation

theoretical abutment-scour depth computed using the HIRE (Richardson and others, 1990) equation

identification of abutment type (spill through or vertical)

\section{Bridge Info Table}

This table provides basic site information including bridge identification, location, limited basin characteristics data, construction dates, SCDOT bridge-plan file numbers, and bridge age. The variables are defined below:

bridgeno

county

long

lat

province

road

stream

drainagearea

channel_slope

bridgelength

bridgeconstdate

bridgeplannumber

widened

widendate

widenplannumber

bridgeage

oldbridge

oldbridgedata
SCDOT bridge identification number

county in which the bridge is located

longitude of bridge, in degrees, minutes, seconds

latitude of bridge, in degrees, minutes, seconds

physiographic province in which the bridge is located

road type and number

name of stream

drainage area at bridge, in square miles $\left(\mathrm{mi}^{2}\right)$

channel slope at the bridge as determined from U.S. Geological Survey (USGS) 7.5minute series topographic map, in feet per foot $(\mathrm{ft} / \mathrm{ft})$

bridge length, in $\mathrm{ft}$

calendar year in which bridge was originally constructed

SCDOT road plans file number from which construction date was estimated

indicates if bridge has been widened since original construction date

calendar year when bridge was widened

SCDOT road plans file number from which widening date was estimated

age of bridge in 1996; if bridge was widened, an attempt was made to assess if the construction at the time of widening disturbed the area of scour; if the assessment indicated that the area of scour was disturbed, the age was based on the widening date; otherwise the age was based on the original construction date

indicates if an old bridge was in place (but removed) at the time of the original construction of the existing bridge

calendar year in which the old structure was constructed 


\section{Clay Information Table}

This table provides data for the second set of soil samples obtained to better define the percent of clays and silts at all Piedmont sites and at nine Coastal Plain sites that were noted to have clayey surface soils. The median grain size $\left(D_{50}\right)$ in the second set of samples often varies from the $D_{50}$ of the original sample. This in part is attributed to the heterogeneous nature of the soils, and indicates that all soil data in this report should be viewed with caution. This table also includes original soil sample data from the 1999 flood sites along the Waccamaw, Pee Dee, and Little Pee Dee Rivers. The variables in the database table are briefly defined below:

bridgeno SCDOT bridge identification number

clay_50mm the $\mathrm{D}_{50}$ for the second sediment sample, in millimeters $(\mathrm{mm})$

percentfiner_0625 the percent finer than $0.0625 \mathrm{~mm}$ by weight in the second sediment sample

percentfiner_004 the percent finer than $0.004 \mathrm{~mm}$ by weight in the second sediment sample

\section{Clearwater_Scour Table}

Theoretical clear-water contraction-scour depths and the variables used to compute those depths are stored in this table. Theoretical scour was computed for the 100-year flow, index flow, and the maximum historic flow when available. Scour depths were computed using the Laursen (1963) clear-water contraction-scour equation as presented in HEC-18 (Richardson and Davis, 1995). For more details about the computation of clear-water contraction scour refer to the "Theoretical Clear-Water Contraction Scour" section of the report. The variables in the database table are briefly defined below:

bridgeno
cw_qtype
cw_location
cw_scourdepth
cw_scourdepth_minuspiers
cw_cfs
cw_width
cw_flowdepth
cw_d50mm

cw_cum_pierwidth
SCDOT bridge identification number

identifies the flow used in the theoretical computation as either the 100-year flow (Q100), the index flow (QAGE), or the maximum historic flow (QHIS)

identifies overbank location as either the left or right overbank as determined by an observer looking downstream or as a swampy channel with no well-defined low-flow channel

theoretical clear-water contraction-scour depth computed using the Laursen (1963) equation and not subtracting the cumulative pier width from the contracted width, in $\mathrm{ft}$

theoretical clear-water contraction-scour depth computed using the Laursen (1963) equation and subtracting the cumulative pier width from the contracted width, in $\mathrm{ft}$

flow in the contracted section, in $\mathrm{ft}^{3} / \mathrm{s}$

width of contracted section, in $\mathrm{ft}$

average flow depth at the contracted section, in $\mathrm{ft}$

the $\mathrm{D}_{50}$ based on the original soil sample at each site; for sites with a $\mathrm{D}_{50}$ less than $0.062 \mathrm{~mm}$, the $\mathrm{D}_{50}$, was set to $0.062 \mathrm{~mm}$; for additional information on these soils, refer to the Clay Information Table

the cumulative pier width within the contracted section, in $\mathrm{ft}$ 


\section{Field_Observations Table}

This table provides field data collected at each site, including scour-hole geometry and soil data for the original soil sample. The variables are defined below:

$$
\begin{aligned}
& \text { bridgeno } \\
& \text { obs_location }
\end{aligned}
$$

scourdepth_floodpn

scourdepth_channel

dataqual_of_scourdepth

infill

dataqual_of_infill

pierexistence

piershape

pierwidth

dist_bridgecenterline_to_hole

dist_to_leftedgeofhole

dist_to_scourlowpt

dist_to_rightedgeofhole

scourwidth

scourlength

soiltype_unscour
SCDOT bridge identification number

identifies the location where the scour hole was observed; the left and right overbank or abutment is determined by an observer looking downstream; a swampy channel, in general, refers to shorter bridges ( $240 \mathrm{ft}$ or less) with a single large scour hole developing at the site rather than individual left and (or) right abutment scour hole scour depth referenced to the average floodplain elevation in the region of the observed scour, in $\mathrm{ft}$

scour depth referenced to the average channel bed elevation in the region of the observed scour, in $\mathrm{ft}$

This situation often occurs at swampy sites with shorter bridges, where a shallow channel runs through the scoured region; these data were not used in the analysis of this report but are provided here for information.

subjective indicator of the quality of the measured scour

the amount of infill at the low point of the scour hole, in $\mathrm{ft}$

subjective indicator of the quality of the measured infill

indicator of existing pier at the low point of the scour hole

shape of the pier at the low point of the scour hole

width of the pier at the low point of the scour hole, in $\mathrm{ft}$

the upstream or downstream distance from the low point of the scour hole to the roadway centerline, in $\mathrm{ft}$;

Negative numbers are downstream from the roadway centerline and positive numbers are upstream; refer to the "Scour Hole Longitudinal Location" section of this report for more details.

distance from the left edge of the scour hole to the abutment toe as determined by an observer looking downstream, in $\mathrm{ft}$

Refer to the "Lateral Reference for Scour Hole" section of this report for more details.

distance from the low point of the scour hole to the abutment toe as determined by an observer looking downstream, in $\mathrm{ft}$

distance from the right edge of the scour hole to the abutment toe as determined by an observer looking downstream, in $\mathrm{ft}$

Refer to the "Lateral Reference for Scour Hole" section of this report for more details.

top width at the low point of the scour hole, in $\mathrm{ft}$

Refer to the "Scour Hole Top Width" section of this report for more details.

the longitudinal length of the scour hole, in $\mathrm{ft}$

a subjective indicator of the general surface soils in the unscoured region of the observed scour; this information is not necessarily an indicator of the measured grain size and should be viewed with caution; the information can be used to determine if there is a difference between the surface soils and the soils at the bottom of the scour hole; following is a description of each class: 
- clay - a relatively cohesive soil

- sand - a sandy soil with relatively low cohesion

- layered - alternating layers of clay and sand

- mix - a mixture of sand and clay

<comment_d50mm_unscour

indicator if the $\mathrm{D}_{50}$ is less than $0.0625 \mathrm{~mm}$, but was assumed to be $0.0625 \mathrm{~mm}$, because the grain-size analysis of the original soil samples did not go below $0.0625 \mathrm{~mm}$

d50mm_unscour

soiltype_scour

formation

<comment_d50mm_hole

d50mm_hole

wide_enough_scour the median grain size, $\mathrm{D}_{50}$, of the original sediment sample, in $\mathrm{mm}$

a subjective indicator of the general soils at the low point of the scour hole; this information is not necessarily an indicator of the measured grain size and should be viewed with caution; the information can be used to determine if there is a difference between the surface soils and the soils at the bottom of the scour hole; following is a description of each class:

- clay - a relatively cohesive soil

- sand - a sandy soil with relatively low cohesion

- layered - alternating layers of clay and sand

- mix - a mixture of sand and clay

a subjective judgment that indicates if the soil at the bottom of the scour hole is a material from an older geologic formation in contrast to the newer surface alluviums; this is more common in the Coastal Plain where scour initially removes the sandy soils and then cuts into an older geologic formation; the soil characteristics of the formation are distinctly different from the surface alluviums and is often a clayey soil

indicator if the $\mathrm{D}_{50}$ is less than $0.0625 \mathrm{~mm}$, but was assumed to be $0.0625 \mathrm{~mm}$, because the grain-size analysis of the original soil samples did not go below 0.0625 $\mathrm{mm}$

the median grain size, $\mathrm{D}_{50}$, of the original sediment sample, in $\mathrm{mm}$

indicator if abutment scour hole encompasses most of overbank area precluding the development of a separate clear-water contraction scour hole.

\section{Livebed_Scour Table}

Theoretical live-bed contraction-scour depths and the variables used to compute those depths are stored in this table. Theoretical scour was computed for the 100-year flow, index flow, and the maximum historic flow when available. Scour depths were computed using a modified version of the Laursen (1960) live-bed-scour equation as presented in HEC-18 (Richardson and Davis, 1995). For more details about the computation of livebed contraction scour, refer to the "Theoretical Live-Bed Contraction Scour" section of the report. The variables in the database table are briefly defined below:

bridgeno

cw_qtype
SCDOT bridge identification number

identifies the flow used in the theoretical computation as either the 100-year flow (Q100), the index flow (QAGE), or the maximum historic flow (QHIS) 
lb_scourdepth

lb_flowdepth_approach

lb_cfs_approach

lb_width_approach

lb_cfs_bridge

lb_width_bridge

lb_eslope

lb_d50mm

lb d50mm fallvel theoretical live-bed contraction-scour depth computed using the modified Laursen (1960) equation presented in HEC-18 (Richardson and Davis, 1995), in ft

average flow depth in the approach channel, in $\mathrm{ft}$

flow in the approach channel, in $\mathrm{ft}^{3} / \mathrm{s}$

bank-to-bank top width at approach channel, in $\mathrm{ft}$

flow in the bridge channel, in $\mathrm{ft}^{3} / \mathrm{s}$

bank-to-bank top width at bridge channel, in $\mathrm{ft}$

slope of the energy grade line between the approach and bridge cross section, in $\mathrm{ft} / \mathrm{ft}$

the $\mathrm{D}_{50}$ in the live-bed channel, in $\mathrm{mm}$; in most cases these data were obtained from level 2 bridge-scour studies; when this information was not available, a grab sample from the channel was obtained and analyzed for grain-size distribution

the fall velocity for the $\mathrm{D}_{50}$, in $\mathrm{ft} / \mathrm{s}$

\section{Pier_Scour Table}

Theoretical pier-scour depths and the variables used to compute those depths are stored in this table.

Theoretical scour was computed for the 100-year flow, index flow, and the maximum historic flow when available. Scour depths were computed using the HEC-18 pier-scour equation (Richardson and Davis, 1995). Only limited theoretical pier-scour data are included in the database. For more details about the computation of pier scour and the data included in the database, refer to the "Theoretical Pier Scour" section of the report. The variables in the database table are briefly defined below:

$\begin{array}{ll}\text { bridgeno } & \begin{array}{l}\text { SCDOT bridge identification number } \\ \text { pier_qtype }\end{array} \\ \text { identifies the flow used in the theoretical computation as } \\ \text { pier_location } \\ \text { pier_scourdepth } \\ \text { identifies the general location of the pier within the brid } \\ \text { theoretical pier-scour depth computed using the HEC-18 } \\ \text { (Rier_flowdepth } \\ \text { pier_flowvel } \\ \text { pier_width } \\ \text { average approach flow depth at the pier, in } \mathrm{ft}\end{array}$




\section{WSPRO_Scour Table}

This table provides hydraulic data estimated with the WSPRO (Shearman, 1990) model for various flow conditions, including the 100-year flow, the index flow, and the maximum historic flow when available. Hydraulic data for pre- and post-scour conditions are included for bridge sites with relatively deep scour holes (approximately $4 \mathrm{ft}$ or greater). The names of the hydraulic variables in this table are, in most cases, identical to the variables in the WSPRO manual. For more details about the variables refer to the WSPRO manual (Shearman, 1990). For more details on the approach for developing the models in this study refer to the "Estimating Hydraulic Data" section of this report. The variables in the database table are briefly defined below:

bridgeno

wspro_condition

wspro_qtype

wspro_crosssection

lew

area

vhd

hf

egl

crws

q

wsel

flen

rew

$\mathrm{k}$

alph

ho

fr

vel

type

ppcd

flow

c

pa

lsel

$\mathrm{mg}$

$\mathrm{mk}$

$\mathrm{kq}$

$\mathrm{xlkq}$

xrkq
SCDOT bridge identification number

identifies the model data as pre-scour or post scour condition

identifies the flow used in the model as either the 100-year flow (Q100), the index flow (QAGE), or the maximum historic flow (QHIS)

identifies the cross section for the given hydraulic data

station for left edge of water, in $\mathrm{ft}$

cross-section flow area, in $\mathrm{ft}^{2}$

cross-section velocity head, in $\mathrm{ft}$

friction loss, in $\mathrm{ft}$

energy grade line elevation, in $\mathrm{ft}$

critical water-surface elevation, in $\mathrm{ft}$

flow, in $\mathrm{ft}^{3} / \mathrm{s}$

computed or assumed water-surface elevation, in $\mathrm{ft}$

effective flow length from approach to bridge, in $\mathrm{ft}$

station for right edge of water, in $\mathrm{ft}$

cross-section conveyance

velocity head correction factor for uniform velocity distribution

other losses, in $\mathrm{ft}$

Froude number

flow velocity, in $\mathrm{ft} / \mathrm{s}$

type of bridge opening

code to distinguish between piers and piles

indicates flow class for bridge

coefficient of discharge for bridge opening

ratio of pier (pile) area to gross area in the bridge opening

test value for low-chord elevation in a bridge used to test for possible pressure flow geometric-contraction ratio

conveyance-contraction ratio

conveyance of $\mathrm{Kq}$ segment of the approach cross section

left station of $\mathrm{Kq}$ section

right station of $\mathrm{Kq}$ section 


\section{Selected References}

Froehlich, D.C., 1989, Local scour at bridge abutments: Hydraulic Engineering, in Proceedings of the 1989

National Conference on Hydraulic Engineering: New York, American Society of Civil Engineering, p. 13-18.

Laursen, E.M., 1960, Scour at bridge crossings: Journal Hydraulic Division, American Society of Civil Engineering, v. 89, no. HY3.

1963, An analysis of relief bridge scour: Journal Hydraulic Division, American Society of Civil Engineering, v. 92, no. HY3.

Richardson, E.V., and Davis, S.R., 1995, Evaluating scour at bridges: Federal Highway Administration Hydraulic Engineering Circular No. 18, Publication FHWA-IP-90-017, 204 p.

Richardson, E.V., Simons, D.B., and Julien, P.Y., 1990, Highways in the river environment participant notebook: Federal Highway Administration, Publication FHWA-HI-90-016, 650 p.

Shearman, J.O., 1990, User's manual for WSPRO_A computer model for water-surface profile computations: Federal Highway Administration, Report no. FHWA-IP-89-027, 175 p. 


\section{APPENDIX B}

South Carolina Bidge-Scour Study Sites and Reference Numbers for Figures 1, 5, and 6

[At twin bridge crossings only the structure number for the North or East bound bridge is provided. S.C., South Carolina Route; I-, Interstate Highway; U.S., United States Route; S-, Secondary Road] 
Appendix B. South Carolina bridge-scour study sites and reference numbers for figures 1, 5, and 6

\begin{tabular}{|c|c|c|c|c|}
\hline $\begin{array}{c}\text { Reference } \\
\text { number for } \\
\text { figures } 1,5, \text { and } 6\end{array}$ & County & Road & Stream & Structure number \\
\hline 1 & Abbeville & S.C. 201 & Little River & 014020100300 \\
\hline 2 & Aiken & $\mathrm{I}-20$ & South Edisto River & 021002021200 \\
\hline 3 & Allendale & U.S. 301 & Salkehatchie River & 032030100600 \\
\hline 4 & Allendale & U.S. 301 & Salkehatchie River & 032030100700 \\
\hline 5 & Allendale & S.C. 3 & King Creek & 034000300100 \\
\hline 6 & Allendale & S.C. 3 & Gaul Creek & 034000300200 \\
\hline 7 & Allendale & $\mathrm{S}-21$ & Coosawhatchie River & 037002100100 \\
\hline 8 & Allendale & S-107 & Gaul Branch & 037010700100 \\
\hline 9 & Anderson & $\mathrm{I}-85$ & Brushy Creek & 041008511200 \\
\hline 10 & Anderson & S-263 & Rocky River & 047026300100 \\
\hline 11 & Calhoun & U.S. 176 & Flea Bite Creek & 092017600400 \\
\hline 12 & Cherokee & S.C. 5 & Buffalo Creek & 114000500200 \\
\hline 13 & Cherokee & S-348 & Buffalo Creek & 117034800100 \\
\hline 14 & Chester & $\mathrm{I}-77$ & Fishing Creek & 121007710700 \\
\hline 15 & Chester & S.C. 9 & Turkey Creek & 124000900200 \\
\hline 16 & Chester & S.C. 9 & Fishing Creek & 124000901100 \\
\hline 17 & Chester & S.C. 72 & Sandy River & 124007200200 \\
\hline 18 & Chester & S.C. 97 & Turkey Creek & 124009700100 \\
\hline 19 & Chester & S.C. 97 & Rocky Creek & 124009700800 \\
\hline 20 & Chester & S.C. 215 & Sandy River & 124021500200 \\
\hline 21 & Chester & S.C. 223 & Fishing Creek & 124022300100 \\
\hline 22 & Chester & S.C. 901 & Rocky Creek & 124090100200 \\
\hline 23 & Chesterfield & S.C. 9 & Thompson Creek & 134000900400 \\
\hline 24 & Chesterfield & S.C. 109 & Thompson Creek & 134010900100 \\
\hline 25 & Clarendon & U.S. 15 & Sammy Swamp & 142001500400 \\
\hline 26 & Clarendon & U.S. 378 & Douglas Swamp & 142037800300 \\
\hline 27 & Clarendon & U.S. 521 & Ox Swamp & 142052100300 \\
\hline 28 & Clarendon & S.C. 261 & Sammy Swamp & 144026100100 \\
\hline 29 & Colleton & U.S. 21 & Sandy Run Creek & 152002100300 \\
\hline 30 & Colleton & S.C. 63 & Deep Creek & 154006300300 \\
\hline 31 & Colleton & S.C. 63 & Little Salkehatchie River & 154006300400 \\
\hline 32 & Colleton & S.C. 63 & Little Salkehatchie River & 154006300500 \\
\hline 33 & Colleton & S.C. 63 & Little Salkehatchie River & 154006300600 \\
\hline 34 & Colleton & S.C. 63 & Little Salkehatchie River & 154006300700 \\
\hline 35 & Colleton & S.C. 64 & Jones Swamp & 154006400700 \\
\hline 36 & Colleton & S.C. 212 & Buckhead Creek & 154021200100 \\
\hline 37 & Colleton & S.C. 212 & Buckhead Creek & 154021200200 \\
\hline 38 & Colleton & S.C. 641 & Willow Swamp & 154064100200 \\
\hline 39 & Dillon & S.C. 41 & Buck Swamp & 174004107100 \\
\hline 40 & Dillon & S.C. 41 & Buck Swamp & 174004107200 \\
\hline
\end{tabular}


Appendix B. South Carolina bridge-scour study sites and reference numbers for figures 1, 5, and 6 (Continued)

\begin{tabular}{|c|c|c|c|c|}
\hline $\begin{array}{c}\text { Reference } \\
\text { number for } \\
\text { figures } 1,5 \text {, and } 6\end{array}$ & County & Road & Stream & Structure number \\
\hline 41 & Dorchester & $\mathrm{I}-26$ & Four Hole Swamp & 181002620300 \\
\hline 42 & Dorchester & U.S. 78 & Cattle Creek & 182007800100 \\
\hline 43 & Dorchester & U.S. 78 & Polk Swamp & 182007800200 \\
\hline 44 & Edgefield & S.C. 230 & Horne Creek & 194023000500 \\
\hline 45 & Fairfield & $\mathrm{I}-77$ & Little Wateree Creek & 201007710600 \\
\hline 46 & Fairfield & $\mathrm{I}-77$ & Big Wateree Creek & 201007710700 \\
\hline 47 & Fairfield & U.S. 21 & Dutchmans Creek & 202002100200 \\
\hline 48 & Fairfield & U.S. 21 & Big Wateree Creek & 202002100400 \\
\hline 49 & Fairfield & S.C. 200 & Wateree Creek & 204020000500 \\
\hline 50 & Florence & $\mathrm{I}-95$ & Lake Swamp & 211009510400 \\
\hline 51 & Florence & $\mathrm{I}-95$ & Pee Dee River & 211009511400 \\
\hline 52 & Florence & U.S. 52 & Lynches Lake & 212005200100 \\
\hline 53 & Florence & U.S. 52 & Jefferies Creek & 212005200700 \\
\hline 54 & Florence & U.S. 76 & Great Pee Dee River & 212007621100 \\
\hline 55 & Florence & U.S. 301 & Douglas Swamp & 212030100100 \\
\hline 56 & Florence & U.S. 301 & Sparrow Swamp & 212030100400 \\
\hline 57 & Florence & U.S. 378 & Big Swamp & 212037801000 \\
\hline 58 & Florence & S.C. 51 & Big Swamp & 214005100200 \\
\hline 59 & Florence & S.C. 51 & Middle Swamp & 214005100400 \\
\hline 60 & Florence & S.C. 51 & Jeffries Creek & 214005100500 \\
\hline 61 & Florence & S.C. 403 & Deep Hole Swamp & 214040300500 \\
\hline 62 & Greenville & S.C. 417 & Horse Pen Creek & 234041700200 \\
\hline 63 & Greenville & S-40 & South Saluda River & 237004000100 \\
\hline 64 & Greenville & S-68 & Reedy River & 237006800100 \\
\hline 65 & Greenville & $\mathrm{S}-125$ & Saluda River & 237012500100 \\
\hline 66 & Greenwood & S.C. 246 & Wilson Creek & 244024600200 \\
\hline 67 & Hampton & U.S. 601 & Coosawhatchie River & 252060100300 \\
\hline 68 & Hampton & S.C. 363 & Coosawhatchie River & 254036300100 \\
\hline 69 & Hampton & S-13 & Whippy Swamp & 257001300500 \\
\hline 70 & Horry & U.S. 501 & Waccamaw River & 262050103100 \\
\hline 71 & Horry & U.S. 501 & Waccamaw River & 262050103200 \\
\hline 72 & Horry & U.S. 501 & Waccamaw River & 262050103300 \\
\hline 73 & Horry & U.S. 501 & Waccamaw River & 262050105200 \\
\hline 74 & Horry & U.S. 501 & Little Pee Dee River & 262050110100 \\
\hline 75 & Horry & S.C. 22 & Waccamaw River & 264002220200 \\
\hline 76 & Horry & S.C. 22 & Waccamaw River & 264002220300 \\
\hline 77 & Horry & S.C. 22 & Waccamaw River & 264002220400 \\
\hline 78 & Jasper & U.S. 278 & Cypress Creek & 272027800100 \\
\hline 79 & Jasper & U.S. 321 & Cypress Swamp & 272032100700 \\
\hline 80 & Jasper & U.S. 321 & Black Swamp Long Branch & 272032100800 \\
\hline
\end{tabular}


Appendix B. South Carolina bridge-scour study sites and reference numbers for figures 1, 5, and 6 (Continued)

\begin{tabular}{|c|c|c|c|c|}
\hline $\begin{array}{c}\text { Reference } \\
\text { number for } \\
\text { figures } 1,5 \text {, and } 6\end{array}$ & County & Road & Stream & Structure number \\
\hline 81 & Jasper & S.C. 3 & Cypress Creek & 274000300200 \\
\hline 82 & Jasper & S.C. 336 & Great Swamp & 274033600100 \\
\hline 83 & Jasper & S-87 & Coosawhatchie River & 277008700100 \\
\hline 84 & Kershaw & U.S. 1 & Little Lynches River & 282000100500 \\
\hline 85 & Kershaw & U.S. 521 & Granneys Quarter Creek & 282052100900 \\
\hline 86 & Kershaw & S.C. 97 & White Oak Creek & 284009700300 \\
\hline 87 & Kershaw & S.C. 97 & Granneys Quarter Creek & 284009700400 \\
\hline 88 & Laurens & S.C. 49 & Enoree River & 304004900400 \\
\hline 89 & Laurens & S.C. 72 & Little River & 304007200500 \\
\hline 90 & Laurens & S.C. 72 & Duncan Creek & 304007201200 \\
\hline 91 & Laurens & S-36 & Reedy River & 307003600200 \\
\hline 92 & Laurens & S-102 & Little River & 307010200100 \\
\hline 93 & Laurens & S-112 & Enoree River & 307011200100 \\
\hline 94 & Laurens & $S-263$ & Enoree River & 307026300100 \\
\hline 95 & Lexington & S.C. 113 & North Edisto River & 324011300100 \\
\hline 96 & McCormick & S.C. 67 & Cuffeytown Creek & 334006700100 \\
\hline 97 & Marion & U.S. 76 & Great Pee Dee River & 342007620100 \\
\hline 98 & Marion & U.S. 501 & Smith Swamp & 342050100300 \\
\hline 99 & Marion & U.S. 501 & Little Pee Dee River & 342050110700 \\
\hline 100 & Marion & U.S. 501 & Little Pee Dee River & 342050110800 \\
\hline 101 & Marion & U.S. 501 & Little Pee Dee River & 342050110900 \\
\hline 102 & Marion & U.S. 501 & Little Pee Dee River & 342050111000 \\
\hline 103 & Marion & U.S. 501 & Little Pee Dee River & 342050111100 \\
\hline 104 & Marion & S.C. 41 & Maiden Down Swamp & 344004100800 \\
\hline 105 & Marion & U.S. 576 & Smith Swamp & 344057620200 \\
\hline 106 & Newberry & U.S. 176 & Indian Creek & 362017600400 \\
\hline 107 & Newberry & U.S. 176 & Kings Creek & 362017600500 \\
\hline 108 & Newberry & S.C. 34 & Little River & 364003400300 \\
\hline 109 & Newberry & S.C. 121 & Saluda River & 364012100101 \\
\hline 110 & Newberry & S-32 & Indian Creek & 367003200200 \\
\hline 111 & Newberry & S-45 & Enoree River & 367004500100 \\
\hline 112 & Newberry & S-81 & Enoree River & 367008100200 \\
\hline 113 & Newberry & S-299 & Cannons Creek & 367029900100 \\
\hline 114 & Oconee & U.S. 76 & Coneross Creek & 372007620500 \\
\hline 115 & Oconee & S.C. 11 & Colonels Fork Creek & 374001100500 \\
\hline 116 & Oconee & S.C. 183 & Coneross Creek & 374018300200 \\
\hline 117 & Orangeburg & U.S. 176 & Providence Swamp & 382017600200 \\
\hline 118 & Orangeburg & U.S. 176 & Providence Swamp & 382017600300 \\
\hline 119 & Orangeburg & U.S. 301 & Four Hole Swamp & 382030110800 \\
\hline 120 & Orangeburg & U.S. 301 & Goodbys Swamp & 382030110900 \\
\hline
\end{tabular}


Appendix B. South Carolina bridge-scour study sites and reference numbers for figures 1, 5, and 6 (Continued)

\begin{tabular}{|c|c|c|c|c|}
\hline $\begin{array}{c}\text { Reference } \\
\text { number for } \\
\text { figures } 1,5 \text {, and } 6\end{array}$ & County & Road & Stream & Structure number \\
\hline 121 & Orangeburg & S.C. 453 & Four Hole Swamp (Br 1) & 384045300200 \\
\hline 122 & Richland & U.S. 321 & Crane Creek & 402032100200 \\
\hline 123 & Saluda & U.S. 378 & Red Bank Creek & 412037800100 \\
\hline 124 & Saluda & U.S. 378 & Little Saluda River & 412037800200 \\
\hline 125 & Spartanburg & U.S. 29 & South Tyger River & 422002900100 \\
\hline 126 & Spartanburg & U.S. 176 & Lawsons Fork Creek & 422017620900 \\
\hline 127 & Spartanburg & S.C. 146 & Enoree River & 424014600100 \\
\hline 128 & Spartanburg & S.C. 296 & Enoree River & 424029600100 \\
\hline 129 & Spartanburg & S-62 & South Tyger River & 427006200500 \\
\hline 130 & Spartanburg & S-118 & Enoree River & 427011800001 \\
\hline 131 & Spartanburg & S-242 & South Tyger River & 427024200200 \\
\hline 132 & Sumter & U.S. 401 & Rock Bluff Creek & 432040100100 \\
\hline 133 & Sumter & U.S. 401 & Rock Bluff Creek & 432040100200 \\
\hline 134 & Union & S.C. 56 & Enoree River & 444005600100 \\
\hline 135 & Union & S-22 & Enoree River & 447002200100 \\
\hline 136 & Williamsburg & S.C. 261 & Paisley Swamp & 454026100300 \\
\hline 137 & Williamsburg & S.C. 261 & Boggy Swamp & 454026100400 \\
\hline 138 & Williamsburg & S.C. 261 & Indiantown Swamp & 454026100500 \\
\hline 139 & Williamsburg & S-16 & Johnson's Creek & 457001600100 \\
\hline 140 & York & S.C. 97 & Bullocks Branch & 464009700300 \\
\hline 141 & York & S.C. 322 & Fishing Creek & 464032200300 \\
\hline 142 & York & S.C. 322 & Tools Fork Creek & 464032200500 \\
\hline 143 & York & S.C. 557 & Crowders Creek & 464055700200 \\
\hline 144 & York & $S-721$ & Taylors Creek & 467072100100 \\
\hline
\end{tabular}

NOTE: The following bridge sites have been excluded from the above list because the area of scour at the bridge was disturbed by construction equipment, bringing the field measurements of scour into question.

$\begin{array}{llll}\text { Allendale } & \text { U..S. } 301 & \text { Salkehatchie River } & 032030100800 \\ \text { Horry } & \text { S.C. } 22 & \text { Waccamaw River } & 264002220100\end{array}$

